Editoras/es

$$
\begin{aligned}
& \text { Erica Conde-V ázquez } \\
& \text { Julia Fontenla-Pedreira } \\
& \text { José Rúas-Araújo }
\end{aligned}
$$

Prólogo: José Rúas-Araújo

\title{
Debates electorales \\ televisados: del antes al después
}

Cuadernos Artesanos de Comunicación / 154
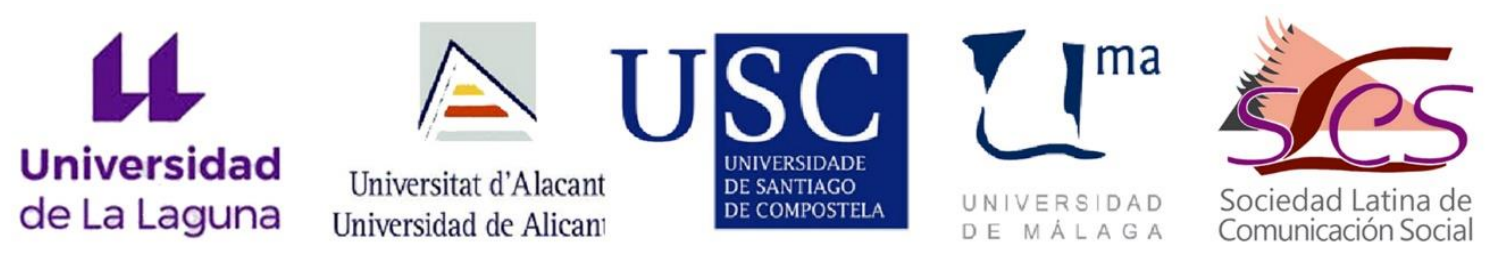


\section{Cuadernos Artesanos de Comunicación \\ Coordinador editorial: José Manuel de Pablos - jpablos@,ull.edu.es \\ Comité Científico \\ Presidencia: José Luis Piñuel Raigada (UCM) \\ Secretaría: Milena Trenta}

- Núria Almiron (Universidad Pompeu Fabra, UPF)

- Francisco Campos Freire (Universidad de Santiago de Compostela)

- José Cisneros (Benemérita Universidad Autónoma de Puebla, BUAP)

- Bernardo Díaz Nosty (Universidad de Málaga, UMA)

- Carlos Elías (Universidad Carlos III de Madrid, UC3M)

- Paulina B. Emanuelli (Universidad Nacional de Córdoba, UNC)

- José Luis González Esteban (Universitas Miguel Hernández de Elche, UMH)

- Marisa Humanes (Universidad Rey Juan Carlos, URJC)

- Juan José Igartua (Universidad de Salamanca, USAL)

- Xosé López (Universidad de Santiago de Compostela)

- Maricela López-Ornelas (Universidad Autónoma de Baja California, UABC)

- Octavio Islas (Universidad de los Hemisferios, Ecuador)

- Javier Marzal (Universidad Jaume I, UJI)

- José Antonio Meyer (Benemérita Universidad Autónoma de Puebla, BUAP)

- Ramón Reig (Universidad de Sevilla, US)

- Miquel Rodrigo Alsina (Universidad Pompeu Fabra, UPF)

- Xosé Soengas (Universidad de Santiago de Compostela)

- José Luis Terrón (Universidad Autónoma de Barcelona, UAB)

- José Miguel Túñez (Universidad de Santiago, USC)

- Victoria Tur (Universidad de Alicante, UA)

- Miguel Vicente (Universidad de Valladolid, UVA)

- Ramón Zallo (Universidad del País Vasco, UPV-EHU)

\footnotetext{
* Queda expresamente autorizada la reproducción total o parcial de los textos publicados en este libro, en cualquier formato o soporte imaginables, salvo por explícita voluntad en contra del autor o autora o en caso de ediciones con ánimo de lucro. Las publicaciones donde se incluyan textos de esta publicación serán ediciones no comerciales y han de estar igualmente acogidas a Creative Commons. Harán constar esta licencia y el carácter no venal de la publicación.
}

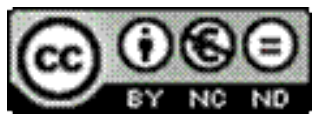

Este libro y cada uno de los capítulos que contiene (en su caso), así como las imágenes incluidas, si no se indica lo contrario, se encuentran bajo una Licencia Creative Commons Atribución-No Comercial-Sin Derivadas 3.0 Unported. Puede ver una copia de esta licencia en http://creativecommons.org/licenses/by-nc-nd/3.0/ Esto significa que Ud. es libre de reproducir y distribuir esta obra, siempre que cite la autoría, que no se use con fines comerciales o lucrativos y que no haga ninguna obra derivada. Si quiere hacer alguna de las cosas que aparecen como no permitidas, contacte con los coordinadores del libro o con el autor del capítulo correspondiente.

* La responsabilidad de cada texto es de su autor o autora. 


\author{
Editoras/es \\ Erica Conde Vázquez \\ Julia Fontenla Pedreira \\ José Rúas Araújo
}

Prólogo: José Rúas Araújo

\title{
Debates electorales televisados: del antes al después
}

Alan Schroeder / Antón R. Castromil / Raquel Rodríguez / Fermín Galindo Arranz / Juan Carlos Regueira Rey / María Gallego-Reguera / Isabel Martínez Martínez / Beatriz Legerén / Ana Belén Fernández Souto / Inmaculada Anaya / Miljana Micovic / Enrique Núñez-Mussa / José Rúas-Araújo / Andrés Mazaira Castro / Iván Puentes-Rivera / Paulo Carlos LópezLópez / Montse Vázquez-Gestal / Erica Conde-Vázquez / Casandra López Marcos / Julia Fontenla-Pedreira / Concha Pérez-Curiel y Mar García-Gordillo

Cuadernos Artesanos de Comunicación / 154
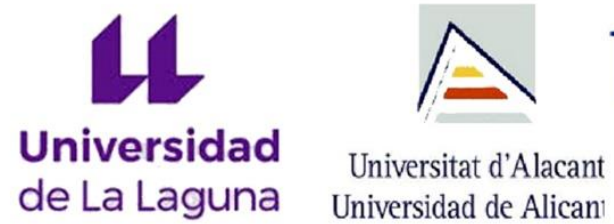

Universidad de Alican
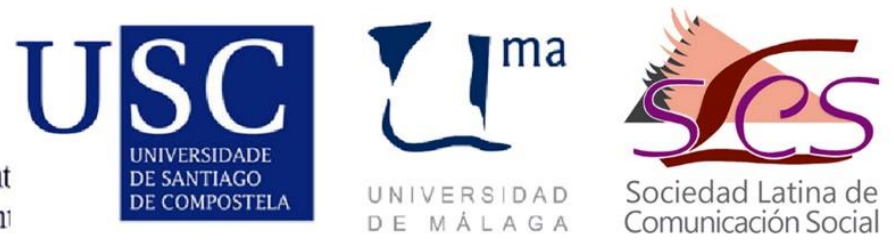
CAC $154^{\circ}$ - Debates electorales televisados: del antes al después

Editoras/es | Erica Conde-Vázquez, Julia Fontenla-Pedreira, José Rúas-Araújo y prólogo de José Rúas-Araújo.

Precio social: $11,05 €$ | Precio en librería 14,35€ |

Editores: Javier Herrero y Milena Trenta

Diseño: F. Drago

Ilustración de portada: Fragmento del cuadro "Mujer de Fuenteventura", de Vale (Bolonia).

Imprime y distribuye: F. Drago. Andocopias S. L.

c/ La Hornera, 41. La Laguna. Tenerife.

Teléfono: 922250554 | fotocopiasdrago@,telefonica.net

Edita: Sociedad Latina de Comunicación Social - edición no venal

- La Laguna (Tenerife), 2019 - Creative Commons

http://www.revistalatinacs.org/14SLCS/portada2014.html

Descargar en pdf:

http://www.cuadernosartesanos.org/\#cac154

Protocolo de envío de manuscritos con destino a CAC:

http://www.cuadernosartesanos.org/protocolo.html

ISBN - 13: 978-84-17314-14-9

DL: TF-166-2019

DOI: $10.4185 / \operatorname{cac} 154$ 


\section{Índice}

Prólogo. Debates dentro, fuera y más allá de la pantalla José Rúas-Araújo

\section{EL CONTEXTO}

1. Debates en el intermedio: los Midterm de 2018 en USA Alan Schroeder.

2. Del “cara a cara” a los debates "a cuatro" en España Antón R. Castromil y Raquel Rodríguez

\section{LA PUESTA EN ESCENA}

3. En el exoesqueleto: la preproducción de la campaña electoral Fermín Galindo Arranz y Juan Carlos Regueira Rey

4. Organización!: producción y realización de los debates electorales en España (1993-2016)

María Gallego-Reguera e Isabel Martínez Martínez

5. ¿Qué ven mis ojos?: análisis de la puesta en escena de los debates con Eye-Tracking

Beatriz Legerén y Ana Belén Fernández Souto

\section{EL CONTENIDO}

6. "Hasta aquí hemos llegado": análisis lingüístico y pragmático del debate entre Mariano Rajoy y Pedro Sánchez Inmaculada Anaya y Miljana Micovic

7. E1 rol de los periodistas como entrevistadores en los debates presidenciales

Enrique Núñez-Mussa 
8. Agenda mediática y política: ¿Amistades peligrosas? Un análisis desde el fact-checking

José Rúas-Araújo y Andrés Mazaira Castro

9. Seducir a la audiencia televisiva: la autopromoción permanente Iván Puentes-Rivera, Paulo Carlos López-López y Montse Vázquez-Gestal

10. Primarias, ¿para qué?: la imagen de los candidatos del PSOE en los medios

Erica Conde-Vázquez

\section{DE LA TELEVISIÓN A LAS SEGUNDAS PANTALLAS}

11. De Escocia a Cataluña: el debate de la independencia en las redes sociales

Casandra López Marcos

12. Las televisiones autonómicas en las redes sociales Julia Fontenla-Pedreira

13. Formato televisivo y proyección en Twitter de las elecciones en Andalucía

Concha Pérez-Curiel y Mar García-Gordillo

Los autores y las autoras

Este libro ha sido sometido a un proceso de revisión doble, al estilo de las evaluaciones realizadas para un artículo publicado en una revista científica

Este libro ha sido sometido al filtro en un programa antiplagio, en concreto al programa anti copia Turnitin, existente en la Universidad de Santiago de Compostela 


\title{
Debates electorales televisados: del antes al después
}

Editoras/es: Erica Conde-Vázquez, Julia Fontenla-Pedreira y José Rúas-Araújo

\begin{abstract}
Este libro analiza los nuevos formatos y estrategias de comunicación política vinculados a la televisión, en general, y los distintos modelos de debates electorales televisados, en particular, describiendo, en perspectiva comparada, la organización, difusión e impacto de estos encuentros, además de realizar un diagnóstico de todo el proceso: desde la negociación de los debates y sus condiciones con los responsables de las cadenas implicadas (el antes), como la realización, puesta en escena, formato y contenidos (durante), y su repercusión en términos de percepción, audiencia y posibles efectos (después), incluyendo las redes sociales.
\end{abstract}

Keywords: Debates electorales, televisión, producción, realización, difusión, audiencias, prensa, lenguaje, discurso, eye-tracking, factchecking, redes sociales.

Forma de citar este libro:

Conde-Vázquez, E., Fontenla-Pedreira, J. y Rúas-Araújo, J. (Eds.) (2019). Debates electorales televisados: del antes al después. Cuadernos Artesanos de Comunicación, cac 154. La Laguna (Tenerife): Latina. 



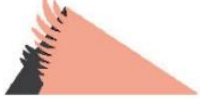 \\ Prólogo \\ Debates dentro, fuera y más allá de la pantalla}

$\mathrm{E}$ STA OBRA analiza los nuevos formatos y estrategias de comunicación política vinculados a la televisión, en general, y los distintos modelos de debates electorales televisados, en particular, describiendo, en perspectiva comparada, la organización, difusión e impacto de estos encuentros, además de realizar un diagnóstico de todo el proceso: desde la negociación de los debates y sus condiciones con los responsables de las cadenas implicadas (el antes), como la realización, puesta en escena, formato y contenidos (durante), y su repercusión en términos de percepción, audiencia y posibles efectos (después).

Debates electorales que trascienden el espacio y límites temporales del tradicional formato televisivo para implicar a nuevos medios y audiencias, que reclaman una mayor implicación en el diseño de la agenda y los temas de discusión política, mediática y ciudadana.

De hecho, el actual proceso de convergencia e hibridación mediática, a través de la utilización de segundas pantallas, obliga también a afrontar nuevos retos y perspectivas que den respuesta a las exigencias de incorporación de las redes sociales al debate político, al cumplimiento de la función social de las televisiones como servicio de interés general y público y a su responsabilidad en la promoción de la deliberación y participación electoral y la mejora de la calidad de los procesos democráticos.

El libro se distribuye en cuatro partes: 1. El contexto, 2. La puesta en escena, 3. El contenido y 4. De la televisión a las segundas pantallas. En la primera, Alan Schroeder, profesor de la Northeastern University de Boston (USA), hace una descripción de los debates electorales en 
Estados Unidos y, en concreto, los celebrados con motivo de las recientes elecciones de mitad de legislatura (Midterm), concluyendo que factores como la polarización política, el escepticismo del público hacia la gobernanza democrática y el auge de las redes sociales, han contribuido a crear un entorno bastante más agresivo que en décadas pasadas. En esta primera parte se incluye también un capítulo de los profesores Antón R. Castromil, de la Universidad Complutense de Madrid, y Raquel Rodríguez, de la Universidad Rey Juan Carlos, que describen y comparan el paso de los debates "cara a cara" a los debates "a cuatro", surgidos tras la ruptura del bipartidismo en España.

En la segunda parte del libro, sobre la puesta en escena, Fermín Galindo de la Universidad de Santiago de Compostela (USC) y Juan Carlos Regueira, de la Televisión de Galicia (TVG), se detienen en la fase de preproducción de la campaña electoral, que denominan el exoesqueleto informativo, con la intención de mostrar la paradoja de que las mismas normas que limitan la agilidad informativa, ayudan a que se produzca el necesario consenso y avance en la realización de los debates. Asimismo, María Gallego, del Centro de Educación Superior Next, e Isabel Martínez, de la Universidade de Vigo, hacen un repaso por el formato y la realización de los debates televisados celebrados en España, desde 1993 hasta el año 2016, en cuanto a las exigencias técnicas, como la disposición de los candidatos, el número de cámaras y tipo de planos, iluminación y música. Relacionado también con la puesta en escena de los debates, Ana Belén Fernández Souto y Beatriz Legerén, de la Universidade de Vigo, realizan un análisis utilizando técnicas de Eye-Tracking, con la intención de observar aquellos aspectos de atraen la mirada y atención de los espectadores.

Con respecto a la tercera parte del libro, sobre el contenido, Inmaculada Anaya, de la Universidade de Vigo, y Miljana Micovic, del Centro de Educación Superior Next, realizan un análisis lingǘstico del "cara a cara" celebrado en 2015 entre Mariano Rajoy (PP) y Pedro Sánchez (PSOE), desde una perspectiva funcional y pragmática, a partir de sus respectivas estrategias de ataque y defensa. Asimismo, Enrique Núñez, de la Pontificia Universidad Católica de Chile, examina los distintos roles de los periodistas como entrevistadores en los debates presidenciales televisados, concluyendo que éstos apenas han 
avanzado, desde su inicio hasta la actualidad, mientras que José Rúas y Andrés Mazaira, de la Universidade de Vigo, se centran en comparar la agenda mediática de la precampaña con la agenda y temas de los candidatos que intervienen en los debates televisados durante la campaña electoral, demostrando el alineamiento y ensamblaje existente entre ambas. Por su parte, Iván Puentes, Paulo Carlos López-López y Monserrat Vázquez Gestal, de la Universidade de Vigo, analizan los anuncios de acciones de autopromoción realizados por las televisiones protagonistas de los debates electorales, mientras que Erica Conde, de la Universidade de Vigo examina el impacto, en términos de imagen, de los debates entre los distintos candidatos a las elecciones primarias del PSOE, en los medios de comunicación.

En la cuarta y última parte del libro, sobre el paso de la televisión a las segundas pantallas, Casandra López, del Centro de Educación Superior Next, observa el uso de las redes sociales por parte de los medios de comunicación, a propósito de los debates sobre la independencia en los casos de Escocia y Cataluña. Asimismo, Julia Fontenla, de la Universidade de Vigo, analiza la presencia en las redes sociales YouTube e Instagram en las televisiones autonómicas, con motivo de los distintos debates electorales celebrados.

Finalmente, Concha Pérez Curiel y Mar García Gordillo, de la Universidad de Sevilla, investigan en qué medida los debates emitidos durante la campaña de las elecciones andaluzas supusieron una fuente de información relevante para las audiencias, tanto tradicionales como a través de Twitter.

El libro forma parte de los trabajos desarrollados en el marco del proyecto de investigación "DEBATv, Debates Electorales Televisados en España: Modelos, Proceso, Diagnostico y Propuesta (CSO201783159-R)", proyecto de I+D+I (Retos) financiado por el

Ministerio de Economía, Industria y Competitividad (MINECO), la Agencia Estatal de Investigación (AEI) y el Fondo Europeo de Desarrollo Regional (FEDER) de la Unión Europea (UE).

El proyecto cuenta con el apoyo de la Federación de Organismos de Radio y Televisión Autonómicos (FORTA), la Academia de las 
Ciencias y las Artes de TV y la Unión de Televisiones Comerciales en Abierto (UTECA).

José Rúas Araújo

Universidade de Vigo

PARA CITAR: Rúas-Araújo, J. (2019). "Debates dentro, fuera y más allá de la pantalla" En Conde-Vázquez, E., Fontenla-Pedreira, J. y RúasAraujo, J. (Eds.), Debates electorales televisados: del antes al después (pp. 9-12) Cuadernos Artesanos de Comunicación, cac 154. La Laguna (Tenerife): Latina. 


\title{
Debates en el intermedio: Los Midterm de 2018 en USA
}

\author{
Alan Schroeder \\ Northeastern University de Boston
}

\begin{abstract}
PARA CITAR: Schroeder, A. (2019). "Debates en el intermedio: los Midterm de 2018 en USA". En Conde-Vázquez, E., Fontenla-Pedreira, J. y Rúas-Araújo, J. (Eds.), Debates electorales televisados: del antes al después (pp. 13-25). Cuadernos Artesanos de Comunicación, cac 154. La Laguna (Tenerife): Latina. DOI: 10.4185/cac154
\end{abstract}

\section{Resumen}

Las elecciones primarias y generales celebradas en 2018 en los Estados Unidos de América, que supusieron la celebración de más de un centenar de debates electorales televisados, muestran que el entorno ha cambiado, con enfrentamientos más conflictivos y un creciente desprecio por la seriedad política. Un entorno cambiante que también ha afectado a la reciente celebración, en noviembre de 2018, de las elecciones de mitad de legislatura (midterm), que supusieron una participación histórica, de casi el 50\% de la población del país, con más de 116 millones de votos, frente al 36,7\% registrado en los comicios anteriores, de 2014.

Palabras clave: USA, debates presidenciales, candidatos, midterm, medios de comunicación. 


\section{Introducción}

$\mathrm{D}$ ESDE 1960, cuando John F. Kennedy se reunió con Richard Nixon en el primer debate presidencial televisado del mundo, los debates entre candidatos se han convertido en un elemento inevitable de las campañas políticas estadounidenses. Hoy en día, en el país que inventó debates televisados, casi ningún aspirante a cargo público puede evitar encontrarse con su oponente en un cara-a-cara. No importa el nivel del puesto, desde la presidencia de la nación hasta la alcaldía de un municipio local.

Las elecciones de 2018 en Estados Unidos incluyeron cientos de debates entre candidatos, que se llevaron a cabo en todos los 50 estados, tanto durante el período de elecciones primarias como antes de las elecciones generales de noviembre. $\mathrm{Y}$ aunque muchos aspectos de debates no han cambiado desde la era Kennedy-Nixon, los candidatos que debaten hoy operan en un mundo político y mediático que ha cambiado dramáticamente. La polarización política, el escepticismo del público hacia la gobernanza democrática, y el auge de las redes sociales han contribuido a crear un entorno bastante más agresivo que en décadas pasadas.

"Los debates son mucho más conflictivos ahora", según Ron Klain, un entrenador profesional bien conocido y muy respetado en Washington, DC, que ha ayudado a preparar a todos los candidatos demócratas presidenciales para sus debates desde Bill Clinton en 1992. En una entrevista con el portal de noticias Axios, Klain explicó: "El énfasis ha pasado de persuadir a los votantes indecisos a motivar a sus propios partidarios, y al mostrar a sus partidarios que luchará por lo que cree."1

Hasta cierto punto, esta nueva actitud pugilista hacia los debates puede vincularse con las payasadas grandilocuentes de Donald Trump, cuyo desprecio por la seriedad política ha infectado en absoluto el proceso electoral estadounidense. Pero incluso antes de la llegada de Trump a la escena política, el tono de los debates había cambiado, como vimos

\footnotetext{
${ }^{1}$ Mike Allen, "Fight club: New debate rules for the Trump era," Axios.com, 20 August 2019, https://www.axios.com/2018-midterm-elections-debate-rulesage-of-trump-e29a9b19-3537-40b8-b5c6-5f02638f2ba3.html
} 
en los encuentros de 2012 entre Barack Obama y Mitt Romney. Estos debates fueron mucho más conflictivos que los debates presidenciales estadounidenses anteriores, lo que indica una ruptura de los encuentros, relativamente educados, del pasado.

Tanto Ron Klain, antes citado, como su colega John Neffinger creen que las personas que juzgan los debates - es decir, los periodistas y los votantes - "han llegado a ver los debates como un ejercicio competitivo, no solo como una oportunidad de entregar información, y están buscando un ganador para coronar y un perdedor para avergonzar". Ya no se aconseja a los debatientes que traten a sus oponentes con guantes de seda, por temor a que los ataques personales sean contraproducentes para la persona que los lanza. En opinión de Klain y Neffinger, navegar pasivamente sobre la lucha e ignorar al oponente ya no es estrategia viable en debate. ${ }^{2}$

Esto que nos lleva a 2018, y las elecciones midterm estadounidenses. Sin una carrera presidencial compitiendo por la atención, los votantes y los medios de comunicación dieron un escrutinio inusualmente intensivo a los concursos para gobernador, Senado, Cámara de Representantes y otros puestos de representación estatal y local.

La participación electoral en 2018 alcanzó el nivel más alto de todas las elecciones midterm en los Estados Unidos en más de un siglo, con el 49,3\% de la población emitiendo más de 116 millones de votos. Por comparación, las previas elecciones midterm de 2014 solo atrajeron al $36.7 \%$ de los votantes ${ }^{3}$. Esta fuerte respuesta electoral se reflejó en la atención prestada a los debates de 2018, especialmente en las carreras de alto perfil para gobernadores y en los escaños en el Congreso nacional.

2 Ibid.

${ }^{3}$ Emily Stewart, "2018's record-setting voter turnout, in one chart," Vox.com, 19 November 2018, https://www.vox.com/policy-andpolitics/2018/11/19/18103110/2018-midterm-elections-turnout 


\section{Antecedentes de los midterm de 2018}

Las elecciones de 2018 incluyeron elecciones para gobernador en 36 de los 50 estados. Treinta y cinco escaños del Senado de los Estados Unidos fueron elegidos (cada estado tiene dos senadores, y los senadores sirven por períodos de seis años), junto con los 435 escaños de la Cámara de Representantes, que se disputan cada dos años. En casi todas estas carreras, los candidatos participaron en algún tipo de debate cara-a-cara. Muchos de estos eventos recibieron cobertura a nivel nacional, aunque las elecciones en cuestión se limitaron a estados y distritos individuales.

En gran medida, el alto nivel de interés por los votantes en los midterms de 2018 puede explicarse por la ausencia de una carrera presidencial. Esto se desvió la atención a concursos de niveles inferiores, particularmente en estados populosos y políticamente divididos, como Florida, Tejas, Georgia, Pensilvania y Ohio. Debates entre los candidatos en estas carreras recibieron visibilidad nacional: la red de noticias por cable $\mathrm{CNN}$, por ejemplo, emitió un debate entre candidatos por gobernador de Florida que fue televisado a nivel nacional. Más extensamente, la red de asuntos públicos C-SPAN entregó a las audiencias de todo el país la oportunidad de ver docenas de debates que se llevaron a cabo en estados y localidades por todo el país.

Un segundo motivo, más consecuente, para el gran interés en los midterms de 2018 no se puede ignorar. Aunque Donald Trump no estaba en la disputa electoral, la elección de 2018 fue interpretada ampliamente como un referéndum sobre los primeros dos años en el cargo de Trump, un referéndum en el que los votantes expresaron rotundamente su descontento con el ocupante de la Casa Blanca. Según un análisis posterior a las elecciones realizado por el Pew Research Center, el partidismo y desagrado hacia el partido opuesto y sus candidatos fueron factores más importantes para los votantes. Los investigadores encontraron que "una parte sustancial de los votantes demócratas que citaron a la oposición como un factor, 
aproximadamente uno de cada cinco votantes demócratas (21\%) dijo que su voto fue principalmente en oposición a Donald Trump."4

En este contexto de polarización política, los candidatos en 2018 entraron en la arena del debate con el espectro de Trump flotando silenciosamente en lo alto. Como resultado, los demócratas trataron de vincular lo más posible a sus opositores republicanos con el presidente impopular, mientras simultáneamente se abordaban temas de interés para los votantes que no involucraban a Trump. Los candidatos republicanos, por otro lado, se encontraron en la precaria posición de tener que parecer independientes de Trump, con la intención de apelar al electorado general, pero sin ofender a los millones de seguidores acérrimos del presidente en el partido republicano.

A pesar de que Trump era tema de discusión ineludible en los debates midterm de 2018, los candidatos de ambas partes mantuvieron la mayor parte de su atención en temas de interés relevantes para el público general: el sistema de cuidado de la salud, la economía, la política ambiental, y la inmigración, por citar algunos. Cuando el tema de Trump surgió en los debates, el resultado para los candidatos republicanos podría ser incómodo. En un debate de gran confrontación entre los aspirantes de ser gobernador de Florida, el demócrata Andrew Gillum se refirió al opositor republicano Ron DeSantis como un "títere" de Trump. "Donald Trump es débil," dijo Gillum, "y actúa como lo hacen todas las personas débiles: se convierten en matones. Y el señor DeSantis es su acólito." 5

A lo largo de la campaña, DeSantis se alineó sin disculpas con Trump. En un anuncio televisivo de su candidatura, DeSantis leyó en voz alta a sus hijos pequeños una copia del libro de Trump "El arte del trato" y

\footnotetext{
${ }^{4}$ Amina Dunn, John LaLoggia and Carroll Doherty, "In midterm voting decisions, policies took a back seat to partisanship," Pew Research Center, Factank, 29 November 2018, http://www.pewresearch.org/facttank/2018/11/29/in-midterm-voting-decisions-policies-took-a-back-seat-topartisanship/

${ }^{5}$ Patricia Mazzei, "Florida Governor Candidates Andrew Gillum and Ron DeSantis Face Off in Contentious Debate," New York Times, 21 October 2018, https://www.nytimes.com/2018/10/21/us/politics/gillum-desantis-floridadebate.html
} 
construyó un muro de bloques de juguete con ellos en honor a la postura anti inmigratoria de Trump. Durante el debate, cuando un panelista le preguntó a DeSantis si Trump era un buen ejemplo para los niños de Florida, el candidato respondió de manera absurda, elogiando al presidente por haber trasladado la embajada estadounidense en Israel desde Tel-Aviv a Jerusalén. Solo más tarde, cuando se le pidió una aclaración en una entrevista pos-debate, DeSantis respondió a la pregunta, diciendo que el presidente merece admiración por cumplir sus promesas. DeSantis pasó a ganar la elección por un estrecho margen.

\section{Participación en los 2018 midterm}

Después de seis décadas de debates televisados como un ritual de campaña estadounidense, es notable que en 2018 los candidatos todavía parezcan reacios a debatir con sus oponentes en el campo de batalla del cara-a-cara. Pero como en las elecciones pasadas, muchos de los candidatos midterm intentaron minimizar o evitar por completo su participación en los debates. En todas partes de la nación, los debates se planificaron y luego se cancelaron cuando los candidatos encontraron razones para no participar.

En algunos casos las cancelaciones fueron legítimas. Un debate entre candidatos para el Senado en Florida, por ejemplo, tuvo que posponerse debido a la devastación causada por el huracán Michael, unas semanas antes de la votación. Pero otras cancelaciones ocurrieron porque los candidatos deliberadamente eludieron la participación. Cuando el senador republicano de Tejas Ted Cruz rechazó una invitación de CNN para un "town hall" televisado a nivel nacional con su oponente, el congresista demócrata Beto O'Rourke, el canal CNN produjo el evento con O'Rourke como el único participante, dando al retador una hora de exposición a la televisión nacional que mejoró enormemente su perfil, tanto en Tejas como en otros lugares. (Cabe mencionar que más tarde en la campaña los candidatos tejanos tuvieron dos debates muy vistos).

El ejemplo de Beto O'Rourke es útil al considerar el papel que juegan los debates en las campañas electorales y en las carreras de los 
profesionales políticos. Aunque los candidatos a menudo temen la posibilidad de debatir con sus oponentes, en realidad los debates televisados ofrecen una oportunidad casi en paralelo para que los aspirantes políticos se dirijan a un gran número de votantes a la vez. A diferencia de los anuncios publicitarios y los mítines, los debates no imponen costes financieros a los candidatos: la plataforma se proporciona de forma gratuita por los patrocinadores y los medios de comunicación que transmiten el evento. Puede ser intimidante ponerse al lado de su rival para un diálogo en vivo y sin guión, pero en la mayoría de los casos los beneficios potenciales parecen superar los costos. Es un axioma de la política estadounidense que cada gobernador de cada estado y cada miembro del Senado y de la Cámara de Representantes se miran en el espejo todos los días y ve a un posible presidente. Los debates dan a los candidatos la oportunidad de mostrar al electorado que estas aspiraciones pueden tener algún fundamento de hecho.

Beto O'Rourke perdió su carrera en Tejas, pero salió de la campaña como una estrella en ascenso entre los votantes demócratas y periodistas políticos. Como un personaje telegénico y simpático, O'Rourke demostró un talento formidable en sus dos debates con Ted Cruz. La gran mayoría de observadores esperan que O'Rourke, de 46 años, vuelva a postularse para el cargo en el futuro, quizás incluso como candidato presidencial en 2020. La experiencia de O'Rourke como debatiente en 2018 le otorga una credencial que le será útil como su carrera política avanza.

Naturalmente, no todos los candidatos aportan este mismo grado de fluidez mediática a sus campañas. La participación en debates en vivo es particularmente peligrosa para aquellos que no se sientan cómodos ante la cámara o que carecen de conocimientos básicos sobre temas que los votantes consideran importantes. Tal fue el caso de Cindy Hyde-Smith, candidata republicana al Senado del estado de Mississippi, cuyos errores verbales durante la campaña la hicieron cada vez más muda antes de la votación. Preparando para su único debate, HydeSmith y sus asesores hicieron todo lo posible para minimizar el peligro. 
No se permitió una audiencia en vivo dentro del sitio del debate, incluidos los miembros de la prensa. Hyde-Smith insistió en llevar con ella notas a su atril. Esto es muy inusual en los debates estadounidenses, que valoran la espontaneidad sobre los comentarios preparados. Según el plan original, se suponía que Hyde-Smith y su oponente se hacían una pregunta directamente como parte del debate, pero estas preguntas fueron leídas por los periodistas en el panel. La campaña de HydeSmith tuvo éxito con estas demandas debido a su posición como favorita en un estado que favorece mucho a su partido. Además, el debate fue patrocinado por una organización cívica llamada Mississippi Farm Bureau, cuyos miembros principales de la junta habían hecho donaciones financieras a Hyde-Smith. "Han manipulado este debate para que ella gane," se quejó un representante de la campaña opuesta. ${ }^{6}$

Al final resultó que Hyde-Smith dio una actuación horrible. Dependiendo en gran medida de sus notas escritas, la candidata se repetía con frecuencia y en ocasiones no tenía sentido. (Para ser justos, su oponente, un ex-congresista afroamericano llamado Mike Espy, también dio una actuación inferior). La victoria de Hyde-Smith en la elección atestigua más el racismo persistente de Mississippi que la destreza política de la candidata. Y demuestra que incluso un fracaso en debate no obstruye automáticamente la victoria electoral; HydeSmith ganó el escaño en el Senado por ocho puntos porcentuales.

Durante las primarias del partido demócrata en 2018, el gobernador actual Andrew Cuomo se enfrentó a una retadora inesperada, la recién llegada política Cynthia Nixon, una actriz mejor conocida por ser coprotagonista en la serie de televisión "Sex and the City."

\footnotetext{
${ }^{6}$ Ashton Pittman and Ko Bragg, "Hyde-Smith demanded no audience, no pressfortonight'sdebate,'JacksonFreePress,20November2018,http://www.jacks onfreepress.com/news/2018/nov/20/hyde-smith-demanded-no-audience-nopress/
} 


\section{Negociaciones y formatos en los 2018 midterm: cuestión de temperatura}

Las negociaciones previas al debate se han convertido en una especie de deporte de sangre en las campañas políticas estadounidenses, y 2018 no fue la excepción.

Un debate entre precandidatos para ser el gobernador del estado de Nueva York provocó una pequeña controversia pre-debate sobre un tema que ha sido desconcertante para los asesores políticos desde los debates Kennedy-Nixon de 1960: dónde establecer la temperatura en la sala de debate.

Antes del único cara a cara de la campaña, los asesores de Nixon solicitaron que la temperatura del estudio se fijara en 76 grados Fahrenheit (24.5 grados centígrados) para evitar lo que una portavoz describió como ajustes de temperatura "notoriamente sexistas", comúnmente encontrado en lugares de trabajo. La campaña de Cuomo respondió publicando en Twitter una foto de un perro acalorado "recuperándose" en un lecho de cubitos de hielo después de "asistir a la preparación del debate en la temperatura preferida del Equipo Nixon.". La conversación pronto explotó en las redes sociales, y se convirtió en un mini-debate sobre el "patriarcado del termostato", una referencia a los espacios de oficinas donde los termostatos tradicionalmente se reducen en los meses de verano para acomodar a los hombres que usan trajes. ${ }^{7} \mathrm{Al}$ final, cuando sucedió el debate, se rechazó la solicitud de Nixon para tener un estudio cálido.

Las negociaciones antes de un debate gubernativo en Maryland en 2018 dieron un giro desagradable cuando se reveló que la campaña del candidato demócrata Ben Jealous había vetado en secreto a una de los periodistas que se suponía debía servir como interrogadora en el panel de debate. Una vez que esta noticia salió a la luz, la campaña rescindió inmediatamente su veto y restauró la invitación a la periodista.

\footnotetext{
${ }^{7}$ Gregory Krieg, "Nixon and Cuomo are talking climate (of the room where they'll debate)," CNN.com, 29 August 2018, https://www.cnn.com/2018/08/28/politics/cynthia-nixon-andrew-cuomodebate-heat/index.html
} 
Normalmente, tales detalles secretos de la negociación nunca se harían públicos, pero en este caso, la campaña opuesta vio la oportunidad de obtener una ventaja al exponer las maquinaciones detrás de cortinas, con la esperanza de hacer que Jealous parezca mezquino y vengativo. ${ }^{8}$

Esta no fue la primera violación de la confidencialidad relacionada con el debate por parte del oponente de Jealous, el gobernador republicano de Maryland, Larry Hogan. Un par de semanas antes del incidente con el panelista, los asesores de Hogan tomaron la medida extraordinaria de entregar a los reporteros correos electrónicos privados entre las dos campañas en las que se estaban negociando los detalles del debate. Hogan esperaba avergonzar a su oponente al revelar que en privado Jealous estaba pidiendo un solo debate, mientras que en público pedía cinco. No está claro por qué la campaña de Hogan creía que esta inconsistencia resonaría como una cuestión de importancia para los votantes; incluso los periodistas políticos le dieron una cobertura mínima. ${ }^{9}$ Pero el incidente nos recuerda el vitriolo que frecuentemente acompaña a las negociaciones de debate, en las cuales los desacuerdos más triviales pueden convertirse en una guerra total.

Uno de los puntos más negociados en cualquier debate, por supuesto, es el formato. Los debates midterm de 2018 abarcaron una amplia gama de formatos, desde "town halls" y conversaciones sentados, hasta los arreglos más tradicionales en los que los candidatos se ponen a pies debajo de atriles. En una época de alta participación ciudadana, muchos debates ahora incorporan preguntas sometidas por los votantes mismos. Aunque los debates no se han convertido en ejercicios totalmente interactivos, en 2018 vimos que la voz del pueblo forma parte, más que nunca, de los debates electorales.

\footnotetext{
${ }^{8}$ Andrew Schotz, "Jealous campaign rescinds veto of Herald-Mail media reporter from debate," Hagerstown Herald-Mail, 18 September 2018, https://www.heraldmailmedia.com/news/election 2018/jealous-campaignrescinds-veto-of-herald-mail-media-reporter-from/article 4ab140f8-bbb6-11e8a954-5f9832007c7d.html

${ }^{9}$ David Collins, "Debate on debate: Hogan campaign releases private emails with Jealous campaign," wbaltv.com, 7 September 2018, https://www.wbaltv.com/article/debate-on-debate-hogan-campaign-releasesprivate-emails-with-jealous-campaign/23027821
} 
Desde hace muchas décadas, el interrogatorio por periodistas ha sido un elemento fundamental de los debates electorales, empezando con Kennedy y Nixon. Esta tendencia ha continuado, al menos en parte, porque la mayoría de los debates estadounidenses están patrocinados por organizaciones de noticias que desean mostrar su propio personal. Las preguntas periodísticas pueden ser aburridas y predecibles, o pueden generar percepciones nuevas e inesperadas sobre los candidatos. Al final del segundo y último debate en Tejas entre Ted Cruz y Beto O'Rourke, uno de los periodistas que actuó como moderador desafió a los candidatos a "decirnos algo que haya hecho en el último año que no tenga nada que ver con la política y le daría a los tejanos una idea de quién eres como persona."

Las respuestas fueron en efecto reveladoras de cada candidato. Después de una pausa incómoda, el senador Cruz aprovechó la oportunidad para repetir un mensaje personal pero suntuoso que había transmitido en un debate anterior sobre las dificultades de criar a sus hijos pequeños mientras prestaba servicio en el Senado. O'Rourke, en comparación, habló en un tono jovial de irse al sótano de su casa para realizar sesiones musicales ruidosas con sus tres hijos. "Los niños y yo rock out," dijo O'Rourke, pintando una imagen vívida de una familia que se divierte juntos y que contrasta con los clichés y las piedades de Cruz. ${ }^{10}$

Quizás la decisión programática más desaconsejada por los organizadores de los debates midterm de 2018 fue seleccionar a un presentador del mundo de entretenimiento como moderador del caraa-cara gubernativo de Pensilvania. Desde 1984 Alex Trebek ha sido el presentador de "Jeopardy," un popular programa televisado diario en el que los participantes contestan preguntas triviales de muchas categorías. En entrevistas de prensa a lo largo de varios años, Trebek había expresado su deseo de moderar un debate entre candidatos

${ }^{10}$ Todd J. Gillman and Robert T. Garrett, "Gloves off in $2^{\text {nd }}$ Cruz-O'Rourke debate," Dallasnews.com, 16 October 2018, https://www.dallasnews.com/news/2018-elections/2018/10/16/watch-texassenate-candidates-ted-cruz-beto-orourke-debate-before-2018-midterm-elections 
políticos, pero cuando llegó su oportunidad, el resultado fue nada menos que desastroso.

Trebek fue criticado por partidarios de todas las tendencias políticas por tomar partido, desviarse de temas importantes y, sobre todo, hablar más tiempo que los candidatos, que eran las estrellas verdaderas del espectáculo. La reacción fue especialmente negativa en Twitter, donde los observadores acumularon 22 minutos de tiempo de conversación para Trebek, en comparación con 17 y 13 minutos para los dos candidatos, respectivamente. En un momento dado durante el debate, Trebek cayó en un soliloquio irrelevante, de un minuto de duración, sobre las tribulaciones de la Iglesia Católica. Cuando terminó el debate, el público en la sala lo abucheaba. ${ }^{11}$

Dos días después del debate, Trebek emitió una disculpa por su desempeño, diciendo que "no reconocí la seriedad del evento para los votantes. Pensé que como moderador, debía proporcionar un cierto enfoque alegre al mismo tiempo que aún podía desafiar a los candidatos en sus historias o posiciones. No me di cuenta de que tenía que hacer una pregunta simple y luego dejar que los caballeros se enfrentaran."12 Es difícil comprender por qué los patrocinadores de este debate contrataron a Trebek para un trabajo que él entendió tan mal, o por qué las dos campañas aprobaron una selección tan ridícula.

\section{Legado de los midterm de 2018}

Aunque 2018 no fue un año histórico en la historia de los debates electorales estadounidenses, el ciclo sí produjo un alto grado de interés por parte de los votantes y una cantidad de "minutos de oro" en You'Tube por parte de los candidatos.

${ }^{11}$ Justin Heinz, "Alex Trebek Lambasted For 'Grandstanding' At PA Gov. Debate," Patch.com, 2 October

2018,https://patch.com/pennsylvania/norristown/pa-governor-debate-gopblasts-alex-trebeks-performance

${ }^{12}$ Andrew Seidman, "Alex Trebek apologizes for his performance as moderator of Pa. Gov. debate," Philly.com, 4 October 2018, http://www.philly.com/philly/news/politics/elections/alex-trebek-apologizesfor-his-performance-as-moderator-of-pa-gov-debate-20181003.html 
Ya que la polarización se ha convertido en la política normal, los debates en los Estados Unidos ahora funcionan no para ganarse a los votantes indecisos, sino para generar entusiasmo entre los partidarios. Para los debatientes esta realidad significa que se requiere una cierta demostración de agresividad en los debates; el reto es lograr un equilibrio preciso entre agresión y positividad. Incluso un candidato como Beto O'Rourke de Tejas, que dirigió una campaña basada en el optimismo y la esperanza, tuvo que encontrar una manera de maniobrar en una atmósfera que premia el pugilismo más que la cortesía.

Con el auge de las redes sociales, los comentarios del debate pasaron de ser el territorio de los periodistas profesionales a un tema de interés para todo el electorado. Con cada elección, un mayor número de personas ve los debates no en televisión, sino a través de sitios web y aplicaciones que fomentan la interactividad. La participación en Twitter aumenta considerablemente durante los debates en vivo, y los debatientes no son juzgados por la totalidad de su desempeño, sino por su actuación de momento a momento. La presión sobre los candidatos para mantenerse al máximo durante la duración del debate jamás ha sido más intensa. El imperativo de no cometer un error se magnifica más que nunca.

Sin embargo, en gran medida, debates electorales siguen siendo lo que eran en 1960, cuando John F. Kennedy y Richard Nixon se reunieron en un estudio de televisión en Chicago. Entonces, igual que ahora, los debates son raras excepciones a la coreografía habitual de las campañas políticas. En el peor de los casos, los debates son aburridos y sobrevalorados, pero en el mejor de los casos ofrecen a los votantes una visión rara del aspecto humano de hombres y mujeres que buscan cargos políticos. Más que cualquier otra forma de comunicación política, los debates ponen a los candidatos en una situación que no pueden controlar por completo, lo cual, para los votantes, es buena noticia. 


\section{Reconocimiento de la investigación}

Este capítulo forma parte de los trabajos desarrollados en el marco del proyecto de I+D+I (Retos) "DEBATv, Debates Electorales Televisados en España: Modelos, Proceso, Diagnostico y Propuesta" (Ref. CSO2017-83159-R), financiado por el Ministerio de Economía, Industria y Competitividad (MINECO), la Agencia Estatal de Investigación (AEI) y el Fondo Europeo de Desarrollo Regional (FEDER) de la Unión Europea (UE). 


\title{
Del "cara a cara" a los debates "a cuatro" en España
}

\author{
Antón R. Castromil \\ Universidad Complutense de Madrid \\ Raquel Rodríguez \\ Universidad Rey Juan Carlos, Madrid
}

\begin{abstract}
PARA CITAR: Castromil, A. y Rodríguez, R. (2019). "Del "cara a cara" a los debates "a cuatro" en España". En Conde-Vázquez, E., FontenlaPedreira, J. y Rúas-Araújo, J. (Eds.), Debates electorales televisados: del antes al después (pp. 27-47). Cuadernos Artesanos de Comunicación, cac 154. La Laguna (Tenerife): Latina. DOI: $10.4185 /$ cac154
\end{abstract}

\section{Resumen}

Los debates electorales constituyen uno de los principales repertorios de comunicación política en toda campaña electoral que se precie. En España, sin embargo, han tenido una historia de celebraciones desigual. En muchas ocasiones, el sistema de bipartidismo imperfecto imperante obró en contra de la celebración de debates. La situación podría estar cambiando a partir de la fractura del sistema de partidos de 2015. Los debates experimentan desde entonces cambios en un doble sentido. En primer lugar, evolucionan desde un formato "cara a cara" hacia otro tipo de debates "a cuatro". Esta ampliación de actores implicados no deja de entrañar importantes cambios estratégicos y organizativos. En segundo lugar, los duelos dialécticos "a cuatro" hacen más fácil su celebración, ya que, si alguno de los partidos se niega a debatir, es probable que el resto de formaciones sí siga adelante con el debate. 
Palabras clave: Debate electoral, nuevos formatos debate, comunicación política.

\section{Introducción}

L

OS debates electorales se han convertido en uno de los principales acontecimientos que tienen lugar en las campañas electorales. Constituyen duelos dialécticos y estratégicos que entran de lleno tanto en las estrategias de comunicación política de corte mediatizada -con intervención de los medios- como no mediatizada, donde el mensaje político se transmite tal cual.

El texto que el lector tiene entre manos analiza los debates electorales desde distintos puntos de vista. En primer lugar, se diseccionan los debates desde un plano analítico-instrumental en el que este acto de campaña es aceptado o rechazado en función de las expectativas electorales de los actores.

En segundo lugar, se establece que la evolución de los debates electorales desde el tradicional formato del "cara a cara" entre los representantes de los dos partidos más votados (PP y PSOE) hacia otro tipo de debates "a cuatro" se debe a factores sistémicos. Es decir, la quiebra del sistema de partidos sucedida en 2015 está detrás del cambio. Pero esta evolución desde modelos "a dos" hasta fórmulas "a cuatro" no deja de contender dificultades. Algunas heredadas de los debates de la era del bipartidismo (1993, 2008 y 2011) y otras de nuevo cuño (2015 y 2016).

A ello se une también la irrupción de Vox en las elecciones andaluzas de diciembre de 2018, que hace presagiar que la formación ultraderechista entrará también en el parlamento nacional en las próximas elecciones generales, todavía no celebradas en el momento de escribir estas líneas. El análisis que proponemos aquí se detiene en 2016 por lo que mencionaremos los debates "a cuatro" aunque en el futuro más inmediato puedan sufrir modificaciones. Trataremos a continuación los desafíos que nos parecen más relevantes: 
1) Periodísticamente los debates "a cuatro" introducen distorsiones que los "cara a cara" no contenían.

2) Desde el punto de vista de su organización, estos debates ampliados a más actores se vuelven más complejos y, quizá también, farragosos. Sobre todo, cuando se mantienen fórmulas organizativas más pensadas para dos que para cuatro debatientes.

3) Los temas de debate que se tratan en los debates, ya sea bajo la fórmula "a dos" o "a cuatro" se encuentran pactados de antemano. Esta circunstancia, contraria a la dinámica general de una campaña electoral abierta, podría estar detrás de la sensación de que los debates se parecen más a una sucesión de monólogos y argumentarios prefabricados que a una verdadera confrontación de opiniones y propuestas.

En las páginas que siguen discutiremos la conveniencia o no de estas ideas preliminares sobre la futura evolución y validez del formato debates electorales.

\section{Sistema de partidos y debates electorales}

Los debates electorales son un momento importante en el contexto de una campaña electoral. Si entendemos campaña como "un conjunto de decisiones estratégicas para conseguir el voto de los ciudadanos" (Martínez i Coma, 2008), entonces, los debates, como parte integrante de estas decisiones estratégicas, persiguen, ente todo, la maximización de las posibilidades de elección.

Esta concepción instrumental de los debates toma como punto de partida el interés del actor político en el acceso al cargo. Los debates electorales -entre otros muchos actos de campaña- no son sino un medio para conseguirlo. De ello deriva, también, la idea de que la celebración o no de debates dependerá de la utilidad que los actores cuenten en ellos para conseguir sus objetivos. 
De ahí que, a lo largo y ancho de la historia electoral española, desde la reinstauración de la democracia tras el final del franquismo (elecciones de 1977) hasta la actualidad, se hayan producido discontinuidades en la celebración de debates, tal y como analizaremos más adelante.

$\mathrm{Y}$ esto es así porque los debates electorales constituyen actos de campaña en los que interactúan los actores implicados, esto es, los principales partidos políticos y candidatos, con sus respectivas expectativas electorales. En este sentido, el análisis de la problemática de los debates electorales, sobre todo en lo tocante a su celebración o no, va unida a la información que circula en la campaña electoral.

Especialmente relevantes resultarán aquellos flujos que hacen referencia a las encuestas electorales, así como su difusión y comentarios en los principales medios de comunicación. O, dicho en palabras de Noelle-Neumann (1995), el "clima de opinión" que se va construyendo desde los medios hacia partidos, candidatos y ciudadanía y que constituye la principal materia prima para construir las expectativas electorales. Este clima de opinión será el que ofrezca pistas a partidos y candidatos sobre la conveniencia de celebrar o no debates.

\section{Debates: del bipartidismo al pluralismo moderado}

En un sistema de "bipartidismo imperfecto" ${ }^{13}$ " como el que rigió la interrelación partidista en España hasta las elecciones de 2015, normalmente, cuando a uno de los dos principales actores le interesaba celebrar un debate, al otro no. Este tipo de sistemas de partidos se parecen, en este sentido, a una moneda. Cuando sale cara, nunca sale cruz. Y viceversa. Se trata de una dicotomía excluyente. Un juego de suma cero.

\footnotetext{
${ }^{13}$ Entendemos bipartidismo al modo de Giovanni Sartori, esto es, el formato bipartidista no es tanto aquel en el que no existen terceras opciones políticas, sino aquel otro en el que "la existencia de terceros partidos no impide que los partidos principales gobiernen solos" (Sartori, 2005: 240). El apellido "imperfecto" lo utilizamos para indicar que el sistema incluye más de dos partidos.
} 
Pero, a partir de 2015, este juego de expectativas "a dos" se complica, reflejando, ni más ni menos, la también mayor complejidad parlamentaria. La irrupción de Podemos y Ciudadanos lo pone todo "patas arriba".

Se abre paso, entonces, una nueva interrelación "a cuatro" en la cual resulta mucho más probable que alguno de los actores intente introducir en la agenda de campaña la necesidad de celebrar un debate.

Por supuesto, este juego estratégico de cálculos electorales en torno a los debates debe ocultarse a ojos de la ciudadanía. En este intento, ella misma sirve de coartada. Por norma general, el partido o candidato interesado en un cara a cara con los otros tres propone un debate en nombre de los intereses de los votantes y la salud democrática del conjunto.

Los ciudadanos, se suele argumentar, tienen el derecho de escuchar directamente por boca de los candidatos la confrontación de propuestas y visiones políticas. Necesitan presenciar un careo, una lucha cuerpo a cuerpo para decidirse. Y ello sólo es posible a través de un debate.

Las hemerotecas de los periódicos están llenas de apelaciones de este estilo grandilocuente, en el que los intereses partidistas se disfrazan de intereses generales. Las elecciones generales de 2015 nos ofrecen un claro ejemplo de ello. Con la evidencia de las europeas de 2014 como telón de fondo ${ }^{14}$, las fuerzas emergentes -Podemos y Ciudadanosserían las más interesadas en la celebración de debates. Al fin y al cabo, estos actos de campaña sirven de carta de presentación ante el electorado para unos partidos y candidatos recién llegados.

Esta circunstancia enturbió, si cabe, un poco más la discusión sobre la celebración de debates en la campaña. Resultó evidente la tensión de intereses entre unas fuerzas emergentes que se sabía que iban a entrar

\footnotetext{
${ }^{14}$ En estas elecciones, celebradas el 25 de mayo de 2014, el partido político Podemos, creado dos meses antes, obtuvo unos excelentes y sorprendentes resultados: el 7,97\% de los votos (1.245.948) y 5 eurodiputados. Fuente: Ministerio del Interior de España.
} 
en el parlamento y unos partidos tradicionales -PP y PSOE- a la defensiva y, ciertamente, desorientados. Veamos algunos ejemplos.

En esta campaña, el líder de Podemos, Pablo Iglesias, pidió por carta a los demás candidatos, incluido el líder de Ciudadanos, Albert Rivera; un debate a cuatro argumentando la imperiosa necesidad de los ciudadanos de "contrastar las diferentes opciones políticas y las personas que aspiran a presidir el Gobierno del país"15.

Mientras tanto, el líder de Ciudadanos movía también ficha en el mismo sentido que Iglesias. La formación naranja, quizá de forma más acuciante que Podemos - que ya contaba con cinco eurodiputadosnecesitaba del debate para colocar en el mapa a su candidato y sus propuestas. Para diferenciarlo de la opción conservadora tradicional que representaba el PP. De ahí que Albert Rivera propusiese en la campaña celebrar un debate con los otros tres candidatos en un lugar neutral, la Academia TV ${ }^{16}$.

De entre los partidos tradicionales -el Partido Popular gobernante y el PSOE- fue el PP el que mostró un mayor rechazo a ampliar el formato de los debates, hasta el punto que Mariano Rajoy se negó a acudir a un debate a cuatro con Sánchez, Iglesias y Rivera, insistiendo en la repetición de los viejos modelos del "cara a cara" con el líder de la oposición.

Rajoy optaba así por obviar el cambio de tempo político y apostaba por lo que había sido la tónica en las dos anteriores elecciones (2008 y 2011): un debate "a dos" que dejase fuera a las fuerzas emergentes.

Cuando el PP se dio cuenta que el debate "a cuatro" corría el riesgo de convertirse en un debate "a tres", optó por una fórmula intermedia. Por un lado, se quería evitar el coste que supondría ausentarse de tal debate, pero, por otro, no se quería desautorizar la posición de Rajoy, contrario al nuevo formato. Ambas cuestiones intentaron armonizarse

\footnotetext{
${ }^{15}$ Expansión, 13/10/2015

16 "Albert Rivera reclama a la Academia de TV que organice un debate a cuatro con Pablo Iglesias, Rajoy y Pedro Sánchez” (El Mundo, 11/05/2015)
} 
enviando al debate a la vicepresidenta del Gobierno, Soraya Sáez de Santamaría.

El "moribundo" formato del "cara a cara" entre el presidente en busca de reelección y el líder de la oposición sería forzado, sin embargo, por el propio Rajoy y terminaría celebrándose una semana más tarde en la Academia TV.

Estaba clara la estrategia del Partido Popular: ningunear a los nuevos partidos, hacer como si no hubiese pasado nada, apostando por las viejas fórmulas del pasado. La intención era restringir el debate a un PSOE en franca decadencia, devorado no sólo por el PP (y Ciudadanos) en su lucha por el elector moderado, sino también por Podemos en el ámbito de la izquierda ${ }^{17}$.

El PSOE adoptó la estrategia del "debatir con todos, bajo todos los formatos". Pedro Sánchez, como acabamos de ver, asistió al debate a cuatro, bendiciendo, de alguna manera, las nuevas fórmulas de debate, que tendrían continuidad en 2016.

Pero el líder socialista dio, también, el gusto a Rajoy y se sentó a debatir con él en el tradicional "cara a cara" que el líder conservador llevaba pidiendo durante buena parte de la campaña electoral.

Se trataba del formato clásico inaugurado en 1993 (Felipe González contra José María Aznar) y que encontraría continuidad años después, en 2008 (Mariano Rajoy contra Zapatero) y 2011 (Mariano Rajoy contra Rubalcaba). Un formato, por cierto, muy criticado por su falta de frescura y naturalidad ${ }^{18}$.

${ }^{17}$ En estas elecciones de 2015 el PSOE perdió 20 diputados, aunque se mantuvo como principal partido de la oposición, evitando el tan temido sorpasso de Podemos. Tal posibilidad de pérdida de la condición de primer partido de la oposición volvería con fuerza a la discusión pública en la campaña electoral de 2016.

18 "Críticas hasta en el extranjero <<parece un debate de 1980>>" (20Minutos, $14 / 12 / 2015)$ 
El líder popular, que se enfrentaba por tercera vez a un rival del PSOE, terminaría desquiciando por los continuos ataques de que fue objeto por parte de su contrincante socialista ${ }^{19}$. Contrariamente a lo que pensaba el propio Rajoy, tal situación hubiese sido mucho más complicada en un debate a cuatro.

Quizá esta circunstancia y los resultados de 2015 (Podemos y Ciudadanos se habían convertido ya partidos parlamentarios) terminarían por empujar a Mariano Rajoy a aceptar el cambio de formato. En 2016 ya sí habría un debate "a cuatro" con todas las de la ley. Es decir, con los cuatro candidatos a la presidencia del Gobierno, sin segundas espadas de por medio.

\section{Podemos, Ciudadanos y los nuevos formatos de debate}

Resulta altamente probable que la irrupción de en un nuevo sistema de partidos con cuatro actores (Partido Popular, PSOE, Ciudadanos y Podemos) en vez de sólo dos esté jugando a favor de la institucionalización definitiva de los debates.

Desde la filosofía liberal-utilitarista se argumentaría que el egoísmo individual tan propio de los seres humanos y sus mundanas instituciones puede ser compatible con el bien común de la comunidad. Ello si y sólo si tales intereses particulares entran en feroz competencia los unos con los otros. En el fondo, este es el principal argumento de parte de la ciencia política norteamericana (Aldrich, 2012; Key, 1968; Przeworski, Stokes y Manin, 1999), capaz de encajar la ambición individual de las elites partidistas en un sistema social en el que los beneficiados seamos todos los ciudadanos.

Y no sólo de encajarla, sino también fomentarla. A mayor ambición y competencia por el poder -se argumenta- mayor probabilidad de que el sistema político representativo presente ante los ciudadanos buenas propuestas de gobierno.

19 "Pedro Sánchez consigue que Rajoy pierda los nervios por la corrupción del PP” (eldiario.es 15/12/2015) 
Si trasladamos esta visión a la problemática de los debates electorales, se puede entender que la posibilidad de celebrar o no un debate en función de las propias expectativas electorales de los representantes apuntan con mayor probabilidad hacia el bien común en un sistema de partidos ampliado.

Si el bipartidismo tiende hacia una concepción de la política como un "juego de suma cero", esto es, un lugar en el que quien gana lo gana siempre todo y quien pierde lo pierde siempre todo; es muy probable que las negociaciones que conducen hacia un debate se vuelvan muy difíciles. Más que nada, porque uno de los actores implicados en tales negociaciones suele no mostrar una voluntad real de celebrar el debate. Porque no le conviene. Si sólo existen dos partidos con posibilidades de gobernar, sólo a uno de ellos -el que va por detrás en las encuestassuele querer el debate.

Por supuesto, a esta circunstancia se le pueden poner todas las excepciones que deseemos. De alguna manera, los ya mencionados debates de 1993, 2008 y 2011 sí terminaron celebrándose, a pesar del sistema bipartidista imperante. Las condiciones sistémicas apuntan hacia una dirección, pero la realidad política puede, en muchas ocasiones, anularlas.

Podemos pensar en circunstancias excepcionales que terminaron haciendo posibles los debates. Todas ellas tienen que ver con un clima electoral de empate técnico, o, cuanto menos, de incumbent (o gobierno) amenazado con la expulsión del poder.

En 1993 el ejecutivo de Felipe González, en el gobierno desde 1982, experimentaba un claro proceso de desgaste tras varias elecciones ganadas por mayoría absoluta (1982, 1986 y 1989). A principios de la década de 1990 se abría, pues, la posibilidad de un cambio de gobierno por primera vez desde la reinstauración de la democracia. Esta circunstancia posibilitó que PSOE (gobierno) y PP (oposición) se pusiesen de acuerdo para que sus respectivos candidatos -Felipe González y José María Aznar- debatiesen, primero en Antena 3 (24 de mayo), y, una semana después, en Telecinco (31 de mayo). 
El caso del "cara a cara" de 2008 entre el presidente del gobierno desde 2004, el socialista José Luis Rodríguez Zapatero, y el popular Mariano Rajoy no está tan claro como los dos debates de 1993 ni como el de 2011, como veremos a continuación.

El catalizador del debate quizá pueda encontrarse en una cierta incertidumbre en el PSOE tras una legislatura presidida por la denominada "teoría de la conspiración" 20 y en un PP absolutamente abierto a los debates, por encontrarse en la oposición.

En 2011, Mariano Rajoy tuvo su tercera oportunidad de convertirse en presidente del Gobierno. Y, como suele decirse, a la tercera va la vencida. Las especiales circunstancias de estas elecciones hicieron que, con todo a su favor, el PP no se negase a debatir en un nuevo "cara a cara".

España y el mundo sufrían la mayor crisis económica desde el crack de 1929, José Luis Rodríguez Zapatero había adelantado elecciones por este mismo motivo y el ya ex presidente había decidido no optar a la reelección, cediendo el timón de un barco que se iba a pique a Alfredo Pérez Rubalcaba. Las encuestas anunciaban una rotunda mayoría absoluta para los populares, como así terminó sucediendo. Dentro de una clara estrategia de "salvar los muebles" el PSOE se mostró favorable al debate.

Podemos considerar que 1993, 2008 y 2011 constituyen la excepción que confirma la regla ya que, con anterioridad a 2011, sólo tres de las once elecciones generales celebradas contaron con debates televisados. Es decir, en el período 1977-2011 la relación no debates-debates fue de $27 \%-73 \%$.

\footnotetext{
${ }^{20}$ La teoría se refiere a la acusación de algunos medios de comunicación conservadores (la cadena radiofónica COPE y el periódico El Mundo, principalmente) y a parte del Partido Popular (el denominado "aznarismo") de falta de legitimidad en la victoria electoral del PSOE en 2004. El argumento se resume en el argumento de que el PSOE ganó las elecciones gracias al atentado de Madrid y la manipulación de decir el atentado fue cometido por el integrismo islámico. Durante la legislatura 2004-2008 estos medios de comunicación sembraron continuas dudas sobre la autoría de los atentados de Madrid, apostando siempre por la culpabilidad de la banda terrorista ETA.
} 
Pero la cosa podría empezar a cambiar, el tiempo lo dirá, a partir de las elecciones generales de 2015. Explicamos nuestra hipótesis recurriendo, una vez más, al sistema de partidos.

Cuando el sistema de partidos se abre a más actores (cosa que sucede en 2015) y la distancia entre la formación del gobierno y los votos ciudadanos se amplía merced a las negociaciones interpartidistas, existen más posibilidades de celebrarse debates.

Estos sistemas de partidos multipartidistas, que operan normalmente, además, en sistemas parlamentarios, se basan en la no siempre fácil negociación ${ }^{21}$. Los partidos más o menos cercanos ideológicamente se ponen de acuerdo para tomar las decisiones.

En los multipartidismos, que un actor disponga de los suficientes incentivos como para introducir en la agenda de campaña la necesidad de celebrar un debate electoral no implica necesariamente que el resto de actores se opongan a ello, como era la norma en el bipartidismo.

De este modo, disponemos de un elemento sistémico, por así decirlo, para afirmar que la España posterior a las elecciones generales de 2015 podría tener casi asegurada la celebración de debates electorales.

Hasta tal punto esto parece ser así que cuando el ex presidente del gobierno, el popular Mariano Rajoy, se negó a participar en diciembre de 2015 en un debate "a cuatro"; este debate, lejos de suspenderse, siguió en pie. La presión para que se celebrase era tal, que el Partido Popular no tuvo más remedio que aceptar una solución de compromiso, como hemos visto: Soraya Sáez de Santamaría.

Meses después el ex vicepresidente recapacitaría y, con la repetición de las elecciones en junio de 2016, ya sí se "animaría" a compartir debate con los otros tres candidatos antes mencionados.

\footnotetext{
${ }^{21}$ Nuestra impresión es que el sistema de partidos español, a partir de 2015, pasa de un bipartidismo (imperfecto) a un sistema de pluralismo moderado (Sartori, 2005: 224). El debate sobre si estamos en un pluralismo polarizado o moderado sigue abierto. Por cuestiones de espacio no es éste el lugar para abordarlo.
} 
Aunque este argumento basado en la competencia ampliada de expectativas no resulta, como casi todo en ciencias sociales, infalible; sí que parece apuntar hacia una consolidación de los debates en España.

Podríamos pensar, al contrario de lo que sucedía en el período 19772011 que acabamos de analizar, que la tendencia debería invertirse: la excepción no serían ya las elecciones con debate sino aquellas otras sin debate.

\section{Los formatos del debate: del "cara a cara" al debate "a cuatro"}

El horizonte que divisamos parece, por cuestiones sistémicas de tradición política y tecnológica, propicio para la generalización de debates electorales en su fórmula "a cuatro". Sin embargo, podríamos estar entrando en una situación paradójica que conviene meditar con detenimiento.

\section{1. ¿Quién gana aquí? ¿Cómo se organiza esto?}

Si bien los debates "a cuatro" podrían tener, como acabamos de ver, todas las papeletas para convertirse, por distintos motivos, en rutina electoral duradera; organizativamente, sin embargo, se vuelven mucho más complejos. $\mathrm{Y}$, desde el punto de vista periodístico, estos debates ampliados podrían estar perdiendo interés. Es decir, cuentan con una serie de resistencias que conviene tener en cuenta.

En un debate "a dos" la cosa está casi siempre clara: uno gana y otro pierde, trasladando al debate la lógica bipartidista a la que ya hicimos referencia. O pugilística: en una velada de boxeo siempre gana uno, o lo que resulta más mediático: siempre pierde uno. Aunque sea a los puntos.

Pero en los debates "a cuatro" quien pierde, puede no perder del todo, del mismo modo que el que gana no lo hace siempre de modo aplastante, ya que existe la posibilidad de que otro participante también gane un poquito. O que al que ataquen no le ataquen todos, o que los ataques se dirijan hacia varios frentes, difuminando intensidades. Las posibilidades se amplían hasta límites insospechados. 
Sin embargo, si la política en general y la campaña electoral en particular pueden entenderse como una especie de guerra civil sublimada (Lippmann, 2011), entonces, no cabe lugar a las medias tintas. Debemos medir el debate como se mide el mundo, con la existencia de vencedores y vencidos. De los que lo han hecho bien y han ganado y los que se han relajado, no han hecho sus deberes, se han preparado poco, $y$, consecuentemente, han perdido el enfrentamiento ${ }^{22}$.

Por si fuera poco, el tránsito de dos a cuatro participantes en los debates añade problemas de índole organizacional. No es lo mismo pactar temas a tratar, turnos de palabra, réplicas y contra réplicas, posiciones corporales, altura de las sillas, composición de los planos de cámara... cuando se trata de dos que cuando son cuatro los implicados. Cuatro, claramente, son multitud. Y no nos olvidemos, ya no negocian dos equipos, ahora son también cuatro.

El tiempo en televisión, como suele decirse, es oro. O, más exactamente, los argumentos, propuestas y ataques, deben reducirse a pequeños titulares de fácil manoseo e intercambio. Entre dos participantes, esta guerra de eslóganes y frases hechas, de ataques directos, de "cuerpo a cuerpo", pueden conjugarse con los condicionantes del medio televisivo. Pero cuando se trata de cuatro gallos en el corral, la extensión del debate y la poca claridad resultante (¿quién dijo qué? ¿Pablo Iglesias o Pedro Sánchez?) enturbian el lenguaje audiovisual.

Además, el simple traslado de la estructura de un debate pensado para dos a otro con cuatro protagonistas no parece funcionar. Resulta pesado, monótono y repetitivo. La negociación a cuatro equipos hace que la innovación de formatos y su adaptación a la nueva realidad multipartidista se vuelva harto complicada.

\footnotetext{
${ }^{22}$ Este "personaje" de doble cara lo ha desempeñado a la perfección el ex presidente socialista Felipe González en los debates de 1993: De perdedor por fatales circunstancias en el primer debate al 'happy ending' del segundo.
} 
Como estamos viendo, lo que parecía un futuro prometedor para las nuevas fórmulas de debate a cuatro, fruto de un sistema de partidos ampliado, renovado con el aire fresco de los nuevos partidos, puede estar volviéndose en su contra por motivos periodísticos y organizacionales.

\subsection{Los temas de debate del debate}

En teoría de agenda-setting suelen darse por ciertas dos cuestiones: Por un lado, se dice que el elemento clave en comunicación son los temas de debate que destacan los medios (McCombs y Shaw, 1972) y, por otro, la transferencia de importancia de estos issues desde la agenda mediática hacia la agenda pública ciudadana (McCombs, 2006).

Pues bien, los debates electorales, en su estructura actual, al menos en España, anulan ambas cuestiones, de modo que podemos pensar que su capacidad de influencia se ve bastante reducida. Y su utilidad para los ciudadanos, también.

Y ello se mantiene por mucho que hayamos pasado de los "cara a cara" a un enfrentamiento "a cuatro" porque, como acabamos de ver, la vieja estructura del debate tiende a permanecer.

Los debates electorales son un formato en el que los temas se pactan de antemano. Es decir, la pelea por la inclusión de unos temas u otros -madre de todas las batallas en una campaña electoral- queda excluida. Si en toda buena campaña parte del éxito de ciertos partidos y candidatos tiene que ver con la influencia en la configuración de la agenda mediática y, por añadidura, de los contenidos de la agenda pública (y personal), esto no sucede en los debates.

De ahí que, a veces, tengamos la sensación de que resultan poco interesantes y prefabricados. Como que les falta un componente de lucha verdadera. Ello se debe a que, por norma general, en los debates se pactan bloques temáticos que cubren la práctica totalidad del debate político (economía, política exterior, cuestiones sociales, etc.). 
Sin embargo, la realidad de una campaña electoral es bien distinta a este mundo pactado, consensuado y controlado de los debates electorales al uso. Cada vez más, la clave de la comunicación política tiene que ver con la lucha no tanto en los temas (como sucede en los debates) sino sobre los temas. Este razonamiento parte de la vieja idea de McCombs de que ciertos temas "tienen dueño" (ibíd.).

Si esto es así, se abre un dilema que, sin que sirva de precedente, parece tener fácil solución. Un partido o candidato tiene que ganar, sobre todo, en el terreno de la introducción de los temas en los que es percibido como fuerte. Por poner ejemplos tradicionales: los partidos de derecha suelen estar muy interesados en cuestiones como la economía o la seguridad ciudadana y los de izquierda en la ampliación de derechos o cuestiones sociales.

Pero, si esta batalla queda excluida, como sucede en los debates electorales pactados al milímetro, y de lo que se trata es de debatir (encuadrar) en pie de igualdad todos los temas, se entiende que la autenticidad de tal debate se resienta.

Volvamos otra vez a esa visión utilitarista de la política que utilizábamos al principio del capítulo. Parece lógico que, dentro de las farragosas negociaciones conducentes a la celebración de un debate electoral, la selección de temas ocupe un lugar importante. Si esto es así, ningún candidato aceptaría no hablar, por ejemplo, de corrupción dentro de un gobierno acosado en los tribunales o ningún gobierno aceptaría no hablar de economía en un ciclo económico expansivo.

Por ello, los debates electorales parten con desventaja. Son contrarios a la lógica dominante en las campañas electorales de nuestros días. Se convierten en una guerra con batallas demasiado acotadas. Cuando, lo normal es que los escenarios de la confrontación conformen la propia confrontación.

De ahí que muchos debates se conviertan en una sucesión de repeticiones monótonas tirando de argumentario. Y de ahí también que, cada vez más, los equipos de asesores prefabriquen y anticipen 
encuadres y argumentos de ataque del rival o rivales cuando el tema no resulta especialmente favorable al candidato.

Los debates se transforman así en algo previsible y rutinizado. Pactado hasta el extremo. El acuerdo no sólo se produce entre partidos para que se traten ciertos temas por encima de otros. Ese pacto se alcanza también de puertas hacia dentro, entre el candidato y sus asesores que todo lo estudian hasta la extenuación. Preparando encorsetadas contrarréplicas porque ya se sabe qué temas se van a tratar y durante cuánto tiempo.

En resumen, cuando la composición temática de un debate es conocida de antemano por los actores, la autenticidad desciende y la artificiosidad aumenta.

Cosa bien distinta sucede en aquellos otros debates en los que los temas no han sido pactados y dependen de la creatividad de los debatientes, del público asistente en la sala y sus impertinentes preguntas, de las redes sociales de sacan punta a todo, o de un equipo de polarizados periodistas allí reunidos.

Son fórmulas a estudiar, pero, todas ellas, tienen como objetivo escudriñar la posición verdadera del candidato hacia un tema sobre el que se pasa de puntillas. Porque, evidenciar que se trata de una cuestión a la que no se le da la más mínima importancia constituye, también, y, sobre todo, una rica fuente de información para los ciudadanos.

La improvisación de Mariano Rajoy sobre medio ambiente y las referencias a su primo ${ }^{23}$ dejan bien a las claras que no se trataba de una cuestión prioritaria ni para él ni para su partido. Esta circunstancia sirve de toque de atención a todos aquellos votantes interesados en

${ }^{23}$ En el año 2007 Rajoy se mostraba bastante poco preocupado por el verdadero alcance del calentamiento global. Y, para argumentar su escepticismo, no se le ocurrió otra cosa que improvisar una respuesta sincera (no aconsejada por su equipo) y asegurar que un primo suyo, catedrático de Física en la Universidad de Sevilla, le había dicho que no era posible predecir "ni el tiempo que va a hacer mañana en Sevilla", dando a entender que las previsiones del cambio climático en el planeta tierra eran ciertamente alarmistas y, quizá, infundadas (Cadena Ser, 22/10/2007). 
cuestiones medioambientales, para los cuales el PP no parecía su mejor opción de voto, al menos en 2007.

Sin embargo, Rajoy o cualquier otro candidato que haya sido avisado, y, sobre todo, entrenado por un equipo de asesores sobre un tema a debatir ante las cámaras con los demás cabezas de cartel, siempre puede salvar los muebles. No será tan evidente que el medio ambiente no constituya, ni de lejos, su prioridad de gobierno, ya que no tiene ni idea sobre ello.

Pero, aunque de manera un tanto artificial, en el debate de turno, será capaz de hilvanar la política genérica del Partido Popular en materia de medio ambiente. Para muchos ciudadanos su postura sobre el calentamiento global podría no ser percibida como un área de debilidad.

Un artículo publicado por el diario El Mundo en 2015 mostraba el radical cambio de opinión del ya presidente Rajoy. Aconsejado por expertos y asesores de su propio partido, olvidó las indicaciones de su primo catedrático y se refirió al cambio climático como "el mayor reto medioambiental" ${ }^{24}$.

Este tipo de meteduras de pata, fruto de la vida misma, de la naturalidad con la que, ya pocas veces, se vive la política y la postura en ciertos temas de debate; está ausente de los debates electorales. Convertidos en una serie de monólogos temáticamente pre configurados con posiciones, réplicas y contra réplicas ensayadas mil veces. Repetidas frente al espejo como un mantra sin sentido. $\mathrm{Y}$ eso se nota.

De ahí que, para muchos ciudadanos, los debates cada vez resulten menos interesantes o, cuanto menos, apenas les aporten información nueva para decidir su voto. $\mathrm{Y}$, de ahí también, que algunos medios de comunicación comiencen a alzar su voz reclamando nuevos formatos más frescos y dinámicos.

24 "El cambio climático de Rajoy: del negacionismo de su primo al mayor reto medioambiental” (El Mundo, 20/11/2015) 
No se trata tanto de fomentar el morbo ante la posibilidad de que nuestros políticos se equivoquen o digan tonterías. Todos lo hacemos. Tiene más que ver con discernir cuándo un candidato tiene las cosas claras y la brújula política orientada hacia el norte. Y cuándo no. Porque resulta muy indicativo de las distintas prioridades que tienen unos partidos frente a otros.

Y, en la medida en que los ciudadanos también disponemos de diferentes prioridades, lo ideal es que podamos alinearlas de forma más auténtica con aquellos partidos más acordes con nuestro mundo interno.

\section{En conclusión... una de cal y una de arena}

Contemplamos la posibilidad de la existencia de dos fuerzas contradictorias en la problemática que rodea a la celebración de debates electorales en período electoral.

La primera de estas contradicciones podría estar empujando hacia el cambio en los debates electorales. Esto es, una evolución desde los "cara a cara" hacia los debates "a cuatro". La otra tendría que ver con una serie de insuficiencias en la razón de ser de los debates que sugieren la necesidad de profundizar en la renovación del formato de los debates.

Las razones por las que pensamos que los debates tradicionales ("a dos" o "cara a cara") podrían estar cayendo en el olvido se relacionan, a su vez, con dos cuestiones relacionadas con el sistema político.

La primera de ellas hace referencia al cambio del sistema de partidos anticipado en las elecciones europeas de 2014 y sucedido en las generales de 2015. La transición desde un sistema de partidos de "bipartidismo imperfecto" hacia otro caracterizado por un mayor pluralismo supone un paso de dos a cuatro partidos importantes. En futuras investigaciones quedará por determinar si la fórmula se detiene en estos cuatro participantes o se extiende, como parece posible, a un quinto actor: el partido ultraderechista Vox. 
Ello no sólo afecta al propio sistema de partidos, la vida parlamentaria y la formación de gobiernos. También lo hace, como no podría ser de otra forma, a la comunicación política en general y a los debates electorales en particular.

Como demuestra la polémica surgida en las elecciones de 2015 y su repetición en 2016, los debates, en esta nueva era de fractura del bipartidismo, parecen apuntar hacia los debates "a cuatro".

Por otro lado, también sopesamos la posibilidad de que el hecho de que desde las elecciones de 2008 se hayan celebrado debates electorales bajo diferentes fórmulas ("a dos" en 2008 y 2011, “a cuatro" en 2015 y 2016) podría estar convirtiéndolos ya en una tradición política que, por pura inercia, podría consolidarlos.

Sin embargo, estos debates "a cuatro" introducen nuevos desafíos e incertidumbres que podrían amenazar su propia existencia en el corto y medio plazo. El paso de una confrontación directa (dos debatientes) a otra más difusa (cuatro) podría contener un menor interés político y periodístico. No queda del todo claro que haya que incluir también aquí a la ciudadanía.

En un debate "a dos" uno de los participantes (casi siempre) gana y el otro (casi siempre) pierde. Pero, ¿qué sucede en un debate a cuatro? La respuesta no parece nada clara. Estas cuestiones, además, pueden afectar también al interés de los ciudadanos. Habrá que comprobarlo en futuras elecciones, máxime cuando la propia fórmula "a cuatro" podría estar ampliándose hacia la de "a cinco" con la irrupción del partido político Vox a finales de 2018.

Estos debates electorales ampliados implican, por otro lado, un mayor esfuerzo organizativo y un encaje algo más conflictivo en el medio televisivo. Ya se sabe que la televisión es un lugar en el que prima la personificación, la sencillez, el slogan y el enfrentamiento. Pasar de dos a cuatro debatientes podría alargar tiempos y desdibujar estas tendencias. 
Por último, los debates (tanto "a dos" como "a cuatro") limitan la batalla por los temas de debate, centrándose casi por completo en la lucha en los temas de debate. Mientras la buena parte de la comunicación política de una campaña se centra en establecer de qué se habla, los debates renuncian a ello al establecer bloques temáticos cerrados sobre los que se va a debatir mediante la negociación entre partidos, algo que resta naturalidad al formato, limita la emergencia de contradicciones entre los participantes e impide la autenticidad del debate político.

Sólo una reforma profunda y creativa en el formato de los debates podría adaptarlos a las dinámicas actuales de una sociedad española inmersa en procesos de cambio muy importantes. A ello se une también una comunicación política que ofrece muchas más posibilidades que las que hasta el momento han sido utilizadas.

\section{Bibliografía}

Aldrich, J. H. (2012). ¿Por qué los partidos políticos? Una segunda mirada. Madrid: CIS.

Key, V. O. (1968). The Responsible Electorate. Rationality in Presidential Voting 1936-1960. Cambridge: Harvard University Press.

Lippmann, W. (2011). El público fantasma. Madrid: Genueve Ediciones. Martínez i Coma, F. (2008). ¿Por qué importan las campañas electorales? Madrid: CIS.

McCombs, M. (2006). Estableciendo la agenda. El impacto de los medios en la opinión pública y en el conocimiento. Barcelona: Paidós.

McCombs, M. y Shaw, D. (1972). "The Agenda-Setting Function of Mass Media". The Public Opinion Quarterly, 36(2).

Noelle-Neumann, E. (1995). La espiral del silencio. Opinión pública: nuestra piel social. Barcelona: Paidós.

Przeworski, A. S., Stokes.B, y Manin, B. (1999). Democracy, Accountability and Representation. New York: Cambridge University Press.

Sartori, G. (2005). Partidos y sistemas de partidos. Madrid: Alianza. 


\section{Reconocimiento de la investigación}

Este capítulo forma parte de los trabajos desarrollados en el marco del proyecto de I+D+I (Retos) "DEBATv, Debates Electorales Televisados en España: Modelos, Proceso, Diagnostico y Propuesta" (Ref. CSO2017-83159-R), financiado por el Ministerio de Economía, Industria y Competitividad (MINECO), la Agencia Estatal de Investigación (AEI) y el Fondo Europeo de Desarrollo Regional (FEDER) de la Unión Europea (UE). 



\title{
En el exoesqueleto: la preproducción de la campaña electoral
}

\author{
Fermín Galindo Arranz \\ Universidad de Santiago de Compostela \\ Juan Carlos Regueira Rey \\ CRTVG
}

\begin{abstract}
PARA CITAR: Galindo, F. y Regueira J. (2019). "En el exoesqueleto: La preproducción de la campaña electoral". En Conde-Vázquez, E., Fontenla-Pedreira, J. y Rúas-Araújo, J. (Eds.), Debates electorales televisados: del antes al después (pp. 49-65). Cuadernos Artesanos de Comunicación, cac 154. La Laguna (Tenerife): Latina. DOI: $10.4185 /$ cac154
\end{abstract}

\section{Resumen}

El mundo de la política conoce el alcance de la persuasión televisiva y se afana por utilizar el medio de la mejor manera posible para sus intereses. Si bien es cierto que la televisión se convierte en la arena a la que se traslada la lucha parlamentaria en los periodos electorales, la dialéctica de los debates electorales no es ajena a los principios generales en los que se desarrolla una comunicación política hiperregulada en tiempo de campaña. Al conjunto de normativas que condicionan el tratamiento televisivo de la información política la hemos denominado exoesqueleto informativo, ya que se da la paradoja de que las mismas normas que limitan la agilidad informativa permiten que esta se produzca a partir de un consenso basado en el arbitraje y la jurisprudencia anterior.

Palabras clave: Televisión, debates electorales, exoesqueleto informativo, información política, preproducción, marco jurídico. 


\section{En el exoesqueleto}

T A televisión se convierte en la arena a la que se traslada la lucha Larlamentaria en los periodos electorales. Al abordar el tratamiento diferenciado del mensaje televisivo durante los periodos electorales, Roglan y Equiza (1996:133) explican la dificultad de una "codificación mucho más compleja que la del resto de los temas informativos y siempre linda al borde de la persuasión" y remiten a la clásica diferenciación entre objetividad y verdad de Walter Lippman (1965: 226), para quien no eran lo mismo y se debían distinguir con mucha claridad. "La función de las noticias es señalar un hecho, la función de la verdad sacar a la luz los hechos escondidos para situarlos en relación con todos y realizar una imagen de la realidad sobre la que el hombre pueda actuar". Tarea imprescindible desde el punto de vista informativo, pero realmente difícil en períodos electorales en los que abundan el ruido, la propaganda y la intoxicación.

La dialéctica de los debates electorales no es ajena a estos principios generales en los que se desarrolla una comunicación política hiperregulada en tiempo de campaña. Al conjunto de normativas que condicionan el tratamiento televisivo de la información política la hemos denominado exoesqueleto informativo, ya que se da la paradoja de que las mismas normas que limitan la agilidad informativa permiten que esta se produzca a partir de un consenso basado en el arbitraje y la jurisprudencia anterior. Esta regulación exhaustiva presenta graves inconvenientes desde el punto de vista informativo, no así desde el punto de vista de la producción y no digamos ya de la pre-producción.

La maquinaria electoral televisiva, ya de por sí compleja, requiere de un despliegue técnico de enormes dimensiones para poder alcanzar todos los puntos de interés y concentrar la atención de la sociedad en un entorno extraordinariamente competitivo y en el que se trabaja en tiempo real. La improvisación no cabe en la producción televisiva, así que la experiencia jurisprudencial acumulada en anteriores comicios resulta de vital importancia para alcanzar una cobertura informativa de calidad. Este esfuerzo requiere una movilización importante de todo tipo de recursos, cuyo altísimo coste se ha llegado a establecer en el entorno del uno por ciento de su presupuesto anual (Galindo y 
Regueira, 2018: 110) en el caso de las televisiones públicas. A continuación, pasaremos a ver las ventajas que, desde el punto de vista de la producción televisiva, encierran este tipo de dinámicas, muy criticadas desde el punto de vista informativo, pero realmente prácticas cuando se trata de ofrecer un servicio público esencial como la cobertura informativa de una campaña electoral y, en especial, los grandes debates electorales, elemento central y decisivo de la política actual.

\section{De la previsión a la emisión}

El entramado legislativo y normativo que articula el tratamiento informativo de los procesos electorales arranca de la Constitución y se ha ido actualizando en las distintas convocatorias electorales a partir de las sentencias de las Juntas Electorales. Arnaldo-Alcubilla y DelgadoIribarren (2009: 21), expertos en este ámbito, explican en su libro, Código electoral, los orígenes de la normativa: "El control plenamente judicial de las elecciones se establece ya en el Real Decreto-ley de 18 de marzo de 1977, que cubrió adecuadamente una primera etapa de la transición democrática, y en el que se encargaba su organización a unas Juntas, Central, Provinciales y de Zona, en las que estarán presentes Magistrados y Jueces que asumen la presidencia y dirección de dichas Juntas. Y se consagra como consecuencia de la instauración del Estado social y democrático de derecho por la Constitución de 1978, que propugna como valores superiores de su ordenamiento jurídico la igualdad y el pluralismo político y que provee al proceso electoral de un control estrictamente judicial que asegura la defensa de la legalidad en toda su extensión.

En su cumplimiento, la vigente Ley Orgánica del Régimen Electoral General LOREG de 19 de junio de 1985 —nacida con vocación de Código Electoral - acentúa la composición judicial de las Juntas, erigidas así en órganos esenciales de la administración electoral, que gozan de la máxima independencia, tanto frente a la Administración ordinaria, como frente a las diversas fuerzas políticas en lucha, y a las que incumbe garantizar la transparencia y objetividad del proceso electoral velando por el cumplimiento de lo dispuesto en la normativa jurídica que lo regula. La filosofía de la ley de 1985 persigue — como 
se expresa en su preámbulo- el objetivo primordial de que las decisiones políticas en las que se refleja el derecho de sufragio se realicen en plena libertad [...] Su contenido se ordena en disposiciones generales de aplicación en todo proceso electoral, y normas [referidas] a los diferentes tipos de elecciones [...] [que permiten], no sólo su desarrollo, sino incluso su modificación o sustitución en muchos de sus extremos por la actividad legislativa de las Comunidades Autónomas".

A la hora de plantear la cobertura de cualquier campaña electoral, las cadenas de televisión, públicas y privadas, han de asegurarse de contar con un asesoramiento jurídico que tenga en cuenta las últimas resoluciones dictadas por los órganos competentes. Las televisiones públicas están sujetas a un escrutinio legal particularmente escrupuloso, por lo que sus departamentos jurídicos se encargan de proponer la aplicación de estas pautas en el marco de la LOREG, de la Constitución y de la doctrina emanada de la Junta Electoral Central en relación a la actuación de los medios de comunicación públicos. "Junto a los derechos consagrados por el artículo 20.1 CE, ésta en su apartado 3, garantiza el acceso de los grupos políticos significativos a los medios de comunicación de titularidad pública respetando el pluralismo de la sociedad, previsión constitucional que tiene su instrumento a nivel legal orgánico en el artículo 66 LOREG, cuyos principios han de presidir la actuación en período electoral de los medios de titularidad pública y de las emisoras privadas de televisión".

El enunciado del artículo 66 de la Ley Orgánica 5/1985 de 19 de junio de Régimen Electoral General LOREG: "El respeto al pluralismo político y social, así como la neutralidad informativa de los medios de comunicación de titularidad pública en período electoral, serán garantizados por la organización de dichos medios y su control previstos en las Leyes. Las decisiones de los órganos de administración de los referidos medios en el indicado período electoral son recurribles ante la Junta Electoral competente [...] según el procedimiento que la Junta Electoral Central disponga".

La ley contiene varios artículos más que hacen referencia a los medios de comunicación. En todos ellos se defiende de forma expresa el 
pluralismo y la neutralidad. El artículo 66 recoge los criterios que limitan la publicidad electoral en los medios públicos y regulan el acceso de los partidos a los espacios gratuitos de propaganda electoral. A lo largo de las últimas décadas este género político ha ido evolucionando, pasando de los largos discursos iniciales a cámara a impecables spots de acabado publicitario que buscan targets y públicos objetivos, así como la viralización en redes sociales.

Artículo 60

1. No pueden contratarse espacios de publicidad electoral en los medios de comunicación de titularidad pública.

2. Durante la campaña electoral los partidos, federaciones, coaliciones y agrupaciones que concurran a las elecciones tienen derecho a espacios gratuitos de propaganda en las emisoras de televisión y de radio de titularidad pública conforme a lo establecido en los artículos siguientes.

La normativa electoral ha evolucionado en paralelo a la del propio género político. Pero no todas las formaciones políticas cuentan con los mismos medios y el mismo know-how, de lo que se desprende la necesidad de los medios públicos de atender desde los medios más básicos de producción a atender las demandas más sofisticadas y de última generación. [...] La distribución de espacios gratuitos para propaganda electoral se hace atendiendo al número total de votos que obtuvo cada partido, federación o coalición en las anteriores elecciones equivalentes.

Artículo 65

1. La Junta Electoral Central es la autoridad competente para distribuir los espacios gratuitos de propaganda electoral que se emiten por los medios de comunicación públicos cualquiera que sea el titular de los mismos, a propuesta de la Comisión a que se refieren los apartados siguientes de este artículo.

2. La Junta Electoral Central puede delegar en las Juntas Electorales Provinciales la distribución de espacios gratuitos de propaganda 
electoral en las programaciones regionales y locales de los medios de comunicación de titularidad estatal y de aquellos otros medios de ámbito similar que tengan también el carácter de públicos. En este supuesto, se constituye en dicho ámbito territorial una Comisión [...] con una composición que tenga en cuenta la representación parlamentaria en el Congreso de los Diputados del ámbito territorial respectivo. Dicha Comisión actúa bajo la dirección de la correspondiente Junta Electoral Provincial.

El texto se adaptó a las televisiones privadas en la Ley Orgánica 2/1988 de 3 de mayo: "El respeto al pluralismo y a los valores de igualdad en los programas difundidos durante los períodos electorales por las emisoras de televisión privada objeto de concesión quedarán garantizados por las Juntas Electorales en los mismos términos previstos en la legislación electoral para los medios de comunicación de titularidad pública". No obstante, las televisiones privadas no están sometidas a la obligación legal de ceder espacio en su programación a los grupos políticos para la emisión de espacios gratuitos de propaganda electoral, exención confirmada por la Junta Electoral Central en su Acuerdo de 23 de febrero de 1996.

La emisión de los canales públicos está sometida además a sus propias leyes de creación. La TVG, además de la LOREG y la doctrina de las Juntas Electorales debe atenerse a la ley 9/1984, de 11 de julio, de creación de la CRTVG (Compañía de Radio Televisión de Galicia); a la ley 4/1980, de 10 de mayo, en relación al Estatuto da Radio e da Televisión y la ley 46/1983, de 26 de diciembre, reguladora del tercer canal de televisión. Este ordenamiento se traduce en que las televisiones públicas deben propiciar el acceso de los grupos políticos significativos a los medios de comunicación de titularidad pública. En este sentido, el Consello de Administración de la Compañía de Radio Televisión de Galicia CRTVG establece el tratamiento mediante un plan de cobertura específico en cada convocatoria electoral. Este documento regula todo lo relativo a los espacios gratuitos de propaganda electoral y a la "difusión de campañas institucionales, programas especiales de comienzo y cierre de campaña, así como los debates y entrevistas a candidatos, junto a la cobertura diaria en los espacios informativos". 
A partir de esta práctica continuada en el tiempo se produce lo que se ha denominado Ley D’Hont de la Televisión (Galindo: 1998, 93). El sistema electoral proporcional condiciona de forma decisiva a los votantes a utilizar su voto en apoyo de mayorías políticas, y castiga la expresión de una realidad política más plural, especialmente en las pequeñas circunscripciones. La existencia de mecanismos unificadores dentro del propio sistema se ve acrecentada por el acceso a los consejos de administración y a la reiterada asignación de espacios de propaganda a partir de los resultados de anteriores comicios. En consecuencia, se produce un efecto de reiteración de sesgos inherentes a la aplicación de la LOREG. Con el fin de compensar esta situación, la Junta Electoral Central se ha tenido que pronunciar (Instrucción 1/2015 de 15 de abril de 2015) para dar cabida a nuevas formaciones emergentes carentes de representación política anterior y que "en recientes procesos electorales y en el ámbito territorial del medio de difusión, hayan obtenido un número de votos igual o superior al 5\% de los votos válidos emitidos".

\subsection{Emisión de espacios de propaganda electoral}

Con anterioridad al comienzo de la campaña electoral, el Consello de la $C R T V G$ propone un calendario vinculante con el reparto de tiempos de los espacios gratuitos de propaganda electoral a incluir en la parrilla de la programación, que han de ser aprobados a posteriori por la Junta Electoral Provincial. Los criterios de reparto están fijados en la LOREG. En su artículo 64 se establece un baremo orientativo de "distribución del tiempo gratuito de propaganda electoral en cada medio de comunicación de titularidad pública y en los distintos ámbitos de programación que estos tengan”.

La asesoría jurídica propone en cada convocatoria una tabla de aplicación concreta de la pauta marcada por la ley, en el que se traslada de forma habitual una proporcionalidad establecida a partir de los últimos resultados electorales. La duración de cada uno de estos espacios ha ido disminuyendo con el paso del tiempo y en la actualidad no suelen superar los treinta segundos. 


\subsection{Emisión de publicidad institucional}

A partir de un Acuerdo de la Junta Electoral Central de 1995 no se pueden realizar campañas institucionales en periodo electoral (Arnaldo-Alcubilla y Delgado-Iribarren, 2009: 283). Esta doctrina parte de la reforma de 1994 del artículo 50 de la LOREG:

Artículo 50

1.- Los poderes públicos que en virtud de su competencia legal hayan convocado un proceso electoral pueden realizar durante el período electoral una campaña de carácter institucional destinada a informar a los ciudadanos sobre la fecha de la votación, el procedimiento para votar y los requisitos y trámite del voto por correo, sin influir, en ningún caso, en la orientación del voto de los electores. Esta publicidad institucional se realizará en espacios gratuitos de los medios de comunicación social de titularidad pública del ámbito territorial correspondiente al proceso electoral de que se trate, suficientes para alcanzar los objetivos de esta campaña.

A veces, los acuerdos de los órganos competentes en período electoral pueden resultar sorprendentes. Así, para la Junta Electoral Central no se pueden realizar campañas promoviendo el voto ya que, tras la modificación del artículo 50, entiende que no cabe la incentivación del voto, pues la abstención es una opción tan legítima como el ejercicio del derecho de sufragio.

A lo largo del tiempo, por tanto, se ha ido acotando la presencia de publicidad institucional en periodos electorales, sujeta a tres limitaciones fundamentales. La primera, en cuanto al sujeto de la campaña institucional: sólo cabe realizar la campaña institucional a que se refiere el artículo 50.1 por el poder público que haya convocado el proceso electoral. Una segunda, sobre el límite temporal, ya que no cabe realizar campaña institucional el día anterior al de la celebración de las elecciones, el llamado día de reflexión. Y, una tercera, sobre los medios de emisión de la campaña institucional que debe hacerse en espacios gratuitos de los medios de comunicación de titularidad pública 
del ámbito territorial correspondiente al proceso electoral de que se trate (Arnaldo-Alcubilla y Delgado-Iribarren, 2009: 281).

En condiciones normales, el plan de cobertura de las próximas elecciones al Parlamento Europeo de 2019, así como el resto de los comicios simultáneos, puede contar con tres campañas institucionales sucesivas. Una primera, en la que se informa a los electores sobre la exposición pública del censo electoral. A continuación, otra sobre la solicitud y plazos para ejercer el voto por correo y, por último, una campaña final anunciando el día y procedimiento de votación objeto de la campaña: tipos de papeletas, colores, urnas, horarios de votación o rutinas electorales, entre otros extremos.

\section{La preproducción de un gran debate}

Un debate televisivo en prime-time entre los principales líderes políticos de una contienda electoral es un espacio estrella en términos de presupuesto, por lo que la preparación del operativo de producción requiere de un gran esfuerzo de personal, equipo técnico e inversión económica. El diseño de este operativo es lo que, en términos profesionales, se denomina preproducción. En esta etapa, el equipo editorial acuerda los objetivos estéticos y formales de la propuesta programática y, a continuación, los jefes de equipo de la televisión cuantifican el esfuerzo de producción en términos económicos, temporales y de personal.

En cuanto al contenido, la primera pata de la etapa de preproducción audiovisual, las similitudes con cualquier otro programa de máxima audiencia acaban ahí, ya que, al tratarse de un espacio electoral, los condicionantes aportados por la legislación expuesta con anterioridad son de aplicación y han de ser respetados escrupulosamente. Al tratarse de una televisión pública, la TVG está obligada a ceñirse a la versión más exigente de dicha legislación. Es entonces cuando dichos condicionantes -el exoesqueleto informativo al que hacemos referencia- demuestran su efectividad, ya que permiten a la superestructura televisiva concentrarse en aprovechar de la manera más eficiente la infraestructura con la que cuenta, todo ello en términos estrictamente profesionales y de efectividad en cuanto a la audiencia, 
acotados por el corpus jurisprudencial la mayoría de factores externos relativos al contenido.

Podemos sintetizar las acciones de preproducción en seis pasos previos, relativos tanto a los aspectos prácticos del debate y la mecánica de su desarrollo, como a los elementos estéticos consustanciales a la espectacularización de lo que, en términos formales, es un evento puramente televisivo que, como todo relato, contará con la estructura clásica de planteamiento, nudo y desenlace.

\subsection{E1 tiempo es oro}

En el caso del debate emitido por la Televisión de Galicia en 27 de febrero de 2008, la televisión autonómica lo propuso en el contexto de las elecciones generales y andaluzas del 9 de marzo. Al tratarse de unas elecciones generales, la legalidad vigente obligaba a que la propuesta de la TVG incluyese a las tres formaciones con representación institucional. Según la legislación y la normativa vigentes, la asignación de tiempos debía ser proporcional a esta representación en la cámara baja. Este fue el criterio seguido para la propuesta que las tres fuerzas políticas presentes en la cámara estatal aceptaron y que posibilitó que debatiesen ante las cámaras Emilio Touriño, Alberto Núñez Feijóo y Anxo Quintana, cabezas de cartel de PSdeG-PSOE, PPdeG y BNG, respectivamente.

El primer objetivo a considerar en la etapa de preproducción era una solución técnica que permitiese garantizar el más escrupuloso respeto a la asignación de tiempos. Para ello, la TVG encargó a la portuguesa wTvision - proveedor de la solución tecnológica de realidad aumentada del especial de los comicios municipales del 27-M de 2007- el diseño de una aplicación informática específica para este fin. La misma debía ir sumando los minutos y segundos consumidos por cada líder en sus intervenciones para indicarles cuándo debían finalizar las mismas. El cómputo era público y debía de ser mostrado de manera clara a los líderes en sus sucesivos turnos de intervención. Para ello, la aplicación incluía un diseño gráfico específico con los tiempos consumidos que eran mostrados en tres pantallas, una por líder, claramente visibles para los intervinientes. 
Esta exigencia planteaba retos que hubo que solucionar de manera coordinada por los respectivos responsables de realización y escenografía. Objetivo: facilitar al máximo la lectura de tiempos a los líderes presentes, sin que la ubicación de las pantallas interfiriese en la imagen ofrecida a los espectadores, tanto en los planos generales, como, sobre todo, en primeros planos y tomas cerradas. Un tercer criterio a tener en cuenta era la dirección de la mirada y la postura corporal de los candidatos; ambas debían ser lo más naturales posible, sin que la ubicación de la pantalla adjudicada a cada líder los obligase a desviar de manera excesiva la mirada o a girar el cuerpo de manera forzada para comprobar en la pantalla cuánto tiempo les restaba en cada intervención.

Las propuestas de los profesionales del canal autonómico fueron comprobadas in situ por los respectivos responsables de imagen de cada líder, con los que se pactaron ubicaciones y planos para tratar de alcanzar la mayor similitud estética posible entre los planos de los tres intervinientes, de manera que los factores formales no fuesen una distracción respecto del contenido de sus propuestas. La negociación con los interlocutores de los partidos llevó a ciertas modificaciones menores, lo cual permitió acomodar sus sugerencias y hacer que los candidatos se sintiesen más cómodos, todo ello sin alterar de manera significativa el diseño estético global decidido en la preproducción del debate.

El cronometraje de tiempos es un factor decisivo en la mecánica del debate y entronca directamente con las directrices legales, dado que cada candidato ha de disponer de un tiempo proporcional a su presencia en la cámara correspondiente. Para ello, es necesario aplicar el máximo cuidado en el cómputo de los tiempos empleados en sucesivos turnos por cada interviniente, cálculo que debe hacerse en tiempo real para que el moderador pueda ir ajustando al segundo la duración de las intervenciones. Sólo así es posible garantizar que, finalizado el debate, cada candidato haya dispuesto de los tiempos que aritméticamente le corresponden $y$, con ello, evitar posibles reclamaciones de las fuerzas políticas que puedan sentirse perjudicadas 
por un cómputo deficiente de los tiempos otorgados por el moderador a cada candidato.

Al tratarse de un elemento prioritario, el canal autonómico decidió implementar —en paralelo a la solución informática — una alternativa más artesanal que sirviese de respaldo en previsión de que aquella fallase. La importancia de un debate de estas características y su posible impacto en las decisiones de los votantes hacía aconsejable tal previsión. Se preparó una sala con tres cronometradores, uno por líder, que realizaban un cómputo manual de la duración de sus intervenciones. Una cuarta persona informaba por un canal interno a través del correspondiente pinganillo al moderador, lo cual le permitía reconducir los turnos cuando era preciso realizar pequeños ajustes.

\subsection{Localizaciones y escenarios}

Con anterioridad a 2008, la autonomía gallega sólo había asistido a un debate con las características propias de un gran acontecimiento televisivo. Había sido un cara a cara con los cabezas de cartel de PPdeG y PSdeG-PSOE, Manuel Fraga Iribarne y Antolín Sánchez Presedo, emitido por Antena 3 con ocasión de las autonómicas de 1993. El del 27-F era, por tanto, el primer gran debate a emitir por la TVG. La ocasión exigía una localización acorde con la singularidad del evento. Se decidió ubicar el debate en un entorno histórico y el escenario elegido fue el claustro cubierto del hotel San Francisco, en Santiago de Compostela. La ubicación aportaba una cierta espectacularidad visual que no excedía la contención formal necesaria para un evento de estas características.

Las intervenciones estéticas aportadas a la localización incluyeron un forillo serigrafiado y el necesario escenario central que acomodaba a los tres políticos y el moderador encargado de conducir el debate, el periodista de la TVG Alfonso Hermida. El diseño escenográfico fue encargado a la misma empresa responsable del cambio de decorado de informativos en 2007. Con ello se quería conseguir una coherencia estética que reforzase la imagen de renovación de los espacios informativos de la emisora. Las señas de la propuesta eran la sobriedad 
y los colores claros, con líneas curvas y limpias que buscaban transmitir fluidez, transparencia y modernidad.

El forillo incluía una escenografía serigrafiada en continuidad con el logo del debate que permitía asegurar el mismo fondo para los tres candidatos, un requisito pactado con los interlocutores de los tres partidos. Las intervenciones estéticas como los grafismos empleados se guiaron por un criterio común que priorizaba la funcionalidad y buscaba reforzar la presencia de los candidatos, sin distraer excesivamente la atención.

Estos delicados equilibrios estéticos fueron el resultado del trabajo previo entre los jefes de equipo en la etapa de preproducción. El único condicionante externo fue el relativo al frontal de la mesa. A menudo, los responsables de imagen prefieren ocultar la parte inferior del cuerpo cuando los candidatos han de estar sentados. Del mismo modo que un candidato a menudo no sabe qué hacer con las manos en pantalla, una postura poco favorecedora de las piernas puede arruinar la imagen televisiva del político de turno. La solución más efectiva para evitar estos planos indiscretos es ocultar la parte inferior del cuerpo y, para ello, se colocó en la mesa un panel frontal que sólo dejaba a la vista la parte superior del cuerpo de cada candidato.

\subsection{Despliegue espectacular}

La necesidad de garantizar una estética común para los planos de los intervinientes hizo que se decidiese contar con tres cámaras para cada candidato. A estas nueve cámaras hay que sumar la del moderador y otras cuatro más: grúa interior, travelling motorizado, steadicam y grúa exterior para recoger la llegada de los candidatos. En total, catorce cámaras. La contención formal se combinaba así con un despliegue extraordinario desde el punto de vista técnico para dotar a la emisión televisiva de la potencia visual que un evento histórico para la TVG requería.

En términos de producción, el programa se planificó como una retransmisión en exteriores. Se desplazó para ello una unidad móvil con control de realización. Además, se cuidó al máximo la iluminación, con 
un diseño neutro, pero exhaustivo, que cubría cuatro grandes zonas: el exterior del hotel, la sala de autoridades, el paseíllo hasta la mesa central y el claustro.

La iluminación de la fachada del hotel era un esfuerzo que tendría una rentabilidad muy limitada, ya que la mayoría de la emisión se desarrolló en el interior del claustro. Sin embargo, esta luz exterior ayudaba a reforzar la idea de un evento extraordinario, por lo que se consideró que este esfuerzo era necesario.

\subsection{Alfombra roja: la llegada de las estrellas (planteamiento)}

La retransmisión se promocionó como si fuese el estreno de una superproducción. Para crear la máxima expectación posible se implicó al resto de los medios y para ello la emisión del debate fue anunciada en rueda de prensa ante los colegas del resto de periódicos, emisoras y agencias de prensa, convocados para la ocasión. Se les entregó documentación específica, que incluía una carpeta con transparencias que permitían superponer el diseño de la escenografía sobre el claustro original.

La CRTVG ofreció acreditaciones a los medios que deseaban asistir en directo al debate. Para ello se diseñaron unas tarjetas específicas y se ubicó a los medios en una sala de prensa en la que se colocó una pantalla gigante. No obstante, en los segmentos de autopromoción del debate en la $T V G$, la emisora necesitaba fotografías de calidad para dar forma a la estética de la emisión y la línea gráfica del debate. Aun compartiendo muchas características, la imagen fotográfica y la imagen en movimiento divergen también en multitud de aspectos. Las fotos resultan a menudo insustituibles a la hora de dar forma a un segmento promocional de este tipo. Por ello, y a pesar de contar con un amplio banco de imágenes de los candidatos en sus archivos, la TVG hubo de recurrir a servicios de documentación externos y adquirió imágenes fotográficas de los candidatos, seleccionadas entre las ofrecidas por la agencia Efe y el periódico La Voz de Galicia.

Llegado el día, la fachada del hotel-monumento San francisco fue decorado con una serie de grandes lonas con el logo del debate que 
servían como elemento escenográfico para los planos de llegada de los candidatos, recogidos en plano corto por una cámara estabilizada o steadicam y una cámara en grúa para los planos generales. A continuación, la steadicam y otras 3 cámaras autónomas seguían a los candidatos en su paseíllo hasta el claustro. La importancia del evento que iba a comenzar quedaba subrayada por una iconografía singular y una iluminación original. Ambas dotaban de un marco espectacular al comienzo del debate televisivo.

\subsection{El duelo: a pie o a caballo}

Los múltiples y puntillosos detalles fueron negociados por la TVG con los correspondientes interlocutores en cada partido. Uno de los más delicados es la elección de las sillas de los candidatos. Después de examinar varias opciones, se alcanzó un acuerdo en torno a un modelo, cuyo pistón central hubo que soldar para fijarlo a la altura acordada y evitar que los candidatos modificasen dichas medidas y girasen cuerpo o cabeza y se colocasen en posiciones forzadas o poco favorables. Además, se eliminaron las ruedas que la silla traía de serie para evitar desplazamientos involuntarios y mantener las posiciones fijadas en la negociación.

En la escenografía, los elementos principales eran la mesa para los candidatos y el atril para el moderador. La mesa de los debatientes delimitaba claramente tres posiciones, tan próximas que hacían posible componer planos conjuntos como suficientemente separadas para facilitar la labor del realizador a la hora de aislar la imagen de cada uno de los candidatos. Mesa y atril estaban claramente separados, pero unidos por un puente liviano a ras de suelo, una solución que proporcionaba continuidad al conjunto y permitía separar al moderador del fragor dialéctico.

\subsection{The end (desenlace)}

La preparación del debate 27-F permitió afrontar con éxito una emisión televisiva excepcional. Candidatos y audiencia reconocieron el trabajo realizado. Desde las negociaciones previas hasta el resultado final, hubo unanimidad en el alto nivel técnico y estético alcanzado, 
homologable a las producciones de nuestro entorno audiovisual. Mecánica, estética y logística funcionaron de manera coordinada para hacer llegar a la audiencia los principales mensajes de los candidatos. En estos casos, el papel de la televisión es servir de conducto entre estos y sus posibles electores. Las habilidades comunicativas de los candidatos y el contenido de sus mensajes quedaron a la vista de una audiencia que ahora debía decidir si lo visto y oído iba a influir en el sentido de su voto.

\section{Conclusiones}

Dada la envergadura de la inversión y su repercusión en términos de posible impacto en los electores, la preproducción de un gran debate electoral debe ser afrontada con una antelación de varios meses. Corresponde al canal preparar la parte profesional y estética en la fase de preproducción con la previsión necesaria, aunque determinados extremos han de ser negociados casi hasta el último momento con los interlocutores de las fuerzas políticas. En este difícil equilibrio, el andamiaje estrictamente televisivo se ve auxiliado por las certezas que en términos de contenido y mecánica aporta el exoesqueleto informativo del marco legal.

El despliegue técnico que conlleva la emisión de un debate electoral entre los principales líderes políticos se ve reflejado en el correspondiente esfuerzo económico que ha de afrontar el canal televisivo que lo acoge. Si examinamos el gasto global en la cobertura de las elecciones generales de 2008, observamos que lo invertido en la producción del debate del $27-\mathrm{F}$ equivale a un $35 \%$ del presupuesto global destinado a la cobertura de los comicios. Así, la inversión necesaria para llevar a cabo un gran debate de estas características en una televisión pública puede ser cuantificada en torno a un tercio del presupuesto global destinado a la programación especial que se ocupa de los comicios. 


\section{Bibliografía}

Álvarez Rico, M. (1999). Legislación básica de Informática. Madrid: Tecnos. Arnaldo-Alcubilla, E. y Delgado-Iribarren, M. (2009). Código Electoral. Madrid: La Ley.

Blanco, R. (ed.) (2011). Galicia. Estatutos de Autonomia, 1936 y 1981. Santiago: Parlamento de Galicia.

Galindo, F. y Regueira, C. (2018). "Cobertura informativa de procesos electorales: innovación y oportunidad de un servicio público esencial". En VVAA La TV pública en Europa: innovación, retos y tendencias. CAC 146. La Laguna, Tenerife: Latina.

Lippman, W. (1965). Public Opinion. New York: Free Press.

Merino Merchán, J. (1996). Legislación electoral. Estatal, autonómica y de la Unión Europea. Madrid: Tecnos.

Roglán, M. y Equiza, P. (1996). Televisión y lenguaje. Barcelona: Ariel. 



\title{
¡Organización!: producción y realización de los debates electorales en España (1993-2016)
}

\author{
María Gallego-Reguera \\ Universitat de Lleida \\ Isabel Martínez-Martínez \\ Universidade de Vigo
}

\begin{abstract}
PARA CITAR: Gallego-Reguera, M. y Martínez, I. (2019). "¡Organización!: Producción y realización de los debates electorales en España (1993-2016)”. En Conde-Vázquez, E., Fontenla-Pedreira, J. y Rúas-Araújo, J. (Eds.), Debates electorales televisados: del antes al después (pp. 6783). Cuadernos Artesanos de Comunicación, cac 154. La Laguna (Tenerife): Latina. DOI: 10.4185/cac154
\end{abstract}

\section{Resumen}

El debate electoral, como producto audiovisual, no escapa a las exigencias de producción y realización de cualquier programa televisivo. Es más, por su relevancia mediática y su importancia política su realización técnica forma parte importante del proceso de negociación. Al final, las decisiones que se toman en referencia a la realización del programa de televisión tienen tanta importancia porque se trata de establecer la propia puesta en escena de los candidatos en directo ante la audiencia. Esto incluye no solo la disposición de los candidatos, sino también el número de cámaras, la localización y los recorridos de las mismas, el tipo de planos y planos escucha, la iluminación, la música, etc. 
En este capítulo se analizará la negociación de los aspectos técnicos, que va a tener dos momentos clave. El primero, el diseño del propio formato que quedará reflejado en el documento de acuerdo. El segundo, que se producirá el propio día del debate cuando los asesores inspeccionan y comprueban la puesta en escena y la propia realización técnica en directo del programa televisivo. El principal objetivo de esta investigación es realizar una comparativa entre las condiciones técnicas de los debates, que se realizaron en España con motivo de las elecciones generales en 1993, 2008, 2011 y 2015, y el debate a cuatro que se efectuó ante los comicios generales de 2016.

Palabras clave: debate, televisión, política, realización, formato, cara a cara, España.

\section{Breve historia de los debates electorales entre candidatos a la presidencia del Gobierno en España}

T A historia de los debates electorales en España entre candidatos a Lla presidencia del Gobierno se inicia en 1993, con los dos programas 'cara a cara' entre Felipe González (PSOE) y José María Aznar (PP).

Después de 15 años sin debates electorales de primer nivel, se retomaron ante las elecciones de 2008, cuando se enfrentaron en dos ocasiones José Luis Rodríguez Zapatero (PSOE) y Mariano Rajoy (PP). En las siguientes elecciones de 2011, se celebró un solo cara a cara entre Alfredo Pérez Rubalcaba (PSOE) y Mariano Rajoy (PP). Ante el nuevo contexto político marcado por el hundimiento del bipartidismo Boix y López-García (2014) y el auge nuevos líderes y estrategias de comunicación política Casero-Ripollés, Feenstra y Tormey (2016), López-García (2016), Sánchez Duarte (2016), Del Olmo, Ruiz y Díaz (2016), Rodríguez Andrés (2016) ante las elecciones de 2015 se desarrollaron diversos debates entre PP, PSOE, Podemos y Ciudadanos, organizados por El País y por Atresmedia, que no se analizan en este trabajo por no contar con la presencia del por entonces candidato a la presidencia por el PP, Mariano Rajoy. En este sentido es preciso señalar que, en debate de El País, el PP dejó el atril vacío, y en 
el organizado por Atresmedia, envió a la vicepresidenta del Gobierno, Soraya Sáenz de Santamaría.

El PP no quería que su líder se enfrentara con los nuevos partidos emergentes, Podemos y Ciudadanos, en ese momento. Sin embargo, Mariano Rajoy sí acudió a un debate cara a cara con Pedro Sánchez (PSOE) ante las elecciones de 2015. Ante la imposibilidad de formar Gobierno, se convocaron nuevas elecciones generales, que se celebraron el 26 de junio de 2016. En esta campaña electoral Mariano Rajoy (PP) accedió a un debate a cuatro entre PP, PSOE, Ciudadanos y Unidos Podemos.

\begin{tabular}{|c|c|c|c|c|}
\hline Fecha & Candidatos & $\begin{array}{c}\text { Entidad } \\
\text { organizadora }\end{array}$ & $\begin{array}{c}\text { Modera } \\
\text { ción }\end{array}$ & $\begin{array}{c}\text { Realiza } \\
\text { ción }\end{array}$ \\
\hline $24 / 05 / 1993$ & $\begin{array}{l}\text { Felipe González (PSOE) } \\
\text { José María Aznar (PP) }\end{array}$ & Antena 3 TV & $\begin{array}{l}\text { Manuel } \\
\text { Campo } \\
\text { Vidal }\end{array}$ & $\begin{array}{l}\text { Cara a Cara } \\
\text { Mesa con } \\
\text { moderador. } \\
\text { Plató sin } \\
\text { público }\end{array}$ \\
\hline $31 / 05 / 1993$ & $\begin{array}{l}\text { Felipe González (PSOE) } \\
\text { José María Aznar (PP) }\end{array}$ & Telecinco & $\begin{array}{l}\text { Luis } \\
\text { Mariñas }\end{array}$ & $\begin{array}{l}\text { Cara a Cara } \\
\text { Mesa con } \\
\text { moderador. } \\
\text { Plató sin } \\
\text { público }\end{array}$ \\
\hline 2008 & $\begin{array}{l}\text { José Luis Rodríguez } \\
\text { Zapatero (PSOE) y } \\
\text { Mariano Rajoy (PP) }\end{array}$ & $\begin{array}{l}\text { "Cara a Cara" } \\
\text { Academiatv }\end{array}$ & $\begin{array}{l}\text { Manuel } \\
\text { Campo } \\
\text { Vidal }\end{array}$ & $\begin{array}{l}\text { Cara a Cara } \\
\text { Mesa con } \\
\text { moderador } \\
\text { Plató sin } \\
\text { público }\end{array}$ \\
\hline 2008 & $\begin{array}{l}\text { José Luis Rodríguez } \\
\text { Zapatero (PSOE) y } \\
\text { Mariano Rajoy (PP) }\end{array}$ & $\begin{array}{l}\text { Academiatv } \\
\text { "Cara a Cara" }\end{array}$ & Olga Viza & $\begin{array}{l}\text { Cara a cara } \\
\text { Mesa con } \\
\text { moderador. } \\
\text { Plató sin } \\
\text { público }\end{array}$ \\
\hline 2011 & $\begin{array}{l}\text { Rubalcaba (PSOE) y } \\
\text { Mariano Rajoy (PP) }\end{array}$ & Academiatv & $\begin{array}{l}\text { Manuel } \\
\text { Campo } \\
\text { Vidal }\end{array}$ & $\begin{array}{l}\text { Cara a Cara } \\
\text { Mesa con } \\
\text { moderador. } \\
\text { Plató sin } \\
\text { público }\end{array}$ \\
\hline $14 / 12 / 2015$ & $\begin{array}{l}\text { Mariano Rajoy (PP) } \\
\text { Pedro Sánchez (PSOE) }\end{array}$ & Academiatv & $\begin{array}{l}\text { Manuel } \\
\text { Campo } \\
\text { Vidal }\end{array}$ & $\begin{array}{l}\text { Cara a Cara } \\
\text { Mesa con } \\
\text { moderador. } \\
\text { Plató sin } \\
\text { público }\end{array}$ \\
\hline $13 / 06 / 2016$ & $\begin{array}{l}\text { Mariano Rajoy (PP) } \\
\text { Pedro Sánchez (PSOE) } \\
\text { Albert Rivera } \\
\text { (Ciudadanos) } \\
\text { Pablo Iglesias (Unidos } \\
\text { Podemos) }\end{array}$ & Academiatv & $\begin{array}{l}\text { Ana Blanco } \\
\text { Pedro } \\
\text { Piqueras } \\
\text { Vicente } \\
\text { Vallés }\end{array}$ & $\begin{array}{l}\text { Debate a } 4 \\
\text { Atril } \\
\text { Plató sin } \\
\text { público }\end{array}$ \\
\hline
\end{tabular}




\section{Análisis y comparación del formato y la realización técnica de los debates electorales en España (1993-2016)}

El formato y la realización técnica de los mismos ha sido un campo de estudio analizado en diversas investigaciones sobre comunicación política. Algunos investigadores consideran que el formato es tan importante que puede influir en el comportamiento y la argumentación de los candidatos. Es el caso de Kraus (1988: 121), quien asegura que puede dificultar el desarrollo de un hilo argumentativo sólido. Sobre la influencia del formato han profundizado también Carlin, Howard, Stanfield y Reynolds (1991). Aun así, McKinney y Carlin (2004: 208) advierten que son necesarias investigaciones adicionales en el área.

En este sentido, es preciso tener en cuenta que existen tres formatos clásicos de debate: con moderador, con panel de prensa y por alcaldías (Schroeder, 2012). Los partidos políticos negocian el formato que mejor conviene a sus candidatos, por ello, este aspecto forma parte del proceso de negociación.

En concreto los debates en España han sido analizados desde el punto de vista práctico y teórico por varios autores, entre los que se encuentran Campo Vidal (2013), Canel (2006), Castells (2009), Díez Nicolás y Semetko (1995), Gallego Reguera (2009, 2012, 2016), Marín (2003), Ruiz Contreras (2007), Santamaría (2012) y Vidal Riera (1997), así como los estudios comparativos internacionales que han realizado Schroeder (2012), con los debates de EE.UU., y Micovic (2012, 2014), con los debates de Serbia.

\section{La entidad organizadora}

Los debates entre candidatos a la Presidencia en España iniciaron su andadura en las recién estrenadas televisiones privadas en 1993, en Antena 3 TV y en Telecinco. Pero ante las elecciones de 2008, fue una asociación profesional, la Academia de las Ciencias y las Artes de Televisión, la que recuperó los debates de primer nivel en España.

La Academia de Televisión, fundada en 1997, es una es una institución sin ánimo de lucro que aglutina a los profesionales del sector 
audiovisual. Ante las elecciones generales de 2008, la institución se presenta por primera vez en su historia ante los partidos como una posible emisora del cara a cara y lo hizo bajo la presidencia de periodista Manuel Campo Vidal, quien contaba con una importante experiencia en la negociación y moderación de debates políticos (había negociado y moderado el primer debate en Antena 3 TV en 1993). Ante el desacuerdo entre los partidos por la cadena emisora del debate, la Academia de Televisión se ofreció a emitir una señal única e institucional que pudieran transmitir todos aquellos medios de comunicación que así lo solicitaran. Este modelo de organización se asemeja a la no-partidista Commission on Presidential Debates de los Estados Unidos, que también es una asociación sin ánimo de lucro que ofrece desde 1988 el debate a todas las cadenas que lo desean retransmitir. Para los partidos políticos esta fue una solución de consenso ya que tenían una clara intención de celebrarlos. Esta institución volvió a organizar los debates ante las elecciones generales de 2011, 2015 y 2016 en España.

\section{E1 formato y la realización técnica}

Según la definición del codirector y realizador de los debates de 2008, 2011, 2015 y 2016, Fernando Navarrete (2012: 117), "la realización es ni más ni menos que la 'puesta' en imágenes y sonidos de un acontecimiento o de una idea con la mayor fidelidad posible y de la forma más comprensible para el espectador". Por ende, el realizador es el encargado de construir el mensaje visual que recibe la audiencia televisiva. La realización de un debate electoral debe ser neutral y compensada; por eso, el realizador tiene una gran responsabilidad, ya que a través de las imágenes que emite puede distorsionar el mensaje que reciben los espectadores.

El realizador, por medio de la cadencia o sentido de los planos, puede actuar decisivamente para que uno de los candidatos salga beneficiado o lo que es más fácil aún, salga perjudicado al final del acto. Es decir, el realizador puede intervenir en el resultado de las elecciones generales. Por tanto, tienes que eliminar tu subjetividad. Y no es que en otros debates no haya que ser subjetivo, sino que aquí, en este caso, hay que llevar esto al último (Navarrete, 2012: 118). 
Está claro que el formato español de debate ha estado profundamente marcado por las negociaciones que se llevaron a cabo en esos primeros debates de 1993. En esta ocasión se estableció que la duración de los debates fuera de 90 minutos, la emisión se iniciaría a las 22:00 horas o a las 22:30 horas y el debate solo tendrá un corte publicitario de cinco minutos. En el acuerdo firmado por los partidos políticos se acordó que "se sugerirán conjuntamente a los moderadores de los debates bloques de temas para los mismos"; que no existirá público y que el debate se realizará en una mesa; que los debates se emitirán íntegros y que no existirán "documentales previos, resúmenes ni reportajes intercalados"; que las cadenas informarán sobre todos los detalles técnicos a los partidos políticos; que la situación de los candidatos respecto al moderador se alternarán en ambos debates y que "los moderadores velarán por las condiciones de igualdad en relación al número y tiempo de las intervenciones de los candidatos”.

Ambos programas constaban de dos partes de 45 minutos, cada una de ellas con un solo corte de publicidad de 5 minutos. Los tiempos reales se sobrepasaron bastante: el de Antena 3 duró 136 minutos (una hora más de lo establecido en principio) y el de Telecinco 167 minutos (una hora más y 17 minutos más de lo establecido en los pactos, y una hora y 5 minutos más de las previsiones realizadas por Telecinco). La mecánica del programa establecía intervenciones de 3 minutos con una réplica de 2 minutos y 30 segundos para el otro, después comenzaba la intervención inicial y final de cada una de las dos partes de que constaba (González cerró el debate de Antena 3 por imperativo del PSOE y el PP tuvo que ceder; en el de Telecinco un sorteo determinó el orden pocas horas antes de su celebración porque no se ponían de acuerdo). En caso de que hubiera más réplicas de las previstas tenía que cerrar siempre el candidato que estaba pactado que finalizara esa parte (Marín, 2003: 234).

Respecto a los cortes publicitarios establecidos para el debate, fue Valerio Lazarov, en 1993, quien solicitó que en esa hora y media de programa se incluyeran tres o cuatro cortes publicitarios. Los partidos se mostraron reticentes a aceptar la propuesta, pero finalmente accedieron a la propuesta intermedia de Campo Vidal (2013: 80), quien 
propuso un corte publicitario a mitad del debate y que admitieran la retransmisión de las llegadas y salidas de los candidatos, aunque fuera sin audio, así se podrían insertar otros dos cortes publicitarios al principio y al final del debate, siendo el mismo programa. Así nació una fórmula televisiva que hacía sus concesiones cinematográficas con la retrasmisión de estos momentos previos y posteriores al debate que también aportan mucha información. Este elemento que presenta un toque "teatral" y "cinematográfico" según Schroeder (2009: 80) y "que los debates americanos deberían considerar copiar". Este elemento se incorporó también en los debates del 2008, como se verá en este trabajo.

Finalmente, la emisión se dividió en tres partes, un programa previo con la llegada de los candidatos, el propio debate y la salida de los candidatos. Se optó por un debate en el que los candidatos estarían sentados en diferentes mesas y sin público. Para Marín (2003: 233), quien redactó una tesis doctoral sobre los debates electorales de 1993, se puede deducir que "es un formato ecléctico que se sitúa entre el modelo americano, francés y alemán”. Así el modelo español toma la espectacularización del debate del modelo americano, aunque difiere del mismo en la posición de los candidatos, ya que en América utilizan tanto el atril como la mesa, y en el panel de periodistas que realizan preguntas, aunque este formato tiene el peligro de derivar en una rueda de prensa conjunta más que en un debate.

El modelo español, establecido en 1993, evoca al francés justamente en la mecánica del cara a cara con la figura del moderador que controla las reglas del juego. En este cara a cara de 1993 también se decidió un debate sin público como se hacía en el modelo francés y en el alemán, para facilitar la concentración de los candidatos en el enfrentamiento dialéctico: "Por mutuo acuerdo de los partidos, en el plató de los debates de Antena 3 y Telecinco solo estaban los candidatos, el moderador, los operadores de cámara, los técnicos de la cadena y las azafatas" (Marín, 2003: 233).

Cuando se estableció la negociación para los debates de 2008 tuvo mucho peso el formato establecido en 1993. La Academia de Televisión emitió una señal neutra de los debates, que incluyó la llegada 
y la salida de los candidatos a los recintos de celebración. Los programas se celebraron el 25 de febrero y el 3 de marzo de 2008, en ambas ocasiones a partir de las 21:00 horas se inició la emisión de la señal institucional desde el recinto, donde se esperaba a los líderes. El programa de debate propiamente comenzaría a las 22:00 horas con la entrada de los candidatos y el moderador en el plató. Los debates se desarrollaron tal y como se había estipulado en las condiciones. La señal institucional emitió la llegada de cada candidato en su vehículo, por separado. Cada candidato fue recibido por el comité directivo de la organización de los debates y visitó el plató antes de cada programa. Los candidatos accedieron al plató acompañados por el moderador/a y posaron ante los medios gráficos saludándose. El primero en llegar al recinto fue Rajoy y Zapatero, el primero en salir, en ambas ocasiones.

En 2008 se decidió que los dos candidatos debatieran ante un moderador, dispuestos en una mesa, lo que parece ser una clara herencia del formato de los cara a cara de 1993, pero también una inspiración de los debates franceses de 2007 entre Nicolás Sarkozy y Ségolène Royal; prueba de ello es la similitud de su escenografía. Los partidos acordaron debatir en cinco bloques temáticos y realizar un reparto de tiempo equitativo, pero también bastante rígido, con una dinámica de intervenciones de 2 minutos para cada candidato.

Igual que en 1993, el debate se celebró sin público, minimizando así los riesgos para los candidatos. Aunque no se permitió el acceso a nadie a las instalaciones del plató, la Academia de Televisión diseñó un plan de protocolo especial para que más 200 invitados en cada debate pudieran seguir los programas desde el mismo epicentro del evento, en salas anexas, tal y como habían dispuesto Antena 3 TV y Telecinco en los debates de 1993. Pero en esta ocasión, entre los invitados se encontraban los representantes de las televisiones y medios emisores de los debates, además otros de representantes del mundo empresarial, político y mediático.

A la hora de establecer las directrices de la realización, del decorado, de la iluminación, de la comunicación a los medios o de la propia sintonía de los debates, se acordó siempre el criterio de la neutralidad. La realización se ejecutó con un reparto de tiempos y planos 
equitativos, la iluminación fue neutra, imitando la luz natural, los decorados y la sintonía también lograron ese punto imparcial, que no recordara a ningún color ni a ninguna nota musical que se pudiera vincular a una determinada opción política. Para la emisión de 2008 se dispusieron 20 cámaras y tres tipos de planos: corto, medio y generales (once ubicadas dentro del plató y nueve en los recorridos y la periferia de las instalaciones).

La realización de los debates 2008 fue diseñada por Fernando Navarrete, vicepresidente de la Academia de Televisión y codirector del debate, y por Tacho de la Calle, vicepresidente de la Academia de Televisión y productor ejecutivo del debate, siguiendo los términos acordados en los pactos entre partidos. "Pero lo cierto es que la rigidez de las normas políticas que envuelven el debate ayudan al realizador porque ordenan y clarifican las intervenciones, aunque restan creatividad al realizador" (Navarrete, 2012: 119). Los partidos políticos supervisaron la realización de los programas a través de Jorge Rábago (PP) y Miguel Barroso (PSOE), ambos responsables de los equipos de telegenia en sus respectivas organizaciones (Sánchez, 2014: 79). Tanto Rábago como Barroso mantuvieron reuniones con el equipo técnico de la Academia de Televisión para poner en marcha el dispositivo de realización del programa de televisión; además, supervisaron los debates desde la unidad móvil para asegurarse de que se cumplían los pactos acordados y no se emitieran gestos o planos que puedan perjudicar a sus respectivos candidatos.

Es interesante señalar que en los acuerdos firmados entre los partidos políticos y la Academia de Televisión se acotó el plano escucha a una duración entre dos y cuatro segundos cada treinta segundos y de forma compensada por candidato e intervención. Se especifica que "en los planos escucha seleccionados se mostrará al no interviniente solo en actitud de escuchar al oponente o tomando notas". No habrá planos escucha en las intervenciones iniciales y finales y estas se harán en plano corto. Se establece también los encuadres de cada candidato para los planos pactados mediante un plano de realización, y en la entrada y salida de los candidatos se deja libertad al realizador siempre que se eviten daños a la imagen del candidato. 
Figura 1: Disposición de las cámaras y tiros durante el debate entre Mariano Rajoy y José Luis Rodríguez Zapatero.

\section{PLANTA DE CAMARAS PLANOS Y EJES}

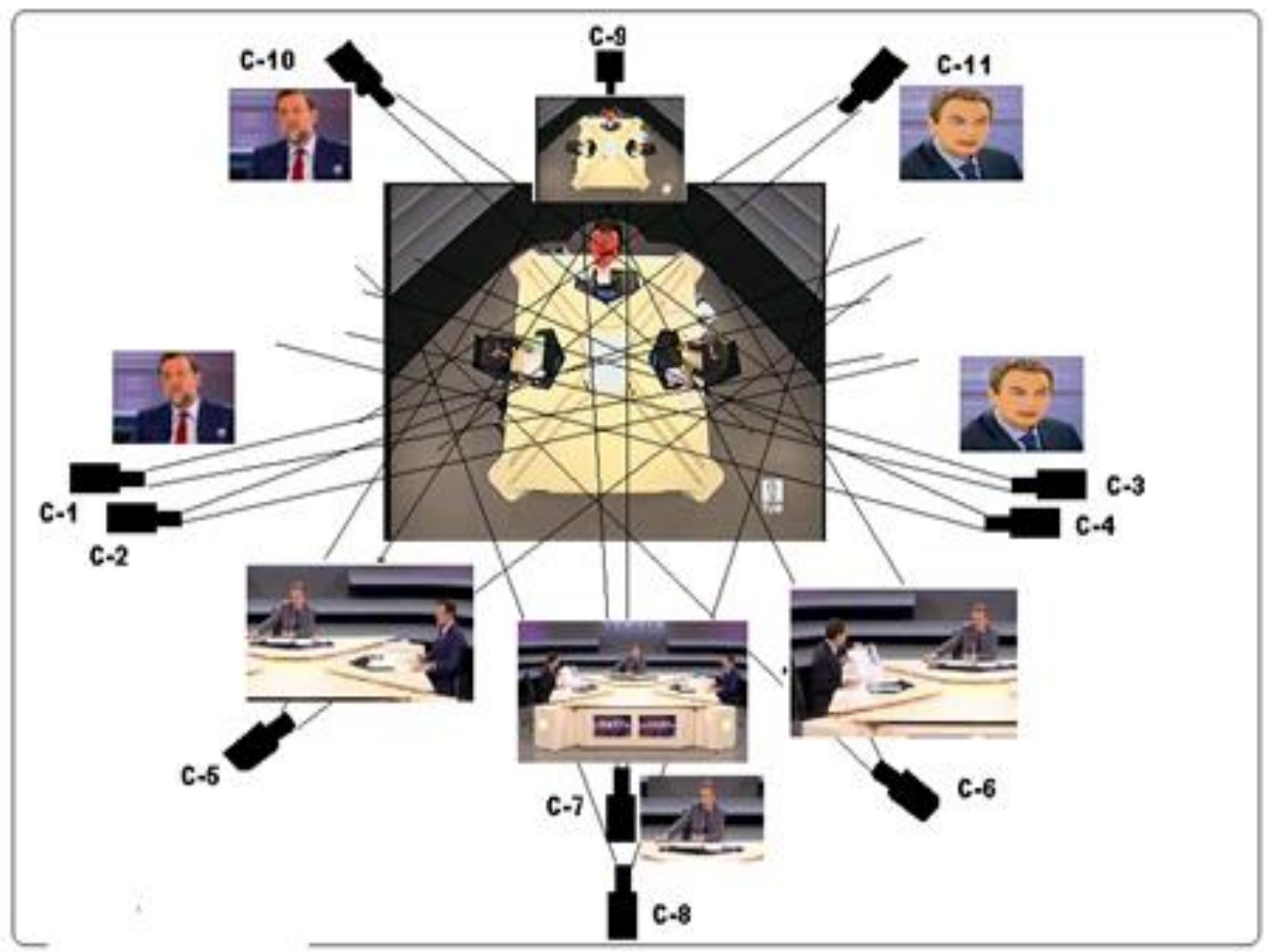

DISTRIBUCION CAMARAS CAMPOS YEJES

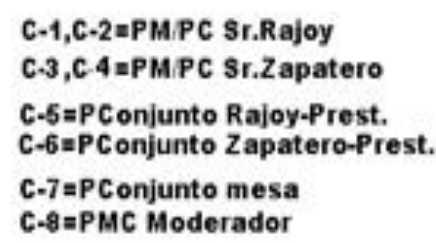

C-1,C-2 =PM.PC Sr.Rajoy C-3,C-4 =PM.PC Sr.Zapatero C-8=PMC Moderador
C-9 = Zenital para recursos
C-10 = Contraplano Seguridad Rajoy
C-11 $=$ Contraplano Sequridad Zapatero

Respecto a la moderación, también se estipularon unas normas. El documento de acuerdo define con detalle la función del moderador, que se va a limitar a presentar y a dar la palabra e introducir los bloques sin hacer comentarios ni valoraciones sobre las intervenciones de los candidatos. La principal función del moderador durante el debate será controlar los tiempos y compensar en caso de que algún candidato sobrepase su tiempo asignado. Lo hará primero con un gesto y pasados treinta segundos le rogará que finalice compensando al candidato adversario en la siguiente intervención y durante el mismo bloque 
siempre. También será responsabilidad del moderador impedir que un candidato interrumpa de forma continuada al otro dificultando su discurso. Si el candidato no consume el tiempo de su intervención no podrá recuperarlo en las siguientes intervenciones, pero si se excede se deberá compensar al otro candidato. En la última intervención no se admiten alusiones al candidato contrario, así que en caso de producirse el moderador permitirá la réplica al aludido y después dará la palabra a quien le toque cerrar.

En general, la realización de estos programas televisivos está marcada por la simetría, la proporcionalidad, el equilibrio y la sobriedad visual. Los partidos políticos dejaron a criterio de los moderadores la intervención dentro del programa de televisión, tanto para interrumpir a uno de los candidatos como para compensar los tiempos.

En las elecciones generales de 2011 se enfrentaron Alfredo Pérez Rubalcaba (PSOE) y Mariano Rajoy (PP). En esta ocasión decidieron que solo celebrarían un solo debate, no habría vuelta, como en las dos anteriores ocasiones, en 1993 y 2008. El formato acordado es muy similar a los anteriores. El debate se dividió en tres bloques temáticas, con 20 minutos para cada candidato en el primer bloque, 15 minutos por candidato para el segundo bloque y 10 minutos en el tercero. No se estableció una división por minutos de intervención como en el anterior, se buscó flexibilizar el formato en este sentido estableciendo cinco turnos de palabra para cada uno en el primer bloque, cuatro en el segundo y tres en el tercero. Así lo explica Valentín Carrera, miembro de la Comisión de Dirección:

La flexibilidad que se buscaba al dar libertad a cada candidato para repartir sus minutos se veía limitada por ese número fijo de turnos de palabra. Para que los candidatos mantuviesen bajo control sus intervenciones, lo más razonable era que dividieren los minutos por los turnos que tenían asignados en cada bloque. Así, dispondrían de 4 minutos en el primero, 3 minutos y 45 segundos en el segundo y 3 minutos y 20 segundos por intervención en el tercero. La libertad de palabra volvía a quedar sometida a la tiranía de los minutos. (Carrera, 2012: 123) 
Para la realización del programa se utilizaron 18 cámaras: once en el set central de mesa, de las cuales ocho grababan el máster del debate y las otras tres, de reserva para casos de emergencia; dos se destinaron a la grabación de la lengua de signos y las otras cinco se ubicaron en la periferia del plató para realizar el seguimiento de las llegadas y salidas de los candidatos al Palacio Municipal de Congresos de Madrid.

El plató del debate fue diseñado para la ocasión y estaba inspirado en la máxima neutralidad. Para conseguir un espacio no lineal se utilizaron troncos piramidales dispuestos en semicírculo. En el centro del escenario se ubicó la mesa, diseñada en forma de cuadrado dividido en cuatro piezas iguales de color crema, que pretendía contrastar con el gris del fondo. Delante de cada candidato se dispuso un espacio para albergar los monitores, que indicaban el tiempo y la señal de salida, con forma trapezoidal y aristas redondeadas. Para el moderador se instalaron tres monitores, dos con los tiempos de cada candidato y el tercero para la señal de salida. Respecto a la iluminación cabe señalar que se diseñaron dos tipos de iluminación diferentes, ya que los partidos políticos acordaron que los candidatos debatieran sentados el día anterior del debate.

Esto mismo ocurrió ante las elecciones de 2015. Los partidos políticos no se ponían de acuerdo en debatir sentados o de pie, así que la entidad organizadora, la Academia de las Ciencias y las Artes de Televisión, diseñó una mesa y también dos atriles, que nunca llegaron a utilizarse. Es necesario apuntar que este debate estuvo profundamente marcado por la austeridad. Tras un periodo de crisis, los partidos políticos querían apostar por un debate acorde con la situación del país, por eso la Academia de las Ciencias y las Artes decidió realizar el debate en las instalaciones donde se encuentra su propia sede, dentro de la Escuela de Cinematografía y del Audiovisual de la Comunidad de Madrid (ECAM).

En cuanto a la distribución del tiempo, el debate se compuso de cuatro bloques temáticos y cada uno de ellos comenzó con un minuto para responder a una pregunta. A continuación, se produjo un debate abierto. Se establecieron dos pausas publicitarias y la principal novedad, con respecto a los cara a cara anteriores, es que se introdujeron varias 
preguntas de directores de periódicos españoles para concluir los bloques temáticos.

Cabe recordar que la propia organización de este debate no estuvo exenta de polémica, ya que fue el único al que aceptó acudir Rajoy, declinando la participación en los organizados por el periódico El País y Atresmedia, en los que se pretendía un debate entre los cuatro candidatos a la presidencia del Gobierno. En el primero, el PP dejó el atril vacío y, en el segundo, acudió en representación del PP la vicepresidenta del Gobierno Soraya Sáenz de Santamaría.

Después de las elecciones de 2015 y de la imposibilidad de formar Gobierno, se volvieron a convocar elecciones en el año 2016. Esta vez sí se celebró el primer debate entre candidatos a la presidencia del Gobierno a cuatro, el 13 de junio de 2016, y fue organizado por la Academia de las Ciencias y las Artes de Televisión. Este programa, se distribuyó en cinco bloques temáticos y fue moderado fue moderado por periodistas de las principales cadenas emisoras: Ana Blanco (La 1 de TVE), Pedro Piqueras (Telecinco) y Vicente Vallés (Antena 3 Televisión). En cuanto a los tiempos, los moderadores podían gestionar el debate de acuerdo a criterios de equilibrio.

Con cuatro candidatos, la organización optó por atriles, decorados con el logotipo Deb4te, en un plató gris y negro. En el fondo se dibujaron unas líneas entrelazas con los colores corporativos de los cuatro partidos. Los candidatos realizaron una intervención de dos minutos para responder la primera pregunta y, a continuación, pidieron la palabra en caso de alusión. Para equilibrar las intervenciones se midió el uso del tiempo por parte de cada candidato.

\section{Conclusiones}

Los debates entre candidatos a la Presidencia del Gobierno en España han evolucionado hacia un formato más flexible, desde sus inicios en 1993 hasta las últimas elecciones analizadas en 2016. Es necesario precisar que a lo largo de su historia se han visto condicionados por el primer formato establecido, acordado entre PSOE y PP en 1993 y reflejado en los documentos de acuerdos con todo tipo de detalles. En 
cada debate se han producido innovaciones, sobre todo, en el uso del tiempo por parte de los candidatos, aspecto en el que se ha dejado más libertad a los moderadores para reconducir el debate y equilibrar tiempos, facilitando así el transcurrir del propio debate político. Por otra parte, observamos una variedad en el número de participantes, debido a la nueva realidad política y al fin del bipartidismo en España. Así el "cara a cara" de 1993, 2008, 2011 y 2015, ha dado paso al debate a cuatro de 2016.

De este trabajo se pueden extraer ciertas conclusiones que reafirman el punto de partida de esta investigación.

- Dado su impacto social y mediático, los partidos políticos analizan todas las variables posibles antes de tomar la decisión de acudir o no al debate, teniendo en cuenta fundamentalmente los datos relativos a la intención de voto, el riesgo de acudir al debate o las consecuencias de no acudir. En 2008 ante un empate técnico en los sondeos los partidos accederán al debate.

- Cuando se celebran debates televisados entre candidatos ante unos comicios generales, estos se convierten en el punto central de la campaña electoral, ya que atraen audiencias masivas. Aunque las investigaciones reflejan que los efectos en la intención de voto de estos programas televisivos son limitados, sin embargo, sí que influyen en el liderazgo de los candidatos y en la educación política de la ciudadanía.

- El proceso de negociación de los debates electorales es una parte fundamental de su desarrollo y condiciona el formato televisivo, que influye en cómo le llega el mensaje a los electores potenciales. Una vez acordado el debate, los partidos políticos intentan controlar al máximo la organización y producción del cara a cara estos eventos para minimizar los posibles riesgos que se derivan del enfrentamiento dialéctico con el opositor y de la puesta en escena de este combate. Este miedo de la clase política a los debates televisados dificulta el proceso de negociación, organización y producción del evento mediático. 
- La desconfianza de los partidos políticos en el adversario se plasma en la necesidad de ambos de dejar por escrito las condiciones técnicas de la realización del debate en documentos "cuasi-legales" como son los "documentos de acuerdo". En estos acuerdos documentos se perfila, entre otras muchas cuestiones, el formato televisivo.

- La realización de estos debates por parte de una institución como es la Academia de las Ciencias y las Artes de Televisión en España, por un lado, democratiza la emisión de la señal en abierto para todos aquellos medios (televisión, radio y medios digitales) $y$, por el otro, despierta reticencias entre los canales mayoritarios que solicitaban en paralelo a los partidos políticos la emisión en exclusiva propia.

- El debate es un evento político que provoca una gran expectación entre los medios de comunicación, tanto nacionales como internacionales, produciendo, en paralelo, un debate sobre el debate, lo que enriquece la información con la que cuenta el electorado para decidir su voto.

\section{Bibliografía}

Boix, A. y López García, G. (2014). "El significado de las Elecciones Europeas de 2014”. En España giro a la izquierda y bundimiento del bipartidismo. Madrid: Unión Europea Aranzadi.

Campo Vidal, M. (2013). La cara oculta de los debates electorales: Los debates cara a cara presidenciales en España. Madrid: Instituto de Comunicación Empresarial (ICE) y Nautebook.

Canel, M. J. (2006). Comunicación política: Una guía para su estudio y práctica. Madrid: Tecnos.

Carlin, D. P., Howard, C., Stanfield, S., y Reynolds, L. (1991). The effects of presidential debate formats on clash: A comparative analysis. Argumentation and Advocacy, 27, 126-136.

Carrera, V. (2012). "El formato y la estrategia en el Debate 2011". En Gallego Reguera, M. (coord.), El debate del Debate 2011: España. Madrid: Dykinson. 
Casero-Ripollés, A., Feenstra, R. y Keane, J. (2016). La reconfiguración de la democracia: el laboratorio político español. Granada: Editorial Comares.

Castells, M. (2009). Comunicación y poder. Madrid: Alianza.

Del Olmo, F. J. y Bustos Díaz, J. (2016). "Del tweet a la fotografía, la evolución de la comunicación política en Twitter hacia la imagen. El caso del debate del estado de la nación en España (2015)". Revista Latina de Comunicación Social, 71, 108-123.

Díez Nicolás, J. y Semetko, H. A. (1995). “La televisión y las elecciones de 1993”. Comunicación politica. Madrid: Universitas.

Gallego Reguera, M. (2009). El debate de los debates 2008: España y EE. UU. Barcelona: Àmbit.

Gallego Reguera, M. (2012). El debate del debate 2011: España. Madrid: Dykinson.

Kraus, S. (1962). The Great Debates. Bloomington: Indiana University Press.

López-García, G. (2016). "Todos, todo. Manual de periodismo, participación y tecnología". Dígitos: Revista de Comunicación Digital, 2016, 2, 159.

Marín, B. (2003). "Debates electorales por televisión”. En Berrocal Gonzalo, S., Dader García, J. L., y Rospir Zabala, J. Comunicación politica en televisión y nuevos medios. Barcelona: Ariel.

McKinney, M. S. y Carlin, D. B. (2004). Political Campaign Debates. En L. L. Kaid, Handbook of Political Communication Research (203234). New Yersey: Lawrence Erlbaum Associates.

Micovic, M. (2014). La comunicación y el discurso politicos en España y Serbia: Análisis comparativo de las estrategias argumentativas utilizadas en los debates electorales televisivos (Tesis Doctoral). Barcelona: Universitat de Barcelona.

Navarrete, F. (2012). "Claves para realizar un debate electoral". En Gallego Reguera, M. (coord.), El debate del debate 2011: España. Madrid: Dykinson.

Rodríguez Andrés, R. (2016). "El ascenso de los candidatos outsiders como consecuencia de las nuevas formas de Comunicación Política y la desafección ciudadana". Comunicación y hombre, 12.

Ruiz Contreras, M. (2007). La imagen de los partidos políticos: El comportamiento electoral en España durante las elecciones generales de 1993 y 1996. Madrid: Centro de Investigaciones Sociológicas (CIS). 
Sánchez, R. (2014). El control audiovisual de las campañas electorales. Madrid: Editorial Fragua.

Sánchez Duarte, J. M. (2016). "Ciberactivismo y cibervoluntarios: captación y organización de la militancia en red en los partidos políticos". En Manual de consultoría política. Madrid: Centro internacional de gobierno y marketing político.

Santamaría, J. (2012). Los candidatos tratan de afirmar su propia credibilidad. En Gallego Reguera, M. (coord.), El debate del debate 2011: España. Madrid: Dykinson.

Schroeder, A. (2012). Los formatos de los debates televisivos. En Gallego Reguera, M. (coord.), El debate del debate 2011: España. Madrid: Dykinson.

Vidal Riera, F. (1997). Los debates "cara a cara": Fundamentos básicos para la celebración de debates electorales audiovisuales entre los líderes de los partidos mayoritarios (Tesis Doctoral). Universidad Complutense de Madrid: Madrid.

\section{Reconocimiento de la investigación}

Este capítulo forma parte de los trabajos desarrollados en el marco del proyecto de I+D+I (Retos) "DEBATv, Debates Electorales Televisados en España: Modelos, Proceso, Diagnostico y Propuesta" (Ref. CSO2017-83159-R), financiado por el Ministerio de Economía, Industria y Competitividad (MINECO), la Agencia Estatal de Investigación (AEI) y el Fondo Europeo de Desarrollo Regional (FEDER) de la Unión Europea (UE). 



\title{
¿Qué ven mis ojos?: Análisis de la puesta en escena de los debates con Eye-Tracking
}

\author{
Ana Belén Fernández-Souto \\ Universidade de Vigo \\ Beatriz Legerén \\ Universidade de Vigo
}

\begin{abstract}
PARA CITAR: Fernández-Souto, A. y Legerén, B. (2019). “¿Qué ven mis ojos?: Análisis de la puesta en escena de los debates con Eye-Tracking”. En Conde-Vázquez, E., Fontenla-Pedreira, J. y Rúas-Araújo, J. (Eds.), Debates electorales televisados: del antes al después (pp. 85-107). Cuadernos Artesanos de Comunicación, cac 154. La Laguna (Tenerife): Latina. DOI: $10.4185 / \operatorname{cac} 154$
\end{abstract}

\section{Resumen}

Los debates electorales en televisión siguen contando con un gran peso dentro de la planificación estratégica de las campañas electorales. Existe bastante literatura sobre la propia organización de este tipo de eventos y su adaptación a las necesidades sociales con el paso del tiempo. Es evidente que las nuevas tecnologías afectan de forma directa a la propia organización del acto, así como a su desarrollo. Sin embargo, existen otros factores, que podemos denominar clásicos que, desde su inicio han preocupado de forma especial a los organizadores de los debates. Nos referimos a la propia puesta en escena del evento, donde se procura una cierta neutralidad en la que todos los participantes se sientan cómodos.

Esta intervención se centrará en el análisis de la puesta en escena de los debates electorales celebrados con respecto a las elecciones generales del año 1993, 2015 y 2016. Basándonos en el uso de técnicas propias 
de las neurociencias a través de eye-tracking, recopilaremos datos que nos permitirán verificar qué aspectos de la puesta en escena de los debates electorales son más importantes y valorados para los televidentes.

Palabras clave: debates, elecciones, escenario, escenografía, eyetracking.

\section{Introducción}

T OS debates electorales televisados entre candidatos provocan una 1 discusión democrática fundamental y constituyen un vehículo para informar y orientar políticamente a la ciudadanía. Las televisiones públicas tienen la obligación, como servicio público de interés general, de cumplir con su función social mediante la promoción del debate público, con la intención de fomentar la discusión democrática y la formación de la opinión pública.

Los debates electorales, como ocurre con cualquier otro evento, necesitan de una organización bien estructurada. En primer lugar, es necesaria una fase de investigación en la que se recaben los datos necesarios para poder dar formato al evento (información sobre audiencias, estudios de equilibrio de contenidos entre los distintos actores implicados en el evento, datos referentes a espacios, tiempos, objetivos, presupuestos, etc.), a partir de los cuales se empezará la fase de planificación.

En la fase de planificación, los organizadores aplican todos los conocimientos adquiridos en la etapa previa, de investigación, y dan formato al propio evento, atendiendo a detalles como el espacio (escenario, iluminación, sonido, decoración), el tiempo (tanto de planificación de los detalles, como montaje y desmontaje, etc.), la duración (del evento en su conjunto, de cada una de las fases organizativas, de los tiempos acordados para cada uno de los actores que intervendrán en el debate, etc.), y todo ello limitado al presupuesto establecido con anterioridad y de mutuo acuerdo entre las partes implicadas. 
Una vez planificado hasta el último detalle del debate, llega la fase de ejecución en la que se lleva a la práctica la anterior. Finalmente, está la fase de evaluación, que incluye el análisis del conjunto del evento y también su desglose en partes, incluyendo el juicio mediático y social que se produce sobre el propio debate una vez que esta finaliza: el debate sobre el debate (Rúas, 2011), tanto en los medios tradicionales como en los nuevos medios, que interpretan y reinterpretan su contenido.

Está claro que uno de los aspectos más complicados y menos reconocidos de los debates televisados es su organización, que incluye importantes desafíos: asegurar la participación de los candidatos, negociar los formatos, crear un calendario, hacer los arreglos logísticos, tratar con los medios de comunicación, organizar y transmitir los eventos en vivo (Campo Vidal, 2017: 9).

Partiendo del hecho de que la organización y planificación del debate es complicada y de que todo está negociado entre las partes implicadas antes de su ejecución (Gallego, 2009), parece interesante plantear una reflexión sobre el análisis del diseño y puesta en escena (plató, decorado, disposición de los candidatos y moderadores) de los debates.

Así pues, el principal objetivo que planteamos en esta investigación es el análisis los debates electorales celebrados con respecto a las elecciones generales del año 1993, 2015 y 2016. Para ello, centraremos el estudio en la parte de la comunicación no verbal que incluye los elementos estáticos del debate, siendo principalmente la escenografía.

Y realizaremos un experimento con eye-tracking sobre los debates al que fueron sometidos 13 pacientes y que se completó con un cuestionario realizado a los mismos.

\section{La importancia de la comunicación no verbal}

La comunicación es un proceso cotidiano y a la vez muy complejo. El hombre, por la condición de ser un individuo inmerso en una comunidad y en una sociedad tiene la necesidad de establecer 
relaciones a través de la comunicación utilizando diferentes métodos para ello.

Sea comunicación verbal o no verbal, la función más importante del lenguaje es la comunicación, es decir, el intercambio de informaciones.

Parece evidente la importancia y el peso que tiene el lenguaje verbal en el ámbito de la comunicación pública, sin embargo, no debemos desdeñar el entorno de la comunicación no verbal. Según algunos expertos, como Raymond Birdwhistell (2010) sólo el 35\% del mensaje humano pasa por la palabra, un 38\% está vehiculado por la entonación y el resto por la actitud corporal. El hombre es un ser multisensorial que algunas veces verbaliza y las palabras pueden ser lo que el hombre emplea cuando le falla todo lo demás. Por lo tanto, casi un $80 \%$ de la información transmitida en la comunicación es no verbal y surge de forma inconsciente.

Al hablar de comunicación no verbal podemos diferenciar entre:

a) la kinesia: estudia la parte de la comunicación relacionada con las posturas corporales, expresiones faciales, gestos, aspecto físico.

b) la paralingüística: se centra en el análisis de determinados aspectos no lingüísticos de la conducta verbal, como el tono, el ritmo, la velocidad de conversación, las pausas, etc.

c) la cronémica: analiza el peso que el tiempo tiene en cada una de las fases de la comunicación: qué se hace antes y qué se hace después, por ejemplo.

d) la proxémica: se ocupa de los problemas que surgen en torno a la utilización y estructura del espacio personal.

De todas estas variables que hemos mencionado y al objeto de nuestro estudio nos centraremos en la proxémica. 


\subsection{La proxémica}

De todos los elementos estudiados dentro de la comunicación no verbal y que podemos aplicar al análisis de los debates electorales, en este estudio nos centraremos en la proxémica. La palabra "proxémica" procede del latín y se entiende como el uso que se hace del espacio a la hora de comunicar.

El espacio siempre comunica, tanto al interactuar grupalmente como de forma individual, puesto que cada individuo define su posición dentro del grupo por el lugar que ocupa.

Dentro del análisis comunicativo del espacio, podemos analizar distintas variables:

- La postura del cuerpo en torno al espacio: cada persona tiene una forma característica de controlar su cuerpo cuando está sentado, de pie o caminando. Es algo tan personal como su firma y una clave fidedigna de su carácter. Con la postura está relacionado el ritmo corporal, aunque son movimientos muy sutiles y difíciles de distinguir salvo por los investigadores, para quienes se produce una danza cuando se conversa y cuando se escucha. Aun en un intervalo de silencio de la conversación, las personas se mueven simultáneamente porque reaccionan ante claves visuales en ausencia de otras verbales. Este aspecto centra la atención de los equipos preparatorios de los candidatos en el momento en que se diseña el espacio del plató donde se desarrollará el debate, puesto que la elección de si se hace de pie o sentado, la ubicación de cada candidato en el propio set de televisión, su posición respecto al moderador, la altura de las sillas o el atril, la altura de la cámara... todo ello puede utilizarse intencionadamente para generar una imagen u otra del candidato.

- El contacto corporal: existen culturas donde el contacto corporal es muy escaso, frente a otras donde es muy habitual. Este aspecto está muy relacionado con la proximidad física (Solé, 1998), muy presente en la relación con la intimidad y la 
dominación. La proximidad física varía según la situación, el entorno físico o el ambiente social; según los factores físicos del entorno (ruido, luz, temperatura), etc. Hablamos de 4 distancias diferentes:

1. Distancia intima, desde el auténtico contacto físico hasta los 45 centímetros. Distancia apropiada para reñir o conversaciones íntimas.

2. Distancia personal, desde los $45 \mathrm{~cm}$ hasta los 1’20 m. Es la distancia para los asuntos personales.

3. Distancia social, de los 1'20 $\mathrm{m}$ hasta los $4 \mathrm{~m}$ y es la apropiada para conversaciones formales.

4. Distancia pública, de los $4 \mathrm{~m}$ hasta el límite de lo visible o audible.

En el momento de analizar los espacios electorales televisados nos vemos en varias distancias de forma simultánea: por una parte, está la distancia social, en la que los candidatos se sitúan entre ellos y con respecto al moderador y la distancia pública, ya que en algunos de los debates existe público, pero, al tratarse de un evento televisado, el propio medio supone una distancia pública para con los espectadores.

- La orientación. Es el ángulo según el cual las personas se sitúan en el espacio, de pie o sentados, unas respecto a otras. Las dos orientaciones principales son "cara a cara" y "lado a lado". Cuando dos personas esperan competir, generalmente se sientan enfrentadas; si esperan cooperar, lo hacen una al lado de otra; mientras que para conversar normalmente lo hacen en ángulo recto. En general, en los debates se establece una orientación frontal (si son dos candidatos) de forma que se clarifica que entre ambos existe una gran diferencia ideológica y que ambos están en una "lucha" por posicionarse lo mejor posible en la mente de la audiencia; en esta orientación el moderador suele situarse entre ambos candidatos, en el medio, con la intención precisamente de mediar. Cuando existen varios candidatos, suele optarse por una disposición en media luna, donde el 
moderador también está en el medio o en un espacio diferente a ellos (bien sea de frente o en uno de los laterales).

- Disposiciones espaciales. Se trata de la distribución de los espacios en la interacción. Diferenciaremos entre:

1. Espacios de caracteres fijos. Es uno de los modos fundamentales de organizar las actividades de los individuos y los grupos, como los edificios, las calles, plazas o patios.

2. Espacios de caracteres semifijos, que hacen referencia básicamente a la relación entre el mobiliario y la conversación. Entre ellos existen a. Espacios sociófugos, aquellos que tienden a mantener separadas a las personas (salas de espera de las estaciones) y b. Espacios sociópetos, los que tienden a reunir a la gente (terrazas)

3. El espacio informal, que es un espacio no declarado donde entran en juego las relaciones interpersonales.

En el caso concreto de los debates electorales debemos remarcar que el espacio se mueve en torno a los caracteres semifijos, puesto que el plató de televisión se diseña específicamente para acoger un debate específico. Para cada ocasión se acude a un diseño concreto y diferente al anterior para dar cabida a los avances técnicos, a las necesidades del soporte (en este caso la televisión) y, sobre todo, a las necesidades de los candidatos, que aprueban su diseño y lo llegan a recoger en un documento que firman ante notario.

\section{El escenario como fuente de información y centro de planificación comunicativa en los espacios públicos}

Tal y como hemos adelantado, en este artículo pretendemos reflexionar y analizar los espacios televisivos donde se desarrollan los debates electorales, para lo que, en primer lugar, es necesario determinar qué consideramos como objeto de estudio.

Un estudio de televisión se define en función de la totalidad de elementos necesarios para desarrollar un programa televisivo hasta su emisión. Sin embargo, en este análisis no vamos a analizar los estudios 
de televisión, puesto que ello llevaría a analizar aspectos más técnicos como las cámaras, la sala de control, los monitores, la consola de producción, el control de realización, el área de grabación (cámaras, micrófonos). En nuestro caso particular, centraremos la investigación en el plató de televisión, que es aquel espacio físico donde se desarrolla el programa que llega hasta el espectador, es decir, es la composición final que aparece en el receptor final.

En este marco, cabe subrayar que el escenario le dice al público si los personajes están en un ambiente hostil, amistoso o neutral. Y toda esta información que se transmite se interpreta de una forma muy subjetiva en cada uno de los receptores.

Por ello, todas las personas implicadas en el planeamiento del espacio en el que se desarrollará el debate debe realizar propuestas en común, que recojan el espíritu y los condicionantes de cada una de las partes implicadas: la organización propiamente dicha (cadena de televisión y/o Academia de Televisión), los propios partidos políticos implicados y sus líderes y, por supuesto, el interés del público final.

\section{Análisis de las variables en el objeto de estudio}

Tal como venimos afirmando, aunque el debate no se circunscribe exclusivamente al plató donde se desarrolla (ya que se da importancia a detalles como forma en la que llegan los candidatos, su actitud, su vestimenta, con quién vienen acompañados). En este estudio centraremos el análisis en la variable del espacio y la comunicación que este implica.

En general vamos a encontrar tres formatos (Gallego, 2012): a) los candidatos detrás de un atril, 2) candidatos sentados en una mesa, y 3) debates por alcaldías, en los que el público rodea al candidato.

La decisión de realizar el debate de pie o sentados siempre ha sido un tema polémico ya que como la lógica y la historia demuestran, los candidatos más altos prefieren debatir de pie y los más bajos, prefieren hacerlo sentados. La presencia o no de público en los debates depende de la voluntad de los partidos políticos y también de las características 
del lugar de celebración del propio programa. Normalmente vamos a encontrar dos espacios típicos para la celebración del debate que son auditorio y estudios de televisión.

La puesta en escena es minuciosamente cuidada por los asesores políticos para que el contexto en el que se va a ejecutar el debate sea lo más favorable posible a su candidato. Desde el punto de vista del diseño de esta puesta en escena por parte de los organizadores, se contempla como principal objetivo el crear un espacio equilibrado para garantizar las máximas condiciones de igualdad de posibilidades. También se tiene en cuenta en el diseño del plató la sobriedad y relevancia que la ocasión merece.

En las siguientes secciones reflexionaremos sobre 4 debates televisados celebrados en España en las elecciones a nivel nacional (Academia TV, Año XI, número 140, pág. 13), concretamente los del año 1993, 2015 y 2016.

- 1993: Debate González-Aznar. Se celebraron dos debates uno en Antena3 TV y otro en Telecinco.

- 2015: Debate Rajoy-Sánchez, emitido por 12 cadenas.

- 2016: Debate Rajoy-Sánchez-Iglesias-Rivera, emitido por 17 cadenas.

La realización de este trabajo se ha llevado a cabo en varias fases.

\subsection{Selección de la muestra}

Para la selección de la muestra se ha tenido en cuenta los criterios de Goldberg, J. H., y Wichansky, A. M. (2003).

"The most frequently used techniques are various forms of usability testing, which have in common several key characteristics":

- Users are selected from target market groups or customer organizations.

- Users interact systematically with the product or service.

- They use the product under controlled conditions. 
- They perform a task to achieve a goal.

- There is an applied scenario.

- Quantitative behavioral data are collected.

Para la realización de este trabajo y estudio de carácter exploratorio se han seleccionado a 13 personas, entre 20 y 54 años, con estudios superiores, que firmaron una declaración de consentimiento informado, previamente a la realización del mismo.

\subsection{Procedimiento}

Hemos optado por una combinación de técnicas y métodos de estudio y observación, activa y pasiva en la búsqueda de una triangulación Campbell y Fiske (1959), Denzin (1970), con el objetivo de contrastar distintas perspectivas sobre un mismo objeto de estudio.

A tal objeto y una vez escogidos los debates con los que vamos a trabajar, se ha diseñado el experimento, procediendo de la siguiente forma.

Se creó una sucesión de imágenes que aparecerían de forma aleatoria, y donde los pacientes podían ver:

- fotos fijas de cada uno de los debates (plano general a la posición de cada uno de los participantes, presentador y candidatos), durante un máximo de 4 segundos.

- Clips de vídeo de 30 segundos de duración de cada uno de los debates (se han editado los vídeos para que la estructura de todos ellos sea igual, presentación del debate y presentación de cada uno de los candidatos).

Además del uso del Eye Tracking como herramienta de seguimiento ocular, que nos proporciona datos cualitativos, complementamos dicha técnica con un cuestionario complementario con el que se quiere averiguar, en base a las imágenes mostradas, cuál les había gustado más, si habían visto previamente los debates seleccionados, y cuáles eran los que le habían parecido en cuanto a su contenido. 
La primera cuestión, estaba relacionada con el recuerdo, ¿vio usted los debates cuando se emitieron por televisión?

Los tres restantes se plantearon en una escala de Likert, donde 1 - Estoy completamente en desacuerdo, 4 - Ni en desacuerdo ni de acuerdo, 7 Estoy totalmente de acuerdo

- ¿El debate ha tenido una puesta en escena atractiva?

- ¿El debate ha tratado temas relevantes?

- ¿El debate me ha resultado interesante?

\section{Los Debates}

\subsection{Debates de 1993}

En este primer debate de la democracia española se celebraron dos encuentros con los principales candidatos: Felipe González del PSOE y José María Aznar del $\mathrm{PP}^{25}$. El primero de ellos tuvo se celebró en las instalaciones de Antena3 TV en el mes de mayo, moderado por Campo Vidal y el segundo en Telecinco, con Luis Mariñas.

El primer aspecto a destacar de la organización de estos debates en lo que respecta al estudio espacial, se centra en la ubicación física donde se desarrolló, ya que ambos se celebraron en las instalaciones de las dos televisiones privadas del momento y no en la televisión pública ni en espacios externos al mundo audiovisual, tal y como se hizo más tarde con el alquiler de salas públicas. A este respecto, debe constar que el propio PP indicó que la televisión pública no cumplía las condiciones para un debate imparcial, aspecto este que utilizó como tema en el propio desarrollo del debate para atacar al PSOE. En cualquier caso, debe indicarse también que los debates se celebraron a propuesta de las propias cadenas organizadoras.

El hecho de decidir celebrar los encuentros en el ámbito empresarial privado y no en lo público indica una preocupación clara por los partidos de intentar buscar una mayor neutralidad.

${ }^{25}$ Véase el vídeo https://www.youtube.com/watch?v=ifng-gIzatQ

Programa emitido por "La Sexta", el día 17.02.2008. 
En el primer debate, todo estaba pactado y medido milimétricamente, desde la altura de la mesa, los saludos, las luces, el encuadre, los rótulos, los planos escucha y los tiempos, hasta, por supuesto, los temas y los tiempos.

En el último momento surgió un problema con el color del plató, cuyos colores recordaban al cromatismo de la campaña del Partido Popular. $\mathrm{Al}$ final se dieron unas pinceladas verdes y amarillas para evitar las suspicacias. La elección de los colores no es fácil para contentar a ambas partes, puesto que los colores corporativos de ambos partidos políticos están muy definidos: azul para el PP y rojo para el PSOE. Sin embargo, a la hora de pensar en decorados y fondos, suele optarse por colores que impliquen calma y neutralidad, por lo que los tonos azulados y grises suelen ser los predominantes.

Imagen 1. Plató de Antena 3 donde se celebró el debate de 1993

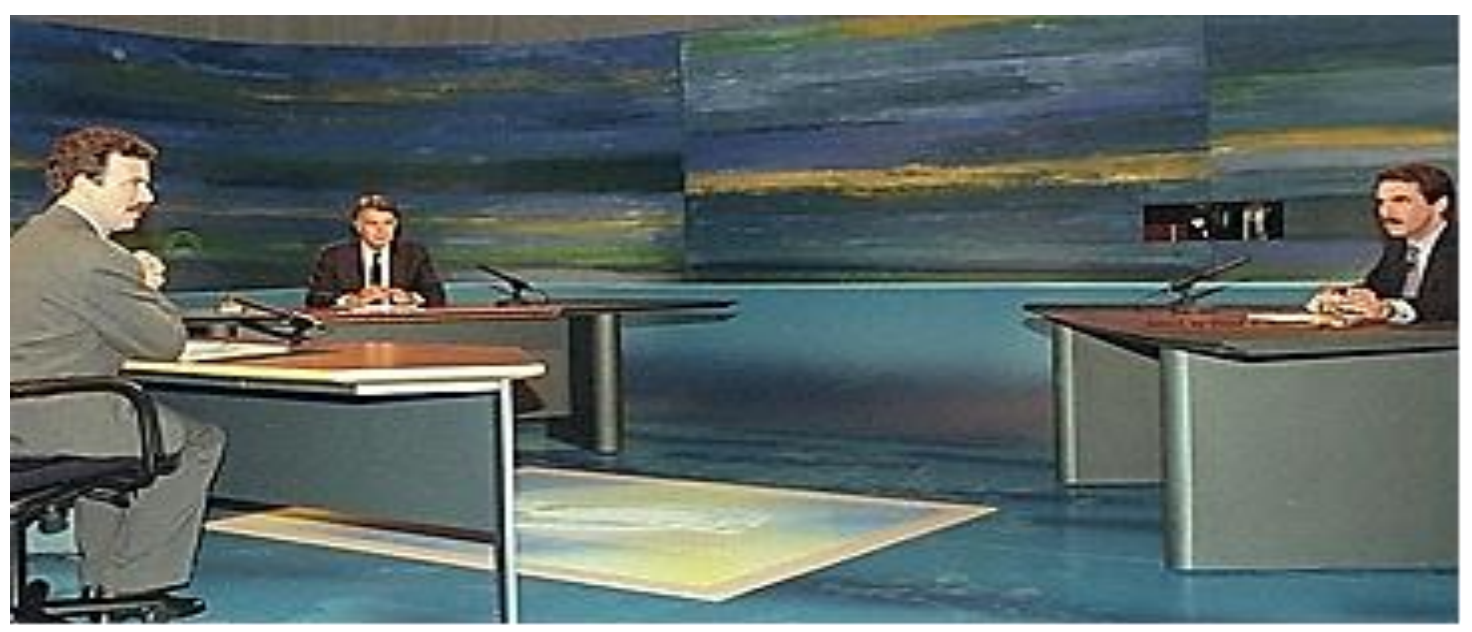

Fuente: $A b c, 16 / 12 / 2015$

En este primer debate el PP solicitó que se hiciese sentado, frente al PSOE que se centró en la altura de la mesa, que no quería una medida estándar, sino más alta de lo normal para que el candidato pudiese cruzar las piernas por debajo. La disposición de los candidatos no es baladí, ya que los equipos con candidatos altos intentan subrayar esa cualidad, frente a los de candidatos bajos que la intentan ocultar. Se trata simplemente de mostrar dominación en el caso de los altos a los bajos y de evitar la sumisión en el caso contrario. 
Se negoció que la distancia entre los candidatos debía ser de tres metros y se llegó a acuerdo en la disposición del mobiliario y la elección del mismo para el plató, tal y como se observa en la siguiente figura:
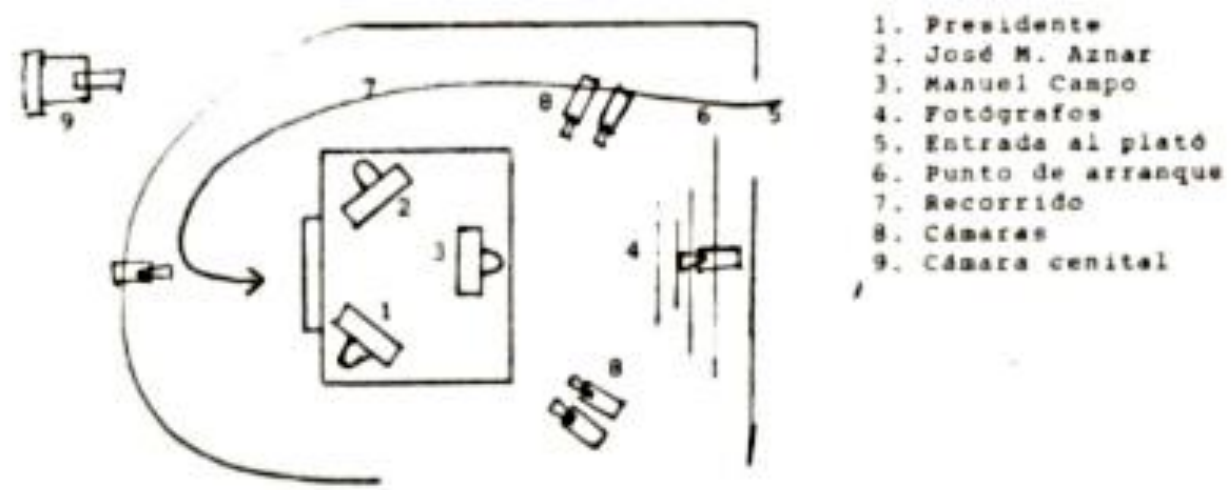

Fuente: Campo Vidal (2017: 231)

Antes de los debates, PSOE y PP llegaron a firmar un documento de condiciones aceptadas por ellos ante notario (Campo Vidal, 2017: 71). A este debate, una semana más tarde, siguió otro celebrado en Telecinco y moderado por Luis Mariñas. En esta ocasión el plató no supuso ningún problema. Se trataba de una estructura metálica en forma de equis que Valerio Lazarov había visto en el metro de Nueva York y después dibujó a los escenógrafos de Telecinco con muchas estructuras metálicas. En el plató había mesas separadas en triángulo abierto, con el fondo en colores azul, verde y amarillo, repitiéndose la gama del escenario del debate anterior, aunque con estructuras más metálicas y una importante presencia del logotipo de la cadena Telecinco que no se evidenció en el caso de Antena 3. 
Imagen 2. Plató Telecinco debate 1993

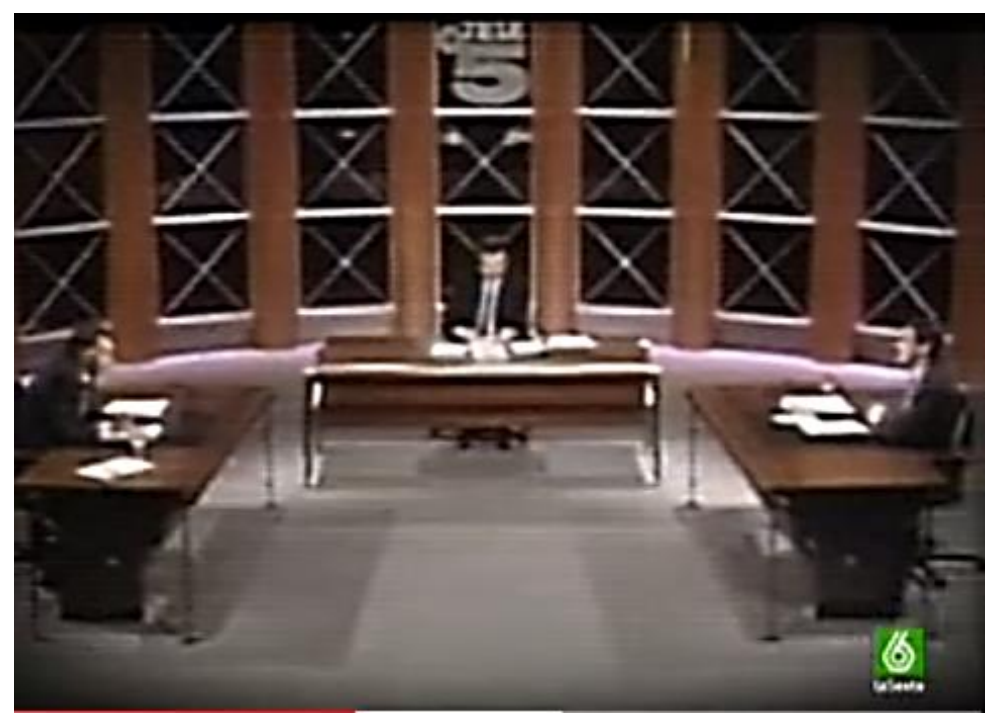

Fuente: La Sexta, 17/02/2008

En este segundo debate hubo menos tensión en la negociación llegando a haber detalles que se decidieron al azar, como la decisión de quién abría y cerraba el debate.

\subsection{Debate de 2015}

En 2015 se celebraron varios debates, pero para este estudio nos centraremos en el llevado a cabo entre Pedro Sánchez (PSOE) y Mariano Rajoy $(\mathrm{PP})^{26}$. El otro debate televisado fue "a cuatro" debido a la irrupción de dos nuevas fuerzas políticas: Podemos y Ciudadanos, pero no se tendrá en cuenta para este artículo ya que en él no acudió el líder del PP sino la segunda de a bordo, Soraya Sáez de Santamaría. Así pues, el entonces presidente del gobierno solamente debatió en televisión con el principal candidato de la oposición: Pedro Sánchez.

Al igual que ocurrió en el debate de 2011, el Debate fue organizado por la Academia de TV y moderado por Campo Vidal, esta vez en las instalaciones de la Escuela de Cinematografía y del Audiovisual de la Comunidad de Madrid (ECAM), interpretado como "campo de nadie" por ambos partidos implicados.

\footnotetext{
${ }^{26} \mathrm{http}: / /$ www.rtve.es/alacarta/videos/especiales-informativos/debate-caracara/3407700/
} 
En el debate de 2015 se primó la austeridad del plató, tras la crisis económica que estaba sufriendo el país. Cabe destacar que hasta última hora no se decidieron por mesa o por atriles, es más, se construyeron dos atriles que no se llegaron a utilizar.

Finalmente se optó por un crear un espacio neutral, con un plató decorado en todos grises y blancos donde la iluminación era fundamental. En el fondo se proyectaba el logotipo del programa como podemos ver en la Imagen 3.

El escenario era mucho más sobrio y planteaba una continuidad con los platós utilizados anteriormente: los dos candidatos se situaban frente a frente, en una mesa bastante similar a la del debate anterior, donde no se veían las piernas, se proyectaban imágenes y compartían -dentro de la distancia social- espacio con el moderador, que se situaba en medio de ambos. Una de las novedades es el tamaño de la mesa, que sólo cuenta con 1,70 metros de diferencia entre ambos candidatos, un cambio "intencionado" para que haya sensación de cercanía entre los dos líderes políticos, según el realizador del debate, Fernando Navarrete ${ }^{27}$.

Imagen 3. Escenario debate electoral 2015.

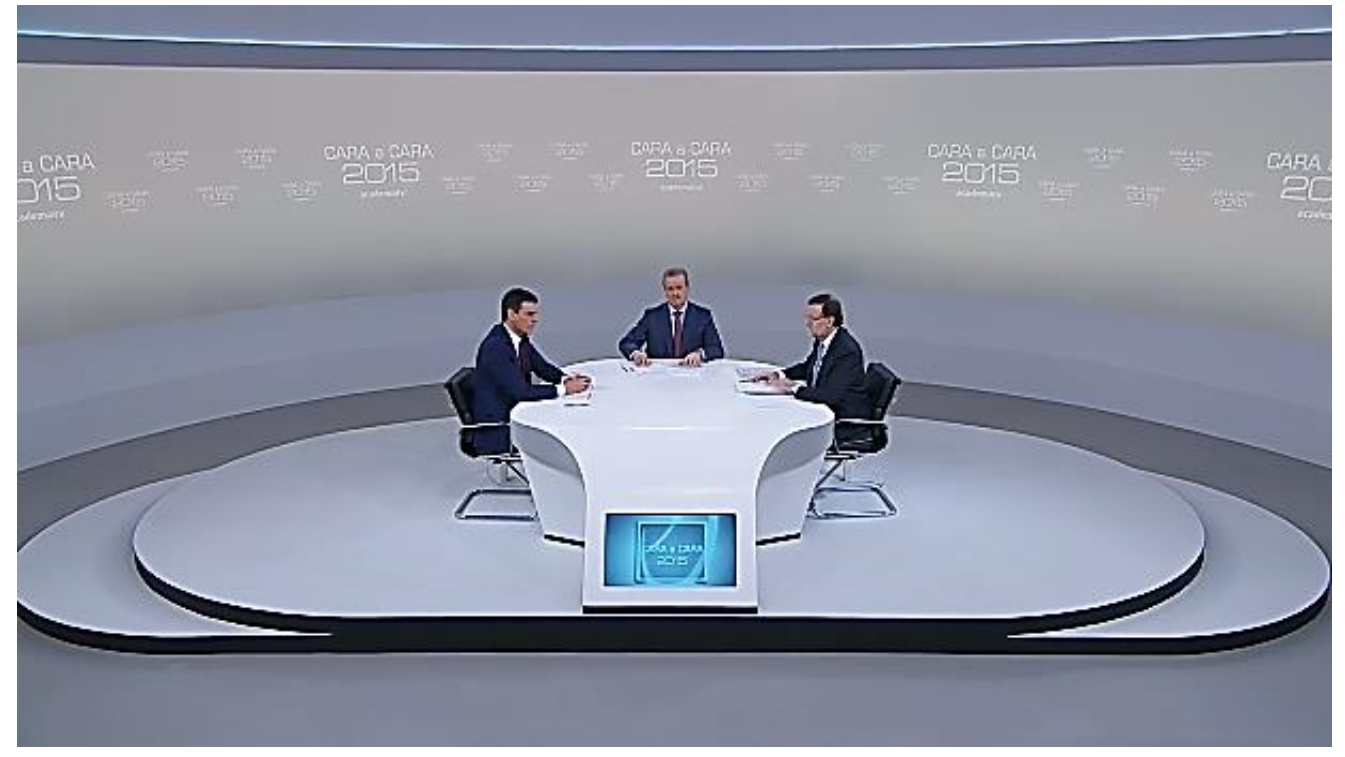

Fuente: Academia TV. Revista de la Academia no138 (2015)

\footnotetext{
${ }^{27}$ http:/ / www.rtve.es/noticias/20151214/ rajoy-sanchez-debaten-tvebusqueda-indecisos-ante-20d/1272980.shtml
} 
Una vez más, los partidos negociaron los aspectos señalados en los últimos debates.

\subsection{Debate de 2016}

A estas alturas de la historia política de España ya no se celebraron debates con los dos líderes, puesto que el bipartidismo ya había dejado de primar. Se emitió un único debate a cuatro ${ }^{28}$ : Rajoy, Sánchez, Iglesias y Rivera y como pionero, implicó muchos cambios con respecto a la organización de los debates anteriores.

Celebrado en el Palacio Municipal de Congresos y organizado por la Academia (con la colaboración de A3media, Mediaset y RTVE) se planteó un debate moderado por tres personas: Pedro Piqueras, Ana Blanco y Vicente Vallés.

Se construyó un plató específicamente para la ocasión y, por primera vez, no se hizo sentados al amparo de una mesa, sino de pie:

Imagen 4. Escenografía Debate 2016

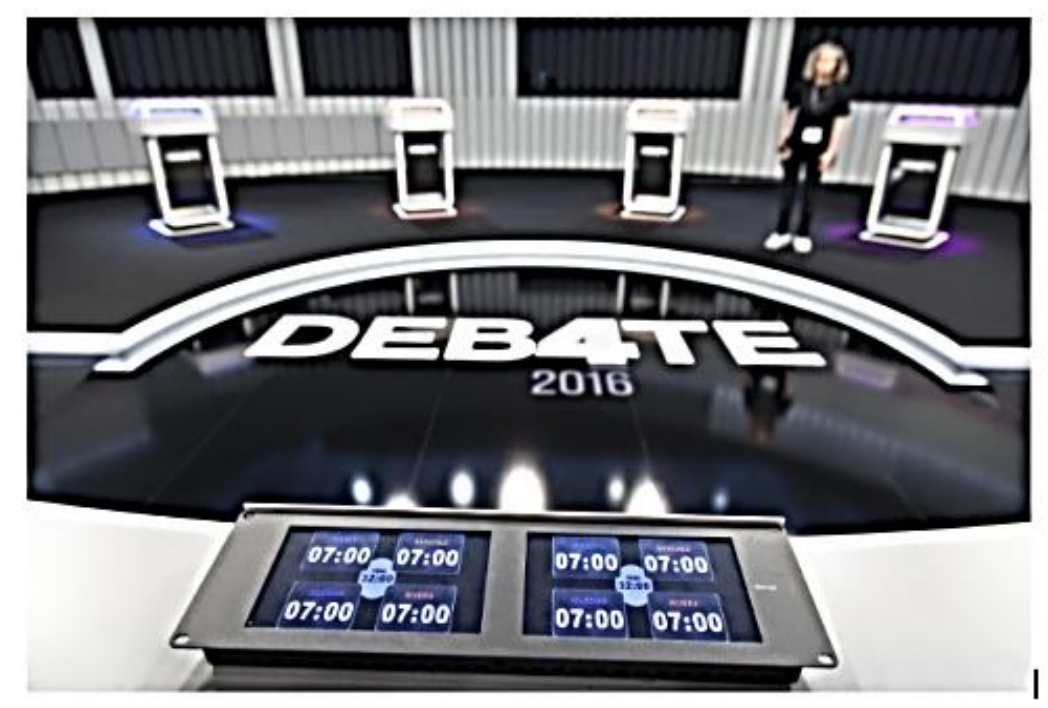

Fuente: Academia TV. Revista de la academia de las ciencias y las artes de televisión. $\mathrm{N}^{\circ}$ 140. (2016)

${ }^{28}$ http://cadenaser.com/ser/2016/06/14/videos/1465906149_096404.html 
Este hecho también viene justificado desde el punto de vista organizativo y es que, cuando hay más personas, resulta más cómodo el uso del atril, ya que una mesa para tantas personas sería demasiado grande.

Aquí hay que tener en cuenta que en el plató se dibujaron 4 líneas con los colores de cada partido (azul, rojo, morado y naranja) que se evidenciaban gracias a la iluminación y que permitía perfilar perfectamente a cada uno de los candidatos. Es evidente que los colores elegidos eran los corporativos de cada una de las fuerzas políticas. Una vez más y para que éstos destacasen sobre el resto, se optó por unos fondos con colores neutros de grises y blancos.

La distancia entre los candidatos también sigue enmarcada en la distancia social, aunque más recortada que en anteriores ocasiones, y el orden de los candidatos venía dado por su representación parlamentaria, tal y como se observa en la imagen 4. Esta justificación es la que también se dio para el orden de llegada de los candidatos al lugar donde se celebró el evento, frente al orden del minuto de oro final, que fue por sorteo ${ }^{29}$. Además, por primera vez se utilizaron tres moderadores que estaban situados frente a los candidatos en un espacio diferenciado.

Imagen 5. Debate 2016

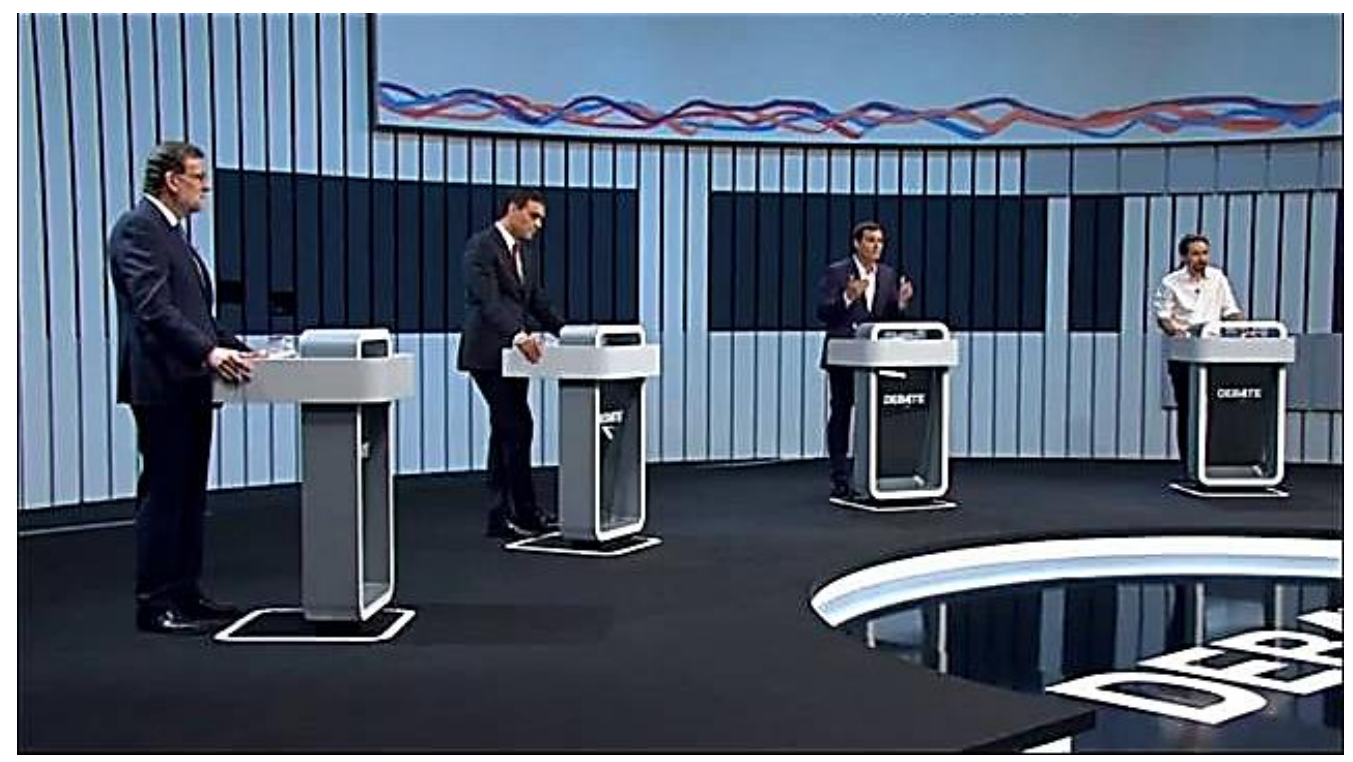

Fuente: Cadena Ser

\footnotetext{
${ }^{29} \mathrm{http}: / /$ www.rtve.es/noticias/20160613/directo-debate-cuatro-entre-rajoysanchez-iglesias-rivera/1358082.shtml
} 
Es de destacar en esta ocasión que, por primera vez, las redes sociales se convirtieron también en protagonistas del debate, antes, durante y después, constituyéndose como escenario virtual que los partidos y los candidatos también cuidaron meticulosamente.

\section{Resultados}

En cualquier debate electoral hay varias partes implicadas: por un lado, los organizadores del evento en sí, que han de ocuparse de la intendencia de la planificación y ejecución del evento y, por la otra, los propios políticos implicados y los partidos que les respaldan. Para que el debate salga adelante, es necesario crear una cadena de confianza entre todos estos actores para buscar un equilibrio y un protocolo que les ampare y permita el correcto desarrollo del encuentro.

Aun así, los intereses de unos y otros son bien diferenciados y es en la negociación previa a la emisión del debate televisado, cuando se plantean temas y se llegan a acuerdos que se plasman por escrito en forma de protocolos que rigen la ejecución del programa.

En este artículo hemos desarrollado una reflexión sobre el uso del espacio físico en los debates televisados en España desde 1993 hasta 2016 en el ámbito de las elecciones de carácter nacional en los que hayan participado los líderes de los principales partidos.

Desde los primeros debates de 1993 mucho ha evolucionado la escenografía de estos espacios televisivos. Es evidente que, en los primeros, no había tradición electoral que hiciese que los equipos asesores de los candidatos dedicasen muchos recursos y esfuerzos a la planificación del evento.

Los sujetos de la muestra se clasifican conforme al siguiente gráfico: 
Gráfico 1. Participantes en el experimento (edad y género)

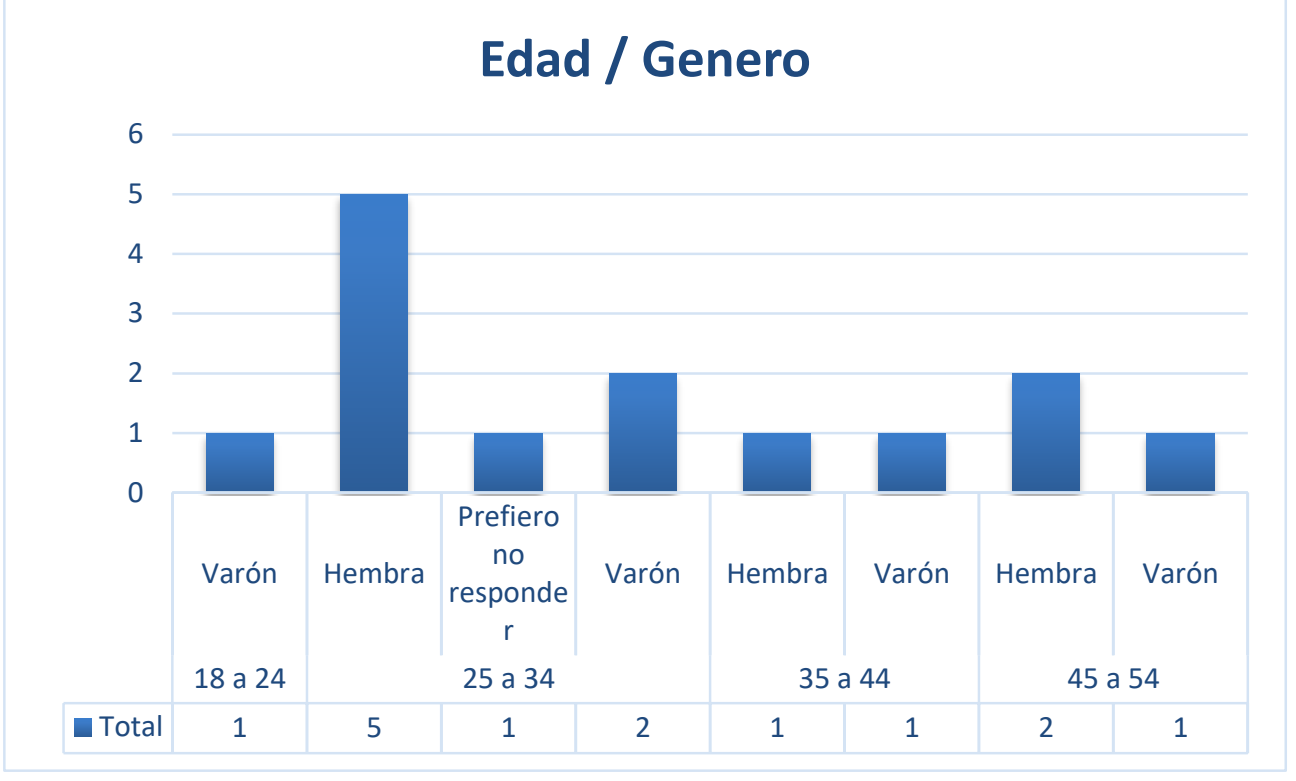

Fuente: elaboración propia

A su vez él experimento nos proporciona los siguientes datos:

- El tiempo medio de realización de la prueba ha sido de 10 minutos de duración para el visionado de las 3 imágenes de los debates (4 segundos cada una) y 3 videos (30 segundos cada uno).

- Fijación y recorrido de los ojos (Fixation map): Las mujeres en un primer momento se fijan en las personas y su posición, mientras que los hombres se fijan más en el entorno.

Imagen 6. Fixation map hombres 1993. Imagen 7. Fixation map mujeres 2015

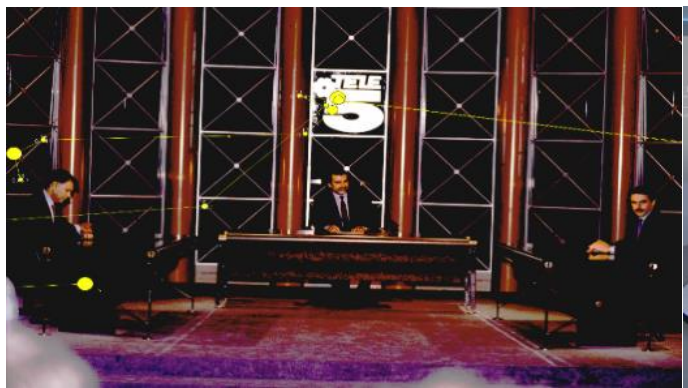

Fuente: elaboración propia

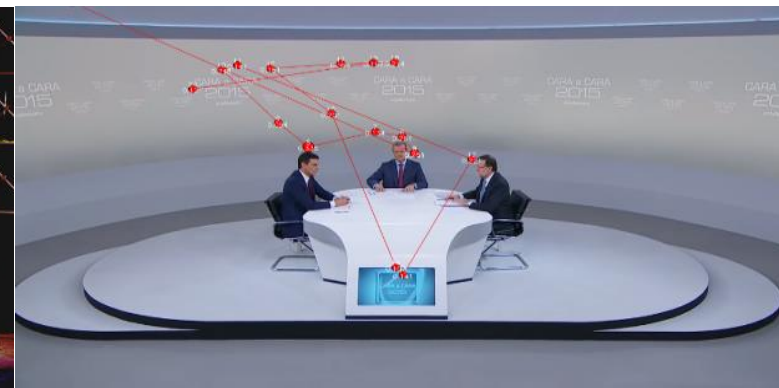

Fuente: elaboración propia

- Los patrones visuales de ambos géneros siguen la misma tendencia que en la lectura de sus lenguas maternas (en este caso gallego y castellano). De arriba a abajo y de izquierda a derecha. 
- Los mapas de calor, muestran la tendencia de los usuarios a dirigir su mirada a la izquierda de la imagen (en ambos casos han sido agregados los datos de ambos sexos.

Imagen 8. Mapa de calor 1993 Imagen 9. Mapa calor 2015

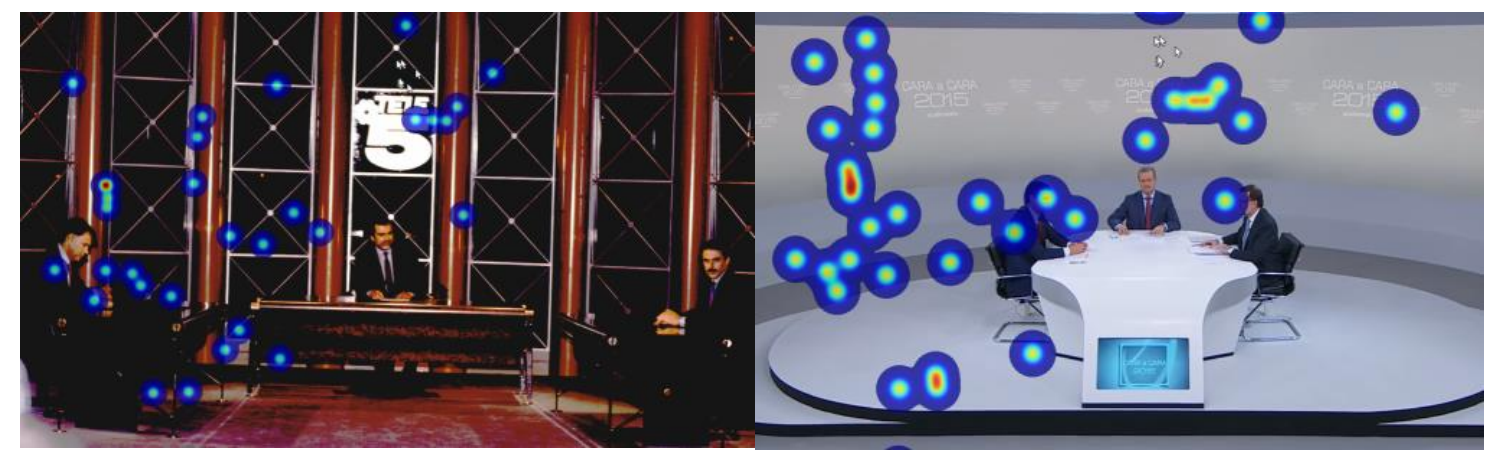

Fuente: elaboración propia

Fuente: elaboración propia

Imagen 10. Mapa de calor 2016

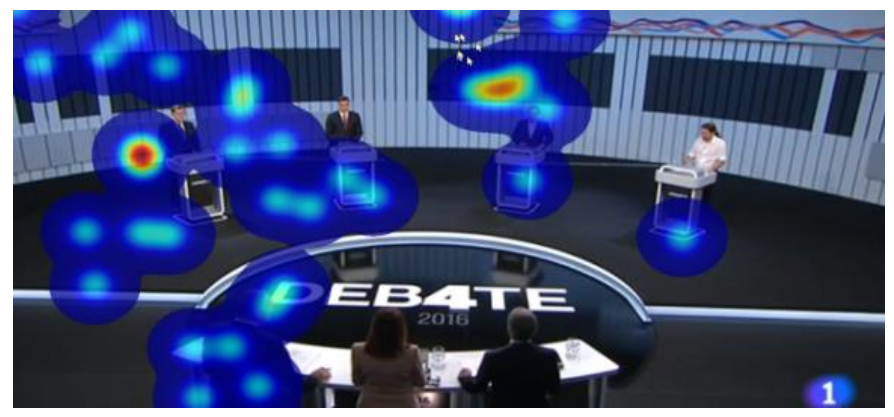

Fuente: elaboración propia

En respuesta a las preguntas del cuestionario estos son los resultados:

Gráfico 2. El debate me ha resultado interesante

"El debate me ha resultado interesante"

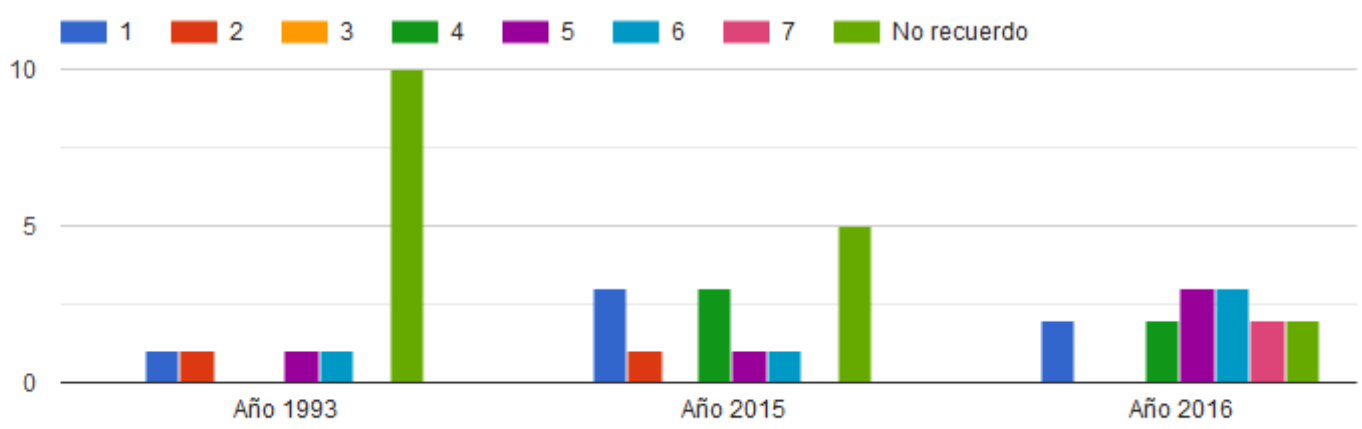


Gráfico 3. El debate ha tenido una puesta en escena atractiva "El debate ha tenido una puesta en escena atractiva"

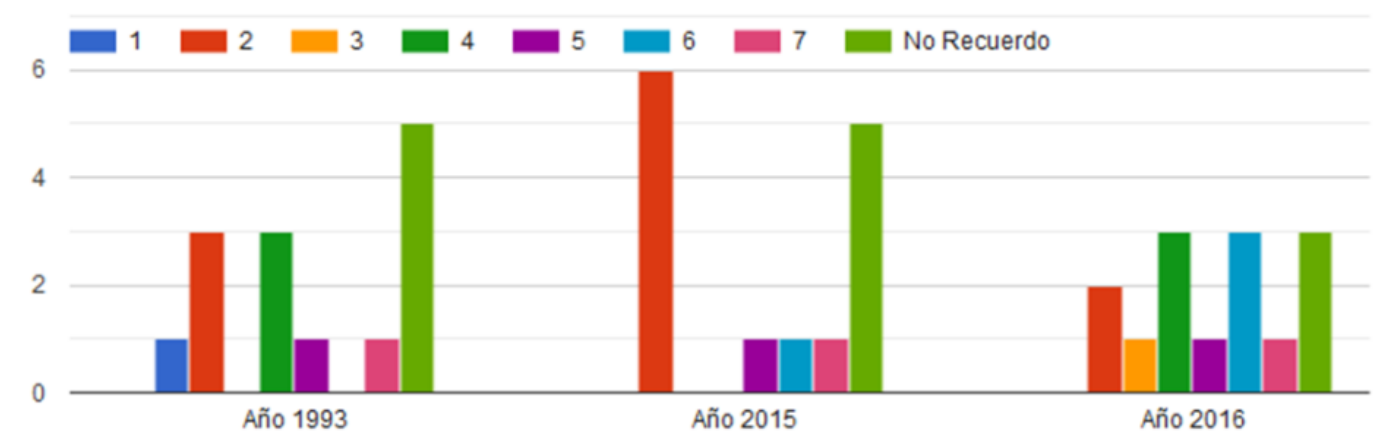

Gráfico 4. El debate ha tratado temas relevantes

"El debate ha tratado temas relevantes"

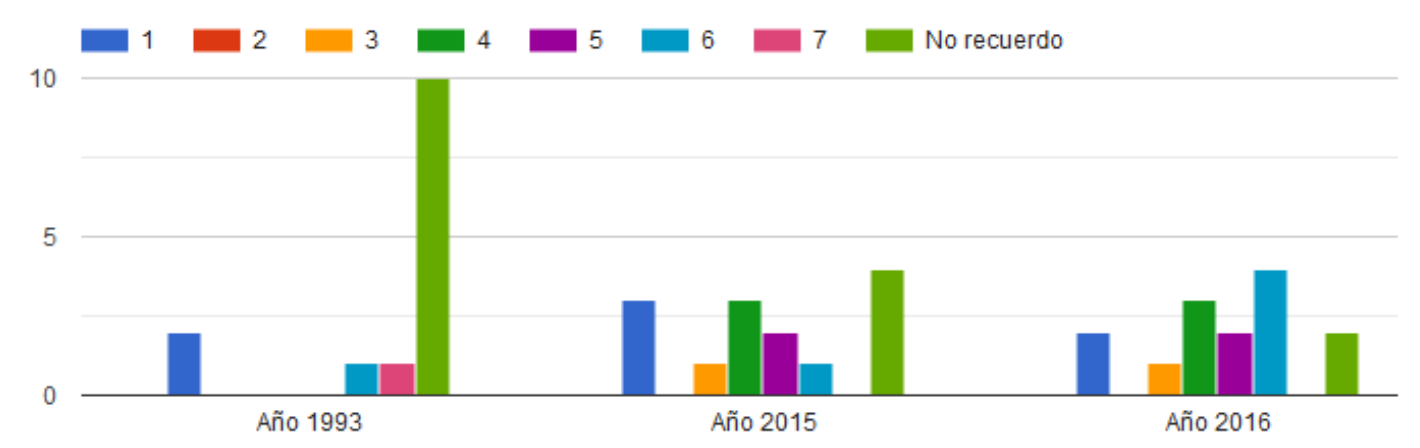

\section{Conclusiones}

Las conclusiones a las que llegamos tras el trabajo de análisis realizado son las siguientes:

En general, el formato elegido en España ha sido siempre bastante encorsetado, pero ha ido evolucionando. En concreto,

- Se ha pasado de organizar el evento en los platós de televisión de dos cadenas privadas (1993) a ser ejecutado en espacios públicos ajenos a ningún ente privado. Este hecho también 
está relacionado con los promotores del debate, siendo en el primer año las propias cadenas de televisión para, desde entonces, recaer en la Academia de Televisión.

- En los primeros debates se contaba con una escenografía bastante pobre, que se vio claramente mejorada con la irrupción de internet y los escenarios virtuales. También se ha visto una evolución en el mobiliario propio del set televisivo, evolucionando hacia líneas más rectas, menos recargadas y con colores más neutros y luminosos.

- En todos los casos y a la vista de los datos extraídos del experimento de eye-tracking, no parece que los escenarios de estos debates hayan resultado interesantes para los encuestados.

- Respecto a las distancias manejadas entre los candidatos dentro del escenario de cada uno de los debates, debemos constatar que siempre se ha mantenido una distancia social (entre los dos y tres metros), pero se ha visto claramente recortada en los últimos debates, debido a la cantidad de fuerzas políticas presentes (año 2016) y para mostrar públicamente una mayor proximidad (2015).

- La orientación de los candidatos también viene delimitada por la escenografía. Vemos claramente que, en los debates sentados, con dos candidatos, siempre se ha optado por una orientación cara a cara, de confrontación, con un presentadormoderador en medio. Ya en el debate de pie en 2016, la orientación de los personales es diferente, por el mismo motivo que señalamos antes sobre la cantidad de actores.

- En todos los debates estudiados se ha intentado generar un espacio semifijo que resulte amigable y sociópeto, pero dada la temática del debate y el necesario enfrentamiento político, resulta difícil plasmar.

- Si atendemos a la forma de mirar, es relevante que en el sorteo de quien se sitúa a qué lado de la pantalla (el posicionado a la izquierda de la misma, suscitará más atención visual).

- El debate de 1993, no se recuerda. Los debates del 2015-2016, se recuerdan y resultaron de interés para los entrevistados. 


\section{Bibliografía}

Birdwhistell, R. L. (2010). Kinesics and context: Essays on body motion communication. USA: University of Pennsylvania Press

Campbell, D. T. y Fiske, D. W. (1959). Convergent and discriminant validation by multitrait-multimethod matrix. USA: Psychological Bulletin, 56, 81G105.

Denzin,N. K. (1970). Sociological Methods: A Source Book. Chicago: Aldine Publishing Company.

Gallego, M. (2009). "Un debate transparente". En AA.VV El Debate de los debates 2008. Barcelona: Ámbit.

Gallego, M. (2012), "La profesión volcada en el debate". En AAVV Debate del debate 2011. Madrid: Dykinson.

Goldberg, J. H. y Wichansky, A. M. (2003). "Eye Tracking in Usability Evaluation: A Practitioner's Guide". The Mind's Eye. Cognitive and Applied Aspects of Eye Movement Research (23), 493-516.

Rúas Araújo, J. (2011). Manual del candidato electoral. Madrid: La Catarata. Solé, M. (1998). El protocolo y la empresa. Barcelona: Planeta Prácticos.

\subsection{Otros documentos}

Revista Academia TV. Revista de la Academia de las Ciencias y las Artes de Televisión, 104, febrero-marzo-abril 2008.

Revista Academia TV. La revista de la Academia de las Ciencias y las Artes de Televisión, 125, noviembre-diciembre 2011.

Revista Academia TV. Revista de la Academia de las Ciencias y las Artes de Televisión, 138, noviembre -diciembre 2015.

\section{Reconocimiento de la investigación}

Este artículo ha sido desarrollado al amparo del Proyecto titulado "Debates electorales televisados en España: Modelos, proceso, diagnóstico y propuesta: DEBAtv" con referencia CSO2017-83159-R de la convocatoria Proyectos de I+D+I (Retos) 2017. 



\title{
"Hasta aquí hemos llegado": análisis lingüístico y pragmático del debate entre Mariano Rajoy y Pedro Sánchez
}

\author{
Inmaculada Anaya \\ Universidade de Vigo \\ Miljana Micovic \\ Next International Business School
}

\begin{abstract}
PARA CITAR: Anaya, I. y Micovic, M. (2019). "Hasta aquí hemos llegado": Análisis lingüístico y pragmático del debate entre Mariano Rajoy y Pedro Sánchez". En Conde-Vázquez, E., Fontenla-Pedreira, J. y RúasAraújo, J. (Eds.), Debates electorales televisados: del antes al después (pp. 109-128). Cuadernos Artesanos de Comunicación, cac 154. La Laguna (Tenerife): Latina. DOI: $10.4185 /$ cac154
\end{abstract}

\section{Resumen}

Este trabajo analiza el debate entre Mariano Rajoy y Pedro Sánchez, con motivo de las elecciones del 20 de diciembre de 2015, más conocido como el 'cara a cara', desde una perspectiva funcional, pragmática y lingüística.

El estudio de algunas estrategias discursivas, de las funciones predominantes y de los recursos lingüísticos, pone de relieve la importancia del análisis para conseguir una interpretación más rigurosa de las intervenciones. Se trata de un debate en el que imperan el enfado y la beligerancia. Los ataques continuos de Sánchez y el uso de determinadas estrategias de la (des)cortesía lingüística aumentan la 
agresividad. Rajoy, por su parte, intenta ser algo más constructivo, pero sus intervenciones se centran en defenderse de los ataques de Sánchez. Del análisis realizado se deduce que el uso de las estrategias de ataque y defensa no permite que se desarrolle un debate sobre las propuestas políticas de cada candidato, sino más bien un intercambio de acusaciones.

Palabras clave: Estrategias discursivas, análisis funcional, análisis lingüístico, pragmática, debate.

\section{Introducción}

$\mathrm{E}$ L debate electoral como acto discursivo es una actividad cognitiva compleja en la que intervienen múltiples factores: el uso que se hace de la lengua, la postura de cada candidato frente al otro, las condiciones socioculturales, psicolingüísticas y pragmáticas que rodean al acto, etc. El hecho de que el 'cara a cara' sea el único debate entre ambos en toda la campaña electoral, le confiere un carácter especial, ya que las expectativas creadas en torno al mismo son máximas. Único, además, porque ambos tienen la oportunidad de dar a conocer su imagen personal y sus propuestas.

Hacia la mitad del debate, aproximadamente, se produce uno de los muchos ataques verbales que Sánchez dirige a Rajoy; concretamente, le dice que no puede gobernar "porque no es una persona decente". Esta acusación, que difiere de las demás por ser un ataque más personal que a sus políticas, es respondida por Rajoy con la frase "Hasta ahín hemos llegado, Sr. Sánchez", frase que, por su contundencia y claridad marca una antes y un después en el debate, y también, en las relaciones personales entre ambos. Si el tono del debate era bronco desde el comienzo, a partir de ese momento, la agresividad y acidez de las palabras suben hasta alcanzar límites que no se recuerdan en la corta historia de los debates electorales en España.

\footnotetext{
${ }^{30}$ Aunque en la comunicación presentada en el Congreso de la Latina, el adverbio utilizado fue aquí, hemos preferido respetar la forma que empleó Rajoy: hasta abi hemos llegado.
} 
En el caso de los debates, la televisión juega un papel muy importante. La influencia de este medio en una campaña electoral es muy alta, ya que para una buena parte de la población es el único medio de información. Se trata de eventos que obtienen una cobertura masiva y mediática, y que suscitan el interés de los ciudadanos para la carrera a la presidencia y para la política, en general. Tal como afirman McKinney y Carlin (2004: 203), los encuentros de Nixon y Kennedy en 1960 iniciaron lo que, hoy en día, es una institución firmemente establecida en las campañas electorales. Durante los pasados cincuenta años, los debates se han celebrado en muchos países democráticos del mundo, en las campañas electorales de diferentes niveles y con una gran variedad de formatos de enfrentamientos dialécticos.

Existen numerosos estudios que abordan el estudio de este género, como uno de los más interesantes en comunicación política. Kraus (1988) señala que los debates presidenciales persiguen fines democráticos y sirven a la mayoría del electorado mejor que cualquier otra herramienta de campaña. Para Schroeder (2008: 285), el debate cara a cara es el único momento en el que los principales candidatos pueden aparecer juntos en una campaña y se parecen a una entrevista de trabajo.

En España, en la campaña electoral 2015 Mariano Rajoy acudió a un único debate 'cara a cara' con Pedro Sánchez el lunes, 14 de diciembre. Al comienzo del programa, el moderador, Manuel Campo Vidal, explicó el formato del enfrentamiento y lo presentó como "un debate sin límites". Dado que una de las reglas del propio enfrentamiento televisivo era que los políticos se podían interpelar e interrumpir entre ellos, este hecho influyó en que se produjeran diálogos e interrupciones largas y, sobre todo, en algunos casos, agresivas, tal como detectamos en nuestro análisis.

El análisis que llevamos a cabo está dividido en tres partes. Partiendo del análisis funcional, hemos analizado las frases que pronuncian los candidatos para comprobar qué función predomina en cada uno de ellos. Por otra parte, desde una perspectiva pragmática, hemos averiguado qué estrategias discursivas predominan en este debate. Entre las estrategias utilizadas, hemos analizado el uso de las 
acusaciones de mentir y las interrupciones que se dan en el devenir del debate, como mecanismos lingüísticos y pragmáticos de la argumentación que influyen en el desarrollo del propio debate.

Por último, desde una perspectiva lingüística analizamos algunos recursos sintácticos y semánticos que definen no solo la personalidad de ambos candidatos, sino también, la intención, el tono, etc. de sus elocuciones.

\section{Análisis funcional}

Desde la perspectiva del análisis funcional, el objetivo es averiguar qué funciones predominan en el debate. Partimos de la Teoría Funcional de Benoit, según la cual los candidatos pueden debatir sobre un tema político (hechos pasados, planes de futuro o metas generales) o bien, sobre el candidato (cualidades personales, liderazgo, ideales). Los oponentes utilizan tres funciones que aplican tanto a los temas como al candidato: la aclamación o propuesta (acclaims), el ataque (attacks) y la defensa y refutación de los ataques (defenses).

Para Herrero y Benoit (2009: 61) el candidato que opta a la reelección utiliza más la aclamación que el ataque. En cambio, el que intenta alcanzar la presidencia es el que suele utilizar más la función de ataque. Según esta teoría, Rajoy debería haber hecho más aclamaciones; sin embargo, en este debate, a Rajoy le cuesta plantear propuestas y, a duras penas, debido a las numerosas interrupciones de Sánchez, se refiere a logros conseguidos en los cuatro años de gobierno.

Sánchez, por su parte, pierde la oportunidad de dar a conocer sus propuestas, ya que el eje central de su elocución es el ataque a Rajoy y a su política durante los años de mandato. Solo, en contadas ocasiones, en respuesta a alguna pregunta del moderador, desarrolla esta función. Por ejemplo, cuando habla de la necesidad de reformar la Constitución. Estos son algunos ejemplos:

(1) Sánchez: Usted no habla con los españoles [...] ¿Sabe cómo le conocen a usted en términos coloquiales en España, Sr. Rajoy? Como el del plasma: usted nunca ha rendido cuentas. 
(2) Sánchez: Porque usted ha faltado el respeto, ha despreciado a los estudiantes. [...] si es que usted ha despreciado también a los profesores, a los maestros de la educación pública. [...] y usted ha despreciado a los estudiantes universitarios.

(3) Sánchez: Usted no es un presidente libre [...] usted está fulminando todos los artículos del código penal.

(4) Sánchez: ¿Me escucha? Porque igual aprende algo esta noche.

Rajoy desarrolla alguna propuesta más que su rival. Además de recordar en tres ocasiones sus cuatro prioridades para España, desarrolla otras, como las siguientes: inversiones en África ("una especie de plan Marshall”); lograr acuerdos de libre comercio; darle trascendencia a las exportaciones, etc.

Para Téllez et al. (2010: 261), podría identificarse una cuarta función con el nombre de Concordancia para aquellos comentarios que tengan como fin expresar acuerdo con el otro candidato. A pesar del tono crispado en el que se desarrolla este debate, Rajoy afirma estar de acuerdo en cuatro ocasiones con su oponente: no se deben suprimir los ayuntamientos ni las diputaciones; hay que reducir el gasto de la Administración; hay que hablar de un presupuesto europeo y el respaldo al acuerdo yihadista. Esto lo verbaliza Rajoy de forma clara utilizando el verbo coincidir. "coincido con el Sr. Sánchez en [...] y coincido también en que...".

Rajoy al que le correspondería, por su opción a la reelección, hacer propuestas, centra su actuación en la defensa de las acusaciones que recibe de Sánchez, en ocasiones, atacando, como cuando dice: "Ha dicho usted muchas cosas y poco sensatas". Rajoy centra la defensa en la enumeración de datos y cifras que considera logros de su etapa de gobierno. Sobre el procedimiento de la enumeración trataremos más adelante.

\section{Estrategias de la argumentación: la acusación de mentir y las interrupciones}

Desde la perspectiva pragmática, en España se han llevado a cabo numerosos estudios sobre la (des)cortesía en los debates (Blas Arroyo 2001, 2011, entre otros; Fernández García 2000, 2009; Fuentes 2009, 
2010, Micovic, 2014). Los debates políticos representan una forma particular de la comunicación política cuyos objetivos son, en primer lugar, la eficacia comunicativa y, en segundo lugar, la salvaguarda de relaciones positivas con los demás: "alcanzar la mayor efectividad comunicativa con el menor coste posible para su imagen pública" (Fernández García, 2009: 270).

Los candidatos se plantean, desde el principio, los desacuerdos con sus interlocutores y las críticas hacia ellos o sus formaciones políticas. Los participantes en un debate suelen estar completamente seguros de su verdad y no suelen hacer concesiones a las propuestas del rival, lo que contribuye a que el desacuerdo y la crítica estén permanentemente presentes en un debate. En términos de Blas Arroyo (2001), existen unas clases de discurso, como el propio debate, en las que el comportamiento descortés representa la norma. Como también señala Fernández García (2000), el comportamiento descortés en la oposición cortesía/descortesía es el comportamiento no marcado en los debates.

\subsection{La acusación de mentir}

La acusación de mentir, acusación considerada como la más grave, es una muestra abierta de no cooperación, una de las amenazantes a la imagen del oponente y presenta un peligro grave en cualquier circunstancia, pero más todavía ante una audiencia tan numerosa como la que tiene un debate electoral (Micovic, 2014).

Como observamos en los ejemplos extraídos del debate 2015, tanto Sánchez como Rajoy utilizan en numerosas ocasiones esta estrategia. Muchos de los argumentos principales esgrimidos por los dos políticos se encuentran reforzados o rebatidos mediante la estrategia descortés de acusar al contrincante de decir falsedades o de exigirle que diga la verdad. Para formular esta acusación, los candidatos usan distintos términos léxicos, como puede observarse en los siguientes ejemplos del discurso de Sánchez:

(5) Es verdad que durante estos 4 años lo que ha hecho es mentir a los españoles desde su acción del Gobierno.

(6) Usted presume de que su gran logro ha sido evitar el rescate. Y es mentira, Sr. Rajoy. 
(7) No es verdad, Sr, Rajoy.

(8) No es cierto, no es cierto; lo siento, pero no. No es cierto.

(9) (...) así que diga usted la verdad, Sr. Rajoy, diga usted la verdad.

Como puede observarse, en los ataques más directos, Sánchez usa el verbo mentir (ej. 5) y el sustantivo mentira (ej. 6); mientras que en el ejemplo $n^{\circ} 7$, Sánchez suaviza la afirmación diciendo no es verdad y en el ejemplo $\mathrm{n}^{\circ} 8$ no es cierto, usando también, en este caso, el mecanismo de la repetición. En el ejemplo $n^{\circ} 9$ puede observarse otra manera más indirecta de la acusación de mentir: la exigencia a que el rival diga la verdad. Podemos afirmar que la elección del léxico que utiliza Sánchez para formular esta acusación se corresponde con la tensión y la beligerancia en cada momento del diálogo mantenido entre los candidatos.

Por su parte, Rajoy también recurre a esta acusación en los siguientes ejemplos:

(10) No, no, no es verdad. No le acepto esa afirmación.

(11) Sr. Sánchez, conviene decir la verdad.

(12) No he recortado derechos, es falso.

(13) Eso es una absoluta falsedad. (...) Mire, eso es mentira. (...) que no es verdad, que no se lo acepto.

Del análisis se deduce que Rajoy recurre con más frecuencia a las palabras falso y falsedad (ej. 12 y 13), y exige al rival, en mayor medida, que diga la verdad, además, usando la forma impersonal (ej. 11). Otra forma de defenderse Rajoy de este ataque es la frase: No le acepto esa afirmación (ej. 10 y 13), que aparece en repetidas ocasiones en el debate. Como ya hemos comentado, queda reflejado en los ejemplos analizados que la acusación de mentir se formula frecuentemente usando el mecanismo lingüístico de la repetición.

\subsection{Las interrupciones}

El debate, por su naturaleza polémica, representa un contexto en el que es más probable que se produzcan interrupciones que en otro tipo de géneros políticos televisados (Blas Arroyo, 1998; Fernández García, 2000). Las interrupciones son amenazas contra la imagen positiva de quien las sufre. Son muestras abiertas de no cooperación por parte de quien las realiza, ya que este invade el espacio del interlocutor, su 
'espacio conversacional', el término que viene de Brown y Levinson (1987, apud. Fernández García 2000: 150).

El objetivo principal de las interrupciones es intentar evitar que el oponente transmita sus argumentaciones, obstaculizar la transmisión de mensajes completos. Es interesante también observar el comportamiento que mantienen las dos partes ante esta situación, es decir, cómo las realizan los que interrumpen y cómo reaccionan los interrumpidos. Si el interrumpido rechaza la interrupción, puede hacerlo de dos formas, tal y como explica Fernández García (2000:161), siguiendo a Bañón (1997: 51): por la neutralización, el intento de contrarrestar la interrupción, repitiendo el fragmento de elocución que se está interrumpiendo, elevando el tono, etc.; y por la sanción, que es el rechazo explícito; este puede producirse de forma mitigada para echar cordialmente al interlocutor de su espacio, por ejemplo, pidiendo perdón.

En nuestro análisis observamos las apariciones de las interrupciones y las reacciones de los candidatos frente a éstas en el debate de la campaña 2015.

En primer lugar, cabe destacar que las interrupciones aparecen con mucha frecuencia en el 'cara a cara'. Los interlocutores se interrumpen uno al otro continuamente en aquellos puntos de su argumentación con los que no están de acuerdo. En segundo lugar, los tiempos que se permiten los interlocutores hablar sin interrupciones disminuyen conforme avanza el debate.

Hemos comprobado que, en el primer bloque, las interrupciones ya son frecuentes y crean un ambiente tenso y beligerante. Encontramos la primera interrupción significativa de Sánchez en la intervención de Rajoy, en la que este, primero, recurre a la neutralización porque sigue con su elocución, elevando el tono de la voz, pero al final responde al interlocutor:

(14) Rajoy: España estaba al borde de la quiebra.

Sánchez: No es cierto.

Rajoy: La prima de riesgo...

Sánchez: No es cierto 
Rajoy: Sí, sí, estaba muy elevada.

A continuación, se producen dos interrupciones breves, ejemplo (15), en las que Rajoy reacciona respondiendo y recuperando su turno; en cambio, en el ejemplo (16) la interrupción no altera el turno de palabra y Rajoy continua con su intervención:

(15) Rajoy: Porque desde el principio desde el $2014 \ldots$

Sánchez: Mire, Sr. Rajoy...

Rajoy: Sí, sí, porque a usted no le importa, pero a mí sí.

(16) Rajoy: Realmente tiene usted una imagen muy negativa de su país.

Sánchez: No.

Rajoy: (...) que es el mío también.

En los ejemplos (17), (18) y (19) encontramos interrupciones en las que el interrumpido sanciona explícitamente al que le interrumpe con un "no me interrumpa" o "déjeme terminar":

(17) Sánchez: ¿Pero hubo un rescate, Sr. Rajoy?

Rajoy: ...subir al 23\% el IVA en hostelería.

Sánchez: ¿Hubo un rescate, sí o no?

Rajoy: No, no hubo rescate, se lo estoy explicando, pero no me interrumpa. (18) Sánchez: Eso...

Rajoy: ¿Sabe usted cuantos son los gastos de España en pensiones?

Sánchez: Déjeme terminar, déjeme terminar...

(19) Sánchez: Usted tendría que haber dimitido hace dos años.

Rajoy: Sí, ya me lo dijo.

Sánchez: ¿Pero me deja terminar, me deja terminar?

Por último, cabe señalar la relación entre las acusaciones de mentir y las interrupciones, dos de las estrategias que analizamos en esta investigación. Precisamente es en las interrupciones donde aparecen con más frecuencia las acusaciones de mentir en el debate. En el ejemplo (20), en el que se produce el diálogo más largo de todo el debate, los candidatos se ven obligados a sancionar al interlocutor y el moderador intenta intervenir, pero los políticos no tienen en cuenta su intervención y siguen su diálogo descortés:

(20) Sánchez: No mienta a los españoles, Sr. Rajoy, no mienta a los españoles. Rajoy: No, el que miente es usted. 
Sánchez: No, permíteme...Y no diga usted que ha bajado el IRPF a los trabajadores, hombre, que están pagado 17,500 millones de euros más que hace 4 años, Sr. Rajoy.

Rajoy: Claro que se lo hemos bajado, por favor, pero sí que ha habido rebajas de impuesto e personas físicas.

Sánchez: Déjeme hablar que ahora es mi turno, Sr, Rajoy, ahora es mi turno.

Rajoy: Sí, sí, pero es para aclarar una cosa, aquí ha habido dos rebajas de IRPF este año 2015, lo niegue usted.

Sánchez: No, no.

Rajoy: Si todo lo que usted dice es tan cierto como eso, tiene usted un problema.

Sánchez: ¿Sabe a quién ha bajado los impuestos?

Rajoy: Nosotros...

Sánchez: A los beneficiarios de la amnistía fiscal, a sus compañeros del Partido Popular.

Rajoy: Eso es absolutamente falso. Hemos bajado los impuestos a todos los españoles.

Moderador: Tiempo para el Sr. Rajoy.

Sánchez: Déjeme decir una cosa, Sr, Rajoy, 17.500 millones de euros más que pagan en impuestos los españoles.

Rajoy: Eso es falso.

\section{Análisis lingüístico}

En esta parte del estudio, analizamos el debate desde un punto de vista sintáctico y semántico. Para ello nos hemos centrado en algunos aspectos concretos, como el uso de los pronombres personales, el modo imperativo, la enumeración como operación textual, la recurrencia léxica y alguno de los conectores empleados en este debate (pero, por tanto y por eso). Asimismo, comentamos algunos recursos retóricos por su fuerza expresiva. Para Cantavella et al. (2008: 84) el uso de determinados recursos lingüísticos y retóricos está directamente relacionado con la finalidad de persuadir al oyente.

Desde el primer momento, Sánchez intenta mostrar la divergencia que existe entre él y su opositor con afirmaciones como "No somos lo mismo, somos lo contrario". La diferencia entre ambos se extiende al 
plano personal y, más concretamente, al generacional, ya que, como señala Schroeder en un artículo publicado tras el debate ${ }^{31}$ :

A veces, la interacción parecía más una discusión entre un padre y su hijo en plena cena, cada uno de ellos totalmente convencido de llevar la razón.

Después de que Sánchez le dijera a Rajoy que no era "un político decente", Rajoy le responde que él es "un político honrado" y añade, en alusión a la edad: "Usted es joven...". Justo antes de pasar al último bloque, Sánchez le dirige un ataque, también relacionado con la edad: "A usted esto le suena a chino porque es un político del siglo pasado".

En opinión de Leanne (2009: 80) personalizar el mensaje a través de los pronombres personales ayuda a que el mensaje sea más eficaz. Sánchez, después de la defensa que hace Rajoy sobre su honradez, dice lo siguiente: "Esto va ¿de usted o de yo?". Aunque la frase no está bien formulada, es evidente que Sánchez quiere marcar la diferencia, en este caso, con los pronombres. Son numerosos los ejemplos en los que se hace uso del pronombre personal para reafirmar la seguridad del enunciado y mostrar cierto dominio sobre el oponente. Estos son algunos casos:

(21) Sánchez: Usted lo que ha hecho es recortar todo menos la corrupción

(22) Sánchez: Usted ha roto el pacto educativo

(23) Rajoy: Yo soy un político honrado

(24) Rajoy: Usted va a perder las elecciones

(25) Rajoy: Nosotros vamos a crear dos millones de puestos de trabajo

Además de los pronombres personales, en los debates también juega un papel importante la función de la enumeración. Para Montolío (2005: 252), esta operación textual permite realizar diferentes sub-operaciones discursivo-cognitivas, como parcelar datos, agruparlos bajo un tema global, visualizar los elementos enumerados, etc. La enumeración ayuda a que el público aprehenda la información interpretándola como un todo coherente.

${ }^{31}$ Alan Schroeder colgó en su blog un artículo muy interesante titulado "La agresividad le salió cara a Pedro Sánchez” el 16 de diciembre de 2015. 
Al comienzo de este debate, el moderador, Campo Vidal, explica que el debate consta de cuatro partes. De esta manera, los espectadores saben, en cada momento, en qué parte del debate están. Una enumeración bien formulada ayuda a comprender mejor el mensaje y propicia la comunicación eficaz. Sánchez inicia su intervención enumerando los cuatro desafíos que para él tiene la cuestión del empleo:
1. La falta de oportunidades
2. La desigualdad
3. La falta de confianza en las instituciones y la corrupción
4. La convivencia en Cataluña

Rajoy emplea en numerosas ocasiones este procedimiento y elige también el número cuatro para referirse a sus cuatro grandes objetivos o prioridades que repite tres veces a lo largo del debate. Estas son sus cuatro prioridades:

1. La lucha contra el desempleo

2. Las pensiones y los servicios públicos

3. La lucha contra el terrorismo

4. La defensa de la unidad nacional

También son cuatro las cuestiones innegociables, según Rajoy:

1. La unidad de España

2. La soberanía nacional

3. La igualdad de todos los españoles

4. El cumplimiento de la Ley

La enumeración, además de aportar claridad y concisión al discurso, permite retener con mayor facilidad las ideas y los datos.

Si nos fijamos en los verbos, el modo imperativo es uno de los más empleados por ambos candidatos: aclare, no mienta, explíqueme, conteste a mi pregunta, diga la verdad, etc. El imperativo se utiliza para solicitar algo de alguien y tiene, con frecuencia, un valor de 'obligación'; en este caso este valor es claro y provoca una determinada conducta en el interlocutor, no siempre cómoda, ya que este, en cierto modo, se siente continuamente presionado por el que habla; el tono de este debate favorece que sea este un modo verbal muy usado. 
Entre los recursos lingüísticos que contribuyen a dar coherencia y cohesión nos hemos fijado en dos de los utilizados por los candidatos: la progresión temática y los marcadores del discurso. Compartir unos referentes sociales, culturales, etc., asegura un grado de continuidad en el debate; en este sentido, la progresión temática es un recurso que permite que la información se entienda. En un momento determinado, Sánchez le dice a Rajoy que "lo que dice es digno de ser investigado por Cuarto Milenio". Para entender este mensaje es necesario saber que Cuarto Milenio es un programa de televisión de la cadena Cuatro, que trata temas envueltos en misterio sobre parapsicología, demonología, ocultismo, etc. Si no se comparte ese conocimiento, el mensaje no se entiende.

Otro procedimiento de conexión en el debate son los llamados conectores o marcadores del discurso. Se trata de elementos lingüísticos especializados en conectar frases (Montolío, 2015: 20). Según esta autora, los marcadores señalan con qué sentido van encadenándose en la frase los diferentes fragmentos; algo parecido a lo que sucede con las señales de tráfico. Entre los marcadores discursivos empleados en este debate, hemos analizado el conector contraargumentativo, pero por ser el más utilizado. Rajoy lo emplea con frecuencia, como en el siguiente ejemplo:

(26) Rajoy: Habla usted de dependencia, pero los datos de la dependencia dicen que la inversión que se ha producido en estos años...

Muy significativo el uso que hace Campo Vidal. El moderador se da cuenta de que los dos candidatos están inmersos en una batalla verbal que hace que, entre otras cosas, sean incapaces de terminar, en este caso, con el tercer bloque. Es entonces cuando dice: "Terminemos, pero terminemos de verdad". La conjunción adversativa, pero pone de manifiesto la intención decidida del moderador de acabar con ese bloque, pese a que los políticos parecen no oírle, ya que no le hacen caso.

Otros conectores son por tanto y por eso, en este caso, con valor consecutivo. Rajoy emplea en más de una ocasión el conector, por tanto:

(27) Rajoy: Hemos reducido la lista de espera a la mitad. Por tanto, le ruego a usted que diga la verdad. 
Sánchez emplea el marcador por eso en la intervención final. Habla de bienestar social, del paro, de la igualdad... y antes de pedir el voto, refuerza su argumentación con este conector que funciona como causa desencadenante:

(28) Sánchez: España necesita un cambio para mejorar [...] Por eso, nosotros lo hicimos en el pasado...

En los debates, como ocurre en política y en la vida en general, el peso de las imágenes es importante, de ahí que el uso de figuras retóricas sea habitual. En este caso, el uso de las metáforas es compartido por ambos candidatos. Romo (2005: 69) explica el concepto de 'metáfora' que consiste en trasladar la palabra de su sentido propio al figurado; esta traslación conlleva siempre una semejanza que es lo que permite establecer la relación entre ambas: 'ver algo como algo', "movimiento del espíritu que es el mismo que nos permite formar conceptos".

En respuesta a unas acusaciones de Sánchez, Rajoy dice: "Cuando llegamos al Gobierno, España estaba al borde del rescate: éramos el enfermo de Europa". Para entender el valor de la palabra enfermo es necesario conocer el contexto económico en el que se encontraba España en ese momento. Según Rajoy, y por eso utiliza esta metáfora, el número de parados ascendía a "tres millones cuatrocientos mil". En definitiva, según el líder del Partido Popular, estábamos ante una fuerte crisis que abocaba a España al rescate. En la respuesta, Sánchez, por su parte, le reprocha que hable de milagro económico con objeto de ridiculizar la "sorprendente recuperación" que, según Rajoy, ha vivido el país.

Para Vico (2005: 210), "son más brillantes las metáforas que se hacen de verbos que las de nombres". En el segundo bloque del debate, el dedicado al Estado del Bienestar, Sánchez utiliza la metáfora para resaltar la gravedad de los hechos:

(29) Sánchez: Usted, Sr. Rajoy, ha paralizado la ley de Dependencia [...] ha suprimido la cotización social a los cuidadores [...] estos son algunos de los recortes que usted ha perpetrado.

Perpetrar, según la RAE, es "cometer un delito grave"; la dimensión que adquieren los hechos relatados por Sánchez con el uso de este verbo 
es evidente. Un poco más adelante, Sánchez vuelve a utilizar la metáfora, esta vez, con el término real y el término metafórico en la misma frase para lograr una mayor expresividad: "Usted ha convertido la prestación del Estado en limosna del Gobierno". Estos son otros ejemplos de Sánchez:

(30) Usted ha permitido destruir a martillazos el ordenador de Bárcenas

(31) No retuerza mis palabras

(32) Usted ha fulminado todos los artículos del código penal

(33) Usted hizo siete buenas intenciones sobre el Estado de Bienestar que se han convertido en sus siete pecados capitales.

Además de la metáfora, aparecen otras figuras como la metonimia, donde según Romo (2005: 71) se da una contigüidad real entre ambos términos. Sánchez, al hablar de la subida de impuestos dice lo siguiente: "usted ha subido el impuesto de las chuches de los niños". La ironía es otra de las figuras que aporta riqueza al debate. Rajoy sabe hacer uso de este recurso que consiste en emplear una palabra con un significado contrario al propio: "las reformas no producen efectos en un cuarto de hora". Con esta imagen trata de ridiculizar a Sánchez por su falta de conocimiento en la materia.

El epíteto está presente en muchos momentos porque suele actuar como intensificador de la idea que se quiere transmitir. Estos son algunos ejemplos: desempleo descomunal, España tenebrosa, actuación ruin, mezquina y miserable, etc. Tampoco faltan algunos ejemplos de eufemismos, como el llamado paro estructural.

La yuxtaposición de ideas u oposición de contrarios permite al candidato situar ideas opuestas, una al lado de la otra, y realzar los puntos clave mediante la oposición y el contraste. Es lo que sucede en el siguiente ejemplo, en el que Rajoy utiliza este recurso para referirse a cómo estaba la situación cuando llegaron al gobierno:

(34) Rajoy: Antes, 1.500 españoles perdían el puesto de trabajo al día/Ahora, 1.400 españoles encuentran un puesto de trabajo al día

Para Luengo (2011:86), las estrategias discursivas más efectivas durante un debate son precisamente "aquellas que apelan a lo emotivo y se 
circunscriben a lugares comunes" (2011: 93). También Berrocal insiste en esta idea cuando afirma que "el fenómeno choca contra los principios de la participación democrática porque se deja de lado la argumentación para promover la llamada a lo emocional" (2003: 227).

El análisis de las estrategias discursivas corrobora la relación existente entre el uso adecuado de algunos recursos lingüísticos y la recepción del mensaje (Anaya, 2014:27). En este sentido, el lenguaje empleado por Rajoy se percibe en el análisis como más positivo que el de Sánchez. Rajoy realiza afirmaciones como las siguientes: "España es la nación europea que más tiempo llevamos viviendo juntos"; "soy optimista respecto al futuro de España" e, incluso, acusa a Sánchez de querer transmitir una idea negativa de España: "Usted lo que quiere es pintar una España tenebrosa". Por otra parte, el uso de eslóganes, como "Somos un gran país", eslogan que ya había empleado Rajoy en la campaña anterior con Zapatero, ayuda a reforzar el mensaje de querer transmitir confianza y optimismo, sentimientos ambos, muy importantes en campaña electoral.

\section{Conclusiones}

El análisis lingüístico y funcional del debate aporta una serie de datos que definen no solo la visión política de los candidatos, sino también, la personalidad de cada oponente. El ataque exagerado de Sánchez le perjudica ya que, al centrarse en criticar, apenas realiza propuestas de futuro. Su tono bronco y el uso excesivo de expresiones negativas hacen que, en general, la opinión sobre su intervención sea negativa. Rajoy no realiza un buen debate, porque lejos de poder desarrollar las propuestas que su partido tiene para los próximos años, tiene que afanarse en defenderse. Aun así, realiza algunas propuestas concretas que repite en varias ocasiones y deja claras también cuáles son sus prioridades.

Aunque el debate permite que los candidatos se interrumpan, las interpelaciones de Sánchez llegan a resultar groseras y de mal gusto. El análisis lingüístico (los pronombres personales, el modo imperativo, la enumeración, el conector pero, etc.) viene a corroborar esta misma idea. La presencia de metáforas, metonimias, epítetos y otras figuras 
retóricas son un reflejo, no solo del ingenio de los grupos encargados de preparar el debate y de la cultura de un país, sino también, del poder que tienen las imágenes descritas con palabras.

Además, a través del análisis pragmático de la (des)cortesía hemos comprobado, por un lado, que en el debate de 2015 las constantes interrupciones influyeron en el desarrollo del propio debate provocando un ambiente de mucha tensión entre los candidatos. Por otro lado, los constantes ataques formulados por Sánchez fueron llevados a cabo, en la mayoría de los casos, mediante la acusación de mentir, expresada de manera más directa en momentos de mucha tensión, y de manera atenuada e indirecta, en los momentos menos beligerantes. Cabe resaltar también que esta estrategia fue usada por ambos candidatos y que es precisamente en las interrupciones, en los diálogos más largos, donde aumenta la frecuencia de uso de la acusación de mentir.

En definitiva, en el desarrollo de los debates influyen las reglas preestablecidas, esto es, el formato de un debate abierto en el que está permitido interpelar e interrumpir al adversario, cuestión que puede influir en la argumentación de cada uno de los participantes en el enfrentamiento. No obstante, cómo van a transcurrir la discusión y el diálogo en una lucha verbal siempre va a depender de la estrategia que quieran emplear los candidatos que participen en el debate.

\section{Bibliografía}

Anaya, I. (2014). "El análisis del discurso protocolario: elaboración y conceptualización”. Estudios filológicos, 54, 7-29.

Bañón, A. M. (1997). La interrupción conversacional. Propuestas para su análisis pragmalingüistico. Málaga: Analecta Malacitana.

Berrocal, S. (2003). "Comunicación política en televisión y nuevos medios". Doxa Comunicación, 2, 227-230.

Blas, J. L. (1998). "Pero no me interrumpa usted, haga el favor. Las interrupciones en el debate político-electoral". Mediterranean Language Review, 10, 54-88. 
Blas, J. L. (2001). "No diga chorradas: La descortesía en el debate político cara a cara. Una aproximación pragma-variacionista". Oralia, 4, 9-45.

Blas, J. L. (2011). Políticos en conflicto. Una aproximación pragmático-discursiva al debate electoral cara a cara. Berna: Peter Lang.

Brown, P. y Stephen, C. L. (1987). Politeness. Some Universals in Language Use. Cambridge: Cambridge University Press.

Cantavella, J., Bullough, R., Curiel, L., Morales, B., Mejía, C. y Pittaro, E. (2008). "Algunos aspectos lingüísticos de los debates electorales Zapatero-Rajoy 2008”. Estudios sobre el Mensaje Periodístico, 79-98.

Fernández, F. (2009). “(Des)cortesía y pugna dialéctica en el debate político-electoral". Oralia, 12, 267-304.

Fernández, F. (2000). Estrategas del diálogo. La interacción comunicativa en el discurso politico-electoral. Granada: Método-Ediciones.

Fuentes, C. (2009). "El debate entre Zapatero y Rajoy: ¿convencer a quién? Estudio textual e interactivo". Tonos Digital, 18.

Fuentes, C. (2010). "Le voy a decir una cosa, pero no me diga usted...: el derecho a la palabra". En Orletti, F. y Mariottini, L. (eds.), Descortesía en español. Espacios teóricos y metodológicos para su estudio. Roma, Estocolmo: Università degli Studi Roma, 87-110.

Herrero, J. C. y Benoit, W. (2009). "Análisis funcional de los debates en las elecciones generales de 2008". Zer, 14(27), 61-81.

Kraus, S. (1988). Televised presidential debates and public policy. New Jersey: Lawrence Erlbaum Associates.

Leanne, S. (2009). Hablar como Obama. Barcelona: Profif.

Luengo, O. G. (2011). "Debates electorales en televisión: una aproximación preliminar a sus efectos inmediatos", en Revista Española de Ciencia Política, 81-96.

McKinney, M. y Carlin, D. (2004). "Political Campaign Debates". En Kaid, L. (ed.), Handbook of Political Communication Research. New Yersey: Lawrence Erlbaum Associates, 203-234.

Micovic, M. (2014). La comunicación y el discurso políticos en España y Serbia. Análisis comparativo de las estrategias argumentativas utilizadas en los debates electorales televisivos. Tesis doctoral. Disponible en: http://diposit.ub.edu/dspace/handle/2445/62703

Montolío, E. (2005). Conectores de la lengua escrita. Barcelona: Ariel. 
Montolío, E. (2005). "Formación en técnicas de comunicación escrita dirigida a ingenieros de informática. El caso de la marcación de la operación textual de la enumeración". Lingüistic Insights: Studies in language and communication, 44, 248-279.

Rodríguez, C., Romo, F. y Anaya, I. (2005). Vico. Elementos de retórica: El sistema de estudios de nuestro tiempo y Principios de oratoria. Madrid: Trotta.

Romo, F. (2005). La retórica: un paseo por la retórica clásica (Montesinos). Barcelona: Intervención cultural.

Schroeder, A. (2008). The Presidential Debates: fifty years of high-risk TV. New York: Columbia University Press.

Téllez, N., Muñiz, C. y Ramírez, J. (2010). "Función discursiva en los debates televisados. Un estudio transcultural de los debates políticos en México, España y Estados Unidos”. Palabra Clave, 13(2), 251-270.

\section{Reconocimiento de la investigación}

Este capítulo forma parte de los trabajos desarrollados en el marco del proyecto de I+D+I (Retos) "DEBATv, Debates Electorales Televisados en España: Modelos, Proceso, Diagnostico y Propuesta" (Ref. CSO2017-83159-R), financiado por el Ministerio de Economía, Industria y Competitividad (MINECO), la Agencia Estatal de Investigación (AEI) y el Fondo Europeo de Desarrollo Regional (FEDER) de la Unión Europea (UE). 



\title{
El rol de los periodistas como entrevistadores en los debates presidenciales
}

\author{
Enrique Núñez Mussa \\ Universidad Pontificia Católica de Chile
}

\begin{abstract}
PARA CITAR: Núñez, E. (2019). "El rol de los periodistas como entrevistadores en los debates presidenciales". En Conde-Vázquez, E., Fontenla-Pedreira, J. y Rúas-Araújo, J. (Eds.), Debates electorales televisados: del antes al después (pp. 129-149). Cuadernos Artesanos de Comunicación, cac 154. La Laguna (Tenerife): Latina. DOI: 10.4185/cac154
\end{abstract}

\section{Resumen}

Desde la primera aparición del panel de periodistas en los debates de Nixon y Kennedy, en que actuaron como entrevistadores, se ha discutido su participación en estos encuentros y cómo debiese ser. Este capítulo hace una revisión de los argumentos a favor y en contra de la participación de los periodistas en debates presidenciales televisados, dando cuenta de que estos no han avanzado desde 1960 hasta la actualidad, estando aún anclados a la opinión antes que a la evidencia científica.

Por lo tanto, se propone un marco de investigación dentro de la línea de roles periodísticos, con la construcción de cuatro roles a identificar en debates presidenciales televisados, que puedan aportar a entender y evaluar la participación de los periodistas en dicha instancia democrática: un rol cívico ideal, watchdog o perro guardián de la verdad, antagonista o adversario, y estratégico. 
Palabras clave: Roles periodísticos, debates presidenciales televisados, periodistas en debates presidenciales, cívico, watchdog, adversario, estratégico, moderadores en debates, panelistas en debates.

\section{Introducción}

I OS periodistas debutaron como entrevistadores en los debates 1 presidenciales televisados en el primero de la historia, que inauguró los cuatro encuentros entre John F. Kennedy y Richard Nixon en 1960. Autores como Sidney Kraus (1962, 2000), Alan Schroeder (2016) y Lanoue y Schrott (1991) han llevado a cabo una cuidada documentación del proceso que condujo a la implementación del panel de periodistas en ese debate, por lo que acá sólo se extraen hitos clave de forma sintética.

Mientras los canales de TV buscaban mayor confrontación y, a la vez, control sobre las interacciones, con un formato conocido como el debate de Oregón, que sólo exigía intercambio entre los contendores; los candidatos y sus equipos temían al enfrentamiento y que ese formato fuese poco atractivo. Eso llevó a 12 reuniones de negociación en las que fueron, finalmente, los equipos de campaña los que empujaron por incluir periodistas, ante la conformidad, no así el agrado de los canales de televisión, cuyos ejecutivos se convencieron, porque podrían influir en la selección de los entrevistadores.

De los argumentos que se dieron para incorporar periodistas, el primero fue contextual. En 1960, la Guerra Fría era un asunto delicado, había temor de que una discusión agresiva entre los candidatos generase que alguno perdiera el control y que un enunciado pudiese conducir a una crisis política internacional, algo que los periodistas podrían mantener bajo control (Seltz y Yoakam, 1962).

Los demás argumentos, aun cuando tenían la intención de atenuar los riesgos de exponer a los candidatos, porque ya estaban acostumbrados a responder entrevistas y participar en conferencias de prensa, también 
revelan las cualidades que, ya entonces, se asociaban a la profesión periodística y su rol en la sociedad.

Los equipos de los candidatos pensaban que los periodistas serían imparciales, basados en la norma profesional de ser objetivos, lo que aportaría a garantizar un debate equilibrado (Lanoue y Schrott, 1991). Además, tras seguir la campaña, los periodistas ofrecerían la capacidad de verificar los datos en las afirmaciones de los candidatos, así se mantendría un estándar de precisión (Seltz y Yoakam, 1962).

Con la emisión de los encuentros, la participación de los periodistas se tornó parte de la discusión pública. Originalmente no tuvo una buena acogida por la audiencia. Hay que considerar que aún no ocurría el caso Watergate, que dotó al periodismo de una nueva cualidad ante la ciudadanía, respecto a su capacidad de enfrentar al poder.

La comisión de la Asociación Americana de Ciencias Políticas recibió cartas de congresistas que criticaban el panel, porque consideraban que los periodistas interferían en la comunicación entre los candidatos y la audiencia (Kirkpatrick, 1979). En encuestas realizadas a personas que vieron los encuentros, una de las sugerencias que se repitió fue la de eliminar a los periodistas que hacían las preguntas (Coleman, 2000), misma sugerencia que obtuvo Carter (1962), quien encuestó a republicanos y demócratas.

La inclusión del periodista ha llevado a que una de las críticas comunes a los debates televisados sea que no son en realidad debates, sino entrevistas aisladas sobre temáticas dispersas o conferencias de prensa. Además de la ya mencionada, Coleman (2000) sintetiza las críticas más frecuentes que se han repetido a lo largo de los años respecto la participación de periodistas en los debates televisados: intentan encontrar las debilidades de los candidatos; su agenda no necesariamente representa a la de los ciudadanos; y se incluye una variedad tan amplia de temas que los candidatos no pueden profundizar en ninguno.

La participación de periodistas también ha levantado defensores. Robert Sarnoff (1962), productor de la NBC para los encuentros entre 
Nixon y Kennedy considera que los periodistas tienen la capacidad de visibilizar temas y conseguir que los candidatos expongan su posición sobre los mismos. Dice, además, que se evita la diplomacia y formalidades para que se privilegie la presentación de ideas.

Martel (1983) entrega tres argumentos para defender la participación de los periodistas: primero, facilitan que los candidatos estén dispuestos a participar, porque solo deben ser capaces de responder preguntas y no tienen que ser buenos formulándoselas a sus rivales. Este argumento es discutible, ya que el periodista, entonces sería utilizado por los equipos de campaña para cubrir las debilidades de su candidato. En parte, la intención original de su inclusión en 1960.

Se compensa con el segundo, ya que la figura del periodista, puede también ser un factor de incomodidad al introducir temas que los candidatos de otra manera podrían evitar; y, por último, pueden aportar a mantener el debate enfocado en los temas que importan al electorado, para que la instancia no se convierta en una confrontación de personalidades.

Stepp (1987) propone que el debate presidencial televisado sea entendido como un género híbrido. En lugar de debates prefiere llamarlos foros de campaña y los describe como una combinación entre la conferencia de prensa, la entrevista y un debate tradicional. Desde esa mirada, la participación del periodista es parte del género $y$, por ende, aporta, porque el debate es en sí mismo un producto periodístico.

Eso no implica que no se genere contraposición entre candidatos, al revés, el debate televisado es un espacio que otorga una oportunidad masiva al público para comparar perspectivas y propuestas, y verlos desenvolverse en un ambiente espontáneo, facilitado por las intervenciones de los periodistas.

Aunque la tradición nace en Estados Unidos, las consideraciones aquí expuestas trascienden sus fronteras. El impacto mediático que tuvieron los primeros debates llevó a que el formato con panel de periodistas fuese exportado. En la década de los 60, Alemania Occidental, Suecia, 
Finlandia, Italia y Japón probaron formatos parecidos, por nombrar algunos casos (Mickelson, 1972).

El panel de periodistas aún está en uso en diferentes países, por ejemplo, en América Latina, continente que por las dictaduras que rigieron en la década de los 70, desarrolló una tradición tardía de debates presidenciales televisados (Ruiz y Alberró, 2012), adoptando el modelo de Nixon-Kennedy, aunque este se dejó de usar en los Estados Unidos en 1992, donde se mantiene la figura del periodista como moderador combinado con formatos de town hall o plaza pública.

Ya sea como moderadores o panelistas, son los periodistas desde la experiencia, quienes han ido definiendo su rol en los debates. Como expone Schroeder (2016), algunos deliberadamente han querido aparecer más neutrales, mientras otros han decidido ser más agresivos o cuestionadores.

La discusión reflotó para la elección presidencial de Estados Unidos en 2016, pero fue a través de la prensa y no de la investigación académica. Una columna publicada en la NPR se planteó nuevamente: "Tal vez, los periodistas no pertenecen a los debates presidenciales" 32 , lo que muestra que la conversación no ha avanzado. Ejemplo de lo mismo es un artículo publicado en Vox, en el que uno de los moderadores define que no es su función perseguir la verdad ${ }^{33}$, mientras una columna de The Washington Post se pregunta si corresponde a los moderadores hacer fact-checking en vivo ${ }^{34}$. Se suman, también, artículos que analizan los desempeños de los periodistas, como uno que alaba el estilo más

\footnotetext{
32 https:/ / www.npr.org/2015/11/07/455041830/maybe-journalists-dontbelong-at-presidential-debates

33 https://www.vox.com/policy-and-politics/2016/10/19/13317532/thirdpresidential-debate-moderator-chris-wallace 34 https://www.washingtonpost.com/news/the-fix/wp/2016/09/23/to-factcheck-or-not-to-fact-check-that-is-the-moderatorsquestion/?noredirect $=$ on\&utm_term $=.04 \mathrm{c} 70 \mathrm{e} 74 \mathrm{ee} 68$
} 
agresivo de dos de ellos ${ }^{35}$ y otro que crítica el estilo pasivo de un moderador ${ }^{36}$.

En todos los casos, son miradas impresionistas y de escaso sustento teórico, pero con una vocación normativa. A la vez, en el ámbito de la investigación académica, los trabajos que se han hecho sobre la participación de los periodistas en debates presidenciales son escasos y acotados, no hay un modelo sistemático para su estudio, a diferencia, por ejemplo, de lo que ha hecho Benoit (ej. 2001) para establecer un análisis funcional replicable de las respuestas de los candidatos en debates televisados en diferentes países y momentos.

Los estudios sobre periodistas y su labor en los debates se concentran en la agenda de los entrevistadores, que se deja ver a través de las preguntas, comparándola con la de los ciudadanos en debates de plaza pública (ej. Turcotte, 2015; Stromer-Galley y Bryant, 2011; Benoit y Hansen, 2001). Los trabajos son descriptivos respecto a los temas, las coincidencias y discrepancias entre ambas agendas, poniendo la función periodística como una alerta a considerar y no como un resultado empírico de la misma investigación. El mismo Turcotte (2015) deja ver la ausencia de investigación respecto a formatos o a lo que influencia esas agendas, versus una bibliografía más amplia que se interesa en la retórica, donde hay trabajos de referencia como el de Matera y Salwen (1996).

Este capítulo responde a la inquietud que plantean los analistas, cómo al desafío aún pendiente que sugieren las investigaciones previas, para proponer un modelo que permita sistematizar y replicar el estudio sobre el rol que ejercen los periodistas en debates presidenciales, ya sea como panelistas o moderadores. A la vez, abre la discusión de si se puede asumir un rol periodístico ideal en un debate y así contribuir, desde la investigación, al desarrollo de debates presidenciales,

\footnotetext{
${ }^{35}$ https://www.cjr.org/covering_the_election/martha_raddatz_anderson_coop er_debate_moderator_trump.php?facebook\&utm_content=buffer26f1 f\&utm_ medium $=$ social\&utm_source $=$ facebook.com\&utm_campaign $=$ buffer ${ }^{36}$ https://www.politico.com/story/2016/09/lester-holt-debate-clinton-trump228751?cmpid=sf\#ixzz4LQUCXPKy
} 
considerando que ese "deber ser" hasta ahora está contenido sólo en un terreno de lo testimonial y la opinión.

Para eso, ha sido fundamental el avance que ha tenido el estudio sobre roles periodísticos, explicados por Haniztch y Vos (2017) como la manera en que se desarrolla la identidad y la función institucional que cumplen los periodistas dentro de la sociedad. La propuesta es enmarcar una agenda de investigación dentro de esa línea, específicamente de role performance o ejecución, que permita evaluar la relación que el periodista establece con el poder y con la ciudadanía (Mellado, Hellmueller y Donsbach, 2017) con una herramienta que entregue evidencia para sustentar la discusión sobre la participación de los periodistas en los debates.

A continuación, se construyen de forma teórica cuatro roles, a partir de lo que ha aportado la investigación previa sobre campañas presidenciales y debates como también de roles periodísticos, cada uno tiene un vínculo particular con el quehacer del periodista dentro del sistema democrático como de su desempeño en el periodo de campaña.

Es posible que existan otros roles a identificar y que los mismos indicadores que componen los aquí propuestos se puedan combinar presentando nuevos roles, sin embargo, para comenzar una agenda de investigación al respecto, estos cuatro se hacen cargo de las preocupaciones planteadas por analistas e investigadores, son aplicables a diferentes países y permiten avanzar en la identificación de los roles que se han ejercido y en cómo debiesen ejercerse. Por lo mismo, se agregó un rol normativo o ideal de un periodista cívico a los que se agregan un rol de perro guardián, custodio de la verdad, y dos roles cuyas características se han advertido previamente en cobertura de campañas y debates, un periodista estratégico y un periodista adversario.

\section{Cívico}

El debate ofrece un espacio público en que los candidatos pueden compartir ideas, lo que es una muestra de una democracia sana y legítima (Coleman, 2000), por ende, es un acto cívico no oficial, siendo 
a la vez un producto periodístico si hay entrevistadores. Lo anterior justifica discutir la posibilidad de un rol normativo o ideal para estos profesionales cuando participan en los debates. Si bien se consideraron para esta discusión los indicadores del rol cívico propuesto por Mellado (2015), es demasiado amplio para las necesidades de esta investigación, por lo que se construyó un rol específicamente para su aplicación en el estudio de debates presidenciales.

En un rol cívico, se entiende como un periodista que es capaz de asumir la diversidad del público, sus miradas y necesidades (Jamieson y Waldman, 2003), lo que se ve exacerbado en un debate que está dirigido a una audiencia nacional. Eso significa un desafío, ya que los periodistas tendrían en ese contexto lo que Brants y Haan (2010: 416) llaman una "responsabilidad cívica", que al buscar representar a la audiencia, en este caso mediando entre el votante y los candidatos, se aleja de valores noticiosos tradicionales como los identificados por Galtung y Ruge (1965), que son causantes de que los periodistas busquen el conflicto y el atractivo comercial de una historia, como el mismo Galtung explicó en una entrevista a The Guardian, en $2019^{37}$.

Ese proceso, en primer lugar, exige a los periodistas estar al tanto de las preocupaciones y necesidades de la audiencia, escuchándolos (Coleman y Ross, 2010), para representarlas frente a la autoridad (Jamieson y Waldman, 2003). Coleman y Ross (2010: 129) llegaron a cuatro ideas que sintetizan la misión de un periodista en democracia, que son aplicable a esta propuesta. La primera tiene que ver con que la audiencia cuente con elementos para observarse a sí misma; la segunda, que puedan hacer sentido de los demás; la tercera es la más relevante para este capítulo y por eso la transcribo literal: "monitorear, facilitar, y conectar la deliberación pública, con asuntos de interés y preocupación común"; y la cuarta, es que los ciudadanos puedan entender los mecanismos con los que opera el poder y así exigir una rendición de cuentas a quienes están en una posición de poder.

Eveland, McLeod y Nathanson (1994) argumentan que una pregunta emitida en un debate televisado debe revelar la posición de los

\footnotetext{
${ }^{37}$ https://www.theguardian.com/world/2019/jan/18/johan-galtung-newsprinciples-journalists-too-negative
} 
candidatos sobre los temas en cuestión, para ayudar al votante a decidir su apoyo. En 2011, Stromer-Galley y Bryant, intentaron describir las características de lo que hace a una buena pregunta en un debate y concluyeron que su cualidad se basa en conducir a una respuesta que el candidato no pueda evadir, por lo que serían de mejor calidad las preguntas que se concentran en un solo tema, que además sea de preocupación pública.

Para aportar sentido, el periodista ha de entregar contexto a las temáticas que se plantean en los programas de los candidatos y a nuevos temas que pudiesen llegar a afectar a los votantes. Deja de ser un mero transmisor de datos, sino que explica y facilita la comprensión (Lehrer, 2011). Es también un intérprete, Haniztch y Vos (2017) hablan de un rol mediador y de un rol de educador, mientras que Mellado (2015) cuando habla del rol cívico, se refiere a un periodista que educa a los votantes en sus derechos y deberes.

Es el periodista en su capacidad de organizar el discurso quien tiene las herramientas para que el debate tenga ecuanimidad entre los candidatos y que sea impredecible para ellos, ambos elementos en los que coincide la literatura como la misión de un debate televisado (ej. Benoit y Hansen, 2004; Minow y Lamay, 2008; Morello, 2005).

Lo pueden conseguir facilitando la comparación entre candidatos y la clarificación de posiciones tanto en los temas de sus programas, como en temas que exijan una respuesta espontánea, porque los candidatos los han evitado o no los han contemplado en su agenda.

\section{Watchdog o perro guardián}

Este rol es complementario al cívico y es posible que estén combinados, sin embargo, se proponen como roles diferenciados, con el fin de identificar roles puros. El watchdog emerge de forma visible tras la investigación de Watergate, realizada por Bob Woodward y Carl Bernstein, ya que expuso la capacidad que tiene el periodismo con sus herramientas investigativas para influir en la realidad política al ser capaz de derrocar a un presidente, lo que contribuyó a la mítica noción de cuarto poder o como lo llama Norris (2014), cuarto Estado. 
Hay abundante literatura sobre el rol periodístico del watchdog de la democracia, por lo tanto, se consideraron los componentes que permitan identificarlo en la instancia de un debate presidencial televisado.

Se consideran propias del watchdog las acciones periodísticas que tienen como objetivo cumplir con la responsabilidad de proteger el interés público (Dumitru et. al., 2011). Iyengar (2011) explica que el rol de perro guardián es una tarea delegada de los ciudadanos a los periodistas, debido a las herramientas profesionales que tienen los reporteros. Acá hay un punto diferenciador respecto a un rol cívico para el análisis de los debates presidenciales. Mientras en un rol cívico el periodista le enseña al ciudadano a ser escéptico y es un representante de sus preocupaciones, en el rol de perro guardián, el periodista ejerce el escepticismo a través de preguntas, contra preguntas y datos, que dan cuenta de su investigación.

El periodista puede prevenir potenciales abusos y exponer los que los aspirantes hubiesen cometido (Jamieson y Waldman, 2003) exigiéndoles una rendición de cuentas. Es una actividad preventiva para alertar a la audiencia en caso de que alguno de los candidatos pudiese poner en riesgo al país o a sus habitantes, además de ayudar al votante a evaluar si los contendores tienen las cualidades profesionales y personales para dirigir un gobierno. Para ello, los periodistas son los custodios de los datos y pueden llevar a cabo un proceso de fact-checking o verificación de estos (Graves, 2016).

Es un escepticismo fundado en información, a partir de cómo los candidatos han enfrentado problemas previos, qué promesas han hecho si han estado en cargos públicos y cuál ha sido su desempeño en los papeles que ejercieron antes de la candidatura (Jamieson, 1992) o si han estado involucrados en procesos judiciales (Mellado, 2015).

\section{Estratégico}

Lo estratégico no se ha considerado en el estudio previo que se ha hecho sobre roles periodísticos, aun cuando es parte distintiva de la 
performance de los periodistas durante el proceso de campaña electoral y en la cobertura de temas políticos. Se le ha estudiado como un marco o frame, no obstante, sus características como han sido identificadas por Aalberg, Strömbäck y De Vreese (2012) son propias de una manera de ejercer el periodismo que se ajusta a la definición de rol en cuánto a su identidad y representación en la sociedad, porque son consecuencia de las prácticas y rutinas periodísticas.

Los autores describen dos maneras en las que se manifiesta el actuar estratégico de los periodistas al cubrir política, especialmente en el caso de las elecciones, presentan la campaña como si fuese una carrera de caballos, donde lo que importa son los potenciales ganadores y perdedores, lo que pone atención a las rivalidades entre los políticos. La segunda forma, consiste en leer las acciones de los políticos como si todas estuviesen basadas en estrategias políticas para ganar la elección. Por esta aproximación los periodistas enfocan su cobertura en esos aspectos de metapolítica, lo que deja de lado temas que son de interés ciudadano (Dimitrova y Kostadinova, 2013).

Según Iyengar (2011), esto ocurre porque los periodistas se encuentran bajo dos influencias durante la cobertura de una campaña: las fuerzas del mercado de los medios, que los llevan a buscar conflictos atractivos, lo que se contrapone a la propuesta cívica ideal; y los procesos organizacionales, normas y rutinas propias de la práctica periodística. Con esto en consideración, por mucho que el debate se trate de un evento particular, no por eso los periodistas no estarán exentos de poner en práctica lo que han hecho durante la cobertura de la campaña.

La primera forma, que corresponde a la carrera de caballos, lo que hace es aterrizar a algo concreto como un ganador y un perdedor las abstracciones de la realidad que ofrece una campaña presidencial (Jamieson, 1992). En ese sentido, es una mirada que se ampara en los datos de encuestas (Kraus, 2000). Eso da a los periodistas una ilusión de objetividad, respecto a quién dar mayor cobertura y cómo determinar el relato de cada candidato y la forma de abordarlos al momento de entrevistarlos. Esto último es de suma importancia cuando se estudian debates de países donde no hay un límite de candidatos participantes, ya que puede influenciar la forma en que 
serán tratados algunos candidatos que son potenciales ganadores o perdedores frente a sus pares en una misma instancia, lo que podría aumentar o mermar su legitimidad como aspirantes.

La dependencia de las encuestas son un problema para el periodismo, como lo han mostrado situaciones tales como el Brexit o la elección de Estados Unidos en 2016, como bien lo explicaba ya en 1996 Herbst, porque son una herramienta para simplificar lo que el público piensa, lo que ayuda a los reporteros a construir un relato coherente, pero no siempre fidedigno. Esto puede conducir a que las elecciones adquieran una dinámica de mercado, donde los votantes cotizan a los candidatos como si fuesen productos, un ejemplo de esto llevado a los debates presidenciales es la elección de 1996 en Nueva Zelanda, en la que se implementó una especie de gusano que subía o bajaba en pantalla según la evaluación en vivo que hacían las audiencias del desempeño de los candidatos en el debate (Clark, 2000).

Esta cobertura de competición influenciada por rutinas periodísticas que dependen del ejercicio de enfrentar parte y contraparte, entendido como un periodismo de declaraciones o como lo llaman en Estados Unidos: he said/she said journalism ${ }^{38}$, propicia que los periodistas no sólo pregunten sobre las rivalidades entre los candidatos, sino que las intenten provocar. No es lo mismo que en un rol cívico, dónde se busca establecer diferencias respecto a un proyecto país, mirada valórica e ideológica o cómo se abordaría un determinado problema. Acá lo que importaría sería el conflicto perecible (Chafee y Dennis, 1979).

Diversos estudios han mostrado que cuando se presentan estas rivalidades, la cobertura de la prensa se suele centrar en quién va ganando la disputa (Jamieson, 1992; Benoit y Hansen, 2001). Lehrer (2011) entrevistó a candidatos a la presidencia de Estados Unidos que habían participado en debates presidenciales televisados, George H.W. Bush, Jimmy Carter y Gerald Ford, coincidieron en la misma comparación: la experiencia se parecía estar en una competencia deportiva.

${ }^{38}$ https://niemanreports.org/articles/challenging-he-said-she-said-journalism/ 
En la segunda dimensión del rol estratégico están las interacciones que contienen metacomunicación: por qué se dijo algo, por qué se hizo algo o por qué se refirió al otro de determinada manera. Las razones tras esos "por qué" pasan a importar más en la agenda de la prensa que lo efectivamente dicho o hecho (Cappella y Jamieson, 1996).

Paletz y Entman (1981) son críticos con este tipo de cobertura, porque según ellos tiene dos consecuencias negativas para un periodo de campaña, primero, la hace menos racional, dando realce a las estrategias y conflictos de los candidatos por sobre sus argumentos y cualidades; en segundo lugar, porque deshumaniza la elección, volviéndola cínica en cuánto a interpretar tanto cada acción de los candidatos como una estrategia electoral, que finalmente se pierde la confianza en el sistema y pone a las cualidades para ser presidente como un desafío imposible, porque no hay quién pueda cumplir con esas características.

\section{Antagonista o adversario}

Que un periodista sea un adversario de la autoridad, puede ser un aporte si su forma de abordar al candidato está fundada en los principios ya expuestos del perro guardián, por esa razón, cuando Mazzolenni (2010) escribe sobre el periodista adversario lo que hace es considerar ambas como una relación de antagonismo hacia el poder, pero distingue a un periodista que sólo busca antagonizar, versus uno que actúa en función de la rendición de cuentas. Al primero no le interesa defender al ciudadano, sino generar contenidos sensacionalistas que puedan producir nuevos titulares a partir de dicha interacción.

En esta propuesta se considera importante esa distinción, aunque como se mencionó, es fácil que estos roles se hibriden, porque el adversario es una deformación del watchdog (Jamieson y Waldman, 2003; Patterson, 1996), con la diferencia de que este ladra y muerde sin proteger. Patterson (1996: 103) denomina a esta aproximación de los periodistas a las fuentes como "periodismo de ataque", espacio en que dialoga con el rol estratégico, ya que en ambos casos el periodista se plantea ante la política desde la desconfianza, lo que como comentamos puede generar una desconfianza mayor en el sistema 
democrático (Cappella y Jamieson, 1996). Lo que justifica en esta discusión la inclusión de un rol cívico ideal, como contraparte a este.

El rol de adversario se explica por la profesionalización de la comunicación política, en que los periodistas ven amenazada su independencia frente al discurso de los candidatos que pueden construir una relación con la audiencia sin la necesidad de la prensa (Brants y Voltmer, 2011), esto se exacerba con las prácticas de campaña postmoderna descritas por Norris (2000), en las cuales la tecnología permite a los candidatos tener sus propios espacios mediáticos en internet para impactar a su electorado. Beus (2011) lo resume como una disputa entre los periodistas y los políticos respecto a quién es un mejor representante de la audiencia. Así, al asumir un rol de adversario, el periodista se convierte en parte de la noticia, al ponerse en el mismo lugar que la fuente a la que enfrenta (McCall, 1980).

Esto conlleva a que los periodistas actúen en búsqueda del reconocimiento profesional de la audiencia y especialmente de sus colegas (Clayman, 2002). Un estilo agresivo al plantear las preguntas a los candidatos puede ser visto como una manifestación de "independencia y asertividad" por otros periodistas (Brants y Voltmer, 2011: 129). La misma instancia del debate presidencial televisado facilita que surja este rol, debido a que los periodistas tienen un mayor control sobre la agenda y el formato, y los candidatos intentarán imponer una propia llevando la conversación hacia los temas que les acomodan, circunstancia que conduce a los periodistas a ser más agresivos que en otras instancias de entrevista (Schroeder, 2016).

A lo anterior, se suma que el debate es una oportunidad extraordinaria para que un periodista demuestre su capacidad profesional. Como lo exponen Minow y Lamay (2008), un debate presidencial televisado es una audición en vivo ante todo el país para un entrevistador.

El antagonismo de los periodistas toma forma en los debates, a través de ataques con preguntas que contienen hostilidad explícita hacia los candidatos, concentrándose en sus debilidades de carácter y errores (Benoit y Hansen, 2001), usando la contra pregunta como un recurso para arrinconar al candidato (McCall, 1980), lo que sirve para 
identificar, según Brants y Voltmer (2011), la desconfianza desde el periodista hacia el aspirante, además de utilizar la ironía (Attardo, 2000; Nuolijarvi y Tiitula, 2011). En este rol, por lo tanto, los candidatos serán desafiados, exigiéndoles soluciones inmediatas antes que propuestas viables (Patterson, 1996).

\section{Conclusión}

El desarrollo de un debate presidencial en el que participan periodistas está sujeto a su desempeño, sean estos más o menos activos. Sin embargo, la discusión sobre su aporte no ha avanzado desde 1960 y su estudio aún es incipiente, lo que no permite obtener conclusiones fundantes respecto a su función para una democracia y los ciudadanos en dicha instancia.

$\mathrm{Su}$ aparición en los debates fue circunstancial, producto de la negociación y la Guerra Fría, y se instaló como una tradición con variaciones y mutaciones, pero en la que, como muestran los ejemplos de la elección presidencial de 2016 en Estados Unidos, se mantienen los mismos cuestionamientos que en el primer debate presidencial televisado de la historia en 1960.

Por lo tanto, se propone avanzar en su investigación en el marco del estudio de la performance de roles periodísticos, con un modelo inicial de cuatro roles, que acá fueron presentados en su construcción con diversas fuentes.

El autor ya ha desarrollado un trabajo experimental mostrando los indicadores y aplicándolos a estudios de caso, por ejemplo, en NúñezMussa (2018), que responden a la lógica del contexto electoral en que fueron estudiados, pero a la vez abren nuevas preguntas, respecto a qué influencia la aparición de estos roles, por ejemplo, la competencia entre los candidatos, su incumbencia, el canal de televisión al que pertenece el periodista o su estilo particular. También se han observado híbridos que combinan algunos de los indicadores planteados y aún hay desafíos 
metodológicos para hacer más objetiva la identificación de los indicadores al codificar para un análisis de contenido.

En este trabajo se comparte la construcción inicial de los roles, con el objetivo de que esta sea enriquecida y discutida, ya que también pudiese haber otros roles y posibilidades que no se están considerando o agregar indicadores que perfilen con más detalle a los acá planteados.

Se busca establecer un primer puente entre el estudio de roles periodísticos y su aplicación a los debates presidenciales, con la intención de que se podrá contar con mayor evidencia para la discusión permanente sobre cuál es y cómo debería ser ese periodista que enfrenta a un aspirante a una situación de poder ante a una audiencia y potencial electorado, captado por cámaras y transmitido de forma masiva.

\section{Bibliografía}

Aalberg, T., Strömbäck, J. y De Vreese, C. H. (2012). “The framing of politics as strategy and game: A review of concepts, operationalizations and key findings". Journalism, 13(2), 162-178.

Attardo, S. (2000). "Irony as relevant inappropriateness". Journal of Pragmatics, 32 (6), 793-826.

Benoit, W. (2001). The primary decision: a functional analysis of debates in presidential primaries. Santa Barbara: Praeger.

Benoit, W. y Hansen, G. (2001). "Presidential debate questions and the public agenda”. Communication Quarterly, 49(2), 130-141.

Benoit, W. y Hansen, G. (2004). "Issue ownership in primary and general presidential debates". Argumentation and advocacy, 49, 143154.

Brants, K. y Haan, Y. (2010). "Taking the public seriously: three models of responsiveness in media and journalism". Media, Culture and Society, 32(3), 411-428.

Brants, K. y Voltmer, K. (2011). "Introduction: Mediatization and decentralization of political communication". En Brants, K. y Voltmer, K. (eds.), Political Communication in Postmodern Democracy. Challenging the primacy of politics. New York: Palgrave Macmillan. 
Cappella, J. N. y Jamieson, K. H. (1996). "News frames, political cynicism, and media cynicism". The Annals of the American Academy of Political and Social Science, 546(1), 71-84.

Carter, R. F. (1962). "Some effect of the debates". The great debates. Indiana: Indiana University Press.

Chafee, S. y Dennis, J. (1979). "Presidential debates: an empirical assessment". En Ranney, A. (ed), The past and future of presidential debates. Washington DC: American Enterprise Institute for Public Policy Research.

Clark, H. (2000). "The worm that turned: New Zealand's 1996 general election and the televised 'worm' debates". En Coleman, S. (ed), Televised election debates. International perspectives. Great Britain: MacMillan Press.

Clayman, S.E. (2002). "Tribune of the people: maintaining the legitimacy of aggressive journalism". Media, Culture and Society, 24, 197-216.

Coleman, S. (2000). "Meaningful political debate in the age of the soundbite". En Coleman, S. (ed), Televised election debates. International perspectives. Great Britain: MacMillan Press.

Coleman, S. y Ross, K. (2010). The media and the public. "Them" and "Us" in media discourse. UK: Wiley Blackwell.

Dimitrova, D. V. y Kostadinova, P. (2013). "Identifying antecedents of the strategic game frame: A longitudinal analysis". Journalism \& Mass Communication Quarterly, 90(1), 75-88.

Dumitru, A., Danciu, B., Plaesu, A., Taranu, A. M. y Lazaroiu, G. (2011). "The role of the media in processes of democratization and consolidation". Economics, Management and Financial Markets, 6(2), 491.

Eveland, W. P., McLeod, D. M. y Nathanson, A. I. (1994). "Reporters vs. undecided voters: An analysis of the questions asked during the 1992 presidential debates". Communication Quarterly, 42, 4.

Galtung, J. y Ruge, M. (1965). "The structure of foreign news: the presentation of the Congo, Cuba and Cyprus crises in four Norwegian newspapers". Journal of International Peace Research, 1, 64-91.

Graves, L. (2016). Deciding what's true. The rise of political fact-checking in American Journalism. New York: Columbia University Press. 
Hanitzsch, T., y Vos, T. P. (2017). "Journalistic roles and the struggle over institutional identity: The discursive constitution of journalism". Communication Theory, 27(2), 115-135.

Herbst, S. (1996). "Public expression outside the mainstream". The Annals of the American Academy of Political and Social Science, 546, $22-$ 33.

Iyengar, S. (2011). Media politics: A citizen's guide $2^{\text {nd }}$ ed. New York: W.W. Norton.

Jamieson, K. (1992). Dirty politics. Deception, distraction, and democracy. New York: Oxford University Press.

Jamieson, K. y Waldman, P. (2003): The press effect. Politicians, journalists, and the stories that shape the political world. New York: Oxford University Press.

Kirkpatrick, E. (1979). 'Presidential candidate 'debates': What can we learn from 1960?”. En Ranney, A. (ed), The past and future of presidential debates. Washington DC: American Enterprise Institute for Public Policy Research.

Kraus, S. (1962). The great debates. Indiana: Indiana University Press.

Kraus, S. (2000). Televised presidential debates and public policy. New York: Routledge.

Lanoue, D. y J. Schrott, P.R. (1991). The joint press conference. The history, impact and prospects of American presidential debates. Westport: Greenwood Press.

Lehrer, J. (2011). Tension city. Inside the presidential debates, from KennedyNixon to Obama-McCain. New York: Random House.

Martel, M. (1983). Political campaign debates, images, strategies and tactics. New York: Longman.

Matera, F. y Salwen, M. (1996). "Unwieldy questions? Circuitous answers? Journalists as panelists in presidential election debates". Journal of Broadcasting and Electronic Media, 40, 309-317.

Mazzoleni, G. (2010). La Comunicacion Politica. Madrid: Alianza Editorial.

McCall, J. M. (1984). "The panelists as pseudo-debaters: An evaluation of the questions and questioners in the presidential debates of 1980". Journal of the American Forsenic Association, 21.

Mellado, C. (2015). "Professional roles in news content. Six dimensions of journalistic role performance". Journalism Studies, 16(4), 596614. 
Mellado, C., Hellmueller, L. y Donsbach, W. (2017). "Journalistic role performance. A new research agenda in a digital and global media environment". En Mellado, C., Hellmueller, L., y Donsbach, W. (eds), Journalistic roles performance: concepts, contexts and methods. New York: Routledge.

Mickelson, S. (1972). The electronic mirror. Politics in an age of television. New York: Dodd, Mead and Company.

Minow, N. N. y LaMay, C. L. (2008). Inside the presidential debates. Their improbable past and promising future. Chicago: The University of Chicago Press.

Morello, J. T. (2005). "Questioning the questions: an examination of the "unpredictable" 2004 Bush-Kerry town hall debate". Argumentation and advocacy, 41, 211-224.

Norris, P. (2000). A Virtuous Circle: Political Communications in PostIndustrial Societies. New York: Cambridge University Press.

Norris, P. (2014). "Watchdog journalism”. En Bovens, M., Goodin, E., y Schillemans, T. (eds.), The Oxford handbook of public accountability. Oxford: Oxford University Press.

Núñez-Mussa, E. (2018). "Variación y distribución de los roles periodísticos en los debates presidenciales televisados de Chile en 2005 y 2013". En Memorias XIV Congreso de la Asociación Latinoamericana de Investigadores de la Comunicación. Grupo Temático 16: Estudios sobre Periodismo. Costa Rica: Universidad de Costa Rica.

Nuolijärvi, P. y Tiittula, L. (2011). "Irony in political television debates". Journal of Pragmatics, 43(2), 572-587.

Paletz, D. L. y Entman, R. M. (1981). Media. Power. Politics. New York: The Free Press.

Patterson, T. E. (1996). "Bad news, bad governance". The Annals of the American Academy of Political and Social Science, 546, 22-33

Ruiz, F. J. y Alberro, H. (2012). "Ola de debates electorales en América Latina: Luces y sombras de un avance democratic". Konrad Adenauer Stiftung: Informe especial.

Sarnoff, R. W. (1962). "An NBC view". En Kraus, S. (ed.), The great debates. Indiana: Indiana University Press.

Schroeder, A. (2016). Presidential debates. Risky business on the campaign trail. New York: Columbia University Press. 
Seltz, H. A. y Yoakam, R. D. (1962). "Production diary of the debates". En Kraus, S. (ed.), The great debates. Indiana: Indiana University Press.

Stepp, C. S. (1987). "The role of journalist's questions in campaign forums". Political Communication and Persuasion, 4, 279-288.

Stromer-Galley, J. y Bryant, L. (2011). "Agenda control in the 2008 CNN/YouTube Debates". Communication Quarterly, 59(5), 529546.

Turcotte, J. (2015). “The news norms and values of presidential debate agendas: an analysis of format and moderator influence on question content". Mass Communication and Society, 18(3), 239-258. 


\title{
Agenda mediática y política: ¿Amistades peligrosas? Un análisis desde el fact-checking
}

\author{
José Rúas-Araújo \\ Universidade de Vigo \\ Andrés Mazaira Castro \\ Universidade de Vigo
}

PARA CITAR: Rúas-Araújo, J. y Mazaira-Castro, A. (2019). “Agenda mediática y política: ¿Amistades peligrosas? Un análisis desde el factchecking”. En Conde-Vázquez, E., Fontenla-Pedreira, J. y Rúas-Araújo, J. (Eds.), Debates electorales televisados: del antes al después (pp. 149-169). Cuadernos Artesanos de Comunicación, cac154. La Laguna (Tenerife): Latina. DOI: $10.4185 / \operatorname{cac} 154$.

\section{Resumen}

El objetivo de este trabajo es analizar las declaraciones de los candidatos que intervinieron en los debates electorales televisados celebrados con motivo de la convocatoria de elecciones generales en España en 2015 y 2016 y observar en qué medida se corresponden con titulares y noticias difundidas por la prensa, durante la precampaña electoral, con el propósito de comprobar la coincidencia entre las agendas, mediática y política.

Los resultados muestran una coincidencia entre ambas agendas que se sitúa en torno al 50\%, en los debates entre dos contendientes, y con porcentajes muy por encima $(73,63 \%)$, en el caso de los debates entre cuatro candidatos. 
La conclusión es que se produce un claro alineamiento y ensamblaje mediático y político, constatando que la prensa sigue siendo una fuente de referencia para los candidatos que intervienen durante la campaña electoral en los debates televisados.

Palabras clave: Debates televisados, campaña electoral, agenda, medios, prensa, televisión, fact-checking.

\section{Periodismo en crisis: distintas percepciones}

T A actual situación de crisis de credibilidad de las instituciones, que Limplica también a los medios de comunicación, plantea un debate sobre si la solución a los problemas que afectan al periodismo está dentro o fuera del periodismo.

La desconfianza de los ciudadanos hacia los medios llega hasta el punto de cuestionar que quienes tienen la capacidad de dirigir -y en consecuencia manipular- a la opinión pública, se conviertan ahora en cruzados contra las noticias falsas y defensores de la verdad.

La mayor evidencia al respecto la aportó -cómo no- el propio presidente de los USA, Donald Trump, cuando se negó a responder a un periodista de la $C N N$, diciendo "You are Fake News", tal y como recuerda Brian McNair (2018), con la intención no sólo de abrir un debate sobre qué es la verdad, sino también cuál debe ser el rol del periodista en la democracia actual, bajo el entendimiento de que las fake news no son la enfermedad, sino el síntoma (López-Borrull, 2018), la expresión de una crisis más amplia de las élites, dentro de las cuales los ciudadanos también incluyen a la prensa (Rúas, Mazaira, Rodríguez, 2018).

Un contexto adverso marcado tanto por el desprestigio de las élites y los medios de comunicación, como por la crisis de su modelo de negocio, la ruptura del ciclo de producción de noticias que permitía su verificación (López-Borrull, Vivés-Grácia y Badell, 2019) y la creciente tendencia a informarse a través de las redes sociales, mucho antes que 
a través de los medios de comunicación tradicionales (Shearer y Gottfried, 2017).

La discusión sobre la respuesta del periodismo se mueve en dos direcciones. Por un lado, están quienes plantean que el periodismo debe defender su profesión, dejando de apelar a su imparcialidad y neutralidad a la hora de abordar las noticias falsas, y adoptando una posición activa para hacer frente a una retórica anti-medios que incluso llegó a percibirse como una teoría de la conspiración, en la que los periodistas son vistos como actores partidistas que escriben intencionadamente de forma engañosa (Pingree, Whatson, Sui et al., 2018).

Esta corriente defiende como adecuada la mirada del periodismo sobre sí mismo y asegura que los efectos de la verificación de hechos serán más positivos con la defensa del periodismo que sin ella. Una posición y respuesta activa acorde con los estudios que indican que, en muchos casos, la confianza de los medios por parte del público está determinada por lo que otros dicen acerca de los medios de comunicación y no tanto por una observación directa del contenido de las noticias (Ladd, 2012).

Pero por otra parte, en la dirección contraria, están quienes apuntan que los periodistas no pueden solucionar los problemas del periodismo (Ornebring, 2018), al considerar que depende de otras cuestiones como son el estatus socioeconómico -los buscadores de noticias tienden a tener mayores ingresos y nivel educativo que los evitadores o indiferentes (Ksiazek et al., 2010)- cuyas diferencias se acentúan a nivel mundial entre las distintas naciones, provocando una brecha cada vez mayor en el conocimiento. Un problema que también depende de la educación y los recursos cognitivos de la audiencia, de forma que a mayor educación, menor impacto de la desinformación y menos fragmentación y polarización de las audiencias.

Todo ello agravado por el problema general de los modelos de negocio fallidos en la prensa, las economías débiles de muchos países y los mercados y anunciantes en apuros, que provocan que los medios de comunicación se vuelvan especialmente vulnerables a los intereses 
políticos y prácticas poco éticas, de forma que el nexo entre democracia y periodismo, asumido bajo la ortodoxia liberal, resulta problemático (Wasserman, 2019).

De ahí quienes también defienden lo que antes se denominaba "News Literacy", la lectura crítica de los medios, centrada antes en distinguir, claramente, la información y los hechos de las opiniones, pero que en la actualidad requiere un enfoque más complejo, para saber si lo que se describe como un hecho en realidad lo es.

Como también se observa la necesidad de una alfabetización digital, señalando el papel de la escuela y la universidad como un punto clave para la recuperación de la confianza en la prensa, y ante la necesidad de abandonar ambos su tendencia centrípeta (Nigro, 2018). De hecho, la propia Unesco ha considerado la Alfabetización Mediática e Informacional / Media and Information Literacy (AMI/MIL) ${ }^{39}$, como uno de sus principales compromisos, con la intención de promover sistemas de información libres, independientes y pluralistas.

Distintos enfoques ante una crisis del periodismo que también se ha calificado como epistémica (Steen, 2019) y ante la cual a los periodistas les resulta difícil "ir más allá de su epistemología establecida" (Lewis y Westlund, 2015: 452) y que encuentra su salida en la alfabetización informacional, a través de una actitud más constructivista, también por parte de los propios periodistas.

La falta de credibilidad y confianza en la información supone un reto para el periodismo, además de coartar la formación de una opinión libre e informada e impedir el ejercicio de un auténtico debate y la discusión pública.

En el caso de España, el CIS muestra en sus últimos Barómetros de septiembre $(3223)^{40}$ y diciembre $(3234)^{41}$ de 2018 , la notable pérdida

\footnotetext{
${ }^{39} \mathrm{http}: / /$ www.unesco.org/new/es/communication-and-information/mediadevelopment/media-literacy/mil-as-composite-concept/

${ }^{40}$ http://datos.cis.es/pdf/Es3223mar_A.pdf

${ }^{41}$ http://www.cis.es/cis/opencms/ES/NoticiasNovedades/InfoCIS/2019/Do cumentacion_3234.html
} 
de confianza de los españoles en sus instituciones políticas, con un $53,5 \%$ de los encuestados que se declaran insatisfechos con la labor del Congreso de los Diputados y un 75,9\% que declaran que el Parlamento estatal presta demasiada atención a problemas de poca importancia para los españoles.

Paralelamente, el último informe del Edelman Trust Barometer 2019 $9^{42}$, apunta a la falta de confianza de los ciudadanos en los medios como fuentes de noticias e información, a lo que se suma el hecho de que España es uno de los países del mundo más preocupados por la difusión de noticias falsas, situación que preocupa en el caso de 7 de cada diez ciudadanos del mundo, pero que en el caso de nuestro país alcanza al 80\% de los encuestados, toda vez que el 63\% de las personas reconocen que no saben cómo distinguir el buen periodismo de los rumores o las mentiras.

Asimismo, el Barómetro Europeo (464) sobre "Noticias falsas y desinformación on line" realizado en 2018 , muestra que un $78 \%$ de españoles considera que está expuesto a noticias falsas al menos una vez a la semana y un 53\% indica que todos o casi todos los días. Además, hay una clara percepción de que estas noticias falsas pueden tener efectos perjudiciales para la democracia (High-Level Expert Group on Fake news and Disinformation, 2018; European Comission, 2018).

Una deslegitimación de las instituciones y falta de credibilidad en la información recibida que, en el caso de España, afecta a casi 7 de cada 10 ciudadanos encuestados $(68,1 \%)$, tal y como se indica en alguno de los estudios más recientes (Gualda y Rúas, 2019).

La contaminación de la información con la difusión de noticias falsas, además de tener fuertes implicaciones y consecuencias democráticas (Wardle y Derakhshan, 2017), también puede llegar a desplazar la agenda pública y ser utilizada como pretexto para atacar, restringir o burlar la prensa libre.

\footnotetext{
${ }^{42}$ https://www.edelman.com/sites/g/files/aatuss191/files/2019-

01/2019_Edelman_Trust_Barometer_Global_Report.pdf
} 
Las noticias falsas imitan el periodismo real, devalúan y deslegitiman las voces expertas, socaban la confianza y cobertura seria de los medios, se propagan a través de las redes sociales de forma más rápida y profunda que la verdad y, además, se han convertido en una actividad lucrativa (Sadiku et al., 2018).

La práctica de verificar antes de publicar comenzó a erosionarse con la llegada de la televisión por cable, los ciclos de noticias de 24 horas y la adopción generalizada de las redes sociales (especialmente durante los eventos y situaciones de crisis), en lo que se ha denominado como la era de las noticias hiperconectadas (Nicolaisen, 2013; Kovach y Rosenstiel, 2017 a y b).

Todo ello sumado al hecho de que la desinformación y los rumores se han convertido en algo habitual en los medios digitales, resultando muy difícil la difusión de información compensatoria a un ritmo similar (Zubiaga et al., 2016), como consecuencia del creciente proceso de automatización y segmentación algorítmica, que influyen en la producción y el ciclo de vida de las noticias rápidas y el intercambio de información, dentro de la denominada economía de la atención (Ciampaglia, Flammini y Menczer, 2015), comprometiendo la capacidad de nuestras sociedades para formar opiniones libres e informadas.

La competencia económica por la atención, la presión sobre los ritmos de producción a la que se enfrentan muchos periodistas para cumplir con plazos urgentes o publicar alertas y actualizaciones rápidamente, en tan sólo 15 minutos, puede hacer de la verificación de hechos (factchecking) una labor extremadamente difícil (Patel, 2017).

En cualquier caso, a pesar de las dificultades, cada vez mayores, para acreditar la credibilidad de las fuentes, los periodistas siguen luchando por adaptarse a las nuevas condiciones y desempeñando un papel destacado a la hora de ayudar a corregir la información errónea en las redes sociales, desempeñando un papel más rápido y activo a la hora de confirmar o negar un rumor, en comparación con el resto de usuarios (Zubiaga et al., 2016). 
Cada vez más organizaciones y medios de comunicación se están sumando a la comprobación y verificación de datos y hechos políticos. A la cabeza se encuentran Politifact (www.politifact.com), vinculado al Instituto Poynter; Factcheck (www.factcheck.org) y el servicio de factckecking de The Washington Post

(www.washingtonpost.como/news/fact-checker), seguidos de otras plataformas como Stop Fake, destinado a desmentir las falacias de la propaganda rusa y que ya cuenta con una versión en español (www.stopfake.org/es/portada), además de Snopes

(www.snopes.com), centrada en la comprobación de rumores y leyendas urbanas o Full Fact (https://fullfact.org), organización benéfica con sede en Londres.

A nivel internacional, destaca también el Global Investigative Journalism Network (www.gijn.org), iniciativa en la que colaboran múltiples países, incluida la Fundación Ciudadana Civio, en el caso de España (www.civio.es).

A mediados de 2018, se estimaba que había un total de 148 equipos dedicados a labores de fact-checking en todo el mundo, de las cuales apenas una tercera parte habían suscrito el código de principios, entre ellas, en España, el programa de televisión "El Objetivo", de La Sexta, y la cuenta "Maldito Bulo" (www.maldita.es/malditobulo), ambos dedicados a labores de fact-checking (Magallón-Rosa, 2018). Asimismo, en el caso de España, contamos con ejemplos como el del periódico El País, que dispone de una sección online denominada "Hechos".

El reciente descubrimiento de la red bautizada como "Kumanovo", en Macedonia del Norte, puso de manifiesto la intención de distribuir contenidos falsos con la única intención de obtener ingresos por publicidad, a través de una serie de sitios conectados a la red publicitaria Google AdSense.

Precisamente, en Macedonia se encuentra la fundación Metamorphosis para Internet y la Sociedad (http://metamorphosis.org.mk/en), cuyo objetivo es capacitar a los ciudadanos para responsabilizar a los medios y ayudar a los periodistas en la implementación de sus estándares 
profesionales, a través de un equipo que proporciona herramientas y recursos en línea para la educación pública y la sensibilización. El equipo analiza artículos diarios de distinta procedencia y géneros informativos, de acuerdo con una serie de parámetros de veracidad (presencia, exactitud y fiabilidad de los hechos), tipo de fuentes (relevancia, número, pluralismo), amplitud, claridad y comprensión de la información, imparcialidad, presencia de comentarios, originalidad (posibles contenidos plagiados), calidad del titular, fotografía con atribución de autoría, presencia de discurso del odio o incitación a la violencia $y$, finalmente, calidad y legibilidad de la web. Todo ello combinado con un análisis crítico del discurso, realizado por otro grupo de analistas y expertos en derechos humanos.

En líneas generales, lo cierto es que toda operación urgente de verificación digital de noticias, pasa por las “W's" y preguntas clásicas del periodismo, tal y como recuerda Redondo (2018): QUIÉN (lo cuenta y firma), QUÉ (profundizar en el contenido de lo que dice), CUÁNDO (fecha y zona horaria, si es una publicación antigua), DÓNDE (referencias y contexto del lugar), CÓMO (es una información u opinión, una difusión masiva y repentina, de cuentas recién abiertas o con escasa actividad previa) y POR QUÉ (si hay motivos ocultos tras la difusión de esa información o es una crítica contra alguna persona, colectivo o institución).

Aun así, nos enfrentamos a una segunda generación de fake news, con empresas de tecnología y software que desarrollan herramientas sofisticadas para manipular grabaciones de audio y video, provocando que personas reales digan cosas que nunca han dicho (Diakopoulos, 2018), y utilizando para ello su propia imagen. Una manipulación contra la que empiezan a surgir nuevas herramientas (como Face Forensis $^{43}$, un programa de análisis y reconocimiento facial), pero que, una vez más, demuestra la desproporción existente entre la masiva propagación de informaciones falsas y los escasos recursos, rapidez y eficacia para combatirlas.

${ }^{43} \mathrm{http}: / /$ www.faceforensics.com/ 


\section{Campañas, debates electorales y agenda temática}

El número de personas que leen noticias falsas durante los procesos electorales creyendo que son verdaderas sigue creciendo (Guess et al., 2018). El tradicional control y verificación de hechos llevado a cabo con motivo de cada convocatoria electoral norteamericana (Wintersieck, 2017) y que cuenta también con experiencias en varios países europeos (Graves y Cherubini, 2016), cobró mayor interés, como ya se indicó, a raíz de las recientes presidenciales con el candidato republicano Donald Trump y sus bulos y falsedades, denunciados por la prensa.

El fact-checking se ha convertido, en la actualidad, en un reclamo y un servicio en los cibermedios (López, Rodríguez-Vázquez, ÁlvarezGromaz, 2016).

La propia Comisión Europea, ante la próxima convocatoria de elecciones en el mes de mayo y como consecuencia de los continuos ataques recibidos en los procesos electorales de varios países, realizó una serie de recomendaciones "en defensa de unas elecciones europeas libres y justas", planteadas en su reunión del Salzburgo (COM, 2018, documento 637). En el mismo contexto, la ONU y OSCE plantearon una "Declaración Conjunta sobre Libertad de Expresión, Fake News, Desinformación y Propaganda". Todo ello con la intención de desarrollar una cultura de seguridad en la sociedad e incrementar la sensibilización y alfabetización digital, en la línea de los objetivos planteados por la Agencia Europea de Seguridad de las Redes y de la Información (ENISA).

La utilización por gobiernos y parlamentos de declaraciones falsas o exageradas, de forma estratégica, con la intención de crear desconfianza o cuestionar a los adversarios -incluso a través de argumentos y críticas ad hominem- no es nueva y ha sido estudiada, desde el punto de vista de análisis de la argumentación (Walton, 2005) y los discursos de los actores implicados, utilizando, en la actualidad, las posibilidades que ofrece el análisis semántico y las nuevas tecnologías a través, por ejemplo, de herramientas y el análisis de 
declaraciones de políticos volcadas en portales como PolitiFact (Yang Wang, 2017).

Patwari et al. (2017) utilizaron debates en elecciones primarias y presidenciales americanas para analizar el valor de las declaraciones realizadas por los candidatos y otros investigadores como Naderi y Hirst (2018), aplicaron el fact-checking y la comprobación de declaraciones en los debates parlamentarios en Canadá.

Existen también algunas experiencias de fact-checking parlamentario realizadas en España, concretamente en el caso del Parlamento de Galicia, de análisis de las preguntas y respuestas orales en pleno por parte del presidente de la Xunta de Galicia y los portavoces de la oposición (Rúas, Mazaira y Puentes, 2017), que muestran cierto grado de exactitud y veracidad $(65 \%)$ de los datos aportados en sus intervenciones. Sin embargo, en este estudio también se constata que los parlamentarios no citan las fuentes, que la transparencia y accesibilidad a los datos proporcionados es relativa y su utilización puramente retórica, sin darle mayor transcendencia ni fomentar el debate y la discusión pública.

\subsection{Agenda mediática y política}

Los debates electorales son un proceso que nos permite observar cuáles son los temas en las agendas y temas de campaña de los medios, los políticos y los ciudadanos y la intersección y correlación temática entre las mismas, siguiendo las teorías de la agenda-setting (McCombs y Shaw, 1972).

El énfasis que los medios ponen sobre los temas en la cobertura de una campaña influye sobre la selección, priorización, enfoque y encuadre, de acuerdo con las teorías del priming (Iyengar y Kinder, 1987) y framing (Reese, Gandy y Grant, 2001).

El análisis de los debates debate nos permite abordar de forma conjunta tanto la agenda mediática, como la agenda política y analizar el posible impacto de ambas en los ciudadanos, teniendo en cuenta, con respecto a la primera, la jerarquización de los medios en el 
establecimiento de los temas, primero por la prensa, coincidiendo habitualmente en la fase de precampaña y, seguidamente, por la televisión, en la "enfatización” de los mismos (López, Puentes y Rúas, 2017).

Tomando como referencia el concepto de relevancia (Weaver, 1991), podemos contrastar en las agendas los asuntos de relevancia mediática, política y ciudadana, con la intención de encontrar alguna intersección, dentro de la denominada área de impacto de la comunicación política (Bouza, 2004).

Un área de impacto en la que, en muchas ocasiones, se produce un ensamblaje entre las agendas de los medios y los políticos, dejando incluso al margen a los ciudadanos y, en consecuencia, las posibilidades de diálogo y conversación, tradicional y a través de las redes sociales, en la carrera (horse-race) y recta final de la campaña electoral (López, Oñate y Chavero, 2018).

Precisamente, en este trabajo mostramos el ensamblaje mediático y político existente, entre los temas marcados por la prensa y los expuestos, posteriormente, por los candidatos que participaron en los dos debates electorales televisados analizados.

\section{Metodología}

El objetivo de este trabajo es analizar las declaraciones de los candidatos que intervinieron en los debates electorales televisados celebrados con motivo de la convocatoria de elecciones generales en España en el año 2015 y 2016 y observar en qué medida se corresponden con titulares y noticias difundidas por la prensa, durante la precampaña electoral, con el propósito de comprobar la coincidencia entre las agendas, mediática y política.

Para analizar la coincidencia entre las agendas de los medios y los argumentos utilizados por los participantes en los debates electorales, hemos analizado las intervenciones de dichos participantes en los bloques y ámbitos de 1. Economía y Empleo y 2. Estado del Bienestar, que contenían datos susceptibles de ser contrastados, tanto en el debate 
a dos de las elecciones generales del año 2015 (debate entre el candidato del PSOE, Pedro Sánchez, y el candidato del PP, Mariano Rajoy, celebrado el 14 de diciembre de 2015) como en el debate a cuatro celebrado con motivo de las elecciones generales de 2016 (entre el candidato de Podemos, Pablo Iglesias;el candidato del PSOE, Pedro Sánchez; el candidato de Ciudadanos, Albert Rivera, y Soraya Sáenz de Santamaría, por el PP).

En concreto, observamos en qué medida los temas señalados por los intervinientes coincidían con noticias publicadas en la versión online de los medios impresos y digitales, a través del buscador de Google, en el apartado de noticias, y tomando como criterio el hecho de que sus intervenciones registraran al menos tres entradas destacables y, en la mayoría de los casos, coincidentes con las noticias publicadas por varios medios. Esta comprobación nos sirvió para descubrir, igualmente, cuáles fueron las fuentes y medios a los que recurrió cada candidato.

\section{Resultados}

Tal y como se puede observar en la tabla 1, la coincidencia entre los datos indicados por el candidato del PP, Mariano Rajoy, alineación entre el tratamiento dado por Mariano Rajoy a los datos y los contenidos publicados en los medios supera en casi 15 puntos la convergencia alcanzada por pedro Sánchez en sus intervenciones, en los bloques del debate correspondientes a los temas de Economía y Estado del Bienestar.

Tabla 1. Nivel de coincidencia entre las intervenciones de los participantes en el debate de 2015 y las agendas de los medios en el trimestre anterior al debate

\begin{tabular}{|l|c|c|c|}
\hline & $\begin{array}{c}\text { Intervenciones } \\
\text { Totales }\end{array}$ & $\begin{array}{c}\text { Intervenciones coincidentes } \\
\text { con noticias de medios (al } \\
\text { menos 2) }\end{array}$ & $\begin{array}{c}\text { \% sobre Total } \\
\text { Intervenciones }\end{array}$ \\
\hline Sánchez & 38 & 17 & $44,74 \%$ \\
\hline Rajoy & 54 & 33 & $61,11 \%$ \\
\hline Total & 92 & 50 & $54,35 \%$ \\
\hline
\end{tabular}

Si analizamos estos resultados por bloques (tabla 2) observamos que la coincidencia entre los temas abordados por el candidato y los medios 
es mayor en aquellos aspectos en los que el participante, en principio, podría encontrarse más cómodo, es decir, Economía en el caso de Mariano Rajoy, y Bienestar en el de Pedro Sánchez.

Tabla 2. Nivel de coincidencia entre las intervenciones de los participantes en el debate de 2015 y las agendas de los medios en el trimestre anterior, por bloques

\begin{tabular}{|l|c|c|c|c|}
\hline & $\begin{array}{c}\text { Intervenciones } \\
\text { coincidentes Ec. } \\
\text { y Empleo }\end{array}$ & $\begin{array}{c}\text { \% Total } \\
\text { intervenciones }\end{array}$ & $\begin{array}{c}\text { Intervenciones } \\
\text { coincidentes Est. } \\
\text { Bienestar }\end{array}$ & $\begin{array}{c}\text { \% Total } \\
\text { intervenciones }\end{array}$ \\
\hline Sánchez & 10 & $41,67 \%$ & 7 & $50,00 \%$ \\
\hline Rajoy & 22 & $73,33 \%$ & 11 & $45,83 \%$ \\
\hline Total & 32 & $59,26 \%$ & 18 & $47,37 \%$ \\
\hline
\end{tabular}

Por lo que se refiere al debate del año 2016, en la tabla 3 se recoge el nivel de coincidencia en los temas abordados, en el conjunto de los bloques de Economía y Estado de Bienestar donde existían datos, por los candidatos participantes en dicho debate, así como la agenda de los medios en los tres meses anteriores; mientras que en la tabla 4 se indica el desglose por cada uno de los dos grandes bloques.

Tabla 3. Nivel de coincidencia entre las intervenciones de los participantes en el debate de 2016 y las agendas de los medios en el trimestre anterior al debate

\begin{tabular}{|l|c|r|}
\hline & $\begin{array}{c}\text { Intervenciones } \\
\text { Totales }\end{array}$ & $\begin{array}{c}\text { Intervenciones coincidentes } \\
\text { con noticias de medios }\end{array}$ \\
\hline Iglesias & 25 & $89,29 \%$ \\
\hline Rivera & 7 & $58,33 \%$ \\
\hline Sánchez & 10 & $66,67 \%$ \\
\hline Santamaría & 25 & $69,44 \%$ \\
\hline Total & 67 & $73,63 \%$ \\
\hline
\end{tabular}

Tal y como reflejan los datos anteriores, la coincidencia entre los temas y argumentaciones utilizadas por los distintos intervinientes y la agenda de los medios en el trimestre previo al debate es significativamente mayor en el caso de Pablo Iglesias, con un nivel de coincidencia que supera en casi 20 puntos al del segundo interviniente con mayor porcentaje de coincidencia, Soraya Sáenz de Santamaría, y en más de 30 puntos a Albert Rivera, el candidato que presenta un menor nivel de alineamiento entre sus argumentaciones. 
Tabla 4. Nivel de coincidencia entre las intervenciones de los participantes en el debate de 2016 y las agendas de los medios en el trimestre anterior, por bloque

\begin{tabular}{|c|c|c|c|c|}
\hline & $\begin{array}{c}\text { Coincidencia } \\
\text { Ec. y Empleo }\end{array}$ & $\mathbf{\%}$ & $\begin{array}{c}\text { Coincidencia } \\
\text { Estado del } \\
\text { Bienestar }\end{array}$ & $\%$ \\
\hline Iglesias & 17 & $89,47 \%$ & 8 & $88,89 \%$ \\
\hline Rivera & 6 & $66,67 \%$ & 1 & $33,33 \%$ \\
\hline Sánchez & 7 & $63,64 \%$ & 3 & $75,00 \%$ \\
\hline Santamaría & 20 & $90,91 \%$ & 5 & $35,71 \%$ \\
\hline Total & 50 & $81,97 \%$ & 17 & $56,67 \%$ \\
\hline
\end{tabular}

El liderazgo en términos de alineamiento con la agenda de los medios de Pablo Iglesias se reproduce en los dos bloques en proporciones prácticamente iguales. Al igual que sucedía en el debate a dos, si observamos el grado de coincidencia entre los temas y enfoques defendidos por los representantes de los partidos mayoritarios, de nuevo el grado de coincidencia en las agendas es mayor en aquellos temas que en principio resultan más favorables y acordes con el posicionamiento y prioridades de los intervinientes.

Si comparamos el grado de coincidencia entre los dos debates observamos que el grado de coincidencia de los representantes de los partidos participantes en los dos debates con la agenda de los medios es mayor en el caso del debate a cuatro que en el debate a dos, pudiendo deberse al hecho de que, al disponer de menos tiempo, la necesidad de centrarse en los grandes temas que generan opinión es mayor.

En la tabla 5 se recoge la coincidencia entre los enfoques de los distintos intervinientes en el debate a cuatro. En ella destaca el alto grado de coincidencia en las argumentaciones entre Rivera y Sánchez, que supone casi una de cada dos argumentaciones en los bloques de Economía y Empleo y Estado del Bienestar del primero y en una de cada tres de las del segundo (claramente por encima a la coincidencia en las argumentaciones entre Pablo Iglesias y Pedro Sánchez y de las de Pablo Iglesias y Albert Rivera, las menores entre los partidos que se encuentran en la oposición). 
Tabla 5. Nivel de coincidencia entre las argumentaciones de los participantes en el debate de 2016 y las agendas de los medios en el trimestre anterior, por bloque

\begin{tabular}{|c|c|c|c|c|}
\hline & Iglesias & Rivera & Sánchez & Santamaría \\
\hline Iglesias & - & $3,57 \%$ & $14,29 \%$ & - \\
\hline Rivera & $8,33 \%$ & - & $41,67 \%$ & $25,00 \%$ \\
\hline Sánchez & $20,00 \%$ & $33,33 \%$ & - & - \\
\hline Santamaría & - & $8,33 \%$ & - & - \\
\hline
\end{tabular}

Hemos analizado también en qué medios la coincidencia entre argumentaciones de los intervinientes y la agenda mediática se producía de forma textual (y casi literal), recogiéndose los datos en las tablas 6 y 7.

Tabla 6. Coincidencias textuales en el debate 2015 entre los intervinientes y las noticias de los medios

\begin{tabular}{|l|c|c|}
\hline & $\begin{array}{c}\text { E1 } \\
\text { Economista }\end{array}$ & Diario.es \\
\hline Sánchez & 1 & 1 \\
\hline Rajoy & - & - \\
\hline Total & - & - \\
\hline
\end{tabular}

Tabla 7. Coincidencias textuales en el debate 2016 entre los intervinientes y las noticias de los medios

\begin{tabular}{|l|c|c|c|c|}
\hline & Iglesias & Rivera & Sánchez & Santamaría \\
\hline 20 minutos & 1 & 1 & & \\
\hline Abc & & 1 & & 3 \\
\hline Europa Press & 1 & & 1 & \\
\hline E1 Español & 1 & & & \\
\hline E1 Mundo & 6 & 1 & 4 & \\
\hline E1 País & 8 & & 1 & 1 \\
\hline Expansión & 1 & & & 3 \\
\hline Público & 2 & & & \\
\hline RTVE & & & 1 & 2 \\
\hline
\end{tabular}

Resulta llamativa la coincidencia entre las intervenciones de Pablo Iglesias y los textos de diferentes medios, algo que sin duda vuelve a tener mucho que ver con la orientación dada por éste a sus intervenciones. Igualmente, se observa la existencia de una cierta relación entre las coincidencias de los candidatos con los medios y la alineación ideológica existente entre ambos. 


\section{Conclusiones}

Esta investigación muestra una coincidencia entre lo publicado por la prensa durante la precampaña y las intervenciones de los candidatos en los debates electorales televisados celebrados en campaña, que se sitúa en torno al 50\%, en los debates entre dos contendientes, y con porcentajes muy por encima $(73,63 \%)$ en el caso de los debates entre cuatro candidatos.

Los resultados reflejan también bastante similitud entre los dos bloques analizados del debate (Economía y Empleo y Estado del Bienestar) y los temas que en principio resultan más favorables y acordes con el posicionamiento y prioridades de cada candidato, al igual que ocurre, en cierta medida, entre la coincidencia ideológica de los candidatos y la orientación de los medios.

En definitiva, se aprecia una gran intersección y correlación entre las agendas mediática y política, produciéndose un evidente ensamblaje entre ambas y respondiendo al papel de la prensa, en el posicionamiento previo y jerarquización de los temas de campaña, y a la posterior enfatización de los mismos por parte de la televisión, en la línea de las teorías de la agenda-setting señaladas en este trabajo (López, Puentes y Rúas, 2017).

Coincidencias en las agendas de medios y los políticos que, bien o mal, se someten al escrutinio y la crítica ciudadana, cada vez mayor, a juzgar por las encuestas. Restaría por ver, en otro análisis, si esta complicidad entre los temas y prioridades señalados por la prensa y los políticos se produce también con los ciudadanos y las cuestiones consideradas como prioritarias por los mismos, a través, por ejemplo, de las redes sociales. 


\section{Bibliografía}

Bouza, F. (2004). "El área de impacto de la comunicación política: los ciudadanos ante el discurso público". International Review of Sociology, 14(2).

Ciampaglia, G., Flammini, A. y Menczer, F. (2015). "The production of information in the attention economy". Scientific reports, 5.

Diakopoulos, N. (2018). "Reporting in a machine reality: Deepfakes, misinformation, and what journalist can do about them".

Columbia Journalism Review. Disponible en https://www.cjr.org/tow_center/reporting-machine-realitydeepfakes-diakopoulos-journalism.php

European Comission (2018). Eurobarometer 464 on "Fake News and Disinformation on line". Disponible en: http:/ / ec.europa.eu/commfrontoffice/publicopinion/index.cf $\mathrm{m} /$ survey/getsurveydetail/instruments/flash/surveyky/2183.

Graves, L. y Cherubini, F. (2016). The Rise of Fact-Checking sites in Europe. Oxford: Reuters Institute.

Gualda, E., Rúas, J. (2019). "Teorías de la conspiración, credibilidad y confianza en la información”. Communication \& Society, 32(1), 179195

Guess, A., Nyhan, B. y Reifler, J. (2018). Selective Exposure to Misinformation. Evidence from the Consumption of Fake News during the 2016 US Presidential Campaign. Exeter: Department of Politics.

High-Level Expert Group on Fake news and Disinformation (2018). A multi-dimensional approach to disinformation. Report of the independent High level Group on fake news and online disinformation. European Commission, Directorate-General for Communication Networks, Content and Technology, Luxemburg. Disponible en: https://publications.europa.eu/en/publication-detail//publication/6ef4df8b-4cea-11e8-be1d01aa75ed71a1/language-en.

Iyengar, S. y Kinder, D. (1987). News That Matters. Chicago: University of Chicago Press.

Ksiazek, T. B., Malthouse, E. C. y Webster, J. G. (2010). "News-seekers and avoiders: Exploring patterns of total news consumption across media and the relationship to civic participation". Journal of Broadcasting \& Electronic Media, 54(4), 551-568. 
Kovach, B. y Rosenstiel, T. (2007). The Elements of Journalism: What Newspeople Should Know and the Public Should Expect. New York: Three Rivers Press.

Kovach, B. y Rosenstiel, T. (2007). Warp Speed: America in the Age of Mixed Media. New York: Twentieth Century Fund.

Ladd, J.M. (2012). Why Americans Hate the Media and How it Matters. Pricenton: Princenton University Press.

Lewis, S. C. y Westlund, O. (2015). "Big Data and journalism: Epistemology, expertise, economics and ethics". Digital Journalism, 3(3), 447-466.

López-Borrull, A., Vives-Grácia, J. y Badell, J. I. (2018). “Fake News, ¿amenaza u oportunidad para los profesionales de la información y la documentación?”. El Profesional de la Información, 27(6), 13461356.

López-Borrull, A. (2018). "La información y la comunicación, en coalición contra las fake news". Quaderns del CAC, 44, Vol. XXI, 95-96.

López-López, P., Oñate, P. y Chavero, P. (2018). "El horse-race campaign frente al issue-campaign en la agenda digital: elecciones presidenciales en América Latina en el período 2015-2017”. RISTI. Revista Ibérica de Sistemas e Tecnologías da Informaçao, 16, 270 282.

López-López, P. C.; Puentes-Rivera, I.; Rúas-Araújo, J. (2017). “La comunicación política en las elecciones gallegas del 25 de septiembre de 2016: la agenda temática en el debate de la TVG". En: Herrero-Gutiérrez, F. J.; Mateos-Martín, C.; ToledanoBuendía, S.; Ardèvol-Abreu, A.; Trenta, M. Del verbo al bit (Cuadernos Artesanos de Comunicación). Tenerife: Universidad de La Laguna, 1431-1460.

https:/ / dialnet.unirioja.es/servlet/articulo?codigo $=6065257$

López, X., Rodríguez, A.I. y Álvarez-Gromaz, L. (2016). "El fact checking como reclamo y como servicio en los cibermedios. Análisis de las experiencias de The Washington Post y The Guardian". Telos: Cuadernos de Comunicación e Innovación, 103, 74-83. Magallón-Rosa, R. (2018). "Nuevos formatos de verificación. El caso de Maldito Bulo en Twitter". Sphera Pública, 18 (1), 41-65.

McCombs, M. y Shaw, D. (1972). "The agenda setting function of mass media". Public Opinion Quarterly, 36. 
McNair, B. (2018). Falsehood, Fabrication and Fantasy in Journalism. Londres: Routledge.

Naderi, N. y Hirst, G. (2018). "Automated Fact-Checking of Claims in Argumentative Parliamentary Debates". Proceedings of the First Workshop on Fact Extraction and Verification (FEVER). Disponible en: https://aclanthology.info/papers/W18-5509/w18-5509

Nicolaisen, J. (2013). Climbing Mount Dependable: How to detect misinformation on the Internet. Proceedings of the International Conference on Internet Studies, China.

Nigro, P. M. (2018). "Causas de la pérdida de la confianza en la prensa y estrategias para su restablecimiento en un contexto de incertidumbre", Hipertext.Net, 17, 54-63.

Ornebring, H. (2019). "Journalism cannot solve journalism's problems. Journalism, 20(1), 226-228.

Patel, M. (2017). Detection of Malicious Authored News Articles. Albert Nerken School of Engineering. Tesis doctoral. Disponible en: https://cooper.edu/sites/default/files/uploads/assets/MirajPa tel_Masters_Thesis.pdf.

Patwari, A, Goldwasser, D. y Bagchi, S. (2017). "TATHYA. A multiclassifier system for detecting check-worthy statements in political debates. Proceedings of the 2017 ACM Conference on Information and Knowledge Management, pp. 2259-2262. Disponible en: https://dl.acm.org/ citation.cfm?id=3133150

Pingree, R., Watson, B., Sui, M. et al (2018). "Checking facts and fighting back: Why journalists should defend their profession". Plos One, 13(12), 1-14. Disponible en: https://doi.org/10.1371/journal.pone.0208600

Redondo, M. (2018). Verificación digital para periodistas. Manual contra bulos $y$ desinformación internacional. Barcelona: UOC.

Reese, S., Gandy, O. y Grant, J. (2001). Framing Public Life: Perspectives on Media and Our Understanding of the Social World. London: Routledge.

Rúas, X., Mazaira, A. y Puentes, I. (2017). "Modelo de verificación de feitos (fact-ckecking) aplicado ao Parlamento de Galicia". Alén das fronteiras: Redes na diversidade. I Congreso Internacional da Asociación de Investigadores e Investigadoras en Comunicación (Agacom), 20 y 21 de noviembre, 325-340. 
Rúas, X., Mazaira, A. y Rodríguez, A. (2017). "Nuevos medios y medios tradicionales en la red. Espacios de opinión e interacción política en la era Trump”. Icono 14, 16 (1), 86-113.

Sadiku, T. Eze y Musa, S. (2018). "Fake News and Missinformation". International Journal of Advances in Scientific Research and Engineering (IJASRE), 187-190.

Shearer, E. y Gottfried, J. (2017). "News use across social media platforms 2017". Pew Research Center. Disponible en: http://www.journalism.org/2017/09/07/ news-use-acrosssocial-media-platforms-2017/

Steen, S. (2019). "Journalism's epistemic crisis and its solution: Disinformation, datafication and source criticism", Journalism, 20(1), 185-189.

Walton, D. (2005). Fundamentals of critical argumentation. Cambridge: Cambridge University Press.

Wardle, C. y Derakhshan, H. (2017). "Information Disorder: Toward an interdisciplinary framework for research and policy making". Council of Europe. Disponible en:

https:/ / rm.coe.int/information-disorder-toward-aninterdisciplinary-framework-for-researc/168076277c

Wasserman, H. (2018). 'Relevance, resistance, resilience: Journalism's challengues in a global world". Journalism, 20(1), 229-232.

Weaver, D. H. (1991). "Issue salience and public opinion: Are there consequences of agenda-setting". International Journal of Public Opinion Research, 3, 53-68.

Wintersieck, A.L. (2017). "Debating the Truth: The Impact of FactChecking during Electoral Debates". American Politics Research, 45(2), 304-331.

Yang Wnag, W. (2017). "Liar, liar pants on fire: a new benchmark dataset for fake news detection". Disponible en: https://arxiv.org/abs/1705.00648

Zubiaga, A., Liakata, M. Procter, R.; Wong, G. y Tolmie, P. (2016). "Analysing how people orient and spread rumours in social media by looking at conversational threads". Plos One, 11 (3). https://doi.org/10.1371/journal.pone.0150989. 


\section{Reconocimiento de la investigación}

Este capítulo forma parte de los trabajos desarrollados en el marco del proyecto de I+D+I (Retos) "DEBATv, Debates Electorales Televisados en España: Modelos, Proceso, Diagnostico y Propuesta" (Ref. CSO2017-83159-R), financiado por el Ministerio de Economía, Industria y Competitividad (MINECO), la Agencia Estatal de Investigación (AEI) y el Fondo Europeo de Desarrollo Regional (FEDER) de la Unión Europea (UE). Surge también de la actividad investigadora de XESCOM: Red Internacional de Investigación de la Gestión de la Comunicación, proyecto de investigación financiado en régimen de concurrencia competitiva por la Consellería de Cultura, Educación e Ordenación Universitaria de la Xunta de Galicia (ED341D R2016/019) 



\title{
Seducir a la audiencia televisiva: la autopromoción permanente
}

\author{
Iván Puentes-Rivera \\ Universidad de A Coruña \\ Paulo Carlos López-López \\ Pontificia Universidad Católica del Ecuador Sede Ibarra \\ Montse Vázquez-Gestal \\ Universidade de Vigo
}

PARA CITAR: Puentes-Rivera, I., López-López, P. C. y VázquezGestal, M. (2019). "Seducir a la audiencia televisiva: la autopromoción permanente". En Conde-Vázquez, E., Fontenla-Pedreira, J. y RúasAraújo, J. (Eds.), Debates electorales televisados: del antes al después (pp. 171192). Cuadernos Artesanos de Comunicación, cac154. La Laguna (Tenerife): Latina. DOI: $10.4185 /$ cac154

\section{Resumen}

El presente capítulo reflexiona sobre las estrategias de autopromoción que actualmente despliegan los operadores de televisión para publicitar los debates electorales que emiten. Se toma para ello como ejemplo las últimas elecciones al Parlamento de Cataluña, las celebradas en diciembre del año 2017, de las que salió la actual configuración de la cámara legislativa catalana y el Gobierno de la Generalitat presidido por Joaquim (Quim) Torra (Partit Demòcrata), protagonista 
indiscutible de una buena parte de la actualidad política nacional. Un contexto en el que, si cabe, se evidencia aún más el protagonismo del debate y su papel como facilitador de argumentos y propuestas que propicien el posicionamiento de la ciudadanía, su mejor conocimiento de la realidad y, por tanto, su participación democrática.

Con esta finalidad y, de acuerdo con todo lo expuesto, se han estudiado las estrategias de autopromoción empleadas por las televisiones que programaron debates electorales entre los diferentes candidatos que se presentaron a las referidas elecciones al Parlament de Catalunya, concretamente Televisión Española (TVE), Televisió de Catalunya (TV3) y La Sexta.

Palabras clave: debates televisados, autopromoción, programación, publicidad, audiencias

\section{Introducción}

S E trata de un formato que tardó en consolidarse en España, si es $\checkmark$ que tal afirmación se puede realizar con rotundidad aún hoy en día, pero lo cierto es que los debates electorales televisivos son, cuando menos, una costumbre asentada en las últimas convocatorias electorales de ámbito nacional y en muchas de las autonómicas y municipales. Al margen del episodio aislado que supuso el primer debate televisivo en la historia democrática de España, el que enfrentó a José María Aznar (Partido Popular), como líder de la oposición y al entonces Presidente del Gobierno, Felipe González (Partido Socialista Obrero Español), en el año 1993, no es hasta 2008 cuando los electores españoles tienen la oportunidad de presenciar de nuevo un evento de este tipo. Un debate en televisión, también con el clásico formato cara a cara, entre el Presidente José Luis Rodríguez Zapatero (PSOE) y el aspirante Mariano Rajoy (PP) que inició la nueva dinámica en relación a estos formatos televisivos, marcada por la celebración de al menos uno, en cada una de las citas electorales siguientes, hasta la fecha.

Más allá de ser un formato para televisión, esta consolidación del debate electoral entronca con el nuevo contexto político que se inicia en el país tras la última crisis económica, caracterizado por la quiebra 
del esquema clásico de partidos políticos, la merma en la confianza de las instituciones públicas, el rechazo a la corrupción y a los privilegios sociales asociados al ejercicio de la política y, en consecuencia, el incremento del protagonismo ciudadano, traducido en una reivindicación constante y la asunción por parte de los partidos de viejo y nuevo cuño de una mayor participación de la ciudadanía en los asuntos públicos y una mayor y casi permanente capacidad de decisión sobre los mismos, que vaya más allá de la mera consulta electoral cada cuatro años. Ese ejercicio activo de la ciudadanía exige, sin duda, una mayor información, que debería llevar a la conformación de una opinión pública mejor formada $\mathrm{y}$, en último término, a una mayor calidad democrática del país.

Es en esta dinámica en la que los debates electorales televisivos entroncan con las exigencias ciudadanas y se convierten en un elemento básico, o al menos importante, en la configuración de la opinión pública, como resultado de la confrontación de ideas, propuestas y, por supuesto, como un ejercicio más de la rendición de cuentas, pasadas y previas, y de la transparencia que se exige a los representantes públicos $y$, en general, a todas las administraciones y entes públicos, incluidas las televisiones (López-López, Puentes-Rivera y Rúas-Araújo, 2017).

En todo caso, al margen de esta función social, los debates también son, como ya se ha señalado, un programa o formato de televisión, enmarcado inicialmente dentro del género de la información, pero con una influencia clara, como ocurre con casi todos los formatos y géneros, del entretenimiento, traspasando, por tanto, también la frontera del llamado infoentretenimiento. Esto ha originado una evolución de formatos de debate más asépticos y encorsetados a otros más dinámicos y abiertos, más orientados, o, al menos, igual de orientados a la información que al entretenimiento del telespectador. Una evolución y diferencias de formatos que alcanzan diferentes matices entre las televisiones de titularidad pública y privada.

Algo similar ocurre con la autopromoción de esos debates por parte de los operadores de televisión que los emiten u organizan. Estrategias publicitarias que hoy en día van mucho más allá del clásico y simple 
spot dando cuenta del día y hora de emisión y que presentan también notables diferencias entre unas cadenas y otras, fundamentalmente en función de su carácter privado o público, pero también con alguna influencia a mayores del ámbito geográfico, nacional o autonómico, del que se hable.

\section{Marco teórico}

La historia de los debates electorales en España, tal y como se ha apuntado, es errática, tanto en frecuencia como en intensidad. Salvo el hecho puntual de comienzos de la década de los 90 , hasta bien entrada la década de 2000 (2008) no se apuesta por este formato, fundamentalmente por el temor que infunda en los partidos políticos y los candidatos, convencidos de que era poco lo que podían ganar en ellos y mucho lo que podían perder (Campo Vidal, 2017). Esto explica la ausencia prácticamente total de debates electorales en televisión durante casi 30 años de democracia, en los que, hablando de elecciones generales, sólo se celebraron dos y en la misma campaña electoral, la de 1993. En ellos se demostró, efectivamente, los riesgos que el formato podía acarrear para quien ostenta el poder y no tiene a priori un riesgo cierto de perderlo, rol que en aquel entonces encarnaba el presidente Felipe González, quien salió seriamente tocado del primer cara a cara con José María Aznar, líder del Partido Popular, celebrado en Antena 3.

Por este y otros motivos, lo cierto es que la dinámica posterior, en las elecciones de 1996, 2000 y 2004 fue, con ligeros matices, siempre la misma, un candidato de la oposición que pedía insistentemente la celebración de los debates y un presidente del Gobierno que con unas u otras excusas finalmente abortaba su celebración. Esta rutina cambió en 2008, año en el que concurren dos factores: en primer lugar, el compromiso electoral de José Luis Rodríguez Zapatero (aspirante a la reelección como Presidente de Gobierno), quien en las elecciones anteriores (2004), cuando el Presidente Mariano Rajoy se negó a debatir con él en televisión, había hecho de la celebración debates uno de sus principales compromisos electorales si finalmente lograba, como ocurrió, ser Presidente y, en segundo lugar, la crisis económica, que empezaba a asomar en 2008, iniciándose con ella el cambio de modelo 
político comentado y esa mayor demanda de transparencia y rendición de cuentas por parte de los representantes políticos. De tal forma que, desde entonces, en los últimos 11 años, no ha habido ya ningún proceso electoral a Cortes Generales sin debate, efecto que ha tenido su contagio en las elecciones autonómicas y en muchas municipales.

La frecuencia ha sido, por tanto, errática, como se comentaba, pero también varía su intensidad. En las elecciones generales de 2011 se celebraron dos debates de este tipo, un cara a cara entre Alfredo Pérez Rubalcaba (PSOE) y Mariano Rajoy (PP) y un debate a tres entre los líderes de PSOE, Podemos y Ciudadanos, al que declinó asistir el Partido Popular. Otros dos fueron los encuentros celebrados en 2015, un nuevo cara a cara entre Rajoy y Pedro Sánchez (PSOE) y un debate múltiple entre los candidatos de los cuatro principales partidos, aunque Mariano Rajoy cede el atril del PP a la Vicepresidenta del Gobierno, Soraya Sáenz de Santamaría. Finalmente, en 2016 se celebra un único debate en el que, aquí sí, participan los cuatro principales aspirantes a la Presidencia del Gobierno.

Con esta evolución histórica de fondo, resulta pertinente, además del efecto que este tipo de programas televisivos tienen en el comportamiento de las audiencias, en el voto de los electores, en definitiva (López-López, Puentes-Rivera y Rúas-Araújo, 2016), estudiar la estructura y el tipo de narrativa audiovisual que los caracteriza en cada momento (Benoit y Brazeal, 2002; Cantavella Blasco et al., 2008; Quintas y Quintas, 2010), línea de investigación predominante en el presente artículo.

Tal y como se apuntaba en los párrafos iniciales, los principales cambios que han experimentado los debates electorales en televisión tienen que ver con la forma, con el tipo de programa que generan; observándose una evolución caracterizada por el creciente poder de los medios a la hora de hacer valer su criterio (Santiago, 2016), guiado fundamentalmente por el interés televisivo, frente al poder de los partidos políticos que inicialmente condicionaban absolutamente el formato, guiados por un interés meramente electoral y partidario, no público o de audiencia. 
De acuerdo con ello, gana en importancia también la figura del presentador o moderador. Cierto es que en España los debates electorales han estado siempre moderados por profesionales de reconocido prestigio, como Luis Mariñas u Olga Viza, referentes, incluso, del periodismo en España, como el histórico presidente de la Academia de la Televisión Manuel Campo Vidal o presentadores estrella de los espacios informativos de cada cadena, Ana Blanco (TVE), Ana Pastor (La Sexta), Pedro Piqueras (Telecinco) o Vicente Vallés (Antena 3). El cambio consiste en que en la actualidad el margen de acción de los profesionales es mayor, pasando de ser meros moderadores, administradores de tiempos, a coprotagonizar el debate, junto con los políticos: articulan buena parte del guion, preguntan directamente, repreguntan, introducen temas y giros en el debate, con la intención de ofrecer programas ágiles, dinámicos y ajustados a los gustos de consumo de las audiencias actuales. Esos presentadores estrella son, al mismo tiempo, un recurso publicitario, de autopromoción, más del propio debate, pues, al más puro estilo de la publicidad clásica, con su presencia aportan valor al producto promocionado, en este caso, el debate (Ogilvy, 1990 y 1994; Bassat, 2008).

Se articula así una fructuosa confluencia entre la publicidad y la política que afecta a todos los ámbitos de la comunicación electoral y se traduce, por ejemplo, en la creación de marcas personales (ZP: Zapatero Presidente, que llego a convertirse en casi un sobrenombre del candidato socialista), en guiones y estructuras de debates electorales mucho más televisivas, más vinculadas al entretenimiento, o en nuevas fórmulas de autopromoción que, como se ha apuntado, trascienden el clásico spot.

Hablar de publicidad es hablar de creatividad, es decir, de la facultad o habilidad para construir mensajes comunicativos que resulten innovadores (Hernández Martínez, 1999), en forma, en contenido o en ambos planos. Creatividad que, con mayor o menor presencia, se aplica tanto a los debates como a las formas de autopromoción analizadas, aunque muy condicionadas por el carácter público o privado de la televisión, que determinará, como se verá, el recurso a fórmulas más o menos clásicas en este aspecto, más puramente informativas o más 
emocionales. Se recurre incluso, al igual que ocurre con las técnicas actuales de marketing surgidas de las neurociencias, al poder de decisión del llamado cerebro reptiliano (Rúas-Araújo y García-Sanz, 2018), que, con el afán de conservar la especie, responde a estímulos básicos y simples. En definitiva, una combinación de sencillez, originalidad y emoción que define la comunicación publicitaria actual (Montañés García, 2017), la puramente comercial y también, en ocasiones, la vinculada a productos electorales como los debates televisivos.

\section{Método}

Tal y como ya se ha apuntado, el presente capítulo tiene por objeto analizar los usos y tendencias actuales en los recursos de autopromoción que los operadores de televisión emplean en la actualidad para difundir entre sus públicos los debates electorales que emiten; tomando para ello como muestra los tres debates celebrados en el contexto de la campaña electoral para las elecciones al Parlament de Cataluña del año 2017, organizados por TVE (Televisión Española), La Sexta y TV3 (Televisió de Catalunya) antes de la votación del día 21 de diciembre.

De acuerdo con ello, basándose en una metodología cualitativa y descriptiva, se analizan las diferentes estrategias y recursos de autopromoción de los debates electorales archivados en los portales web de los respectivos operadores, llevando a cabo una descripción detallada de los mismos que permita, posteriormente, comparar los recursos de las diferentes cadenas de acuerdo con tres aspectos o variables: si se trata de televisiones públicas o privadas, si son entes de ámbito nacional o regional y si, desde el punto de vista editorial, se identifican con una línea más progresista o conservadora y más o menos afín a los postulados de los llamados partidos constitucionalistas o unionistas o a los de los independentistas.

El vaciado de contenido de los portales institucionales antes indicado arroja el uso de tres grandes recursos de autopromoción por parte de todos los operadores: el anuncio o spot destinado a su emisión en los bloques publicitarios de la cadena, diversas informaciones incluidas en 
los espacios informativos emitidos con carácter previo a la celebración del debate e información escrita a modo de noticia, acompañada en ocasiones de diferentes recursos audiovisuales, en las páginas web de las televisiones: www.ccma.cat/tv3, www.rtve.es y www.lasexta.com.

En concreto, los debates electorales que se han analizado son los referenciados en la siguiente tabla.

Tabla 1. Debates electorales televisivos en las elecciones al Parlamento de Cataluña de 2017

\begin{tabular}{|c|c|c|c|}
\hline Fecha & Hora & Operador & Canales \\
\hline $7 / 12 / 2017$ & $22: 15$ & TVE & $\begin{array}{c}\text { La 1 } \\
\text { Canal 24 horas } \\
\text { Ràdio 4 (RNE) } \\
\text { www.rtve.es }\end{array}$ \\
\hline $17 / 12 / 2017$ & $21: 30$ & Atresmedia & La Sexta \\
\hline $18 / 12 / 2017$ & $22: 00$ & $\begin{array}{c}\text { Televisió de } \\
\text { Catalunya }\end{array}$ & $\begin{array}{c}\text { TV3 } \\
\text { Catalunya Rádio } \\
\text { www.324.cat }\end{array}$ \\
\hline
\end{tabular}

Fuente: Elaboración propia

Todos los debates señalados fueron debates múltiples, entre los candidatos y candidatas, no siempre cabezas de lista, de los siete principales partidos de la comunidad autónoma, aquellos que gozaban de representación parlamentaria hasta el momento.

Tabla 2. Candidatos participantes en cada uno de los debates electorales de las elecciones catalanas de 2017

\begin{tabular}{|c|l|c|l|l|}
\hline \multicolumn{1}{|c|}{ Pebate } & \multicolumn{1}{|c|}{ Partido } & Siglas & & \multicolumn{1}{|c|}{ Representante } \\
\hline $\mathbf{7 / 1 2 / 2 0 1 7}$ & Junts per Catalunya & JxCat & & Jordi Turull \\
\hline & Esquerra Republicana de Catalunya & ERC & & Roger Torrent \\
\hline & Ciudadanos & C's & & Inés Arrimadas \\
\hline & Partit dels Socialistes de Catalunya & PSC & & Miquel Iceta \\
\hline & Partido Popular & PP & & Xavier García Albiol \\
\hline & Candidatura d'Unitat Popular & CUP & & Carles Riera \\
\hline & Catalunya en Comú-Podem & CeC & & Xavier Domènech \\
\hline $\mathbf{1 7 / 1 2 / 2 0 1 7}$ & Junts per Catalunya & JxCat & Josep Rull \\
\hline & Esquerra Republicana de Catalunya & ERC & Carles Mundó \\
\hline & Ciudadanos & C's & & Inés Arrimadas \\
\hline & Partit dels Socialistes de Catalunya & PSC & & Miquel Iceta \\
\hline & Partido Popular & PP & Xavier García Albiol \\
\hline & Candidatura d'Unitat Popular & CUP & Vidal Aragonés \\
\hline & Catalunya en Comú-Podem & CeC & & Xavier Domènech \\
\hline
\end{tabular}




\begin{tabular}{|l|l|c|l|l|}
\hline $\mathbf{1 8 / 1 2 / 2 0 1 7}$ & Junts per Catalunya & JxCat & Jordi Turull \\
\hline & Esquerra Republicana de Catalunya & ERC & Marta Rovira \\
\hline & Ciudadanos & C's & Inés Arrimadas \\
\hline & Partit dels Socialistes de Catalunya & PSC & Miquel Iceta \\
\hline & Partido Popular & PP & Xavier García Albiol \\
\hline & Candidatura d'Unitat Popular & CUP & Carles Riera \\
\hline & Catalunya en Comú-Podem & CeC & Xavier Domènech \\
\hline
\end{tabular}

Fuente: Elaboración propia

Tal y como se puede observar en la tabla anterior, hay tres partidos, Junts per Catalunya, Esquerra Republicana y la CUP, que participan con diferentes representantes en unos y otros debates. La CUP lo hace por una cuestión de estrategia política, pero JxCat y ERC se ven forzados a ello debido a que sus candidatos a president, Carles Puigdemont y Oriol Junqueras, están, respectivamente, fugado de la justicia fuera del país, uno y encarcelado debido a la organización y celebración del referéndum independentista ilegal del 1 de octubre del mismo año, el otro. Las restantes candidaturas sí están presentes en los tres debates con sus respectivos cabezas de lista.

\section{Autopromoción de los debates electorales en televisión 4.1. Radio Televisión Española (TVE)}

La cadena pública estatal, Televisión Española (TVE), organiza el primer debate de los tres celebrados y emplea una doble estrategia de programación. Emite el programa para la comunidad autónoma de Cataluña a través de La 1, canal insignia de la cadena y de Ràdio 4 de Radio Nacional de España, exclusivo de Cataluña, mientras que para el resto del país el debate se emite por el Canal 24 horas, canal temático, centrado en información, de la corporación pública; además de retransmitirse también por streaming a través de la página web de RTVE. El debate se celebra en Cataluña, en los estudios de TVE en Sant Cugat del Vallés y se desarrolla íntegramente el catalán, acompañado de traducción simultánea en la emisión para el Canal 24 horas y la web.

En la desconexión territorial para Cataluña TVE recurre a un spot de autopromoción del debate (imagen 1), que no ha sido publicado en la web ni en medios digitales, por lo que no puede ser analizado en su totalidad. No obstante, en la noticia incluida en el Telediario del mismo 
día sobre la celebración del debate (https://goo.gl/o28WLp), sí se incluyen algunos planos del mencionado spot, que permiten un análisis parcial del mismo.

Imagen 1. Spot de autopromoción del Debate de TVE

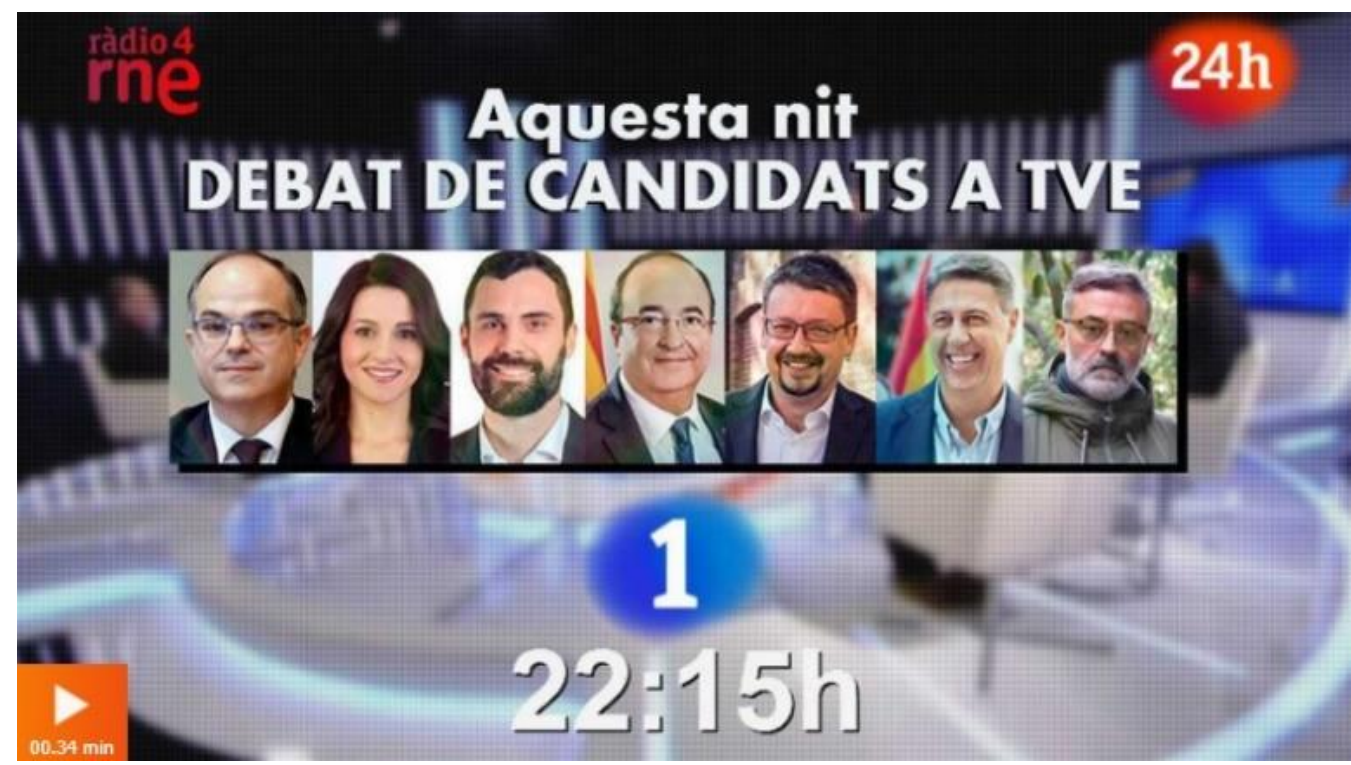

Fuente: rtve.es (https://goo.gl/o28WLp)

Tal y como se observa, en el caso de la televisión pública estatal el protagonismo del spot es para los candidatos a president y/o representantes de los diferentes partidos políticos que participan en el debate, ordenados, con matices, de izquierda a derecha en función del resultado obtenido en las elecciones autonómicas anteriores, asumiendo, por tanto, el orden de importancia y criterio de representatividad que, en cuanto a la distribución de tiempos, establece la LOREG (Lei Orgánica del Régimen Electoral General) en todo aquello que tenga que ver con el tratamiento informativo electoral en los operadores públicos.

Es verdad que tal afirmación puede ser matizada, puesto que en primer lugar aparece el representante de JxCat, coalición en la que se integra el PDeCAT (Partit Demócrata), partido del último president, Carles Puigdemont, pero ni JxCat, ni tan siquiera el PDeCat, existían en los anteriores comicios, en los que el predecesor de este último partido, Convergència Democrática de Catalunya (CDC), concurrió a las elecciones en coalición con ERC y otros partidos de menor entidad, con una plataforma denominada Junts pel Sí (JxSî), Aun así, se opta 
por asimilar a JxCat como heredera de esa coalición que ganó las elecciones y se ignora a Esquerra, que aparece en tercera posición, por detrás de Ciudadanos, pese a ser parte fundamental de JxSí y miembro del último gobierno, junto con el PDeCat.

Al igual que las demás cadenas, TVE publicita el debate que organiza a través de sus servicios informativos, incluyendo en el Telediario del día en cuestión una noticia sobre la emisión del programa y diversos aspectos relacionados con el mismo (https://goo.gl/o28WLp). La noticia se incluye en titulares y se ofrece con una introducción previa de la presentadora $\left(7^{\prime} 15^{\prime \prime}\right)$, informando sobre la hora y canales en los que se emitirá y poniendo en valor el hecho de que se trate del primero de los debates previstos en esta campaña electoral. La noticia del Telediario de TVE incluye una conexión en directo con Barcelona, con los estudios de Sant Cugat del Vallés para presentar al moderador del debate, el periodista Quim Barnola, que se encarga, además, de explicar los aspectos más concretos del programa (imagen 2), como los temas a tratar, el orden de intervenciones, los tiempos de los que disponen cada uno de los representantes, etc... Finalmente, se inserta una pieza de los candidatos, en el mismo orden que se ha explicado en relación al spot, con declaraciones de cada uno de ellos acerca de las expectativas que tienen depositadas en el debate y que, en cierto modo, funciona también como cebo o elemento para captar la atención y motivar al espectador a ver el programa.

Imagen 2. Tratamiento de la celebración del debate en el Telediario de TVE

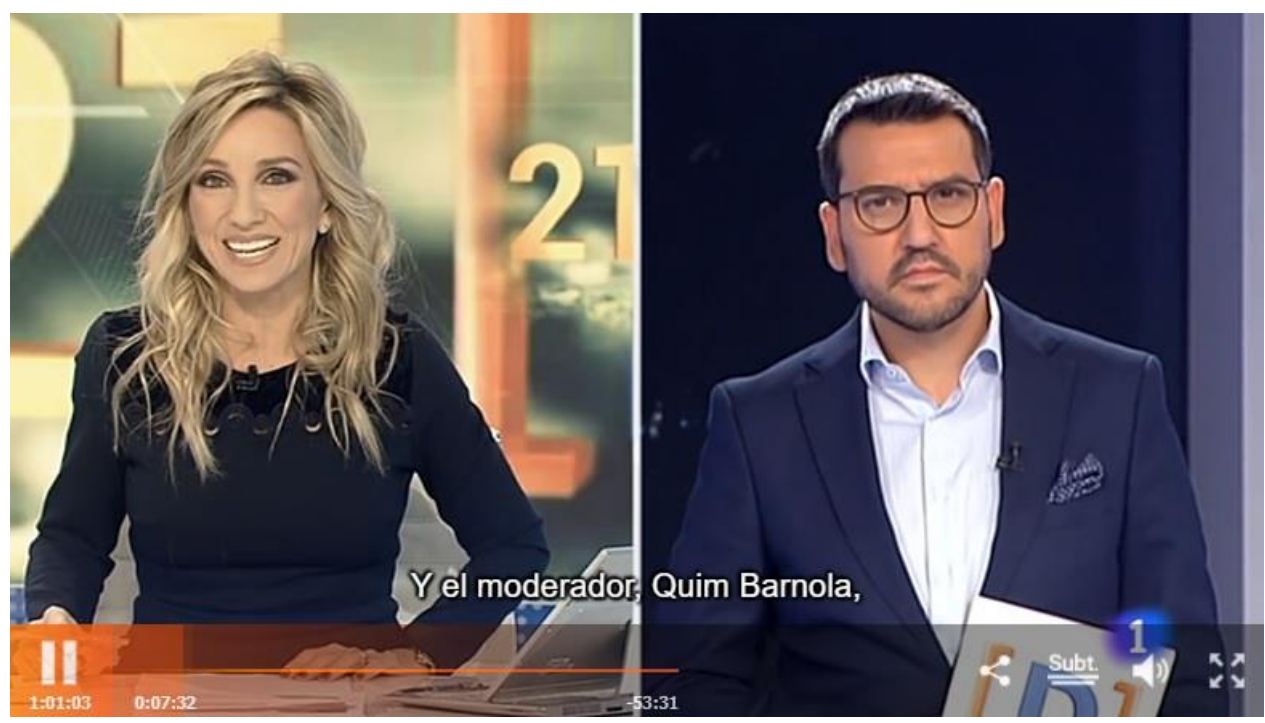

Fuente: rtve.es (https://goo.gl/o28WLp) 
Por último, también en el portal de RTVE se incluye una noticia escrita sobre la celebración del debate, ubicada en la sección de información corporativa (https://goo.gl/njBnAf), llamada "Sala de Comunicación". Se trata de una nota de prensa genérica que, bajo el título "Elecciones del 21-D en RTVE: gran debate el día 7, entrevistas y especiales informativos", explica el tratamiento y cobertura que la cadena va a desplegar con motivo de las elecciones catalanas, planificación que incluye el debate celebrado en esta jornada.

\subsection{La Sexta}

La cadena privada de Atresmedia, que ha hecho del proceso catalán uno de los temas estrella de su programación, con un seguimiento constante en diversos espacios informativos (Noticias $\mathrm{La}$ Sexta), magazines (Al Rojo Vivo) y de infoentretenimiento ( La Sexta Noche, El Objetivo, etc.) acoge el segundo de los debates previstos en estas elecciones.

La Sexta opta también por emitir el debate desde Cataluña, pero no recurre a sus platós ordinarios, sino que crea un escenario específico para la ocasión en un centro cultural de Barcelona llamado Utopía, lo que aporta al debate una estética urbana, actual, incluso industrial, alejada de la escenografía clásica de un programa de este tipo. La Sexta no hace distinción geográfica, emite por el canal principal el debate para toda España y el idioma seleccionado en esta ocasión es el castellano, detalle sorprendente en términos políticos, en una comunidad tan sensibilizada con la defensa de la lengua propia y más tratándose de unas elecciones autonómicas en pleno proceso independentista, pero comprensible en términos de programación y audiencia televisiva.

El spot de La Sexta para promocionar el debate (https://goo.gl/wYBzkr) tiene una duración de 20 segundos y publicita no sólo este espacio, sino también el programa de análisis previo, una de las apuestas de la cadena para aprovechar y estirar la franja horaria en la que retener a la audiencia interesada en el tema. Además de este detalle de contenido, destaca también la factura del anuncio en cuanto a la forma, pues, frente a la sobriedad y el clasicismo de TVE, La Sexta recurre a una voz en off con tono épico y resaltando 
la trascendencia del programa, rozando incluso la hipérbole, además de singularizarlo mediante el recurso a un título, un nombre propio para el espacio, El Debat: "información y debate cuatro días antes de las elecciones que pueden aclarar el panorama catalán. A las nueve de la noche la última hora y todos los datos con Antonio García Ferreras y a las nueve y media, representantes de las principales fuerzas políticas catalanas en un debate moderado por Ana Pastor. Este domingo, 17D, El Debat, en La Sexta".

La música seleccionada contribuye, en coherencia, a ese ambiente épico y trascendente antes señalado. Se trata de una ambientación sonora muy cinematográfica, casi de acción. Un entorno discursivo que se cierra perfectamente con una imagen gráfica específica, también moderna, original, que recuerda a una madeja de hilos con los colores ocres, rojos y amarillos de la simbología institucional de Cataluña y de España, que vendría a funcionar como una metáfora visual de la difícil situación política y social con la que se llega y se vivirán las elecciones en cuestión.

Imagen 3. Grafismo empleado por La Sexta en la promoción del debate

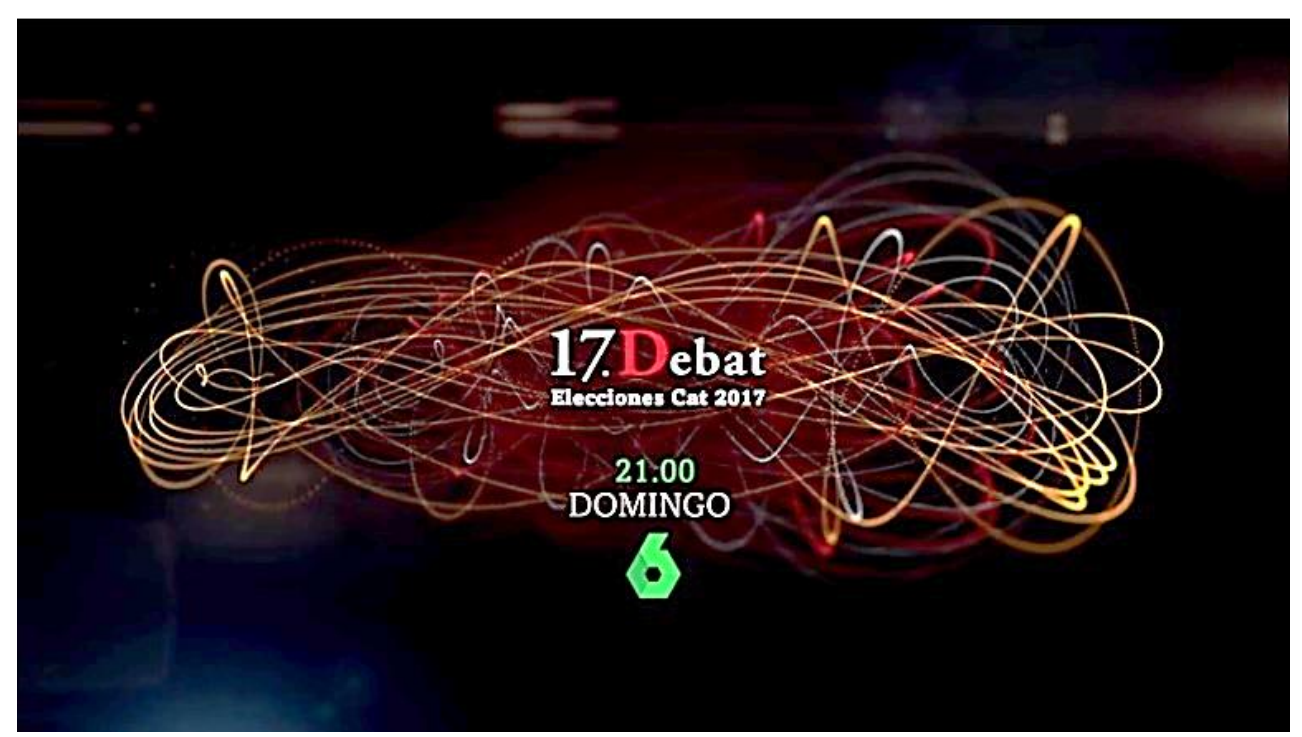

Fuente: lasexta.com (https://goo.gl/wYBzkr)

Este spot destaca también por el contenido, alejado nuevamente del clasicismo de TVE, aspecto que se comprueba desde el primer plano, en el que se muestra un balcón con una bandera de Cataluña y otra de España, juntas, en convivencia, para pasar a continuación a una imagen 
del Parlament, unos planos de una manifestación con simbología independentista (fundamentalmente, la bandera catalana con la estrella -la estelada- y diversos complementos amarillos en la ropa de los manifestantes). Le siguen imágenes de otra manifestación, en este caso contraria a la independencia de Cataluña y, por tanto, plagada de simbología oficial española y catalana, un plano medio del ex president Puigdemont en un acto público y, ahora sí, al final del spot, imágenes de los políticos que participarán en el debate, junto con la moderadora del mismo, Ana Pastor y el presentador del programa de análisis previo, Antonio García Ferreras.

La presencia de El Debat en los servicios informativos del canal, La Sexta Noticias, es también abundante, tal y como ocurre en la jornada de celebración del mismo (https://goo.gl/eX78MZ). En el informativo de ese día se incluye la típica pieza que explica la hora de emisión, el formato, quienes intervendrán, en qué orden, etc. usando para ello imágenes de recurso de las diferentes candidaturas y un total de la presentadora poniendo en valor el rasgo diferencial, la seña de identidad de este debate frente a otros, la flexibilidad y el hecho de que las reglas hayan sido marcadas por los profesionales, los periodistas, $\mathrm{y}$ aceptadas por los políticos, no a la inversa. Se incide, además, en que frente al clásico monólogo de los candidatos, en El Debat los políticos deberán responder a preguntas formuladas por los periodistas.

El canal de Atresmedia no se limita a este recurso más o menos habitual, sino que aprovecha diferentes programas de su parrilla, fundamentalmente magazines de actualidad, como Al Rojo Vivo o La Sexta Noche, para introducir diversos contenidos sobre el debate que sirvan como cebo a la audiencia y no sólo el día de emisión del mismo, sino que desde varias jornadas previas se lleva a cabo por este método una intensa campaña de autopromoción del programa. Es, en todo caso, el magazine de mañana presentado por García Ferreras, Al Rojo Vivo (ARV), uno de los buques insignia de la cadena, quien lleva el mayor peso de esta estrategia de autopromoción desde casi una semana antes de la celebración del debate, llegando a hacer contenido televisivo de todos y cada uno de los pasos previos, de asuntos que habitualmente se resuelven en reuniones de oficina sin mayor trascendencia pública. Destaca, por ejemplo, la emisión del sorteo por el cual se asignaron las 
posiciones de los candidatos en el plató, además del orden de intervención y cierre de los mismos (https://goo.gl/ADQ6Ze), algo para lo que se recurre a una conexión en directo con el centro cultural en el que se celebrará el debate y a representantes de las diferentes candidaturas que, ante las cámaras de La Sexta y el análisis de resultados de los tertulianos y expertos en comunicación política de ARV, extraen bolas de unas urnas a fin de realizar el mencionado sorteo (imagen 4). A todo ello le acompaña un elaborado grafismo que va ilustrando en pantalla el resultado de cada uno de esos aspectos a sortear.

Imagen 4. Emisión en directo en ARV del sorteo para decidir posiciones e intervenciones en El Debat

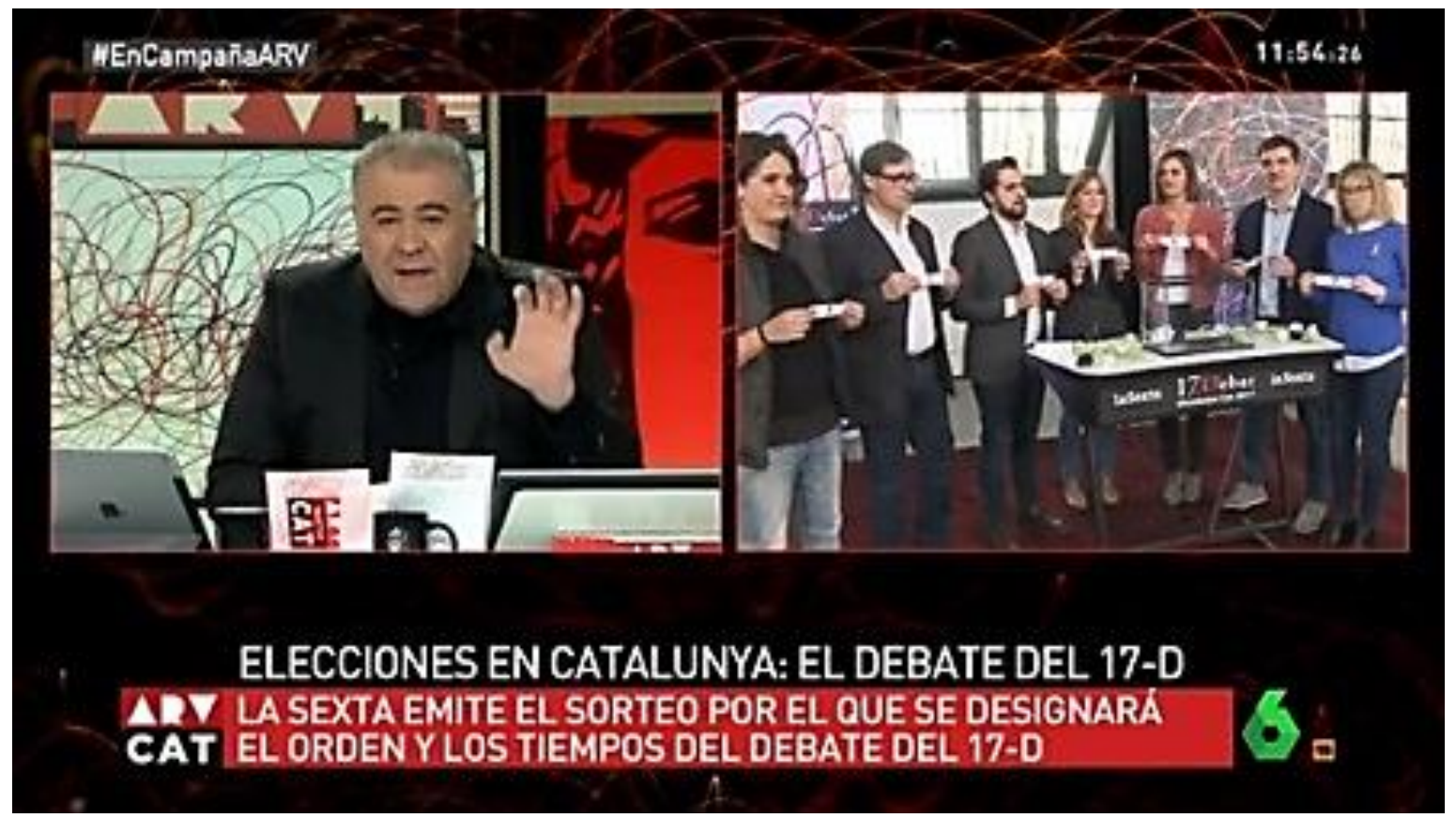

Fuente: lasexta.com (https://goo.gl/ADQ6Ze)

La Sexta Noche, espacio híbrido entre el magazine y el talk show político que emite el canal en el prime time de los sábados, dedica buena parte de sus contenidos del 16 de diciembre, a 24 horas de la celebración de El Debat, a hablar de la trascendencia del mismo, de lo decisivo que puede ser, de la importancia de los temas a tratar y, en definitiva, a poner en valor el programa. Nuevamente, se recurre a una conexión en directo con el lugar de celebración del mismo para hablar con Ana Pastor, que ejercerá de moderadora, sobre diversos aspectos formales y mostrar las primeras imágenes del plató creado exprofeso para la ocasión (imagen 5). 
Imagen 5. Directo con Ana Pastor, moderadora de El Debat, en el programa La Sexta Noche del 16 de diciembre de 2017

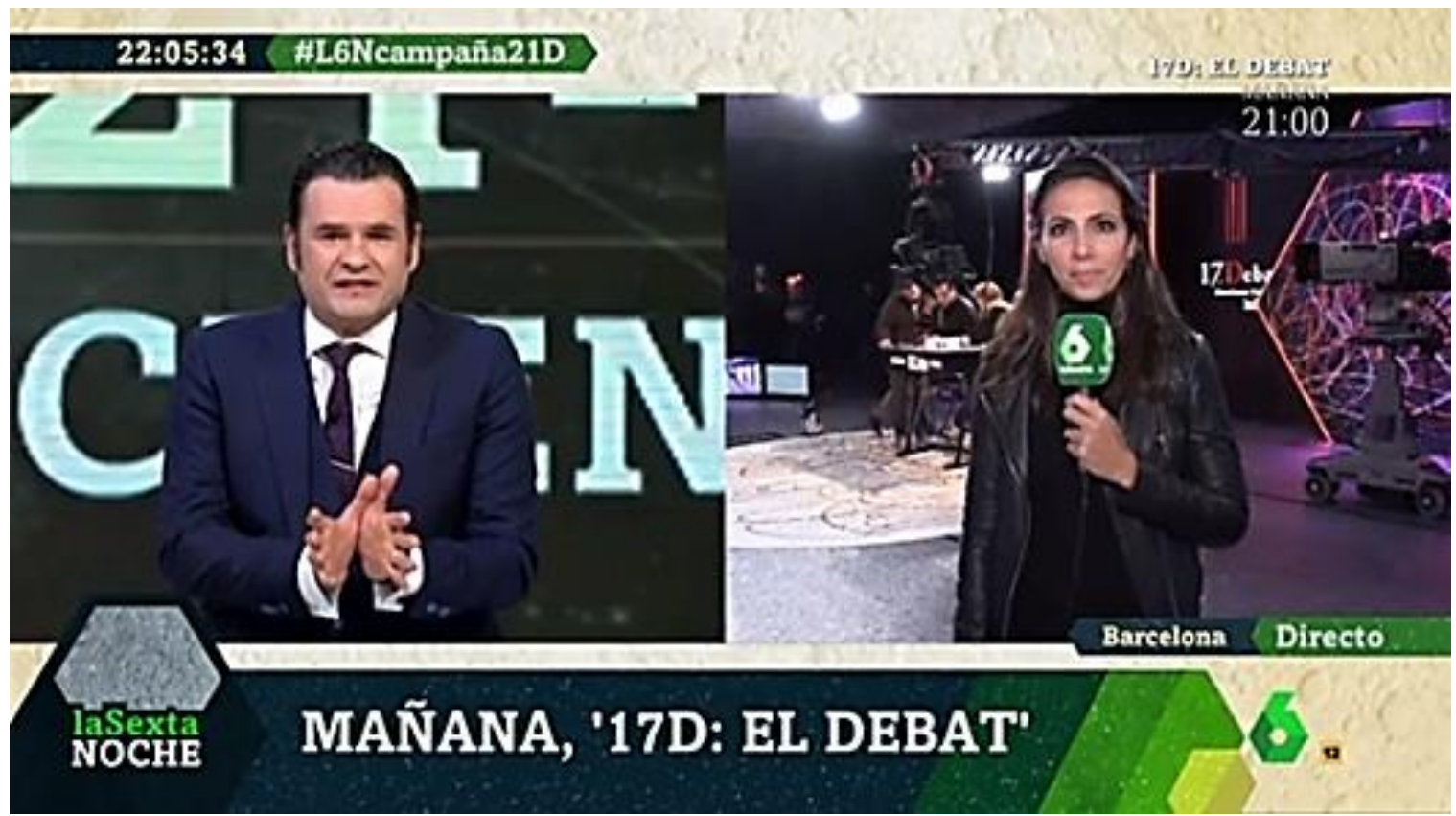

Fuente: lasexta.com (https://goo.gl/wXu2KV)

Imagen 6. Recurso audiovisual dentro de la narrativa transmedia sobre El Debat empleada por La Sexta

laSexta, en su decidida apuesta por la información política, organiza y emite este domingo $17 \mathrm{de}$ diciembre el debate clave en la campaña electoral catalana. Estará moderado por Ana Pastor y se celebrará en Barcelona.

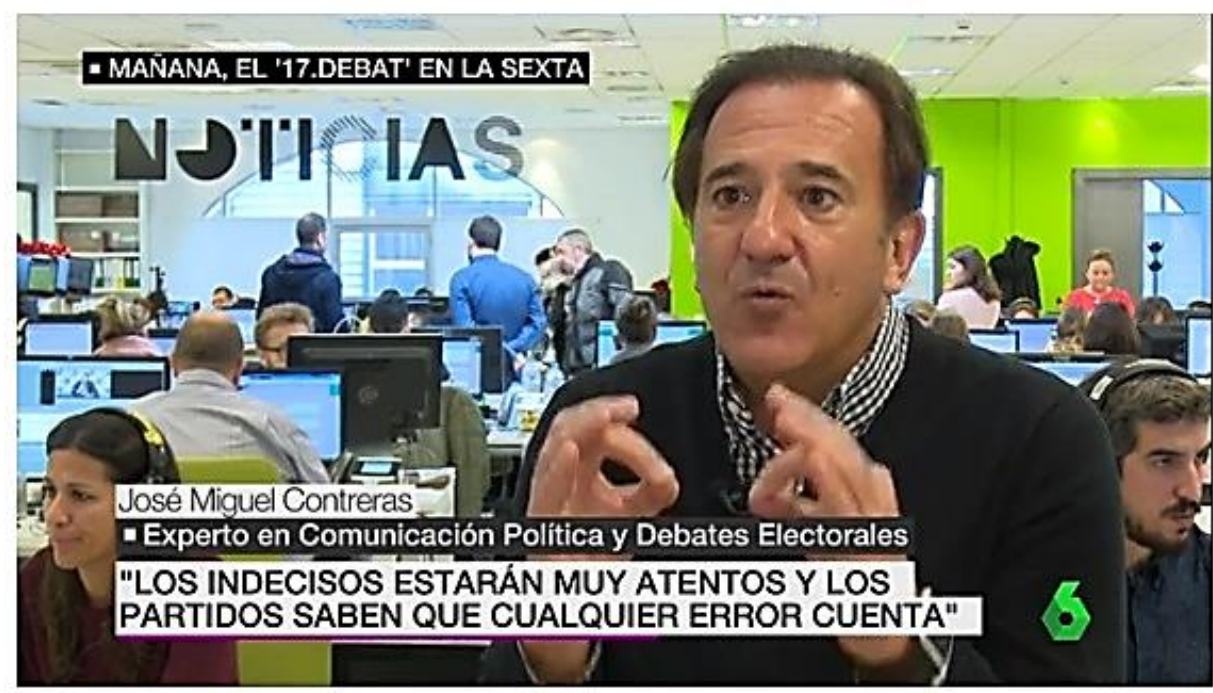

Será un debate a siete entre candidatos de los principales partidos que concurren a las elecciones catalanas del próximo 21 de diciembre: Carles Mundó (ERC), Inés Arrimadas (C's), Josep Rull (JxCat), Miquel Iceta (PSC), Xavier G. Albiol (PPC), Xavi Domenech (CeC) y Vidal Aragonés (CUP).

Fuente: lasexta.com (https://goo.gl/wYBzkr) 
Finalmente, en relación con la página web de la cadena y la información sobre el debate, destaca la apuesta transmedia

(https://goo.gl/wYBzkr) de La Sexta, pues en su portal corporativo no sólo se recurre a información escrita, sino que es posible encontrar todo tipo de informaciones complementarias, bien mediante hipervínculos, bien mediante soporte audiovisual, fundamentalmente vídeo, de espacios de diferentes programas de la cadena en los que se han tratado diversos aspectos de interés del debate, como los servicios informativos (https://goo.gl/pJznpF) o declaraciones de expertos en comunicación política y ciencias afines que ponen nuevamente en valor el debate emitido por La Sexta (imagen 6).

\subsection{Televisió de Catalunya}

La corporación pública catalana emite el último de los debates programados en esta campaña electoral, a través de su principal canal, TV 3, Catalunya Rádio y 324.cat, el portal de información de Televisiò de Catalunya. Obviamente, se emite desde Cataluña y el programa discurre en catalán.

Imagen 7. Spot autopromocional del debate organizado por Televisió de Catalunya

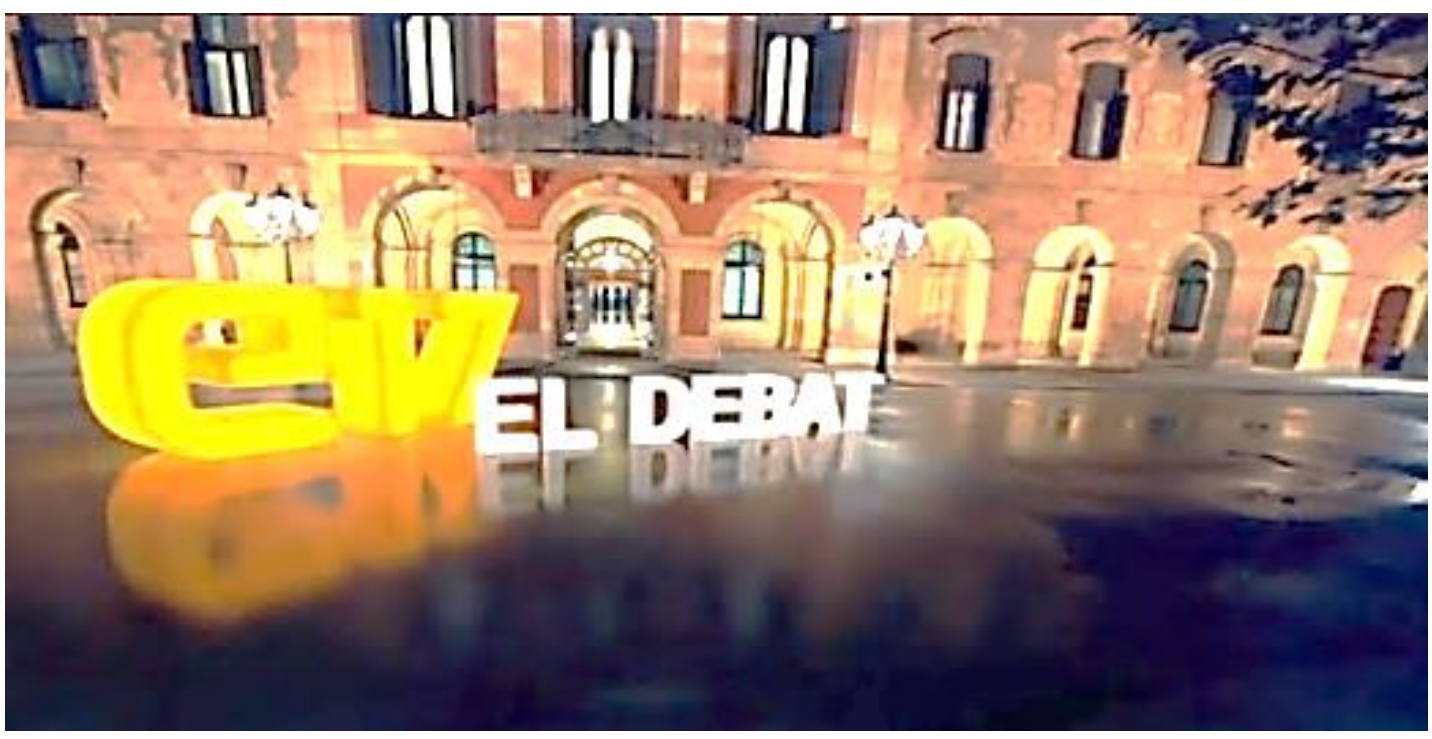

Fuente: ccma.cat (https://goo.gl/9wSY1m)

El spot de autopromoción empleado por TV3 (imagen 7) tiene una duración de 27 segundos y, al igual que La Sexta, singulariza el programa recurriendo a un artículo determinado, El Debat y recurre 
también desde el punto de vista formal, a una ambientación sonora que recuerda al cine épico (https://goo.gl/9wSY1m), acompañada de adjetivos en la voz en off como "decisivo", "extraordinario", "gran debate", etc.

Pese a lo comentado en el párrafo anterior, el spot de TV3 podría encuadrarse dentro del tipo institucional o clásico ya apuntado para TVE, pues las imágenes que componen su discurso narrativo son planos neutros del Parlament de Cataluña, del logotipo institucional de las elecciones, imágenes del presentador, de los políticos que participarán en el debate, etc. Tan sólo de los tonos amarillos, color símbolo del independentismo catalán, que predomina en casi todos los planos y el grafismo, podría intuirse una cierta falta de neutralidad, pero también es cierto que, junto con el rojo, es el color de los símbolos institucionales de Cataluña.

Imagen 8. Colas en el informativo de TV3 sobre la celebración del debate electoral

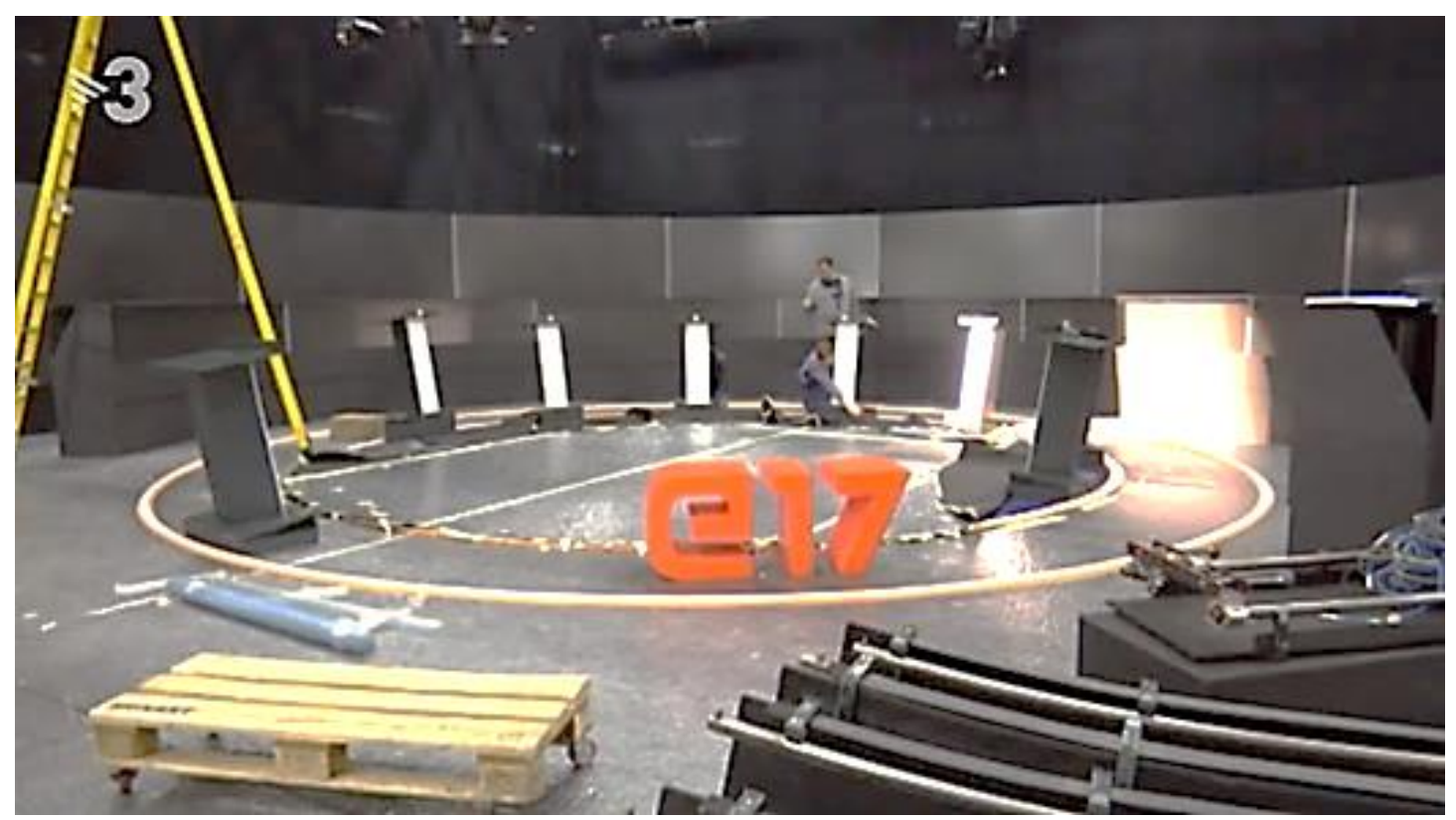

Fuente: ccma.cat (https://goo.gl/U2j2En)

Los informativos de TV3, al igual que ocurre con las otras dos televisiones estudiadas, incluyen contenidos relacionados con el debate, que sirven de autopromoción del mismo (https://goo.gl/U2j2En / 17'25'), aunque este caso destaca por su 
tratamiento secundario, en forma de colas (30 segundos) tras otra noticia sobre el hecho de tener que votar en una jornada laborable y recurriendo simplemente a una voz en off que, sobre planos de recurso del plató, recuerda el día y hora de emisión, además de los temas a tratar y el nombre del presentador; es decir, no existe como tal una noticia específica sobre el debate, ni tan siquiera en el informativo del día de emisión del mismo.

Por último, en relación con el portal web de Televisió de Catalunya, en este caso, como en los anteriores, existe contenido relacionado con el debate, concretamente una noticia (https://goo.gl/guf8Ai), que incluye el spot antes comentado y recuerda los principales aspectos formales y de contenido, junto con la actitud de neutralidad por la que apuesta el canal y la principal novedad de este programa, preguntas de diversas organizaciones sociales a los candidatos de ideología opuesta a la que dichas entidades defienden.

\section{En conclusión: la autopromoción permanente}

Como cabría esperar, los tres canales de televisión analizados apuestan por la autopromoción de los debates electorales que organizan. Recurren para ello a tres acciones principalmente: el spot, la conversión en noticia tanto de la emisión del debate como de diversos aspectos organizativos previos, que generan contenido para los informativos y, en algunos casos, para otros programas de la cadena y, finalmente, la difusión de información sobre el debate a través de las respectivas páginas web.

Aun así, se observan diferencias notables entre cadenas, tanto en el contenido y forma de los debates, como específicamente, en las estrategias de promoción del programa. En relación con esto último, los dos operadores públicos (RTVE y Televisió de Catalunya) recurren en sus spots a un formato clásico e institucional, sobrio incluso, frente a un tratamiento más claramente publicitario o emocional de La Sexta. Las televisiones públicas se limitan a hablar de candidatos y aspectos formales de emisión sobre planos de plató y entornos neutros, institucionales, mientras que la privada apuesta por visualizar la calle, la gente, la actualidad, como un contenido más de la oferta de 
infoentretenimiento del canal, hasta el punto de que se convierte el debate en espectáculo, en un programa de televisión reconocible según los códigos de la noticia, la actualidad, pero también del entretenimiento en televisión.

Esto tiene un cierto reflejo también en los servicios informativos de cada canal, pues La Sexta dedica más tiempo, espacio y recursos que las otras dos a singularizar y resaltar la importancia de su debate. En todo caso, la gran diferencia en relación a la autopromoción a través de los informativos se observa entre las dos televisiones nacionales y la autonómica, pues las dos primeras le dan entidad de noticia propia, específica, dentro del informativo a la celebración del debate y la segunda opta por unas simples colas, como ya se ha dicho.

En todo caso, la principal novedad y diferenciación en cuanto a las estrategias de autopromoción radica, de acuerdo también con el formato de programa diferente por el que apuesta, en la autopromoción intensiva que hace La Sexta de su debate, valiéndose no sólo del spot, el portal web o sus servicios informativos, sino de prácticamente todos los espacios de la cadena, especialmente de aquellos vinculados al infoentretenimiento, apuesta central de la programación de este canal de Atresmedia.

Puede concluirse, por tanto, que el concepto de campaña permanente (Blumenthal, 1980) trasciende el ámbito de la comunicación electoral partidaria o gubernamental y contagia también a las estrategias de autopromoción de las televisiones, dando una importancia capital a las mismas, en línea con las estrategias, por ejemplo, de grandes empresas de otros ámbitos (Fernández-Souto, Puentes-Rivera y Vázquez-Gestal, 2019).

\section{Bibliografía}

Bassat, L. (2008). Confesiones personales de un publicitario. Barcelona: Crítica.

Benoit, W. L., Brazeal, L. M. (2002). "A Functional Analysis of the 1988 Bush-Dukakis Presidential Debates". Argumentation and Advocacy, 38(4), 219-233. 
Blumenthal, S. (1980). The Permanent Campaign. Boston: Beacon Press. Campo Vidal, M. (2017). La cara oculta de los debates electorales. Barcelona: Arpa Editores.

Cantavella Blasco, J. C., Bullough, R., Curiel Calleja, L. A., BlancoSieger, B. M., Mejía Chiang, C. y Pittaro, E. (2008). "Algunos aspectos lingüísticos de los debates electorales Zapatero-Rajoy 2008". Estudios sobre el mensaje periodístico, 14, 79-98. Disponible en:

http://revistas.ucm.es/index.php/ESMP/article/view/ESMP 0808110079A/11822

Fernández-Souto, A. B., Puentes-Rivera, I. y Vázquez-Gestal, M. (2019). "La gestión comunicativa de las grandes empresas en España: estructura, recursos y principales retos de sus responsables". Communication \& Society, 32(1), 161-177.

Hernández Martínez, C. (1999). Manual de Creatividad Publicitaria. Madrid: Síntesis.

López-López, P. C., Puentes-Rivera, I. y Rúas-Araújo, J. (2016). “La comunicación política en las elecciones gallegas del 25 de septiembre de 2016: la agenda temática en el debate de la TVG”. En Herrero Gutiérrez F.J. y Mateos Martín C. (Coords.), Del verbo al bit (1431-1460). La Laguna, Tenerife: Universidad de La Laguna y Sociedad Latina de Comunicación Social.

López-López, P. C., Puentes-Rivera, I. y Rúas-Araújo, J. (2017). "Transparencia en televisiones públicas: desarrollo de indicadores y análisis de los casos de España y Chile". Revista Latina de Comunicación Social, 72, 253-272.

Montañés García, F. (2017). "Una visión de la industria publicitaria actual. En. Perlado Lamo de Espinosa, M., Toledano CuervasMons, F. y Miguel San Emeterio, B. (coords.), El creativo publicitario en la era digital. Nuevos roles y destrezas profesionales (1734). Madrid: Síntesis. Disponible:

https://www.sintesis.com/data/indices/9788491710677.pdf

Ogilvy, D. (1990). Anotaciones privadas de David Ogilyy. Barcelona: Folio. Ogilvy, D. (1994). Ogilvy y la publicidad. Barcelona: Folio.

Quintas, E. y Quintas, N. (2010). "Cara a cara electoral televisado. Análisis audiovisual de los debates entre los candidatos a la presidencia española". Miguel Hernández Communication Journal, 2, 20-39. Disponible en: 
http:/ / rev.innovacionumh.es/index.php?journal=mhcj\&page $=$ article\&op $=$ view\&path $\% 5 \mathrm{~B} \% 5 \mathrm{D}=15 \&$ path $\% 5 \mathrm{~B} \% 5 \mathrm{D}=0$

Rúas-Araújo, J. y García-Sanz, F. J. (2018). Persuasión y neurociencias. Apelar al cerebro. Salamanca: Comunicación Social Ediciones y Publicaciones.

Santiago, R. (2016, junio 12). Debates electorales: los medios mandan. El Mundo. Disponible en:

http://www.elmundo.es/television/2016/06/12/57569a3a468 aeb6b248b45ac.html

\section{Reconocimiento de la investigación}

Esta investigación forma parte de los trabajos desarrollados en el seno del proyecto de investigación (Retos $\mathrm{I}+\mathrm{D}+\mathrm{I}$ ) "DEBATv, Debates Electorales Televisados en España: Modelos, Proceso, Diagnostico y Propuesta" (CSO2017-83159-R), financiado por el Ministerio de Ciencia, Innovación y Universidades y la Agencia Estatal de Investigación (AEI) del Gobierno de España, además del Fondo Europeo de Desarrollo Regional (FEDER) de la Unión Europea (UE). Deriva también de investigaciones previas realizadas en XESCOM: Red Internacional de Investigación de la Gestión de la Comunicación, proyecto de investigación financiado en régimen de concurrencia competitiva por la Consellería de Cultura, Educación e Ordenación Universitaria de la Xunta de Galicia (ED341D R2016/019). 


\title{
Primarias, ¿para qué?: la imagen de los candidatos del PSOE en los medios
}

\author{
Erica Conde-Vázquez \\ Universidade de Vigo
}

\begin{abstract}
PARA CITAR: Conde-Vázquez, É. (2019). "Primarias ¿para qué?: la imagen de los candidatos del PSOE en los medios". En Conde-Vázquez, E., Fontenla-Pedreira, J. y Rúas-Araújo, J. (Eds.), Debates electorales televisados: del antes al después (pp. 193-212). Cuadernos Artesanos de Comunicación, cac154. La Laguna (Tenerife): Latina. DOI: $10.4185 / \operatorname{cac} 154$
\end{abstract}

\section{Resumen}

Los procesos de elecciones primarias son herramientas de desgaste de los partidos (Boix, 1998) motivado, especialmente, por la realización de debates entre los diferentes candidatos permitiendo que se expongan públicamente diatribas internas. También es una realidad que, en la actualidad, los debates electorales se encuentran en una búsqueda continua de nuevos formatos y medios de difusión (Padilla, 2014). Por ello, con el objetivo de profundizar en la influencia de la prensa en dichos instrumentos se propone analizar el debate electoral de las elecciones primarias del PSOE celebrado el 15 de mayo de 2017 entre los tres candidatos: Pedro Sánchez, Patxi López y Susana Díaz. Así como su repercusión en medios para ver como se ha visto afectada la imagen del partido mediáticamente y la que ha tenido en los ciudadanos comunicativamente. 
La propuesta se realizó mediante un estudio de caso analizando la difusión del debate en dos medios nacionales con líneas editoriales opuestas (El País y El Mundo). Se recoge el estudio de los perfiles de Twitter de los citados medios durante los debates: observando el seguimiento del evento y la creación de contenido: número de tweets de cada publicación, producción de contenido audiovisual, seguimiento en directo, número de tweets por candidato, hashtags, memes, menciones a los candidatos, comentarios de los seguidores, me gusta y retweets. Así mismo, la revisión de su hemeroteca digital durante el mismo periodo de tiempo observando los titulares y realizando un análisis comparativo del seguimiento en el medio digital y en la red social.

Palabras clave: debates electorales, elecciones primarias, PSOE, socialistas

\section{Las elecciones primarias y la imagen de los candidatos}

$\mathrm{L}$

A evolución del desarrollo de la democracia y la reclamación por parte de la ciudadanía de una mayor participación de la ciudadanía en la toma de decisiones y la vida política actual, representada en movimientos sociales como el 15-M o DemocraciaRealYa, han provocado que los partidos políticos españoles hayan tenido que replantearse su estructura, su modelo y su proceso de selección interna. Ello conlleva que, a día de hoy, la mayoría de partidos políticos con representación en el Congreso de los Diputados elija a sus líderes mediante elecciones primarias, otorgando un gran poder y capacidad de decisión a sus bases.

En 1998 se celebraban por primera vez en la historia de la democracia española, unas elecciones primarias para que un partido político seleccionara a su candidato a las elecciones generales. Se produjeron en el seno del Partido Socialista Obrero Español (en adelante, PSOE). Este hecho supuso un gran avance para la democracia participativa ya que depositaba una importante decisión en las bases de una formación política, y por ende, en sus votantes. Pero este mismo hecho generó a su vez que se abriese un debate en los medios de comunicación acerca 
de la legitimidad del proceso, los problemas que generaba, si debía ser un proceso cerrado a las bases o abierto a toda la ciudadanía y, lo más importante, el desgaste que podía llegar a producir en el partido. Tendrían que pasar más de diez años para que se volviese a celebrar otras primarias de tal envergadura.

Unas elecciones primarias no dejan de ser un proceso electoral y como tal conlleva la participación de distintos candidatos con diferentes puntos de vista y la decantación de los votantes por una opción u otra. Además, existe el agravante de que se realizan en el seno de un mismo partido provocando de manera intrínseca la rivalidad y la fractura interna de una organización política. Estas divisiones en el seno del partido sumadas a la exposición mediática de los candidatos y el propio partido durante el proceso, hace que sea casi imposible evitar titulares acerca del tema en cuestión, aireando una problemática que afecta su propia imagen.

En España, en el año 2014, el PSOE recuperó su proceso de elecciones primarias con la celebración de las segundas elecciones primarias cerradas para elegir a su Secretario General. Este sistema había sido ya implantado por el partido a finales de los 90, siendo el primer partido político en España que celebraba unas elecciones internas, cuándo en 1998 celebraron las primeras elecciones primarias directas para elegir candidato a la Moncloa, en donde Josep Borrell salió vencedor.

El balance que se hizo sobre la realización de este proceso fue contemplado de manera muy positiva como un activo político espléndido tanto por la ciudadanía como por la prensa. Se entendió como un símbolo de regeneración democrática y transparencia que permitía la igualdad entre ciudadanos y favorecía el debate y reducía la oligarquía política de la primera etapa de la democracia española tal y como recoge Carlos Boix (1998) en su artículo Elecciones primarias en el PSOE: ventajas, ambigüedades y riesgos. Pero a día de hoy, veinte años después, con los cambios socio-políticos que se han producido en la sociedad y con la normalización del sistema de elección al resto de formaciones políticas españolas, ¿Se siguen percibiendo con la misma positividad? ¿Son evaluadas por la prensa de ese modo? ¿Realmente presentan regeneración democrática? 
Boix cuestiona también esa positividad poniendo encima de la mesa las posiciones enfrentadas entre candidatos que plantean unas primarias y las consecuencias de la competitividad que generan:

-Competencias interna y riesgo de fraccionalización.

-La diferencia entre las promesas políticas hechas a militantes y a votantes, quienes tienen intereses diferentes, y en donde contentar a unos puede suponer no agradar a los otros. Estas promesas residen especialmente en la celebración de debates entre los propios candidatos en dónde más allá de las propuestas políticas planteadas únicamente se reabren heridas internas.

-La ambigüedad programática como mejor estrategia.

- ¿Bajo qué criterios toman las decisiones los votantes? Éstos no siempre basan sus decisiones en el liderazgo de los candidatos, si no que a veces priman otros criterios como las redes clientelares y el amiguismo.

-Pese a que se conciban como un símbolo de democratización en la elección de los líderes es muy factible que se produzca lo contrario ya que una vez gana el líder es el encargado de remodelar la estructura bajo su ojo.

Estas posibles consecuencias a las que se hacía referencia hace dos décadas y a las que se pretendía hacer frente, suponen hoy los principales problemas de la celebración de primarias.

Las elecciones primarias consisten en instrumentos de selección de candidatos y ejecutivas de los partidos políticos que se rigen de manera interna mediante los Estatutos y el Reglamento del propio partido, en este caso el PSOE. Las realizadas en 2014 entre Eduardo Madina y Pedro Sánchez marcaron un punto de inflexión en los procesos internos de la formación política, normalizando el uso de este proceso entre los instrumentos del partido.

El año 2017 marca la eclosión en el uso de este proceso que tiene tantos seguidores como detractores dentro y fuera del propio partido. En este año, el partido socialista vivió su año más convulso después de los resultados alcanzados por el partido en las elecciones generales de 
2016, el cuál llega a su mínimo histórico además de la destitución de su Secretario General por discrepancias internas con los conocidos como "barones" del partido. Una de las causas principales radicaba en si el partido debía abstenerse o no para que el PP pudiese gobernar, lo que llevó a la organización a convocar una Junta Gestora que propondría la celebración de unas nuevas primarias para elegir a su Secretario General. Estas primarias se celebrarían entre Pedro Sánchez, Patxi López y Susana Díaz haciendo evidente en los medios, la ruptura en el propio partido y los enfrentamientos entre los diferentes sectores, así como una gran movilización de los propios afiliados, quienes no dudaron en salir a la calle para defender a su candidato. Esto hechos se pusieron de manifiesto durante toda la campaña, pero especialmente, durante el debate electoral celebrado entre los tres candidatos. El cual originó numerosos titulares en prensa centrándose su repercusión en los conflictos entre candidatos más que en las propuestas de renovación.

Estas elecciones internas pusieron al partido en el foco mediático y originó que se convocasen las primarias más rupturistas hasta el momento. El conflicto socialista llenó, durante un largo periodo de tiempo, titulares y noticias en los distintos medios de comunicación viéndose agravado por el uso de las redes sociales que permitieron a los ciudadanos tener voz mostrando su opinión y que, a la vez, una noticia llegase al instante a miles de personas otorgándoles una mayor magnitud a la cuestión.

Después de la celebración de las elecciones, el 21 de mayo de 2017, la nueva ejecutiva revalidada por Pedro Sánchez, llevó el proceso de primarias a todas las estructuras internas del partido diferenciando entre las primarias que se celebran para elegir a las ejecutivas y las primarias que se realizan para elegir a los candidatos (tanto en las federaciones autonómicas como en las ejecutivas provinciales y locales) llevando al partido a desarrollar más de 60 procesos de primarias en el último año. Con los nuevos estatutos refrendados por las bases en el mes de febrero de 2018, se prevé que la saturación de los procesos de primarias se extienda en el tiempo como mínimo durante este año. 
Cada nuevo proceso de primarias implica como mínimo dos candidatos, con sus diferentes avales y su consiguiente campaña, pudiendo alargarse produciéndose dos vueltas de votaciones en caso de que ninguno de los candidatos obtenga más del 50\% en la primera votación. Lo que lleva a que, pese a estar regidas por el Comité de Garantías del partido, salten a los medios las discrepancias y disputas internas haciendo evidente las rupturas tanto entre los candidatos como a nivel partidista. Haciéndose aún más activo cuando se trata de estructuras locales y repercutiendo en una imagen negativa para la formación de manera que el mismo instrumento de renovación democrática socava la imagen de unidad del partido.

En este mismo sentido, cabe tener en cuenta que la repercusión de estos procesos entre la ciudadanía no es la misma en el año 90 que en 2017. Esto es debido a la democratización de internet, la digitalización de la prensa y el auge del uso de las redes sociales. Todo ello permite un acceso instantáneo a la información y la viralización de los contenidos pudiendo conocer la opinión que despiertan las noticias en los votantes. Ello aumenta los efectos y la repercusión en una imagen poco positiva para la formación

\section{E1 caso del PSOE en el debate de las elecciones primarias a la Secretaría General del partido}

En este trabajo se partió de una revisión bibliográfica acerca de los procesos de primarias de los partidos políticos -atendiendo a la teoría expuesta por Haro (1992)- prestando especial atención a los procesos de primarias que se han realizado en España revisando a Sanz Díaz (2015). Se puso el foco de atención en las primarias del PSOE para aportar un significado concreto a la terminología, ver cómo han evolucionado a lo largo de los años, así como comprobar cuáles han sido sus particularidades teniendo en cuenta los análisis planteados por diferentes autores como Boix (1998), Salazar (2000), Subirats (2015). Se hizo también una exposición acerca de los procesos políticos y la política en las redes sociales, especialmente en Twitter, revisando autores como Sabada y Renduelles (2017), Cristófol y Paniagua (2017), Sánchez Duarte (2014) y Congosto-Martínez (2016). 
Se realizó asimismo un análisis de contenido de diferentes medios de comunicación de prensa escrita. El análisis que se hizo fue el día de la celebración del debate, en concreto, el 15 de mayo del 2017 para las primarias a la secretaría general (celebradas el 21 de mayo de 2017). El debate se realizó entre los tres candidatos: Sánchez, Díaz y López en la sede del partido en Madrid, en la calle Ferraz con una duración de 2 horas y moderado por Carmen del Riego. Se estructuró en 4 bloques: político, económico-social, modelo de partido y petición de voto.

Se analizaron las publicaciones realizadas en El País y El Mundo tanto en su edición digital como en las publicaciones realizadas en su perfil de Twitter a través de un estudio de los comentarios e interacciones generadas.

En cuanto al contenido del análisis se tuvieron en cuenta los siguientes parámetros:

-En la edición digital se hizo un análisis de titulares y contenido de los artículos observando el tratamiento realizado de la información y la existencia de expresiones negativas.

-En los perfiles de Twitter de los periódicos se observó el tratamiento de las noticias y su seguimiento, con especial atención a los comentarios generados por los ciudadanos expresando su opinión.

-Se prestó atención a las noticias sobre el contenido de los diferentes debates realizados por los candidatos analizando el tono de los debates, los comentarios suscitados y los temas tratados, así como el tipo de respuestas.

\subsection{Elecciones primarias: concepto y tipos}

El sistema de elección interna de los partidos (conocido como elecciones primarias) tiene su origen en Estados Unidos a principios del siglo XIX. Primero se realizaban para elegir a los delegados que votaban a los candidatos de los partidos y, posteriormente en 1912, Roosevelt generalizó el proceso a todos los ámbitos institucionales para 
evitar que los dirigentes de los partidos impusiesen a sus candidatos y para dar participación a las bases de los partidos (Haro, 1992: 273).

Al hablar de elecciones primarias se debe tener en cuenta que en los partidos políticos existen tres formas de elección de líderes: en primer lugar, los partidos que solo celebran primarias para elegir a su líder; en segundo lugar, partidos que celebran dos primarias (para elegir a su líder y para elegir a los candidatos) y que en el desarrollo de este documento se comprobará que este es el sistema empleado actualmente por el PSOE; y por último, partidos que no votan en primarias (ni una cosa ni la otra ${ }^{44}$ ) si no que realizan la selección de sus líderes mediante la figura de los compromisarios que actúan como delegados de los votantes.

Además de todo lo anterior es importante conocer que existen dos formas a partir de las que una formación política puede celebrar las primarias: cerradas únicamente a la militancia o abiertas a la militancia, pero también a simpatizantes y a la ciudadanía, quienes pueden votar mediante la inscripción en un censo electoral. En algunos casos, para poder inscribirse en los censos electorales, se requiere una pequeña aportación económica simbólica. ${ }^{45}$

Según expone Richard Haro (1992: 277), las elecciones primarias abiertas presentan una serie de ventajas en la transparencia de los sistemas democráticos:

a) Promueven un mayor interés por la política en la ciudadanía al convertirla en protagonista.

b) Personalizan la elección de los candidatos en ambos sentidos, a candidatos y a los electores

c) Aumenta la participación del electorado en la vida del partido no solo votando en los comicios estatales.

d) Dotan a los partidos de mayor transparencia y credibilidad.

${ }^{44}$ Las primarias del PSOE son un caso raro en Europa https://politica.elpais.com/politica/2017/05/19/actualidad/1495192095_5923 77.html 


\section{Las elecciones primarias en la prensa}

No han sido pocas las disputas tanto internas como externas en torno a la celebración de las elecciones primarias y su repercusión en los medios de comunicación. Los comicios internos provocan que se relegue el aparato del partido a un segundo plano mientras los medios de comunicación son los encargados de la reputación de los candidatos actuando como intermediarios (Salazar, 2000).

Desde el año 1998, el PSOE abrió a sus militantes la posibilidad de que concurriese más de un candidato, con la aprobación (o institucionalización) del proceso de primarias. Desde las elecciones Borrell-Almunia se produjo una polarización en la prensa nacional entre los principales medios de prensa escrita del país: El País y El Mundo. Mientras que El País apoyaba el proceso y lo veía como renovación y regeneración democrática; El Mundo se mostraba en contra de dicho proceso e intentaba lastrar las elecciones en favor de las noticias del PP, reafirmando ambos sus líneas editoriales.

Es importante destacar que el reglamento federal del PSOE -que regula la celebración de este tipo de procedimientos- recoge desde el primer momento de su elaboración que las campañas electorales para las elecciones primarias deben celebrarse:

"Sin perjuicio de la individualidad de la campaña de cada candidatura, todos los actos y acciones que las candidaturas desarrollen dentro de la campaña de información, deberán respetar y garantizar unos criterios básicos de unidad de imagen corporativa del partido. Dichos criterios serán establecidos por el Comité Organizador Federal, bajo la supervisión de la Comisión Federal de Garantías Electorales. En el caso de los procesos de primarias autonómicos, sin perjuicio de las competencias de coordinación y supervisión de la Comisión Federal de Garantías Electorales, la fijación de los criterios y la supervisión ordinaria de los mismos corresponderá al comité organizador regional o de nacionalidad y a la comisión regional o de nacionalidad de garantías electorales, respectivamente." 
De este modo se "garantiza" que exista una equidad en el proceso electoral, para que no se pongan únicamente en relevancia las disputas entre candidatos, y no se abran disputan internas en el seno de la organización. Pero ¿esto siempre se consigue?, ¿las primarias favorecen que se terminen aireando los problemas entre los candidatos en los medios?, ¿inciden negativamente en la imagen del partido? Precisamente es esa relación directa de elecciones primarias del partido con la prensa y la imagen del partido las que se analizarán en el presente documento.

Desde el momento en el que se inició el proceso de primarias saltaron a los medios titulares en los que se cuestionaba el procedimiento, y se hablaba de una posible bicefalia, en la que no coincidiese en la misma persona el Secretario General con el Candidato a la Presidencia del Gobierno y que se diese una rivalidad evidente por el duelo del poder.

Llegado ese punto, autores como Uriarte (1998) ya se cuestionaban la relación e influencia de los medios de comunicación en los procesos políticos y en la imagen que estos mismos proyectaban en la sociedad, tildándolos como principales responsables de la poca confianza que despiertan en los ciudadanos.

Pese a que las informaciones están reguladas por el Comité de Garantías, el cumplimiento de la normativa muchas veces no se respeta. No es raro encontrar procesos celebrados en autonomías en los que se ha filtrado información a los medios, evidenciando así la rivalidad entre candidatos ${ }^{46}$, o incluso haciendo caso omiso de lo que otras personalidades tienen que aportar (es el caso de Miguel Ascón, periodista de La Voz de Ourense quien confirma que "a la hora de celebrar el debate de las primarias de Ourense nadie se puso en contacto con él").

\footnotetext{
${ }^{46}$ En la candidatura del PSPV del año 2014 entre Toni Gaspar y Ximo Puig, pese a los esfuerzos durante campaña por hacer ver que los candidatos iban en el mismo camino, uno de los afines a Toni Gaspar filtró un cartel el último día de campaña a la prensa escrita en dónde se mostraba a los candidatos de Puig en un montaje de un cartel de la película "Caminando entre dinosaurios" haciendo referencia a ese sector del partido.
} 
Tampoco es la primera vez que algunos de los pesos pesados de los partidos se muestran contrarios públicamente con el proceso de primarias. Se produce particularmente en el caso de los barones del partido y presidentes socialistas de comunidades autónomas que ven su poder socavado por el procedimiento y a disposición de la militancia en lugar del partido.

Sin duda, el proceso de primarias más comprometido y de mayor rivalidad entre candidatos que se ha mostrado al público ha sido el correspondiente a las elecciones primarias de 2017 para la Secretaría General, donde era conocido que la candidata Susana Díaz, junto con los barones del partido no estaban de acuerdo con Pedro Sánchez, a quien habían quitado del poder. Durante esa campaña se sucedieron titulares en la prensa relativos al proceso y a la elección del candidato ganador, con las correspondientes reacciones consecuencia del revuelo mediático: "Socialista contra el PSOE"47, "Las primarias del PSOE dividen a sus grupo parlamentario en tres"48 o "Lambán (PSOE) sostiene que hay que trabajar para recuperar los "posibles daños colaterales" del proceso de primarias" ${ }^{29}$.

\subsection{Participación política en la red: Twitter como medio de difusión en los procesos de primarias}

Internet ha cambiado por completo los hábitos de consumo de información en la sociedad y en el caso de la información política no iba a ser de otro modo. Así lo revelan diversos estudios sobre redes sociales como el publicado por IAB y Elogia (2017) dónde se afirma que el $86 \%$ de los internautas de entre 16 y 65 años usan las redes

\footnotetext{
${ }^{47}$ Socialismo contra el PSOE.

https://elpais.com/elpais/2017/05/12/opinion/1494585785_237701.html 1205-2017

${ }^{48}$ Las primarias del PSOE dividen en tres el grupo parlamentario socialista. http://www.lavanguardia.com/politica/20170314/42878828943/primariaspsoe-dividen-tres-grupo-parlamentario-socialista.html 14-03-2017

${ }^{49}$ Lambán sostiene que hay que trabajar para recuperar los posibles daños colaterales del proceso de primarias.

http:/ / www.europapress.es/aragon/noticia-lamban-psoe-sostiene-hay-trabajarrecuperar-posibles-danos-colaterales-proceso-primarias-20171008235747.html 03-10-2017
} 
sociales. Dicho estudio también afirma que los comentarios en dichas redes -valorados positivamente por un $66 \%$ de los usuarios- influyen en la toma de decisiones de uno de cada dos encuestados, cifra que aumenta cada año.

Esto conlleva que los partidos hayan tenido que adaptarse para estar en dónde están los ciudadanos (votantes). En la actualidad, la inexistencia de un perfil de candidato o de partido en redes como Facebook o Twitter supone una pérdida de miles de votos. Tal y como se apunta, las redes sociales permiten un feedback constante con los ciudadanos. Así como, conocer sus reacciones al momento y reforzar la existencia de una campaña permanente, dado que los políticos pueden emitir sus mensajes e ideas de manera constante, manteniendo su actividad más allá del periodo electoral.

El uso de estas herramientas amplia y renueva el compromiso democrático y posibilita el desarrollo de soportes que pueden suplir deficiencias de la actividad política tradicional (Sampedro y SánchezDuarte, 2011). Los ciudadanos más activos afiliados a los partidos políticos ven reforzado su compromiso cívico al encontrar formas más amplias y plenas de participación. Es así que se han convertido en un imprescindible para los nuevos partidos, claros ejemplos son los de partidos como Podemos y Ciudadanos, que establecen como norma obligatoria el empleo de las redes sociales por parte de sus líderes y cargos públicos, siguiendo unas pautas de uso.

Sánchez Duarte (2014) señala que la importancia de la influencia de las redes sociales reside en la crisis de representatividad expresada en términos de desafección política, lo cual demanda la necesidad de unas estructuras partidistas más abiertas a la ciudadanía, con iniciativas de transparencia en su gestión cotidiana y que fomenten formas más amplias de participación interna.

Esta tendencia describe unas estructuras excesivamente rígidas ante prácticas digitales más flexibles y autónomas (Blanco, Sánchez-Duarte y Poletti, 2013). Una apertura de procesos y debates internos y externos 
en la red podría restar capacidad de control a las jerarquías de los partidos en beneficio de su militancia (Cristófol y Paniagua, 2015).

Entre todas las redes sociales, Twitter es la red por excelencia ya que, dada su naturaleza pública, es utilizada como "si se hablara en voz alta para que todo el mundo lo oiga” (Congosto, 2011). Su máximo de 280 caracteres obliga a la concisión y conlleva un factor expansivo que permite que los tweets puedan llegar tan lejos como "quiera la red". Cada usuario tiene una capacidad de propagación proporcional a su número de seguidores (followers), pero el mensaje puede ser retransmitido (RT) por los followers de sus followers sin ninguna limitación. Estas características hacen que Twitter sea una de las mayores fuentes públicas de propagación de la información en tiempo real.

Ya existen estudios que demuestran que las interacciones en Twitter permiten revelar el sentimiento político de los ciudadanos, así como seguir la cobertura de los medios de comunicación, como ocurrirá en este caso.

\subsection{Análisis de las publicaciones de los medios en Twitter}

Durante los dos días que se incluyeron en el periodo de estudio se analizaron un total de veinte tweets de ambos periódicos, ocho de ellos corresponden al diario El Mundo y los doce restantes al El País. La frecuencia de publicación fue de un tweet al día sobre el tema analizado, aunque se producen dos picos de publicación, aumentando el día 15 (fecha de celebración del debate entre los tres candidatos).

En el estudio del periódico El País se desprenden los siguientes datos: seguimiento en directo del debate de los tres candidatos con doce publicaciones al respecto, en las cuales se entrecomillan las intervenciones (seis de ellas pertenecen a Pedro Sánchez, dos a Susana Díaz y tres a Patxi López). Las publicaciones son las siguientes: 
Figura 1. Imagen de las publicaciones en El País bajo el hastag \#debatePSOE

Pedro Sánchez al pedir el voto: "Espero que los otros candidatos respeten el resultado del día 21" \#DebatePSQE

Directo | Debate de las primarias del PSOE

Sigue en directo el cara a cara de Susana Díaz, Rałxi Lópezy Pedro Sánchez 5:05 - 15 max, 2017

López: "Si no arreglamos esto podemos desaparecer. Necesitamos un

secretario general a jornada completa" \#DebatePSQE

Directo | Debate de las primarias del PSOE

Sigue en directo el cara a cara de Susana Díaz, Ratai López y Pedro Sánchez

4:46 - 15 mak 2017

Pedro Sánchez: "Yo estoy en el paro por estar contra la

abstención" \#DebatePSQE

Directo | Debate de las primarias del PSOE

Sigue en directo el cara a cara de Susana Díaz, Ratzi López y Pedro Sánchez 4:25 - 15 mak, 2017

Pedro Sánchez: "Mi vía es la portuguesa y de izquierda y no la de la abstención

al PP" \#DebatePSQE

Directo | Debate de las primarias del PSOE

Sigue en directo el cara a cara de Susana Díz, Ratxi López y Pedro Sánchez $4: 23-15$ mak 2017

Susana Díaz: "Pedro, no puedes esconder tu responsabilidad detrás de los militantes" \#DebatePSQE.

\section{Directo | Debate de las primarias del PSOE}

Sigue en directo el cara a cara de Susana Díaz, Ratai López y Pedro Sánchez 4:20 - 15 maas, 2017

Ratxi López: "Nos enfrentamos entre nosotros y no a la derecha... Aquí no ponemos el 'izquierdómetro" \#DebatePSQE

Directo | Debate de las primarias del PSOE

Sigue en directo el cara a cara de Susana Díaz, Ratxi López y Pedro Sánchez 4:15 - 15 max, 2017

Susana Díaz: "Pedro, tú defiendes lo que te viene bien en cada momento, y por eso das bandazos" \#DebatePSQE Directo | Debate de las primarias del PSOE

Sigue en directo el cara a cara de Susana Díaz, Ratzxi López y Pedro Sánchez 4:10 - 15 maak, 2017

Fuente: Elaboración propia a partir de datos extraídos de www.twitter.es/el_pais/ 
En ellos se recogen los ataques entre los candidatos, concretamente los dirigidos por Patxi López y Susana Díaz hacia Pedro Sánchez con entrecomillados como "Pedro tu problema no soy yo, eres tú" o "Pedro ¿sabes qué es una nación?”. Dichos entrecomillados referidos a Pedro Sánchez, versan sobre la abstención al PP (Pedro Sánchez se postuló en contra y provocó el detonante de las primarias ya que la posición del núcleo duro del partido era la contraria). Es el único candidato del que se recoge el alegato final del debate en el que se sobreentiende que es el ganador: "Espero que los otros candidatos respeten el resultado del día 21". La temática de las restantes publicaciones (con menos influencia) giraban en torno a la opinión de Iñaki Gabilondo sobre el debate.

Observando los datos de ElMundo, se realiza un seguimiento en directo de las intervenciones de los candidatos en el debate con ocho publicaciones, pero a diferencia del otro diario, no realiza entrecomillados de estas figuras políticas si no que postea videos con los alegatos finales de los tres y dedica dos tweets a dos de ellos: Susana Díaz "Tu problema eres tú, Díaz reprocha a Sánchez como ha ido perdiendo apoyos" y Patxi López "Se ha acabado la broma: López se compromete a cerrar divisiones" mientras que a Sánchez solo le dedican una publicación compartida con Díaz y con una clara orientación: Sánchez echa en cara a Díaz la “abstención” y ella achaca los malos resultados del PSOE a sus "bandazos". A mayores, realizan una encuesta a sus seguidores y lectores sobre quien creen que ganó el debate.

En general, los contenidos de las publicaciones de ambos diarios se centran más en la relación entre candidatos y la ruptura y la división en la que se encuentra el partido que en los proyectos de partido que cada uno de los candidatos presenta. Ese proyecto de partido es el medio y el fin de todo proceso electoral, sin embargo, en este caso el resto de proyectos no existe en las redes de estos periódicos. 
Haciendo una lectura de los comentarios se pueden extraer diferentes conclusiones:

Primero, la decantación entre los dos bandos favoritos (la mayoría de los comentarios tanto positivos como negativos son hacia Pedro Sánchez y Susana Díaz).

Segundo, la buena consideración de Patxi López como político, los comentarios que hay hacia él son inferiores, pero no hay ninguno en clave negativa.

Tercero, la división militancia vs. barones se muestra muy patente en los comentarios de los seguidores con un núcleo duro muy crítico con la candidata andaluza a la que llegan a insultar en varias ocasiones, cosa que no ocurre con Sánchez.

\subsection{Análisis de los titulares en las publicaciones digitales}

En El País disminuyen considerablemente las publicaciones que realizan en su diario digital acerca del debate, ya que solamente publican una crónica del mismo, mientras que en Twitter hacen un seguimiento casi minutado.

Pese a los cuatro bloques del debate que se mencionan en la metodología, los temas protagonistas referidos por el periódico en la crónica dedicada el día posterior fueron los siguientes: abstención a Rajoy, Comité federal del 1 de octubre, relación con Cataluña y su relación con Podemos.

Por su parte, El Mundo el día del debate realizó un mayor número de publicaciones en su Twitter con respecto al diario.

En sus titulares la prensa escrita también deja ver su línea editorial dedicando más espacio a un candidato que a otro, haciendo más hincapié en la fractura (ElMundo) o la unidad (El País) una vez termina el proceso. Hay un candidato que sigue siendo relegado en las noticias publicadas, Patxi López. 
La mayoría de los titulares publicados en ambos periódicos se centran en la división y horas bajas del partido conteniendo palabras como: "desprecio", "posverdad”, "socialistas contra el PSOE”, "superar la división", "votos con sorpresas" y "heridas, terrenos dónde no habrá unidad", "dimisión”, "bandos", "estupidez de los votantes", "asesinato político", "ruptura", "PSOE roto".

\section{Discusión y conclusiones}

Se ha podido demostrar mediante publicaciones en prensa, y tras la lectura de diferentes referentes teóricos como Boix o Sanz Díaz, que el PSOE es un partido pionero en España en cuanto a la democratización de procesos de elección interna, ya que ha sido el primer partido en celebrar unas elecciones primarias para elegir al candidato a presidente del Gobierno, en 1998, y el primero en celebrar unas primarias para elegir a su secretario general, en el año 2014, así como pionero en celebrar debates internos.

Sin embargo, a pesar de ser una herramienta democrática regida por las mismas normas que se emplean en las elecciones institucionales no deja de carecer de la madurez necesaria planteando más luces que sombras al no cumplirse todavía un año de su implantación.

En cuanto al posicionamiento a favor o en contra de uno u otro candidato, tanto el periódico El Mundo como El País se posicionaban claramente a favor de Susana Díaz. Además, ambas publicaciones se sirvieron a los favoritos (Díaz y Sánchez), dejando relegado al candidato Patxi López al que solo dedicaron un par de titulares en la prensa digital y en Twitter solo lo mencionan durante el debate dedicando menos de la mitad de publicaciones que a sus compañeros.

Por otro lado, tras el estudio documental y el análisis de datos extraídos de la prensa, se confirma que el modelo actual de primarias del PSOE es proclive a ocasionar la ruptura interna del partido. Se ha demostrado que unas elecciones primarias implican siempre más de una posición por la que decantarse. Según el modelo actual de elecciones primarias 
del partido, en el momento que se realizan los comicios internos y se vota a un nuevo secretario general o candidato institucional, los representantes del partido que se encuentran en las cámaras institucionales, véase el caso de parlamentarios y senadores, pueden ser personas diferentes, elegidas años antes y que no tiene por qué seguir la línea de trabajo de los nuevos mandatarios.

Esto provoca bicefalias y tensiones entre ambas personalidades convirtiéndose en vox pópuli y conllevan a dimisiones de diferentes implicados en el proceso (como ocurrió en el 2017 tras la elección de Pedro Sánchez). A pesar de ello, cabe tener en cuenta que en este sentido influye también la capacidad de liderazgo inherente en el secretario/candidato electo y su poder para presentar un buen proyecto que elimine las disensiones que se puedan producir.

Se ha visto durante el análisis de contenido que los diarios inciden en la ruptura y la fragmentación del partido y señalan de forma directa las disputas y rifirrafes internos entre candidatos. Estos hechos terminan llegando a la opinión pública, mediante comentarios en las redes sociales (se han observado diversos comentarios nombrando la fractura del partido y posicionándolo como un partido líder en generar rupturas). Del total de publicaciones analizadas, más del 70\% mencionan el proceso de un modo negativo. Sobre todo, durante los debates, son los propios candidatos quienes ayudan a incidir en este aspecto, mencionando los problemas que tienen con sus compañeros, en vez de centrarse en su proyecto para el partido.

Se ha observado mediante el análisis de los comentarios de las publicaciones que dicha influencia periodística genera debate entre los seguidores de los medios y los votantes, pero también con el propio medio de comunicación, abriendo nuevas vías de discusión con temas paralelos o que a priori estarían en un segundo plano.

Las publicaciones emitidas durante los debates también permiten generar conversación entre los seguidores, que se postulan a favor de 
uno u otro candidato, polarizando los comentarios en dos sentidos: por un lado, manifiestan un profundo rechazo hacia Pedro Sánchez, tildándolo de llevar al partido a un hundimiento profundo y, por otro mostrando un intenso rechazo hacia Susana Díaz, con una mayoría de comentarios que se refieren a ella en tono de insulto.

\section{Bibliografía}

Blanco, V., Duarte, J., y Poletti, M. (2013). “Ciudadanía y tecnopolítica electoral. Ideales y límites burocráticos a la participación digital". Revista Co-herencia, 10(18), 105-137.

Boix, C. (1998). "Elecciones primarias en el PSOE: Ventajas, ambigüedades y riesgos". Claves de razón práctica, 83, 34-38.

Congosto, M., Fernández, M., y Moro, E. (2011). Twitter y política: información, opinión y ¿predicción? Madrid: Universidad Carlos III de Madrid.

Cristófol, C. y Paniagua, J. (2014). "Los candidatos a las primarias del PSOE”. En González-Vallés, J. E. y Valderrama, M. (coord.), Facebook. Análisis de los contenidos compartidos e interacción. Comunicación actual: redes sociales y lo 2.0 y 3.0 153-164.

Haro, R. (1992). "Elecciones primarias abiertas. Aportes para una mayor democratización del sistema político". Revista de Estudios Políticos, 78.

Llaneras, K. (2017). "Las primarias del PSOE son un caso raro en Europa". En El País. Disponible en: https://politica.elpais.com/politica/2017/05/19/actualidad/14 95192095_592377.html.Recuperado el 15/05/2018.

Martín, J. (2017). "Socialismo contra el PSOE”. En El País.

Disponible en: https://elpais.com/elpais/2017/05/12/opinion/1494585785_2 37701.html .Recuperado el 4/06/2018.

Merino, J (2017). "Las primarias del PSOE dividen en tres el grupo parlamentario socialista". En La Vanguardia. Disponible en: http://www.lavanguardia.com/politica/20170314/4287882894 
3/primarias-psoe-dividen-tres-grupo-parlamentariosocialista.html 14-03-2017. Recuperado el 10/6/2018

Sabada, I. y Rendueles, C. (2014). "La hipótesis ciberpolítica: una aproximación crítica". Documentación social, 173, 95-116.

Salazar, O. (2000). "Las primarias socialistas: una experiencia de democratización de la selección de candidatos". Teoría y realidad constitucional, 135-162.

Sánchez Duarte, J. (2014). "Participación digital en los partidos políticos. Autonomía y prácticas de militancia en red". Dígitos: Revista de Comunicación Digital, 1, 59-70.

Subirats, J. (2015). "Todo se mueve. Acción colectiva, acción conectiva. Movimientos, partidos e instituciones". RES. Revista Española de Sociologia, 24, 123-131.

Tapia, I. (2016). “¿Unas primarias a la francesa en el PSOE?” En El Confidencial. Diponible en:

https://blogs.elconfidencial.com/espana/desde-fuera/2016-1222/unas-primarias-a-la-francesa-en-el-psoe_1307741/ Recuperado el 15/05/2018

Uriarte, E. (2001). "La crisis de la imagen de la política y de los políticos y la responsabilidad de los medios de comunicación". Revista de estudios políticos, 111, 45- 64.

\section{Reconocimiento de la investigación}

Este capítulo forma parte de los trabajos desarrollados en el marco del proyecto de I+D+I (Retos) "DEBATv, Debates Electorales Televisados en España: Modelos, Proceso, Diagnostico y Propuesta" (Ref. CSO2017-83159-R), financiado por el Ministerio de Economía, Industria y Competitividad (MINECO), la Agencia Estatal de Investigación (AEI) y el Fondo Europeo de Desarrollo Regional (FEDER) de la Unión Europea (UE). 


\title{
De Escocia a Cataluña: el debate de la independencia, en las redes sociales
}

\author{
Casandra López Marcos \\ CES Next- Universitat de Lleida
}

\begin{abstract}
PARA CITAR: López Marcos, C. (2019). "De Escocia a Cataluña: el debate de la independencia en las redes sociales". En Conde-Vázquez, E., Fontenla-Pedreira, J. y Rúas-Araújo, J. (Eds.), Debates electorales televisados: del antes al después (pp. 213-232). Cuadernos Artesanos de Comunicación, cac 154. La Laguna (Tenerife): Latina. DOI: 10.4185/cac154
\end{abstract}

\section{Resumen}

En 2008 los medios de comunicación tomaron conciencia de la importancia de estar presentes en las redes sociales con el fin de establecer contacto con sus usuarios (Emmett, 2009; Noguera, 2010). El paso decisivo y definitivo se dio en 2007, cuando Facebook abrió su plataforma de software para los medios y los desarrolladores de aplicaciones, lo que permitió a cualquier sector (empresas de juegos, investigadores en las universidades, medios de comunicación) tener la capacidad de lanzar desde Facebook páginas de noticias y enlaces que redirigían a sus propios sitios web (Emmet, 2009). Esta estrategia continuó en Twitter entre 2009 y 2010. "Una organización de noticias sin una cuenta de Twitter era una rara excepción en 2010", según observan en su estudio Messner et al. (2011). Mangold y Faulds (2009: 364) consideran que antes de la aparición de las redes sociales, la forma en que las empresas solían enviar un mensaje a la audiencia era diferente: "La organización y sus agentes desarrollaban el mensaje y lo 
transmitían a sus consumidores potenciales, que podían o no estar dispuestos a participar en el proceso de comunicación”.

En esta investigación se debate y analiza el uso de las redes sociales por parte de los medios de comunicación a propósito del referéndum escocés y de la consulta soberanista catalana.

Palabras clave: redes sociales, Facebook, Twitter, política, independentismo.

\section{Introducción}

— $\mathrm{N}$ los 'viejos tiempos', donde no había ni internet ni redes 1 sociales, los medios de comunicación no podían proporcionar un sistema de comunicación en tiempo real que permitiera disponer de información de forma instantánea; y, por supuesto, el público no podía contactar con los medios de comunicación de manera rápida y fácil. En esa época, el mensaje circulaba en una única dirección: básicamente, los medios emitían un mensaje a través de su propio canal y los usuarios lo recibían.

Si los usuarios querían decir algo al respecto, interactuaban con otros usuarios o trataban de ponerse en contacto con los medios de comunicación mediante el envío de cartas o de manera telefónica (Canga, 2001). Sin embargo, el nuevo entorno tecnológico y la plataforma digital, en la que una parte significativa del público se encuentra actualmente, representan un cambio de paradigma. Hoy en día, hay varias posibilidades a la hora de enviar un mensaje con información referente a hechos de actualidad, y sin los límites del espacio inherentes a las plataformas tradicionales (televisión, radio y prensa), permitiendo al usuario acceder al contenido allí donde esté. Mangold y Faulds (2009: 364) indican que lograr el éxito en esta era "requiere la adopción de un nuevo paradigma de comunicación que reconozca la omnipresencia de la información que ahora se intercambia entre los consumidores mediante las redes sociales". 
Hay que tener en cuenta que las organizaciones informativas suelen estar presentes en las redes sociales de dos maneras: a través de la creación de una red social que pertenece al propio medio, o bien mediante la utilización de las redes sociales preexistentes, tales como Facebook o Twitter (Noguera, 2010).

Un elemento positivo de las redes sociales ajenas y, por tanto, no vinculadas a los medios - como Facebook o Twitter- es el hecho de que son entornos donde la interacción fluye como parte integrante de este espacio digital. Por esta razón, los medios de comunicación utilizan principalmente las redes sociales preexistentes con un triple objetivo interrelacionado: atraer tráfico a su sitio web; lograr y mantener a la audiencia; y mejorar el posicionamiento de su marca (Emmett, 2009; Messner et al 2001; Messner y Medina, 2013; Overholser, 2009; Schulte, 2010; Smith, 2010).

La aparición de las redes sociales entraña una serie de nuevas posibilidades que facilita el trabajo de los periodistas (Campos, 2008; Cerezo, 2008; Lara, 2009; Flores, 2009; Noguera, 2010). Antes de la llegada de las redes sociales, Bardoel y Deuze (2001) ya advirtieron que, en el futuro, el periodismo se vería afectado por los cambios que pudiera traer consigo la nueva tecnología:

"Hemos visto que las nuevas tecnologías de la comunicación y las tendencias de la sociedad civil nos obligan a replantear el periodismo como una profesión de arriba hacia abajo, que solía controlar el 'megáfono' [...]. El periodista ya no funciona en "aislamiento" -sobre todo debido a la gran abundancia de información y el hecho de que el público es perfectamente capaz de acceder a noticias e información por sí mismos [ ...]" (Bardoel y Deuze, 2001).

Siguiendo esta línea, Bardoel y Deuze también sugerían cuál debía ser el papel de los periodistas teniendo en cuenta la tecnología y los cambios que estaba introduciendo: "El periodista del mañana es un profesional que sirve como un nodo en un entorno complejo entre la tecnología y la sociedad, entre las noticias y análisis, entre la anotación y selección, entre la orientación y de investigación" (Bardoel y Deuze, 2001). 
En este sentido, casi una década después, cuando las redes sociales comienzan a estar asentadas, Hermida (2010) subraya una característica de este fenómeno: "Las características estructuradas de micro-blogging están creando nuevas formas de periodismo, lo que muestra una de las formas en las que internet está influyendo en las prácticas periodísticas y, por otra parte, el cambio de cómo el periodismo en sí está definido”. Todos estos cambios implican varias transformaciones en las rutinas periodísticas, lo que significa que los periodistas tienen que asumir nuevas funciones. Rachieva-Stover y Burkett (2012) descubrieron en su investigación que la mayoría de los profesionales de los medios utilizan las redes sociales como una herramienta periodística que permite la búsqueda de información y fuentes; promocionar y difundir las últimas noticias publicadas; $y$, por último, conectar con el lector. Asi $\_$pues, Overholser (2009) justifica el deber del periodista de estar en las redes sociales: "Nuestro trabajo es mantener un ojo en el interés público".

\section{Objetivos e hipótesis}

Para analizar el uso efectivo que los medios están haciendo de las redes sociales se consideró conveniente seleccionar acontecimientos que hubiesen suscitado un alto interés mediático, y previsiblemente, por tanto, una utilización extensiva e intencional de las redes sociales durante el periodo de vigencia de tales acontecimientos. Por ello, se escogieron dos procesos políticos en dos países diferentes: el referéndum escocés (18 de septiembre de 2014) y la consulta soberanista catalana (9 de noviembre de 2014). Estos dos procesos fueron seleccionados por su relevancia y gran impacto en el flujo comunicativo que tuvieron en las redes sociales.

Otro de los motivos para considerar estos dos casos fue el hecho de que son procesos similares y que se suponía que captarían una gran atención mediática. Además, el hecho de escoger dos procesos en dos países diferentes permitía establecer una comparativa del uso de las redes sociales en España y en Reino Unido. 
Con el propósito de determinar el uso de los medios de comunicación en las redes sociales se llevó a cabo un análisis de contenido de los mensajes difundidos en Twitter y Facebook, las redes sociales más populares, acerca del referéndum escocés y de la consulta catalana en una muestra de medios de comunicación españoles y británicos seleccionada en base al ranking establecido por el EGM (España) y el NRS (Reino Unido). Y, en segundo lugar, con el objetivo de conocer la percepción que los propios periodistas tienen sobre los cambios acaecidos en el periodismo, se realizaron una serie de entrevistas en profundidad con periodistas españoles y británicos.

\section{E1 uso mediático de las redes sociales}

Como hemos dicho, el propósito de este estudio es conocer el uso que los medios de comunicación hacen de las redes sociales, recurriendo para ello al caso de dos procesos políticos de alto interés social y mediático: el referéndum escocés y la consulta catalana. Para el diseño de esta investigación se parti del trabajo realizado por García de Torres et al. (2011: 611) sobre el comportamiento periodístico en las redes sociales. En su investigación, estos autores estudiaron, mediante un análisis de contenido, el propósito con el que los periodistas envían mensajes a través de las redes sociales. Atendiendo a los posibles motivos por los que los periodistas pudieran enviar mensajes a través de las cuentas de sus medios de comunicación en Facebook o Twitter, García de Torres et al. (2011: 611) distinguieron los siguientes propósitos: referencial (aquellos mensajes que tienen como objetivo principal compartir un link de enlace - a menudo sobre informaciones publicadas por el medio- y redirigir tráfico a las páginas web de los medios de comunicación); conversacional (promover la interactividad entre los medios y los usuarios); y conativo (pedir a la audiencia que haga algo). Los investigadores llegaron a la conclusión de que tanto Twitter y Facebook son herramientas utilizadas por los medios de comunicación con tres objetivos: redirigir a los usuarios hacia su página web (redirigir tráfico); compartir información; y recibir información.

El trabajo de García de Torres et al. (2011) tiene, sin embargo, algunas limitaciones. En primer lugar, no analizan la temática y el género periodístico de los mensajes, siendo dos elementos que podrían haber 
influido en los resultados finales. Además de que ciertos temas incitan a una mayor "actividad" de la audiencia (es decir, que generan una mayor interacción), hay ciertos formatos periodísticos que captan mejor la atención de la audiencia que otros. En segundo lugar, en el trabajo de García de Torres et al. (2011) no se analiza la reacción del público a los mensajes de los medios. Los usuarios son una parte muy importante en las redes sociales, y se trata, por tanto, de un elemento a tomar en consideración en una investigación de estas características.

A pesar de estas limitaciones, para descubrir el propósito de la emisión de mensajes a través de las redes sociales por parte de los medios, en el diseño de este estudio se ha partido de la categorización de García de Torres et al. (2011). Sin embargo, la categorización que proponen ha sido reconsiderada para hacerla más completa, y, además del propósito de los mensajes, también se ha investigado el tipo de información que los medios comparten.

Teniendo en cuenta estas consideraciones, los objetivos e hipótesis de este estudio sobre el uso de las redes sociales por parte de los medios de comunicación en relación con los procesos catalán y escocés son los siguientes:

Objetivo 1: descubrir el comportamiento de los medios de comunicación a través de su actividad en Facebook y Twitter durante el Referéndum Escocés y la Consulta Soberanista Catalana.

Twitter y Facebook son las redes sociales más populares entre los periodistas y los usuarios. Sin embargo, cada red social tiene sus propias características. Debido a este hecho los medios de comunicación comparten los mensajes de una forma u otra en función de la red social para la que sea el contenido. Esto significa que las empresas de comunicación no se comportan de la misma manera en cada una de las redes sociales analizadas y, obviamente, no comparten el mismo mensaje en Facebook y en Twitter. Tener presencia tanto en Twitter como en Facebook implica desarrollar una estrategia diferente para cada red social, sobre todo en términos de la cantidad de mensajes enviados. 
En Facebook, el envío de una gran cantidad de mensajes, en un corto periodo de tiempo puede conducir a una pérdida de seguidores; sin embargo, esto en Twitter no ocurriría. Twitter es una red más instantánea que Facebook. En un par de minutos esta red social (Twitter) podría haber recibido cientos de mensajes nuevos. Esto es debido a la gran cantidad de mensajes que se comparten en Twitter y la posibilidad que tienen sus usuarios de revisar la actividad de prácticamente cualquier persona con cuenta en Twitter (Arrington, 2006; D'Monte, 2009; Ezumah, 2013: 29). Por el contrario, Facebook no tiene ese carácter tan inmediato y a sus usuarios solo se les permite ver en su página de inicio (timeline de Facebook) los mensajes de algunos de sus contactos, no todos los mensajes y tampoco los de todos sus contactos (Cassidy, 2006; Zhao et al., 2008: 1821).

También debe tenerse en cuenta que, a pesar de sus diferencias, cuando un gran evento tiene lugar las redes sociales cobran un papel importante; especialmente en aquellos vinculados a un proceso político, como es el caso del referéndum escocés o de la consulta catalana (Anderson, 2014; Curtis, 2014; Pedersen et al, 2014; Quinlan et al, 2013: 195). De hecho, puede ocurrir que la actividad de los medios de comunicación aumente con la proximidad del evento. Conforme a estos argumentos, se plantearon las siguientes hipótesis:

H1. Los medios tienden a compartir más mensajes en Twitter que en Facebook.

H2. Cuando tiene lugar un acontecimiento importante (como el referéndum escocés o la consulta soberanista catalana), el número de mensajes sobre ese tema será mayor a medida que se aproxime la fecha del evento.

Se pretende igualmente identificar el propósito (proporcionar noticias, proporcionar opinión, auto- promoción, conativo y conversacional) por el cual los medios de comunicación transmiten un mensaje a través de las redes sociales en cualquiera de los casos estudiados.

Los medios de comunicación utilizan fundamentalmente las redes sociales con el fin de dirigir tráfico a su página web. Logran este 
objetivo mediante mensajes cuya finalidad principal es conectar con su público a través de las redes sociales (Emmet, 2009; Messner et al., 2011, Cappelletti y Domínguez, 2014). En su estudio, García de Torres et al. (2011) descubrieron que en la gran mayoría de las ocasiones los medios comparten mensajes referenciales. Sin embargo, puede ocurrir que cambie el propósito que motiva a los medios de comunicación a compartir un mensaje cuando un asunto de rabiosa actualidad tiene lugar. Pudiera ser que, ante un hecho íntimamente ligado a la actualidad de ese momento, el interés de los medios de comunicación esté más ligado a generar conversación, dada la relevancia del evento. Teniendo en cuenta estos argumentos, se ha considerado la siguiente hipótesis:

H3. En lo relativo al referéndum escocés y la consulta catalana, los medios son más propensos a enviar mensajes con el objetivo de proporcionar noticias y conversación.

Objetivo 2: asimismo, nos proponemos analizar el tipo de información (noticias, entrevistas, reportajes, directo, opinión) que suelen compartir los periodistas en las redes sociales.

Sin duda, el modo en el que se producen las noticias ha cambiado. Esto ha ocurrido como consecuencia de los cambios introducidos en el lenguaje periodístico, en su narrativa y, por supuesto, en la plataforma a través de la que se difunde la información periodística. Las prácticas periodísticas han tenido que adaptarse a los requerimientos del nuevo entorno digital (Jenkins, 2009; Waters et al. 2010; Van der Haak et al.; 2012; D’vorking, 2012; Orihuela, 2012; Scolari, 2013; Linnel, 2014). Así, pues, en este nuevo ecosistema los medios han tenido que seguir ciertas reglas con el objetivo de compartir exitosamente su contenido. Estas reglas puedes resumirse en tres: ser transparente, ser neutral (Kovach y Rosenstiel, 2008; Lasorsa et al., 2012) e invitar a los usuarios a participar en los procesos de producción de las noticias (Phillips, 2010; Karlsson, 2010). El género periodístico que mejor cumple estas reglas es la noticia. Las noticias dan cuenta de lo que ha sucedido en el tono más neutral y transparente posible; y, además de esto, es fácil invitar a la audiencia a participar en el proceso de producción de noticias, por ejemplo, pidiéndoles recursos multimedia que la ilustren. Así, pues, la hipótesis planteada es la siguiente: 
H4. En las redes sociales, los medios suelen compartir noticias en lugar de otro tipo de información.

\section{Método}

Como ya hemos dicho, para este estudio se ha llevado a cabo un análisis de contenido de los mensajes emitidos en las redes sociales Twitter y Facebook por una muestra de medios de comunicación en relación con dos procesos políticos, el referéndum escocés y consulta soberanista catalana. Estos dos procesos fueron seleccionados por su relevancia y gran impacto en el flujo comunicativo de las redes sociales. Otro motivo que justifica la elección de estos dos casos de estudio, es el hecho de que los dos son similares en el sentido de que son procesos políticos que lograron capturar una gran atención mediática.

La muestra está compuesta por un total de 10 medios, seleccionados en base a un criterio geográfico, a su orientación ideológica y la posición que ocupan en las en- cuestas sobre índice de audiencia (EGM y NRS). Los medios escogidos fueron:

Tabla 1. Muestra seleccionada

\begin{tabular}{|l|l|l|}
\hline \multirow{2}{*}{ Asmbito territorial } & Tendencia editorial & \multicolumn{1}{|c|}{ Medios } \\
\hline \multirow{2}{*}{ Reino Unido (sin Escocia) } & Progresista & The Herald \\
\cline { 2 - 3 } & Conservador & The Scotsman \\
\hline \multirow{2}{*}{ Medio de comunicación público británico } & Progresista & The Guardian \\
\cline { 2 - 3 } & Conservador & The Times \\
\hline \multirow{2}{*}{ España (sin Cataluña) } & Neutral & BBC \\
\hline Cataluña & Progresista & El País \\
\cline { 2 - 3 } & Conservador & \multirow{2}{*}{ ABC } \\
\hline \multirow{2}{*}{ Medio de comunicación público español } & Progresista & El Periódico \\
\cline { 2 - 3 } & Conservador & La Vanguardia \\
\hline
\end{tabular}


La recogida de los mensajes enviados por los medios de comunicación seleccionados se realizó en dos periodos de tiempo diferentes, uno para el referéndum escocés y otro para la consulta catalana, pero siguiendo la misma estructura en base al mismo número de semanas de estudio. Se obtuvieron los mensajes emitidos durante las tres semanas previas a aquella en que incluía el día del referéndum o la consulta; los emitidos durante la semana del referéndum o la consulta; y los emitidos durante las dos semanas posteriores. Así pues, la muestra se recopiló en estos periodos:

— Referéndum escocés (18 de septiembre de 2014): muestra del 20 de agosto al 1 de octubre, ambos incluidos.

- Consulta catalana (9 de noviembre de 2014): muestra recogida del 12 de octubre al 23 de noviembre, ambos incluidos.

Para la recopilación de los mensajes enviados a través de Facebook y Twitter se tuvo en cuenta solo aquellos mensajes referentes al referéndum escocés o la consulta catalana. Por tanto, aquellos mensajes referentes a otros asuntos no fueron incluidos en la muestra.

\section{Resultados}

A continuación, se va a exponer los principales resultados y conclusiones extraídas del análisis de contenido. Se analizaron un total de 3.127 mensajes de Twitter y de Facebook con el objetivo de determinar el uso de las redes sociales por parte de los medios de comunicación. En Twitter se recogieron un total de 2.937 mensajes (el 93,92\%), y en Facebook, 190 (el 6,08\%). La tendencia parece evidente: los medios de comunicación prefieren compartir sus informaciones en Twitter antes que en Facebook. En cuanto a los países analizados, los medios de comunicación de Reino Unido tienden a hacer más uso de las redes sociales que los medios de España.

Además, ha quedado probado que cuando tiene lugar un suceso importante aumenta el número de mensajes que se mandan utilizando las redes sociales. 
Tabla 2.

\begin{tabular}{|c|c|}
\hline \multicolumn{2}{|c|}{ Mensajes en medios de Reino Unido (incluyendo Escocia) } \\
\hline Twitter & Facebook \\
\hline $1.920(94,49 \%)$ & $112(5,51 \%)$ \\
\hline \multicolumn{2}{|c|}{ Total: 2.032 mensajes } \\
\hline
\end{tabular}

\begin{tabular}{|c|c|}
\hline \multicolumn{3}{|c|}{ Mensajes en medios de España (incluyendo Cataluña) } \\
\hline Twitter & Facebook \\
\hline $1.017(92,88 \%)$ & $78(7.12 \%)$ \\
\hline \multicolumn{3}{|c|}{ Total: 1.095 mensajes } \\
\hline
\end{tabular}

Los datos analizados muestran que cuanto más próximo estaba el referéndum (en Escocia) o la consulta (en Cataluña), mayor era el número de mensajes que se enviaban sobre estos temas. Este hecho muestra que Twitter y Facebook se ven influidos por las noticias de actualidad. Por tanto, los hechos noticiosos influyen en el flujo comunicativo que circula en las redes sociales. Los medios de comunicación intentan obtener un mayor volumen de audiencia a partir de los acontecimientos importantes (como los dos casos de estudio). Por ello, los medios difunden un mayor número de contenido acerca del evento cuando éste se aproxima. Esto no es algo nuevo, puesto que es uno de los principios tradicionales del periodismo, solo que trasladado al mundo digital.

Gráfico 1: Mensajes de los medios de Reino Unido registrados en Twitter

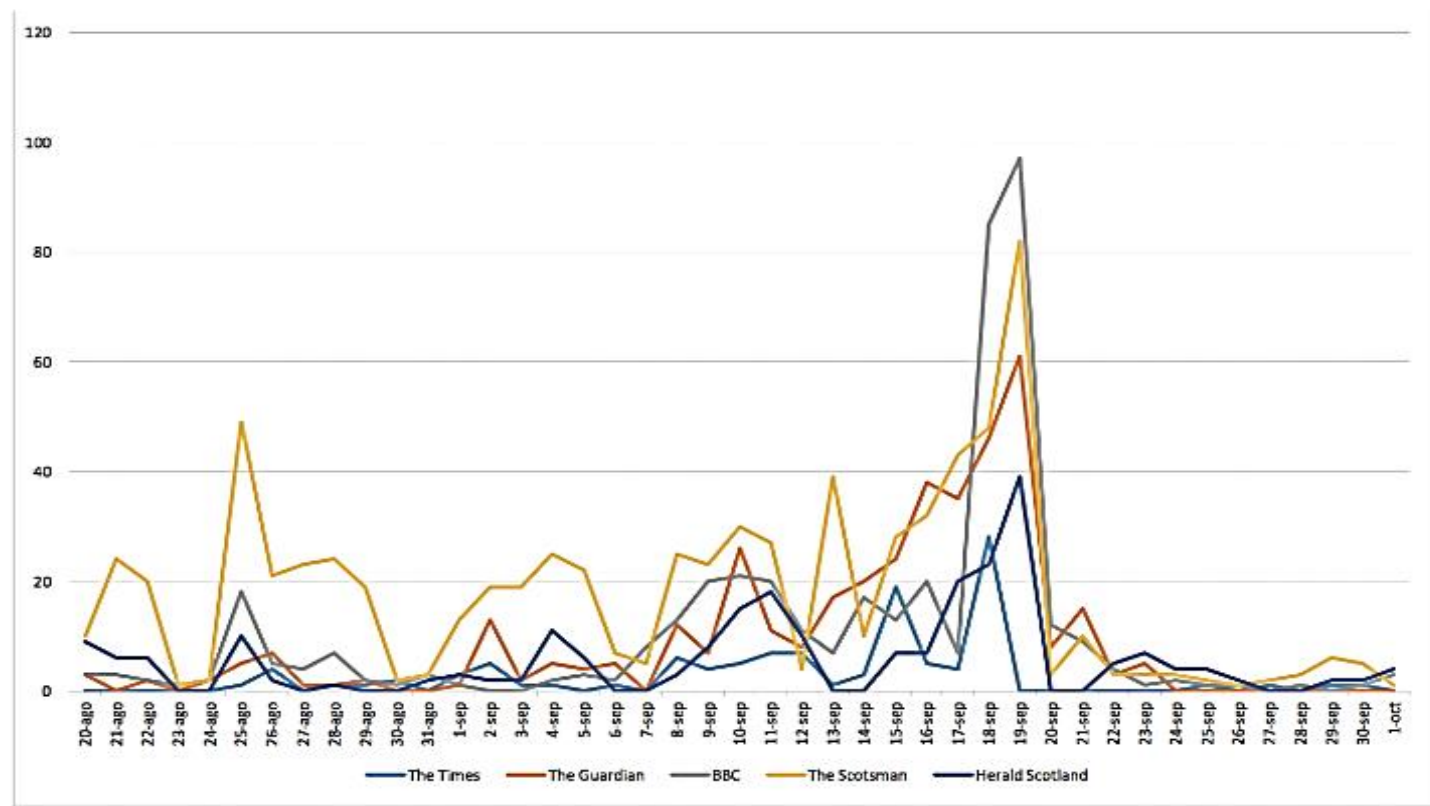


Gráfico 2: Mensajes de los medios de Reino Unido registrados en Facebook

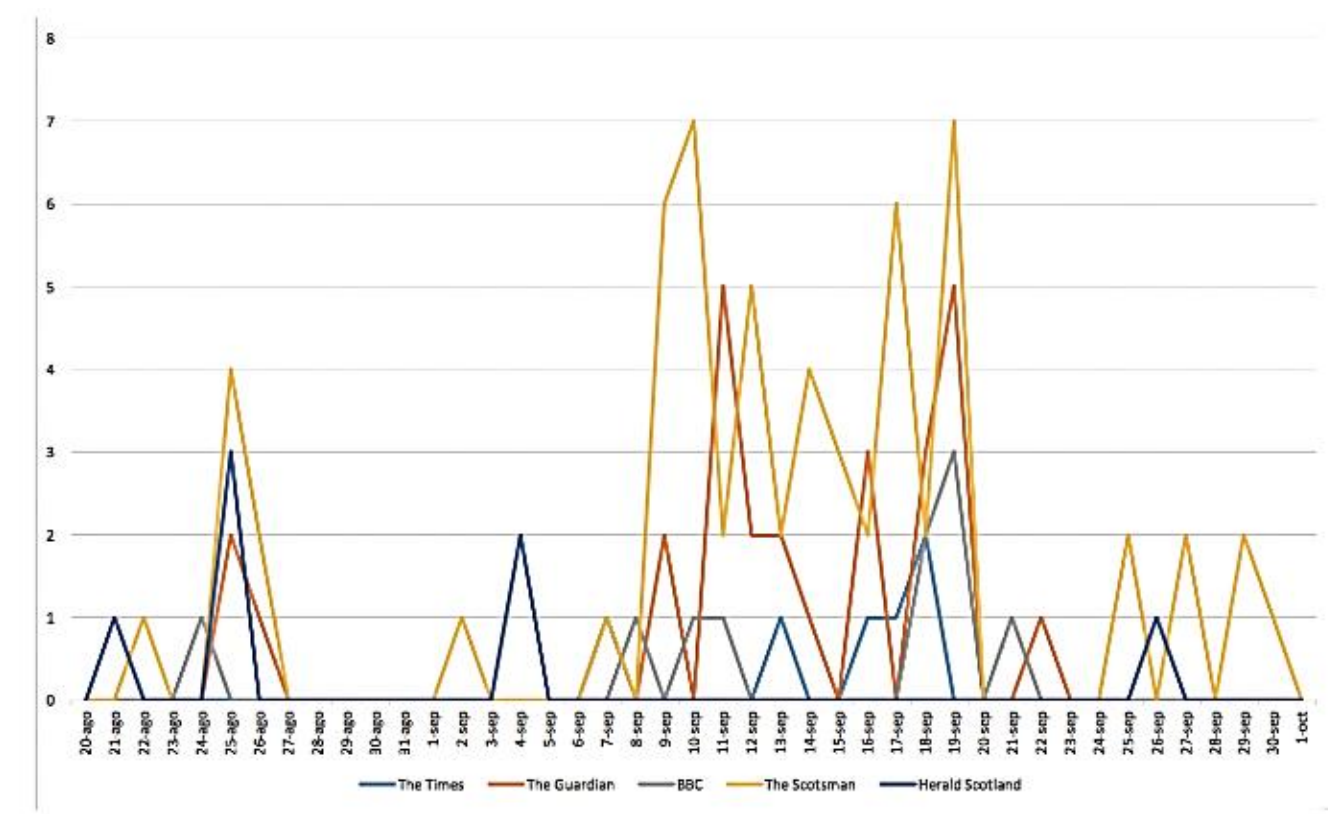

Gráfico 3: Mensajes de los medios de España registrados en Facebook

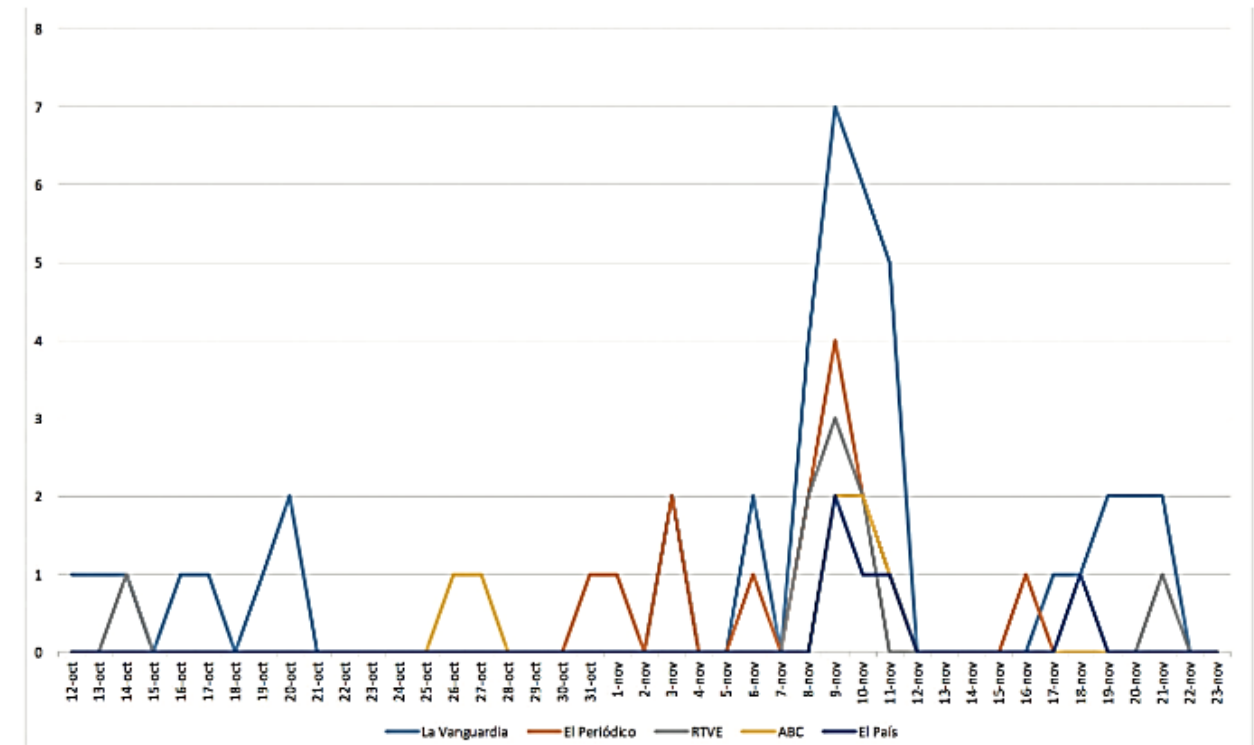

En esta investigación también se identificó el propósito (proporcionar información, proporcionar opinión, autopromocional, conativo o conversacional) con el que el medio de comunicación enviaba mensajes 
a través de las redes. Los resultados obtenidos permiten afirmar que el propósito mayoritario por el que los medios difunden un mensaje es el de proporcionar información. Esto puede ser debido a que este tipo de mensaje tiene un formato adecuado, ya que condensan la información más importante sobre un determinado suceso en pocas palabras. Es sorprendente encontrar que los propósitos conversacionales y proporcionar opinión no alcanzan un porcentaje importante, en particular si consideramos que las redes sociales son plataformas hechas para conversar con otros y compartir opiniones e información. También es llamativo el bajo porcentaje que registran los mensajes autopromocionales.

\section{Tabla 2.}

\begin{tabular}{|c|c|c|c|}
\hline \multicolumn{4}{|c|}{ Propósito de envío de mensajes en Twitter y en Facebook } \\
\hline $\begin{array}{c}\text { Objetivo de } \\
\text { mensajes en } \\
\text { Twitter (Reino } \\
\text { Unido) }\end{array}$ & $\begin{array}{c}\text { Objetivo de } \\
\text { mensajes en } \\
\text { Twitter (España) }\end{array}$ & $\begin{array}{c}\text { Objetivo de } \\
\text { mensajes en } \\
\text { Facebook (Reino } \\
\text { Unido) }\end{array}$ & $\begin{array}{c}\text { Objetivo de } \\
\text { mensajes en } \\
\text { Facebook } \\
\text { (España) }\end{array}$ \\
\hline $\begin{array}{c}\text { Proporcionar } \\
\text { información } \\
(70,26 \%)\end{array}$ & $\begin{array}{l}\text { Proporcionar } \\
\text { información } \\
(82,83 \%)\end{array}$ & $\begin{array}{l}\text { Proporcionar } \\
\text { información } \\
(69,65 \%)\end{array}$ & $\begin{array}{l}\text { Proporcionar } \\
\text { información } \\
(75,64 \%)\end{array}$ \\
\hline $\begin{array}{c}\text { Autopromocional } \\
(24,17 \%)\end{array}$ & $\begin{array}{c}\text { Autopromocional } \\
(12,23 \%)\end{array}$ & $\begin{array}{l}\text { Autopromocional } \\
(20,54 \%)\end{array}$ & $\begin{array}{c}\text { Conversacional } \\
(10,26 \%)\end{array}$ \\
\hline $\begin{array}{c}\text { Conversacional } \\
(3,59 \%) \\
\end{array}$ & $\begin{array}{c}\text { Proporcionar } \\
\text { opinión }(3,03 \%)\end{array}$ & $\begin{array}{c}\text { Proporcionar } \\
\text { opinión }(4,46 \%)\end{array}$ & $\begin{array}{c}\text { Autopromocional } \\
(8,97 \%)\end{array}$ \\
\hline $\begin{array}{c}\text { Proporcionar } \\
\text { opinión }(1,77 \%)\end{array}$ & $\begin{array}{c}\text { Conversacional } \\
(1,68 \%)\end{array}$ & $\begin{array}{c}\text { Conversacional } \\
(4,46 \%)\end{array}$ & $\begin{array}{c}\text { Proporcionar } \\
\text { opinión }(5,13 \%)\end{array}$ \\
\hline Conativo $(0,21 \%)$ & Conativo $(0,22 \%)$ & Conativo $(0,89 \%)$ & -- \\
\hline
\end{tabular}

Otro de los elementos analizados fue el tipo de información (noticias, entrevistas, reportajes, en directo u opinión) publicada en Twitter o Facebook. Aparentemente, este objetivo puede parecer similar al anterior, pero no lo es. Es diferente atender al propósito (proporcionar información, proporcionar opinión, autopromocional, conativo o conversacional) con el que los medios de comunicación comparten mensajes que investigar los tipos de mensajes (noticias, reportajes, entrevistas...) más compartidos. Los resultados indican que los medios de comunicación escogen, en la gran mayoría de las ocasiones, las noticias como el tipo de formato de la información compartida. La media de tiempo que los usuarios pasan leyendo la información a la que han llegado a través de las redes sociales es muy bajo, dado que los usuarios reciben enormes cantidades de información (Gómez- 
Rodríguez et al., 2014; Mislove et al., 2007). Esto pone de manifiesto que en ámbito de las redes sociales las noticias son el formato periodístico que más rápido se produce y se lee.

\section{Tabla 3.}

\begin{tabular}{|c|c|c|c|}
\hline \multicolumn{4}{|c|}{ Tipo de información compartida en Twitter y en Facebook } \\
\hline $\begin{array}{c}\text { Objetivo de } \\
\text { mensajes en Twitter } \\
\text { (Reino Unido) }\end{array}$ & $\begin{array}{c}\text { Objetivo de } \\
\text { mensajes en Twitter } \\
\text { (España) }\end{array}$ & $\begin{array}{l}\text { Objetivo de } \\
\text { mensajes en } \\
\text { Facebook } \\
\text { (Reino Unido) }\end{array}$ & $\begin{array}{c}\text { Objetivo de } \\
\text { mensajes en } \\
\text { Facebook (España) }\end{array}$ \\
\hline Noticias $(76,11 \%)$ & Noticias $(72,53 \%)$ & Noticias $(65,5 \%)$ & Noticias $(65,39 \%)$ \\
\hline Reportajes $(12,62 \%)$ & Directo $(16,20 \%)$ & Reportajes $(24,41 \%)$ & Reportajes $(12,48 \%)$ \\
\hline $\begin{array}{c}\text { Dar opinión } \\
(3,83 \%)\end{array}$ & Reportajes $(4,80 \%)$ & Directo $(4,15 \%)$ & Reportajes $(9,08 \%)$ \\
\hline Directo $(4,10 \%)$ & $\begin{array}{c}\text { Dar opinión } \\
(3,10 \%)\end{array}$ & $\begin{array}{c}\text { Dar opinión } \\
(2,87 \%)\end{array}$ & Directo $(6,86 \%)$ \\
\hline $\begin{array}{c}\text { Pedir opinión } \\
(2,77 \%)\end{array}$ & Entrevistas $(1,73 \%)$ & $\begin{array}{c}\text { Pedir opinión } \\
(3,06 \%)\end{array}$ & $\begin{array}{c}\text { Pedir opinión } \\
(3,33 \%)\end{array}$ \\
\hline Entrevistas $(0,57 \%)$ & $\begin{array}{c}\text { Pedir opinión } \\
(1,64 \%)\end{array}$ & Entrevistas $(0 \%)$ & Entrevistas $(2,86 \%)$ \\
\hline
\end{tabular}

En lo que respecta al lugar de edición del medio, se ha demostrado que la proximidad sigue siendo un valor noticia importante, incluso en la era de las redes sociales. Así, en el caso del referéndum escocés los periódicos editados en Reino Unido difundieron en las redes sociales básicamente información referente al referéndum escocés, y en mucha menor medida información sobre la consulta catalana. Por tanto, este resultado va en consonancia con la idea de proximidad como valor noticia. Así, persiste la práctica periodística de que cuanto más cerca esté el lugar donde se sucede la noticia, mayor será la cobertura mediática que recibirá (López et al., 1998; Shoemaker et al., 2007; Túñez y Guevara, 2009). Sin embargo, es necesario llevar a cabo más estudios que incluyan otros temas que no aborden asuntos políticos para determinar si la proximidad es o no un valor cuando se trata de compartir noticias en las redes sociales.

Por último, aunque se han encontrado ciertas diferencias en el uso de las redes sociales en cada uno de los países analizados, no puede decirse que tales diferencias sean sustanciales. De hecho, en términos generales, puede decirse que hay muchas similitudes entre el uso 
periodístico de las redes sociales entre los medios de Reino Unido y de España.

\section{Conclusiones}

Las redes sociales han revolucionado el periodismo a la vez que ha introducido importantes novedades y cambios en las prácticas periodísticas. En esta investigación se ha abordado cómo las redacciones han introducido en sus rutinas profesionales diarias el trabajo en las redes como forma de conectar con su audiencia. Esta afirmación está en consonancia con la visión de académicos como Emmett (2009), Messner et al. (2011), Mangold y Faulds (2009) o Noguera (2010), quienes subrayan la importancia de tener presencia en las redes sociales para establecer contacto con la audiencia. Además, desde que en 2008 los medios se dieran cuenta de esta posibilidad no han cejado en su empeño de usar las redes, especialmente en Twitter o Facebook, como una forma de enviar mensajes a su audiencia para conectar con ellos, atraer tráfico a su sitio web y fortalecer su marca como medio de comunicación.

En la era anterior a las redes sociales, ni las empresas periodísticas, ni los periodistas prestaban tanta atención a las impresiones y comentarios de los usuarios a propósito de las informaciones que publicaba, debido a la dificultad para obtener un feedback en tiempo real, como sucede con las redes sociales.

Por último, debe tenerse en cuenta que, aunque se han encontrado diferencias menores entre los medios de comunicación de Reino Unido y de España, sería necesario hacer una recogida de muestra mayor y referente a otro tema, que ayude a determinar si realmente hay diferencias notables en cómo se desarrolla el trabajo periodístico en redes sociales en países con culturas periodísticas distintas. 


\section{Bibliografía}

Anderson, S. (2014). "Scottish independence: which issues have led the Twitter debate in 2014?". The Guardian. Disponible en http://www.theguardian.com/news/ datablog/2014/jul/08/scottish-independence-referendumtwitter-analysis-topics- debate-2014

Arrington, M. (2006). "Odeo Releases Twttr", Techcrunch. Disponible en https://techcrunch.com/2006/07/15/is-twttr-interesting/

Bardoel, J. y Deuze, M. (2001). "Network journalism: Converging competences of media professionals and professionalism", Australian Journalism Review, 23 (2), 91-103.

Campos Freire, F. (2008). "Las redes sociales trastocan los modelos de los medios de comunicación tradicionales", Revista Latina de Comunicación Social, 63, 287- 293.

Canga Larequi, J. (2001). "Periodismo e Internet: nuevo medio, vieja profesión”, Estudios sobre el Mensaje Periodístico, 7, 33-48.

Cappelletti Júnior, M. y Domínguez Quintas, S. (2014). "La curaduría de contenidos y la narrativa colaborativa en el Ciberperiodismo: estudio del caso de Storify en el diario digital Elpais.com”. Estudios sobre el Mensaje Periodístico, 20 (1), 17-31.

Carrera Álvarez, P., Sainz de Baranda Andújar, C., Herrero Curiel, E. y Limón Serrano, N. (2012). "Journalism and social media: How Spanish journalists are using Twitter". Estudios sobre el Mensaje Periodístico, 18 (1), 31-53.

Casero Ripollés, A. e Izquierdo Castillo, J. (2013). "Between decline and a new online business model: The case of the Spanish newspaper industry", Journal of Media Business Studies, 10 (1), 6378.

Cerezo, J. M. (2008). "Hacia un nuevo paradigma. La era de la información frag- mentada", Telos. Cuadernos de Comunicación e Innovación, 76, 91-98.

Emmett, A. (2009). "Networking news". American Journalism Review. Disponible en: http://www.ajr.org/Article.asp?id=4646

Ezumah, B. A. (2013). "College students' use of social media: Site preferences, uses and gratifications theory revisited". International Journal of Business and Social Science, 4 (5), 27-34. 
Farrell, M. (2013). "Social media, TV everywhere drive audience", Broadcasting \& Cable, 143(37), 17.

Flores Vivar, J. M. (2009). "Nuevos modelos de comunicación, perfiles y tendencias en las redes sociales", Comunicar. Revista Cientifica de Educomunicación, 33, 73-81.

García de Torres, E., Rost, A, Edo, C., Said-Hung, E., ArcilaCalderón, C., Sánchez- Badillo, J., Yezers'ka, L., Calderín, M., Rojano, M., Jerónimo, P., Serrano-Tellería, A. y Corredoira, L. (2011). "Uso de Twitter y Facebook por los medios iberoamericanos", El Profesional de la Información, 20 (6), 611-621. Heinonen, A. (1999). Journalism in the age of the net. Tampere: Tampere University Press.

Hermida, A. (2010). "Twittering the news", Journalism Practice, 4 (3), 297-308.

Jenkins, H. (2009). "The revenge of the Origami unicorn: Seven principles of trans- media storytelling", The official web-blog of Henry Jenkins, Disponible en:

http://henryjenkins.org/2009/12/the_revenge_of_the_origa mi_uni.html

Karlsson, M. (2010). "Rituals of transparency: Evaluating online news outlets' uses of transparency rituals in the United States, United Kingdom and Sweden", Journalism Studies, 11 (4), 535545 .

Kovach, B. y Rosenstiel, T. (2007). The elements of journalism: What newspeople should know and the public should expect. New York: Random House.

Lara, T. (2009). "La nueva esfera pública. Los medios de comunicación como redes sociales", Telos. Cuadernos de Comunicación e Innovación, 76, 128-131.

Lasorsa, D. L., Lewis, S. C. y Holton, A. (2012). "Normalizing Twitter: Journalism oractice in an emerging communication space", Journalism Studies, 13 (1), 19-36.

Linnel, G. (2014). "Storytelling in the digital age". En Potts, J. (ed.), The future of writing, 105-114. London: Palgrave Macmillan.

López García, X., Galindo, F. y Villar, M. (1998). "El valor social de la información de proximidad", Revista Latina de Comunicación Social, 7. 
Masip, P., Díaz-Noci, J., Domingo, D., Micó Sanz, J. y Salaverría, R. (2010). "Investigación internacional sobre ciberperiodismo: hipertexto, interactividad, multimedia y convergencia", El Profesional de la Información, 19(6), 568-576.

Messner, M., Linke, M. y Eford, A. (2011). "Shoveling tweets: An analysis of the microblogging engagement of traditional news organizations". Lectura presentada en International Symposium on Online Journalism. Austin (Texas). Disponible en:

https://online.journalism.utexas.edu/2011/papers/Messner20 11.pdf

Messner, M. y Medina-Messner, V. (2013). "Follow me on Wall Street: How busi- ness news media and their journalists engage on Twitter". Lectura presentada en Future of Journalism Conference. Cardiff (UK). Disponible en http://www.marcusmessner.com/wpcontent/uploads/2013/09/FoJC-2013- Messner-+-MedinaMessner-Follow-me-on-Wall-Street.pdf

Mislove, A., Marcon, M., Gummadi, K. P., Druschel, P. y Bhattacharjee, B. (2007). "Measurement and analysis of online social networks". Lectura presentada en Internet Measurement Conference (IMC). San Diego (California).Disponible en: https://mpi-sws.org/ $\sim$ gummadi/papers/imc2007-mislove.pdf

Noguera Vivo, J. M. (2010). "Redes sociales como paradigma periodístico. Medios españoles en Facebook". Revista Latina de Comunicación Social, 65, 176-186.

Orihuela, J. L. (2012). 80 claves sobre el futuro del periodismo. Madrid: Anaya.

Overholser, G. (2009). "What is journalism's place in social media?", Nieman Reports, Disponible en:

http:/ / niemanreports.org/articles/what-is- journalisms-placein-social-media/

Pavlik, J. V. (2001). Journalism and new media. New York: Columbia University Press.

Pedersen, S., Baxter, G., Burnett, S., Goker, A., Corney, D. y Martín, C. (2014). "Backchannel chat: peaks and troughs in a Twitter response to three televised debates during the Scottish Independence Referendum campaign 2014". Disponible en: https://openair.rgu.ac.uk/handle/10059/1086 
Pérez Latre, F. J., Portilla Manjón, I. y Sánchez Blanco, C. (2011). "Social Networks, Media and Audiences a Literature Review", Comunicación y Sociedad, 24 (1), 63-74.

Phillips, A. (2010). "Transparency and the new ethics of journalism", Journalism Practice, 4 (3), 373-382.

Schulte, B. (2010). "The distribution revolution", American Journalism Review., Disponible en: http://www.ajr.org/Article.asp?id=4844.

Scolari, C. A. (2013). Narrativas transmedia. Barcelona: Centro Libros PAPF.

Shoemaker, P. J., Lee, J. H., Han, G. y Cohen, A. (2007). "Proximity and scope as news values". En Devereux, E. (ed.), Media studies: Key issues and debates, 231-248. London: Sage.

Smith, B. (2010). "Socially distributing public relations: Twitter, Haiti, and interactivity in social media". Public Relations Review, 36, 329-335.

Túñez, M. y Guevara, M. (2009). "Framing por proximidad como criterio de noticiabilidad: la curva de las ausencias". Revista Latina de Comunicación Social, 64, 1.030-1.044.

Van der Haak, B., Parks, M. y Castells, M. (2012). "The future of journalism: Networked journalism". International Journal of Communication, 6, 2923-2938.

Walker, W. (2014). "International reactions to the Scottish referendum", International Affairs, 90 (4), 743-759.

Waters, R. D., Tindall, N. T. J. y Morton, T. S. (2010). "Media catching and the Journalist-Public relations practitioner relationship: how social media are changing the practice of media relations". Journal of Public Relations Research, 22 (3), 241 264.

Zhao, S., Grasmuck, S. y Martin, J. (2008). "Identity construction on Facebook: Digital empowerment in anchored relationships", Computers in Human Behavior, 24, 1816-1836.

\section{Otros documentos}

Brooks, L. y Carrell, S. (2014). "Scottish independence: Everything you need to know about the vote", The Guardian, September, 9. Disponible en: 
http://www.theguardian.com/politics/2014/sep/09/-spscottish-independence- everything-you-need-to-know-vote Cassidy, J. (2006). "Me media". The New Yorker, 15, 50-59.

D'Monte, L. (2009). "Swine flu's tweet causes online flutter", Business Standard, April, 29. Disponible en: http:/ /www.businessstandard.com/article/technology/swine- flu-s-tweet-tweetcauses-online-flutter-109042900097_1.html

D'vorkin, L. (2012). "The new language of journalism”. Forbes, 190 (5), 10.

Mangold, W. G. y Faulds, D. J. (2009). "Social media: The new hybrid element of the promotion mix". Business Horizons, 52 (4), $357-$ 365.

Quinlan, M. (2013). "High hopes for an independent Scotland's oil wealth". Petroleum Economist. Disponible en:

http://www.petroleum-economist.com/ articles/politicseconomics/europe-eurasia/2013/high-hopes-for-anindependent-scotlands-oil-wealth

Rachieva-Stover, M. y Burkett, R. (2012). "Using social media to report the news: the good, the bad and the ugly". Lectura presentada en XVIII Newspapers and Community Building Symposium. North Charleston (South California). Disponible en: http://nnaweb.org/pub/doc/stoverburkettpaper.pdf 


\title{
Las televisiones autonómicas en las redes sociales
}

\author{
Julia Fontenla Pedreira \\ Universidade de Vigo
}

\begin{abstract}
PARA CITAR: Fontenla-Pedreira, J. (2019). "Las televisiones autonómicas en las redes sociales”. En Conde-Vázquez, E., Fontenla-Pedreira, J. y RúasAraújo, J. (Eds.), Debates electorales televisados: del antes al después (pp. 233-256). Cuadernos Artesanos de Comunicación, cac154. La Laguna (Tenerife): Latina. DOI: $10.4185 / \operatorname{cac} 154$
\end{abstract}

\section{Resumen}

Las redes sociales han irrumpido en el panorama mediático provocando un cambio en el consumo de contenidos por parte de las audiencias, así como en la generación de opiniones, diálogo e incluso actitudes relacionadas con el ámbito político, especialmente en el público joven.

En esta propuesta se analiza la presencia en las redes sociales, YouTube e Instagram, de los doce canales de televisión autonómica que forman parte de la Federación de Organismos de Radio y Televisión Autonómicos (FORTA): Canal Sur, TV3, TeleMadrid, À punt media, TVG, ETB, TV Canaria, CMM, 7 Región de Murcia, Aragón TV, TPA e IB3 Televisió.

Se realiza un análisis de contenido teniendo en cuenta los siguientes parámetros: suscriptores, vídeos, canales, visualizaciones (en el caso de YouTube); post, seguidores, presencia/ausencia de comentarios en abierto (Instagram). Por otro lado, se estudiará el modo en el que cada una de estos canales retransmitió a través de redes sociales los 
correspondientes debates electorales de los procesos electores autonómicos y municipales de 2015, así como de 2016 (Galicia y País Vasco).

Los resultados establecen una visión general de cómo las televisiones autonómicas emplean estas redes sociales, más visuales, a la hora de generar opinión entre su audiencia. Además, el estudio de las emisiones de los procesos electorales pondrá de manifiesto si las cadenas de servicio público aprovechan los recursos de YouTube e Instagram para suscitar debate o si se mantienen como un canal de comunicación meramente unidireccional.

Palabras claves: debates televisivos, comunicación política, elecciones andaluzas, redes sociales, Instagram, YouTube

\section{Introducción. Redes sociales en el terreno político}

TNTERNET, la Web 2.0 y las redes sociales han provocado una metamorfosis en el consumo de información y han dado paso a la denominada "sociedad red", (Castells, 2009) caracterizada por el consumo de un amplio volumen de información en un mundo hiperconectado. Este auge de flujos informativos, así como de usuarios que crean comunidades y vínculos ha provocado un cambio en todos los sectores. Un cambio que los medios de comunicación han sufrido y que, del mismo modo, se ha trasladado al universo político. Si bien la política se ha valido de los diferentes medios de comunicación para influir sobre la opinión de la ciudadanía, las redes sociales no podían quedar en un segundo plano como herramienta creadora de debate público.

Estamos en un momento en el que los públicos han adquirido la capacidad de estar dentro del proceso comunicativo gracias a la interactividad característica de estas redes sociales, lo que provoca la quiebra del monopolio de poder que poseían medios de comunicación y élites políticas a la hora de construir la realidad social y política (McNair, 2006). 
A esta realidad que ya está más que presente y a la que se han tenido que adaptar políticos y partidos, se enfrentan las televisiones (tanto públicas como privadas), que deberán cambiar su estrategia comunicativa en estas nuevas plataformas generadoras de debate público y político; una adaptación que supone escuchar, responder, y reaccionar ante lo que los usuarios hablan, manteniendo el interés característico del propio medio (Giansante, 2014). Y es que la interactividad de los medios con las diferentes audiencias contribuye a optimizar la difusión y promoción de los contenidos de los soportes tradicionales combinando tradición e innovación (Rodríguez y Sánchez y Toural, 2018).

Teniendo en cuenta los datos del último estudio de Statista (2018) y el Estudio Anual de Redes Sociales (IAB Spain, 2018) relativos a las plataformas actualmente existentes, Facebook, Twitter, YouTube e Instagram son las principales redes sociales (junto a la mensajería privada WhatsApp) que han aumentado su número de usuarios, teniendo como principal atractivo imágenes, vídeos y microblogging a disposición de todos ellos. Estas redes reúnen a una audiencia joven; los usuarios con edades comprendidas entre los 16 y 30 años son quienes las utilizan con más asiduidad, seguidos por un público de entre 31 y 45 años. Entre las preferencias, los jóvenes de entre 16 y 30 años se inclinan por YouTube e Instagram mientras que los adultos de entre 31 y 45 años se decantan por Facebook y YouTube.

Sin tener en cuenta la mensajería privada WhatsApp (empleada prácticamente por la totalidad de la audiencia), Facebook y YouTube ocupan los dos primeros puestos respectivamente en el pódium de usuarios registrados: Facebook se ha convertido en una herramienta clave para motivar al electorado creando relaciones, interactuando con la comunidad y generando sinergias, aunque en el último año ha perdido penetración. Twitter (en el cuarto puesto) ha sido la favorita en lo que se refiere a comunicación y debate político; es la red que mayor interés ha suscitado entre los diferentes actores y que se ha convertido en una herramienta casi obligatoria durante las campañas electorales (López-García, 2016); aunque no significa que sea la red con mayor número de usuarios, sí es una de las que más facilita el 
mantenimiento del bucle dialógico donde todo el mundo (universo Twitter) opina con mayor o menor argumento.

Mientras, la plataforma de vídeo YouTube creada en sus inicios como una red para subir videos caseros, ha sido aprovechada como herramienta de estrategia en campaña electoral con un gran poder viralizador, (Hendricks y Denton, 2010). En el ámbito político, los vídeos de esta temática acumulan miles de visualizaciones siendo los ligados al infoentretenimiento los que despiertan mayor interés entre los usuarios (Berrocal y Campos \& Redondo, 2012).

El caso de Instagram es quizá uno de los menos estudiados a pesar de que ocupa un tercer puesto en usuarios activos (800 millones), siendo la red que más ha aumentado en los últimos años. Datos de IAB Spain o Hootsuit (2018) ponen de manifiesto el crecimiento de Instagram tanto a nivel nacional como internacional respectivamente, algo que debe ser aprovechado como estrategia de comunicación, manteniendo e incluso aumentando el engagement a través de herramientas como el vídeo más allá del post diario, y no menos importante, generando el boca a boca entre los usuarios. Se trata de una red puramente visual y que favorece la movilidad (imágenes que solo se publican a través de teléfono y no pc), cuyos usuarios son fundamentalmente jóvenes (un $90 \%$ menores de 35 años que dejan a un lado Facebook, red social por excelencia).

Los estudios acerca de Instagram en el terreno político son escasos siendo una red empleada mayoritariamente como fórmula de personalización y humanización de candidatos, es decir, un método para ganar popularidad, desmitificar su figura y generar sensación de familiaridad (Quevedo \& Oliva 2017). Consecuencia de ello, se produce un aumento del uso de las imágenes (y también de los vídeos) en la comunicación política, lo que es aprovechado por líderes y partidos (López-Rabadán, López-Meri y Doménech-Fabregat, 2016). Por su parte, Selva-Ruiz y Caro-Castaño (2017) establecen que, en el caso español, prácticamente todas las imágenes que se han compartido en redes sociales relativas a partidos y candidatos están directamente relacionadas con su ejercicio profesional y son pocas aquellas que intentan humanizar al político mostrando contenidos de su vida 
personal., siguiendo una estrategia tradicional propia de la mediatización política (Mazzoleni y Schulz, 1999).

Es esta una de las redes que ocupa mayor interés en la actualidad y que no debe pasar desapercibida entre las televisiones públicas y privadas precisamente por la atención que atrae entre usuarios jóvenes, y por el crecimiento que ha sufrido respecto a las demás (un 35\% en el último año, frente al 12\% de Twitter, y una caída del 4\% de Facebook) (Statista, 2018).

\subsection{Debates, redes sociales y televisión pública en Europa}

Los debates electorales entre candidatos a la presidencia del Gobierno son un producto televisivo arraigado a la sociedad española actual, un debate que ha tenido que evolucionar desde la antigua confrontación bipartidista hasta nuevos formatos que enganchen a públicos jóvenes e incorporando otras fuerzas representativas. Las redes sociales han impulsado esta transformación de los formatos de debate, otorgando a los usuarios la capacidad de difundir sus opiniones y comentar en tiempo real el debate, generando a su vez otro debate paralelo sobre lo acontecido en el debate televisado, viralizando o ignorando ideas, o incluso agregando una nota de humor a los contenidos tratados. Además, estas plataformas funcionan como medios que pueden predecir significativamente la participación política, y pueden mostrar el nivel de compromiso e incluso de participación en la conversación política (Vaccari, Chadwick y O’Loughlin, 2015).

En los medios sociales, y durante los debates televisados, los partidos manifiestan un claro propósito de dar mayor visibilidad a sus mensajes, más que de generar un auténtico debate político digital (LozanoAguiar, García-Orosa, 2017). De hecho, tal y como señalan, entre otros, Dader y Campos (2017), los partidos políticos suelen hacer uso, durante las campañas electorales, de voluntarios para difundir información en las redes sociales. No se trata de generar debate con los ciudadanos, sino de dar una imagen de "popularización" de los contenidos y mensajes partidistas. Esta estrategia es igualmente útil para generar un determinado "encuadre" (framing) en tiempo real o de 
forma anticipada sobre grandes eventos como los debates (Kreiss, 2014).

En la actualidad, las televisiones no cuentan con una regulación del tratamiento y la cobertura de los debates electorales a través de las redes sociales, ni en lo que atañe a la participación de los candidatos a través de ellas (Rúas, Holgado y Amil, 2018). Un componente que debería de tenerse en cuenta en el panorama actual y que así lo han hecho organismos reguladores de radiodifusión, como la Broadcasting Authority de Irlanda (BAI) que señalan que es indispensable aplicar en sus canales dependientes, medidas que garanticen que sus referencias en las redes sociales sean precisas, justas, objetivas e imparciales. En este sentido, Rúas, Holgado y Amil mencionan que esos principios de fomento del debate, pluralismo y participación ya han sido tenidos en cuenta y están presentes en la Ley de la Radio y la Televisión de Titularidad Estatal de 2006, y que han de mantenerse y evolucionar adaptándose a las nuevas demandas y necesidades sociales. Así se recoge en el informe "Un nuevo modelo para un tiempo nuevo" (Bustamante, 2015), donde se destaca la necesidad de ajustar el servicio público de televisión a la nueva era digital, pues dispone de herramientas para satisfacer los requerimientos ciudadanos en los medios sociales y, por tanto, "tiene la responsabilidad de promover la producción cultural y de conocimiento por toda la sociedad”, además de funcionar como arma contra la extinción de la tv pública o de su pérdida de influencia social.

Esta evolución modificaría el consumo lineal propio de la programación tradicional, y daría paso a la denominada televisión social e interactiva donde los ciudadanos participan activamente compartiendo contenidos, respondiendo a sus demandas y reclamaciones como derecho y que se contrapone con el modelo de comunicación que considera las audiencias como mercancía (Esteinou, 2017). Algunos de los análisis realizados sobre la influencia de las segundas pantallas en la mejora de la calidad del debate político, muestran que las redes sociales se utilizan para dotar de una mayor difusión a los planteamientos propios de las cadenas de televisión (sobre todo a través de sus hashtags) y que una mayor actividad en las redes no está directamente relacionada con la calidad de la 
conversación ni contribuye al intercambio de ideas u opiniones (CalvoRubio, 2018), fomentando un debate realmente provechoso. Y aunque los partidos han incrementado en los últimos años su estrategia en redes sociales como Twitter (observándose un crecimiento importante de la audiencia social frente a la audiencia tradicional en los debates electorales televisados correspondientes a las elecciones generales de 2015 y 2016), lo cierto es que las formaciones políticas siguen centrándose en replicar únicamente sus mensajes institucionales y la audiencia social no encuentra aún una integración real (Rodríguez y Saavedra, 2017) en las estrategias de los medios de comunicación y actores políticos.

En este contexto, es importante tener en cuenta la naturaleza del medio en el que se organiza el debate electoral. Las televisiones públicas, dentro del cumplimiento de sus funciones como servicio público sin fines de lucro, deben responder al valor público y social de los debates electorales. Por eso es necesario medir el impacto que generan a través de sus redes sociales $\mathrm{y}$, además, tener en cuenta el valor de la conversación e interactividad que logran a través de sus cuentas y perfiles. En este sentido, el debate público a través de las redes sociales no solo es un indicio del interés de los ciudadanos por la política o de la coincidencia entre la agenda política y social, sino una obligación para las instituciones públicas. Ambas circunstancias (el valor académico y público) respaldan el interés de la relación entre redes sociales digitales y debates públicos televisados.

Hoy prácticamente todas las televisiones públicas europeas tienen perfil en las redes sociales más multitudinarias, aunque las utilizan con diferentes fines, en la mayoría de los casos para promocionar programas de televisión y conseguir interactividad con sus audiencias más que para promover el debate político. Por normal general, las televisiones crean un producto propio para los programas más exitosos (generalmente Facebook, Twitter., Instagram), y las que poseen mayor envergadura, aumentan su flujo comunicativo a través de un canal propio en YouTube o a través de redes que les permitan introducir contenidos interactivos. En el caso de los debates electorales, las televisiones públicas hacen uso de estas redes también como forma de 
autopromoción del mismo debate, o creando hashtags que muevan a los usuarios entre red y red.

A pesar del aumento y variedad de redes sociales, las televisiones públicas europeas continúan utilizando como plataformas principales Facebook y Twitter, cuyos perfiles obtienen más popularidad y a través de la que articulan su estrategia de comunicación. Destaca entre lo más seguido los perfiles de YouTube de países como Reino Unido, Polonia, Irlanda e Italia (FORTA, 2016); una plataforma en la que las corporaciones públicas vuelcan su contenido audiovisual para luego hacer circular ese contenido por el resto de perfiles sociales a través del enlace (despunta el uso de esta plataforma por la BBC, con más de tres millones de followers convirtiéndose en el canal con mayor visibilidad de todas las televisiones públicas europeas). En España, las diferencias en el uso de las redes sociales a nivel autonómico no son muy notables entre unas y otras corporaciones públicas, siendo la televisión autonómica de Cataluña y el Ente Público de Radio Televisión de Madrid, los grupos con más perfiles y los más activos en las redes sociales. Este empleo desigual de las diferentes redes sociales repercute en la cobertura de los debates electorales, sin que se exploten al máximo todas sus potencialidades. Las televisiones públicas deben sondear en qué red social les conviene estar presente para aprovechar las posibilidades que estas ofrecen, y no solo mostrarse como escaparate de lo que ha sido el debate, sino incentivando a los usuarios a permanecer en ellas participando y consiguiendo feedback.

\section{Metodología}

En este estudio se realiza un análisis de contenido cuantitativocualitativo de las redes sociales Instagram y YouTube (por su carácter predominante audiovisual) de los doce canales de televisión autonómicos que forman parte de la Federación de Organismos de Radio y Televisión Autonómicos (FORTA) --Canal Sur, TV3, TeleMadrid, À punt media, TVG, ETB, TV Canaria, CMM, 7 Tv Región de Murcia, Aragón TV, TP A, IB3 Televisió-- con el fin de establecer si los contenidos políticos son una prioridad en ambas plataformas. Todos los datos recogidos corresponden a la cuantificación realizada hasta finales de enero de 2019. 
Se parte de la hipótesis de que los canales de servicio público sí emplean ambas redes como segundas pantallas para distribuir contenidos, pero no como medio de debate político. A partir de esta premisa y teniendo en cuenta las particularidades de cada una de las dos, se utilizarán los siguientes parámetros: suscriptores, vídeos, canales, visualizaciones (en el caso de YouTube); número de post, número de seguidores, presencia/ausencia de comentarios en abierto, canal IGTV (Instagram).

Por otro lado, se realiza un seguimiento de las publicaciones en ambas plataformas relativas a los correspondientes debates electorales de los procesos electores autonómicos y municipales de 2015 y de 2016 (Galicia y País Vasco), así como de las últimas elecciones andaluzas de 2018 y un análisis de contenido correspondiente a los post de dichas publicaciones.

Tabla 1. Cuentas oficiales objeto de estudio

\begin{tabular}{|l|l|l|}
\hline Canal FORTA & Cuenta Oficial Instagram & Canal Oficial YouTube \\
\hline Canal Sur & @canalsurradiotv & /canalsur \\
\hline A Punt Media & @apunt_media & /ápuntmedia \\
\hline TV Canaria & @trtvces & /TelevisionCanaria \\
\hline Aragón Tv & $@$ aragontv & /aragóntv \\
\hline TV3 & @tv3cat & /tv3 \\
\hline TVG & $@$ tvgalicia & /TelevisióndeGalicia \\
\hline CMM & @cmm_es & /CMMCastilla-LaManchaMedia \\
\hline IB3 & $@$ ib3 & /ib3televisió \\
\hline TeleMadrid & @telemadrid & /telemadrid \\
\hline EITB & $@$ eitb & /EiTB \\
\hline RTPA & @rtpa_oficial & *no tiene canal \\
\hline
\end{tabular}

Fuente: Elaboración propia

\section{Resultados}

Tras un seguimiento exhaustivo de la actividad de los canales de la FORTA en redes sociales se observa que, como en el resto de televisiones públicas europeas, todas presentan perfiles en Facebook y Twitter con publicaciones regulares en sus perfiles con contenidos que 
tocan temáticas diversas (entretenimiento, política, internacional, sucesos, deporte, etc.), pero en el caso de YouTube e Instagram, objeto de este estudio, su uso no responde a una estrategia de comunicación establecida.

En la red social YouTube, las cadenas de televisión de la FORTA presentan escasa atención. Todas poseen canal oficial excepto la asturiana TPA, pero con un uso es muy desigual:

-Todas excepto tres (7 Tv Región de Murcia, À punt Media -las más recientes- y la inexistente en YouTube TP $A$ ), nacen en los primeros años de inicio de YouTube (2006-2007) y remiten a canales de la propia cadena.

-Tan sólo cuatro (Canal Sur TeleMadrid, EITB y Tv3) agregan contenido diariamente; las mismas que se sitúan en cabeza en cuanto a número de visualizaciones y suscriptores.

Tabla 2. Seguimiento YouTube

\begin{tabular}{|l|l|l|l|}
\hline Canal FORTA & $\begin{array}{l}\mathbf{N}^{\mathbf{o}} \\
\text { suscriptores }\end{array}$ & Vídeos & $\begin{array}{l}\mathbf{N}^{\mathbf{o}} \\
\text { visualizaciones }\end{array}$ \\
\hline Canal SUR & 539.635 & 22.863 & 384.303 .431 \\
\hline TeleMadrid & 395.408 & 8.709 & 286.850 .100 \\
\hline EITB & 326.120 & 41.138 & 304.458 .566 \\
\hline TV3 & 248.758 & 28.965 & 252.706 .969 \\
\hline CMM & 121.673 & 39.270 & 114.061 .996 \\
\hline IB3 & 61.295 & 34.520 & 49.917 .772 \\
\hline También canal de IB3Noticies & 2.828 & 35.226 & 4.747 .157 \\
\hline TVCanaria & 47.769 & 6.872 & 22.735 .491 .609 \\
\hline $\begin{array}{l}\text { También Canal de Informativos } \\
\text { TVC }\end{array}$ & 9.410 & 19.835 & 4.923 .470 \\
\hline TVG & 25.606 & 3.177 & 20.137 .848 \\
\hline ARAGÓN TV & 17.619 & 3.175 & 7.818 .994 \\
\hline 7 TV Región de Murcia & 12.711 & 1.445 & 5.394 .512 \\
\hline À Punt Media & 851 & 15 & 296.910 \\
\hline RTPA & No tiene canal** & & \\
\hline & & & \\
\hline
\end{tabular}

Fuente: Elaboración propia

En cuanto a contenidos de índole política (excepto las ya mencionadas que mantienen este canal en segundo plano) incorporan vídeos de emisiones relacionadas respondiendo a criterios de búsqueda por 
palabras clave (elecciones, debate político, campaña electoral, análisis político, etc.). Aunque los canales autonómicos trasladan de forma aplastante a esta plataforma contenidos informativos $y$ predominantemente de entretenimiento (siendo la televisión pública andaluza, Canal SUR, la más popular), todas incorporan contenido relativo a programación especial elecciones.

Tabla 3. Contenidos debate Youtube

\begin{tabular}{|c|c|c|}
\hline Canal FORTA & $\begin{array}{l}\text { Contenido } \\
\text { Keywords }\end{array}$ & Debate elecciones autonómicas \\
\hline Canal Sur & Sí & $\begin{array}{l}\text { Debate 2D } 2018 \text { (19 de noviembre } 2018) \text { - } \\
\text { 5.428 visualizaciones; } 60 \text { reacciones ( } 51 \\
\text { likes/9dislike); } 49 \text { comentarios. Debate } 2015\end{array}$ \\
\hline TeleMadrid & Sí & $\begin{array}{l}\text { Debate Comunidad de Madrid } 2015 \text { (12 } \\
\text { de mayo 2015)- } 10.183 \text { visualizaciones; } 36 \\
\text { reacciones ( } 36 \text { likes/4dislikes); } 28 \\
\text { comentarios }\end{array}$ \\
\hline EITB & Sí & $\begin{array}{l}\text { Debate elecciones 25S } 2016 \text { (16 de } \\
\text { septiembre } 2016)-1.574 \text { visualizaciones; } 12 \\
\text { reacciones (10 likes/ } 2 \text { dislike); } 1 \text { comentario }\end{array}$ \\
\hline TV3 & Sí & $\begin{array}{l}\text { Debate Electoral Parlament 21D (19 de } \\
\text { diciembre } 2017)-17.575 \text { visualizaciones; } 213 \\
\text { reacciones (191 likes/22dislikes); } 176 \\
\text { comentarios }\end{array}$ \\
\hline CMM & Sí & No \\
\hline IB3 & Sí & No \\
\hline $\begin{array}{l}\text { También canal } \\
\text { de IB3Noticies }\end{array}$ & Sí & No \\
\hline TVCanaria & Sí & \\
\hline $\begin{array}{l}\text { También Canal } \\
\text { de Informativos } \\
\text { TVC }\end{array}$ & Sí & $\begin{array}{l}\text { Debates elecciones 2015: } 791 \\
\text { visualizaciones; } 8 \text { likes, } 0 \text { comentarios }\end{array}$ \\
\hline TVG & Sí & $\mathrm{No}$ \\
\hline ARAGÓN TV & Sí & No \\
\hline $\begin{array}{l}7 \text { TV Región de } \\
\text { Murcia }\end{array}$ & No & No \\
\hline À Punt Media & No & $\mathrm{No}$ \\
\hline RTPA & $\begin{array}{l}\text { No tiene } \\
\text { canal*** }\end{array}$ & \\
\hline
\end{tabular}

Fuente: Elaboración propia 
Tabla 4. Comentarios debate

\begin{tabular}{|l|l|}
\hline Canal FORTA & Comentarios destacados durante el debate \\
\hline Canal Sur & "Votad al Pacma, que es el único que no roba y mira por los \\
animales y el bienestar de las personas". \\
"Por lo tanto votemos a VOX para gobernar este país \\
aventajamos todos seguro etc etc" \\
"Ni uno de los cuatro ha contestado como van a bajar el \\
paro. Me habría gustado ver a VOX a ver que hubiese \\
propuesto" \\
"VOXESESESESESdefender Andalucía y España en las urnas, \\
basta de corrupción y basta de inmigración!!!!"
\end{tabular}

Fuente: Elaboración propia 
En lo referido a los últimos y respectivos debates electorales autonómicos andaluces de 2018, solamente cinco se hacen eco y así se refleja en sus canales: Canal Sur, TeleMadrid, EITB, TV3 y TVCanaria (canal de Informativos); todos permiten comentarios en abierto pero tan sólo los debates de EITB y Canal Sur despiertan mayor reacción de la audiencia y diálogo entre los seguidores, con comentarios predominantemente críticos o en desacuerdo, mientras que para los debates de los procesos electores autonómicos y municipales de 2015 en Galicia y de 2016 País Vasco, no han sido recogidos por los propios perfiles oficiales del canal, sino que han sido subidos por perfiles privados.

A la hora de abordar los datos extraídos de Instagram, hay que tener en cuenta la relativa "juventud" de la red (2010). Los resultados son los siguientes:

Tabla 5. Seguimiento Instagram

\begin{tabular}{|l|l|l|l|}
\hline Canal FORTA & Followers & $\begin{array}{l}\mathbf{N}^{\mathbf{o}} \\
\text { Post }^{-}\end{array}$ & Seguidos \\
\hline TV3 & $118 \mathrm{k}$ & 666 & 66 \\
\hline Á Punt Media & $32,2 \mathrm{~K}$ & 543 & 59 \\
\hline TVG & $24.9 \mathrm{~K}$ & 970 & 251 \\
\hline TeleMadrid & $16,7 \mathrm{~K}$ & 826 & 44 \\
\hline $\begin{array}{l}\text { También perfil de Informativos TeleMadrid } \\
\text { (/ informativos telemadrid) }\end{array}$ & 1.377 & 294 & 460 \\
\hline ARAGÓN TV & $16,6 \mathrm{~K}$ & 809 & 161 \\
\hline CanalSur & $12,6 \mathrm{~K}$ & 879 & 162 \\
\hline CMM & 8.304 & 634 & 342 \\
\hline IB3 & 6.885 & 541 & 373 \\
\hline EITB & 6.534 & 653 & 17 \\
\hline 7 TV Región Murcia & 1.992 & 33 & 79 \\
\hline RTPA & 1.559 & 339 & 1099 \\
\hline TVCanaria & 1.055 & 0 & 0 \\
\hline & & & \\
\hline
\end{tabular}

Fuente: Elaboración propia

Todos los canales de televisión pública autonómica poseen cuenta oficial en esta red, pero su uso también es muy desigual al igual que en YouTube. En lo referido a seguidores encabezan la lista la autonómica catalana TV3, À Punt Media (Valencia), y TVG, y en la cola TVCanaria, 
TP A y 7 Tv Región de Murcia. La autonómica gallega (TVG) encabeza el número de publicaciones, seguida de TeleMadrid junto a su perfil asociado de Informativos; y Canal Sur. En el lado contrario se sitúan la TV Canaria, que carece de publicaciones; y 7 Tv Región de Murcia, con un total de 33 post). Los resultados son los siguientes:

Tabla 6. Contenidos Instagram

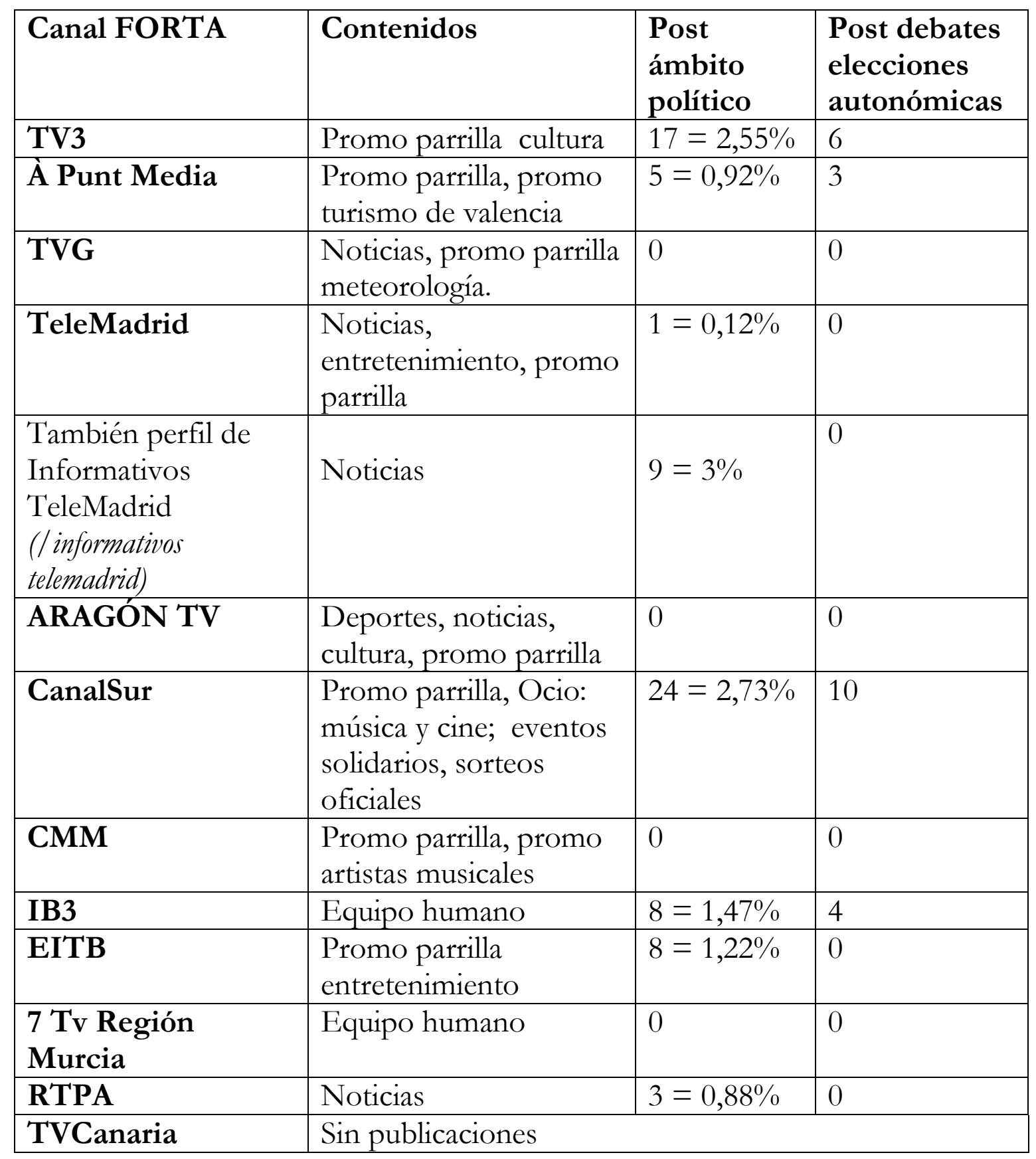

Fuente: Elaboración propia 
En cuanto a los post con contenido político es prácticamente mínimo suponiendo entre un uno y un tres por ciento del total de post, por lo que no extraña que el contenido referido a debates electorales sea prácticamente inexistente; y en aquellos posts que, si se introduce, se limita a una imagen de los representantes políticos antes o después del debate; de la preparación del equipo y de los sets antes del debate, y como contenido promocional de las cadenas. El $70 \%$ de las publicaciones corresponden a post que promocionan la parrilla televisiva y noticias informativas.

Tabla 7. Instagram IGTV

\begin{tabular}{|l|l|l|}
\hline Canal FORTA & Fecha primer post & Igtv \\
\hline TV3 & 22 de abril de 2015 & No \\
\hline Á Punt Media & $\begin{array}{l}\text { 11 de diciembre de 2017 (no } \\
\text { existía cuenta en etapa } \\
\text { electoral) }\end{array}$ & No \\
\hline TVG & 18 de marzo de 2014 & No \\
\hline TeleMadrid & 12 de abril de 2012 & 4 \\
\hline $\begin{array}{l}\text { También perfil de Informativos } \\
\text { TeleMadrid (/ informativos telemadrid) }\end{array}$ & 24 de agosto de 2016 & No \\
\hline ARAGÓN TV & $\begin{array}{l}\text { 22 de octubre de 2014 (no } \\
\text { hacen mención a redes) }\end{array}$ & 2 \\
\hline CanalSur & 5 de enero de 2015 & 22 \\
\hline CMM & 8 de julio de 2016 & No \\
\hline IB3 & 14 de febrero de 2014 & No \\
\hline EITB & 12 de julio de 2017 & No \\
\hline 7 TV Región Murcia & 10 de noviembre de 2015 & No \\
\hline RTPA & 2 de abril de 2017 & No \\
\hline TVCanaria & Sin publicaciones & \\
\hline
\end{tabular}

Fuente: Elaboración propia

Ninguno aprovecha el canal Instagram Tv (IGTV) que permite subir vídeos de hasta una hora de duración con un peso máximo de 5,4Gb), adaptados a móvil (formato vertical) competencia de YouTube en estos dispositivos. 
Tabla 8. Post Instagram contenido político

\begin{tabular}{|c|c|}
\hline Canal F0RTA & Post contenido político \\
\hline \multirow[t]{6}{*}{ À Punt Media } & $\begin{array}{l}\text { En Stories destacadas: (sobre el Debate de Política General de la Comunidad Valenciana) Debat de } \\
\text { políitica General \#DebatCVÀPunt } 79 \text { /80 stories de hace } 11 \text { semanas }\end{array}$ \\
\hline & $\begin{array}{l}28 \text { de septiembre de 2016- "Màsters, titols, plagis... què passa a la universitat? És una institució sota } \\
\text { sospitta? Quin és el paper del Pla Bolonya? Posem la universitat a examen aquest divendres en 'La } \\
\text { qüestió'. \#LQMàsterFrau @llapaunt" }\end{array}$ \\
\hline & $\begin{array}{l}11 \text { de septiembre de 2018- "Segueix en directe el \#DebatCV en la televisióo, ràdio, web, xarxes i també } \\
\text { mitjiançant els stories d'I'nstagram. \#DebatCVÀPunt in @apunt_media" }\end{array}$ \\
\hline & $\begin{array}{l}11 \text { de septiembre de 2018-" VÍDEO | \#DebatCVÀPunt Com serà l'últim debat de política general de } \\
\text { la legislatura? Enguany el debat comença mitja hora abans i les propostes de resolució es limiten a } 12 . \\
\text { \#DebatCV" }\end{array}$ \\
\hline & $\begin{array}{l}4 \text { de julio de 2018- "Continuem amb la programació especial pel tercer aniversari del govern de } \\
\text { Botànic. Aquesta nit, a les 21:00 h, entrevistem el president de la @generalitatvalenciana, } \\
\text { @aximopuigferrer. \#3anysBotànic" }\end{array}$ \\
\hline & $\begin{array}{l}3 \text { de julio de 2018- "Tres anys després de la presa de possessió de Ximo Puig com a president de la } \\
\text { Generalitat, analitzem la gestió del govern nascut de l'acord del Botànic. } \square \text { Aquesta nit, a les 21:30 h, } \\
\text { citem, als estudis d'A Punt Mèdia, els síndics Isabel Bonig, del PP; Manolo Mata, del PSPV-PSOE; Fran } \\
\text { Ferri, de Compromís; Antonio Estañ, de Podem i Mari Carmen Sanchez, de Ciutadans. }\end{array}$ \\
\hline TV CANARIA & 0 \\
\hline ARAGÓN TV & 0 \\
\hline TVG & 0 \\
\hline 7 Tv Región Murcia & 0 \\
\hline CMM & 0 \\
\hline
\end{tabular}




\begin{tabular}{|c|c|}
\hline$\frac{\text { TeleMadrid }}{\text { También Perfil informativos TeleMadrid }}$ & \multirow{3}{*}{$\begin{array}{l}3 \text { de mayo de 2017- "Entrevista a Cristina Cifuentes" } \\
21 \text { de noviembre de 2018- "VíDEO: Hoy a las 21:15 @ jgm78 entrevista a Manuela Carmela en } \\
\text { Telemadrid \#CarmenaTelemadrid" (Vídeo presentador promo) }\end{array}$} \\
\hline \multirow[t]{11}{*}{ También Perfil informativos TeleMadrid } & \\
\hline & \\
\hline & $\begin{array}{l}12 \text { de noviembre de 2018- "Vídeo: Esta noche entrevista a @ignacioaguado a las } 21.15 \text { @cs Madrid" } \\
\text { (Vídeo promocional) }\end{array}$ \\
\hline & \multirow{2}{*}{$\begin{array}{l}27 \text { de septiembre de } 2018 \text { - "VÍDEO Duque da explicaciones \#news \#noticia \#telemadrid" } \\
12 \text { de septiembre de } 2018 \text { - "El caso de los máster en el ·Tn2 con @igm78 @_rocio_delgado_\#news } \\
\text { \#noticias" }\end{array}$} \\
\hline & \\
\hline & \multirow{2}{*}{$\begin{array}{l}8 \text { de septiembre de 2018- "VÍDEO:Este lunes en directo entrevista a \#ANGELGARRIDO } \\
\text { @angelnostromo a las 21:15h" (Vídeo promocional) }\end{array}$} \\
\hline & \\
\hline & $\begin{array}{l}29 \text { de agosto de 2018- "Manifestaciones de la ultraderecha en Alemania \#tv \#programa@telemadrid } \\
\text { @ jgm78" (Vídeo noticia) }\end{array}$ \\
\hline & $\begin{array}{l}7 \text { de julio de 2018- "Tabarnia y la república catalana ya tienen su DNI propio. \#TN2 @informativo } \\
\text { con@jgm78" }\end{array}$ \\
\hline & 8 de junio de 2018- "VÍDEO@astro_duque fichaje de Sánchez. \#noticias@ @telemadrid" \\
\hline & 14 de enero de 2017- "VÍDEO: Las fotos más compartidas de Barack Obama en redes sociales" \\
\hline \multirow[b]{8}{*}{ EITB (/eitb) } & $\begin{array}{l}2 \text { de noviembre: "VÍDEO: Esta noche, en \#ETB2, a las 22:30h, \#360tudecides. Con \#Vox a debate } \\
\text { \#actualidad \#altasu" (vídeopromocional) }\end{array}$ \\
\hline & \multirow{2}{*}{$\begin{array}{l}8 \text { de junio de 2018: "El nuevo gobierno de Pedro Sánchez a debate, esta noche, en \#360tudecides. } \\
\text { Síguelo, a las 22:15 horas, en \#ETB2 y \# eitibeus". } \\
\text { 6 de junio de 2018: "VÍDEO Euskal Telebista EMITIRÁ, ESTA NOCHE, UN PROGRAMA } \\
\text { ESPECIAL SOBRE EL NUEVO GOBIERNO DE Pedro Sánchez. A las 22:15 horas en \#ETB2 y } \\
\text { @eitbeus" (Vídeo promocional) }\end{array}$} \\
\hline & \\
\hline & $\begin{array}{l}\text { 1 de junio de 2018: "La moción de censura y sus consecuencias, a las 22,30 horas, en \#360tudecides en } \\
\text { \#ETB2 y \#eitbeus." }\end{array}$ \\
\hline & $\begin{array}{l}24 \text { de abril de 2018: "VÍDEO: Pentsiodunen erreaalitatea aztergai, gaur gauean, \#urhanditan saioan. } \\
\text { \#GertatzenAriDa" (VÍDEO NOTICIA) }\end{array}$ \\
\hline & $\begin{array}{l}18 \text { de abril de 2018: "EiTBk jakin ahai izan duenez, ETAk desegitea iragarriko du maiatzeko lehen } \\
\text { asteburuan. \#eta \#eitb \#etb }\end{array}$ \\
\hline & $\begin{array}{l}23 \text { de febrero de 2018: "ETB2 estrena esta noche `360. Tú decides", programa presentado por } \\
\text { Arantza Ruíz y Eider Hurtado que ofrecerá un nuevo giro de la actualidad política y social. A las } 22.30 \\
\text { en ETB2 y eitb.eus. \#etb \#eitb \#360tudecides }\end{array}$ \\
\hline & $\begin{array}{l}25 \text { de octubre de 2017: "Esta noche no te pierdas el documental "Patria (s). Catalunya manual de } \\
\text { instrucciones" presentado por el actor de "Polonia" Queco Novell \#patrias \#etb2". (VÍDEO PROMO } \\
\text { HUMOR) }\end{array}$ \\
\hline \multirow[b]{3}{*}{ RTPA } & 28 de septiembre de 2017: "Qué opina Asturias del proceso soberanista catalán? (Imagen encuesta) \\
\hline & $\begin{array}{l}25 \text { de septiembre: "VIDEO: Rafael Arenas, astur catalán, catedrático de Derecho Internacional Privado } \\
\text { en la UAB. "El resto de España va a despertar a partir del día } 2 \text { y se dará cuenta de la gravedad de lo } \\
\text { que está pasando aquí". La entrevista completa el sábado en Asturias Semana". }\end{array}$ \\
\hline & 12 de mayo de 2017: "Debate de candidatos a las primarias del PSOE" (Foto Promo) \\
\hline & \multirow{2}{*}{$\begin{array}{l}10 \text { de abril de 2018: "Avui hem traslladat l'espai \#AIDiaIB3 fins a Brussel.les per fer un programa } \\
\text { especial des del Parlament Europeu \#IB3 \#IB3Ràdio \#actualitat \#informació" (Foto plató) } \\
28 \text { de abril de 2017:" Avui l'equip del programa \#AlDiaIB3 en directe des del Parlament Europeu } \\
\text { \#JoSomIB3 \#IB3Ràdio \#ServeiPúblic \#balears \#ràdio \#informació (Foto plató) }\end{array}$} \\
\hline & \\
\hline & $\begin{array}{l}6 \text { de marzo de 2016:" Segona part del programa @duesvoltes \#EspecialInvestidura amb l'opinió dels } \\
\text { senadors per les illes \#FrancescAntich i @JoseRamonBauza i periodistes experts en política a Balears. } \\
\text { \#ib3tv (FOTO plato candidatos en tribuna) }\end{array}$ \\
\hline & $\begin{array}{l}6 \text { de marzo de 2016: "I ara què? Hem reunit a representants dels partits polítics a Balears per tractar } \\
\text { l'actual situació política estatal. \#EspecialInvestidura \#DuesVoltes \#ib3tv" (Foto plató candidatos } \\
\text { posando) }\end{array}$ \\
\hline & $\begin{array}{l}16 \text { de diciembre de 2015: "Avui darrer a } 6 \text { amb motiu de les \#Eleccions2015 a les 21,30h. Ja tenim el } \\
\text { nostre plató preparat! \#DebatIB3 \#IB3 \#IB3televisió \#IB3ràdio \#debat \#política \#20D \#IllesBalears } \\
\text { \#instagramers" (Foto plató) }\end{array}$ \\
\hline & $\begin{array}{l}9 \text { de diciembre de 2015: "Podeu seguir en directe el primer del debats electorals a \#IB3. Part dels } \\
\text { professionals que estan fent possible aquesta retransmissió. \#DebatIB3 \#Eleccions2015 \#IB3TV } \\
\text { \#IB3ràdio \#pick \#pickoftheday \#instagramers \#photo \#photooftheday" (foto Back) }\end{array}$ \\
\hline & \multirow{2}{*}{$\begin{array}{l}19 \text { de junio de 2014: "Avui és un dia especial i amb molta feina als mitjans de comunicació! A IB3 ja } \\
\text { estam en directe per oferir el programa especial de proclamació del nou rei Felipe VI \#Moment IB3" } \\
19 \text { de mayo de 2014: "Ja tenim a plató als cinc candidats que protagonizen avui vespre el debat amb } \\
\text { motiu de les \#EleccionsEuropees del proper 25M. Joan Frontera serà el moderador d'aquest debat. } \\
\text { També està present el director general de l'Ens Públic de Radiotelevisió de les Illes Balears, José } \\
\text { Manuel Ruiz. (23.25h) }\end{array}$} \\
\hline IB3 & \\
\hline
\end{tabular}




\begin{tabular}{|c|c|}
\hline & $\begin{array}{l}12 \text { de abril de 2018: "@faqstv3 ha anat al \#PaísBasc per parlar del cas d'\#Altsasu, els CDRs, el } 155 \text { i } \\
\text { la investidura. @laurarosel entrevista Joseba Egibar, portaveu del PNB al Parlament basc. Ho veurem } \\
\text { dissabte, a \#FAQSTV3." }\end{array}$ \\
\hline & $\begin{array}{l}21 \text { de diciembre: "Ultims retocs per a 1’E17: Especial eleccions". A les 19:00 arrenca amb Toni } \\
\text { Cruanyes, Lídia Heredia, Carles Prats i Raquel Sans. Pere Bosch será l'encarregat de seguir les xarxes } \\
\text { sociais durant la nit electoral \#21DTV321d" (ds imágenes del back) }\end{array}$ \\
\hline & $\begin{array}{l}19 \text { de diciembre de 2017: "Els candidats abans déntrar al plató del \#DebatTV3 del \#21D (seri de } 7 \\
\text { imágenes con los candidatos en actitud de distención o preparándose) }\end{array}$ \\
\hline & $\begin{array}{l}18 \text { de diciembre de 2017: "Tot a punt per a lúltim gran debat del 21D amb set dels candidats dúnes } \\
\text { eleccions extraordinàries \#DebatTV3" }\end{array}$ \\
\hline & $\begin{array}{l}22 \text { de enero de 2017: "Jo pregunto", els ciutadans pregunten al president de la Generalitat, Carles } \\
\text { Puigdemont" (Plató de TV) }\end{array}$ \\
\hline & $\begin{array}{l}22 \text { de enero de 2017: "El Teatre Conservatori de Manresa convertir per un día en plató. Tot a punt pel } \\
\text { \#jopreguntotv3" (Plató de TV) }\end{array}$ \\
\hline & $\begin{array}{l}20 \text { de enero de 2017: "Hem passat el matí al Teatre Conservatori de Manresa (Bages), ultimant els } \\
\text { preparatius perquè diumenge els ciutadans preguntin al president Carles Puigdemont sobres els temes } \\
\text { que mes els preocupen "Jo pregunto", diumenge, a les } 21.25 \text { \#entrevistaalpresident \#endirecte } \\
\text { \#Manresa \#Generalitat" (Plató de TV) }\end{array}$ \\
\hline & $\begin{array}{l}22 \text { de septiembre de 2016: "EL president @ carlespuigdemont amb @andreubuenafuente gravant una } \\
\text { entrevista "Fora de serie" \#BNFPuigdemontTV3" }\end{array}$ \\
\hline & \begin{tabular}{|l}
22 de septiembre de 2016: "@MarquesAgnes i @Toni_Cruanyes preparant l'especial d'eleccions \\
basques i galleges. Diumenge el fons verd será un mar de dades \#25STV3" (Foto presentadores)
\end{tabular} \\
\hline & $\begin{array}{l}21 \text { de mayo de 2015: "L'altra cara de la foto de familia dels candidats a lálcaldia de Barcelona abans de } \\
\text { comencar el @ DebatBCN al ".Cat"". (Foto de candidatos de espaldas y de frente los medios) }\end{array}$ \\
\hline & $\begin{array}{l}20 \text { de mayo de 2015: "El plató de ".CAT" es prepara per acollir els debats municiplas que s'emetran } \\
\text { demà a la nit. Ariadna Oltra presentará el debat amb els candidats de Barcelona. (Foto plató) }\end{array}$ \\
\hline & $\begin{array}{l}12 \text { de mayo de 2015: "La campanya electoral és una cursa contrarrellotge i desprès del debat } \\
\text { \#MunicipalsBCN, els candidats tenen altres cites" }\end{array}$ \\
\hline & $\begin{array}{l}\text { 12 de mayo de 2015: "Al final del debat \#MunicipalsBCN els candidats comenten la jugada amb els } \\
\text { seus assesors" (Foto Alfred Bosch) }\end{array}$ \\
\hline & $\begin{array}{l}12 \text { de mayo de 2015: "Al final del debat \#MunicipalsBCN els candidats comenten la jugada amb els } \\
\text { seus assesors" (Foto Candidata }\end{array}$ \\
\hline & $\begin{array}{l}12 \text { de mayo de 2015: "Al final del debat \#MunicipalsBCN " (Foto Alfred Bosch, Xavier Trias, Jaume } \\
\text { Collboni en ambiente distendido) }\end{array}$ \\
\hline & $\begin{array}{l}12 \text { de mayo de 2015: "Així ha comencat la Mónica Terribas el debat \#MunicipalsBCN " (Foto } \\
\text { presentadora fondo candidatos) }\end{array}$ \\
\hline TV3 (/tv3cat) & 12 de mayo de 2015: "Al control de realització del debat \#MunicipalsBCN " (Foto back) \\
\hline
\end{tabular}

Fuente: Elaboración propia 
Tabla 9. Reacciones post Instagram

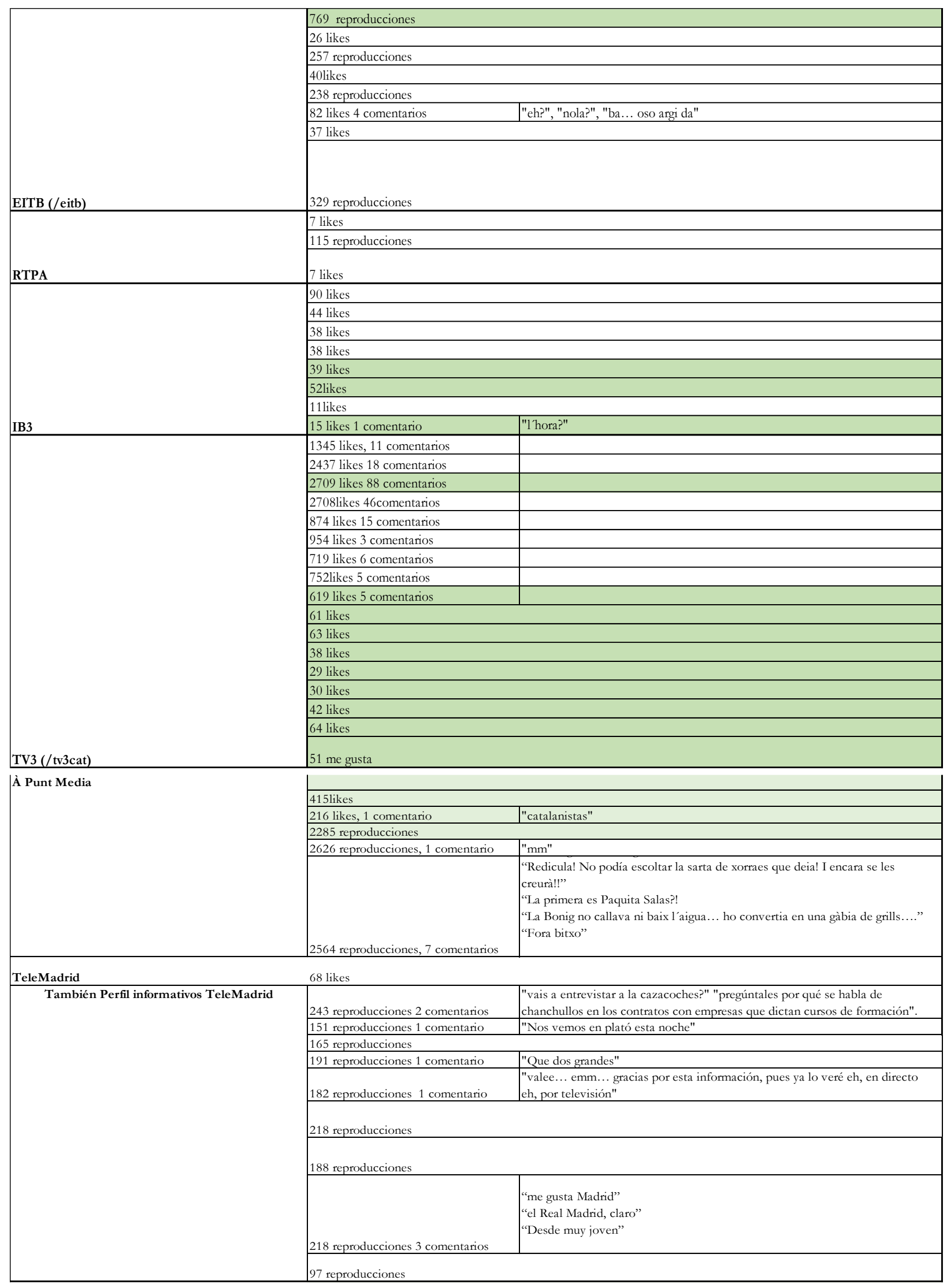


A pesar de que todos permiten comentarios en abierto, no existe diálogo, encontramos usuarios que "regalan" likes (aunque un número reducido), como muestra de reacción sin opinión.

\section{Conclusiones}

Aunque Instagram y YouTube son las redes con más usuarios y con mayor crecimiento, ambas presentan escasa atención y cuidado en los perfiles las televisiones públicas de la Federación de Organismos de Radio y Televisión Autonómicos (FORTA). Los canales no aprovechan los recursos que ambas plataformas ofrecen para crear diálogo con los usuarios y no siguen una estrategia de comunicación previa. Comprobamos además que no hay una frecuencia establecida en cuanto la publicación en sus muros, sino que cada cadena lo hace sin un orden establecido sin responder a un criterio previamente establecido.

En el caso de Instagram, el canal IGTV (aunque de reciente implementación, en 2018) está prácticamente desaprovechado aun presentándose como televisión a la carta y no de contenido aleatorio, y proponiendo resultados relacionados con lo que se está visionando. Lo mismo sucede con las instrahistories destacadas, o el recurso de vídeo como post en perfil que simplemente se emplean como elemento de promoción de la programación de la cadena. Para YouTube, se desaprovecha la posibilidad de crear comunidades y la viralización de vídeos, convirtiéndose esta plataforma en una simple hemeroteca de las retransmisiones televisivas.

En el caso de los debates electorales autonómicos, las cadenas de TV públicas se alejan en ambas plataformas de los principios dialógicos propios de las redes sociales, fundamentalmente el referido al mantenimiento del bucle dialógico (oportunidad de los usuarios de plantear preguntas y generar feedback). Estamos ante un discurso unidireccional que se distancia de la bidireccionalidad propia de estas plataformas y de su esencia característica, y que se desvincula del debate entre candidatos y audiencias; los mensajes y los públicos no son proactivos, por lo tanto, hay una carencia pronunciada de 
comunicación interpersonal colectiva y ambas redes se convierten en un mero medio de comunicación más que los usuarios pueden consultar.

El análisis de la actividad de los perfiles muestra por lo tanto que se desperdician las posibilidades que estas redes visuales ofrecen en cuanto a método para crear debate político, sea a través del mismo debate televisado, como a través de publicaciones con contenido político, a pesar de ser medios que permiten manifestar afinidad o descontento con quienes se suben a la palestra.

Desde el punto de vista audiovisual las imágenes/vídeos recogidos se centran en lo superfluo del contenido tratado (sets, candidatos posando para tomar la fotografía y promoción de entrevistas/debate) lo que también contradice la utilidad de la información aportada en el post. En relación a esto, el contenido de las publicaciones también es en su totalidad descriptivo, sin profundizar en la información recabada; aunque en todas ellas sí se hace uso de hashtags y menciones, lo que favorece la creación de vínculos entre los usuarios que lo emplean.

Los recursos audiovisuales pueden contribuir a humanizar y a mostrar la cara más amable de candidatos y partidos, pero las televisiones públicas autonómicas no las emplean en ninguna de las redes sociales analizadas con dicho fin, sino como autobombo de los propios canales.

En cuanto a los comentarios de los post, los usuarios concentran su atención en mostrar su opinión con toques de humor o en calificar el comportamiento, actitudes y actuación de los políticos, sin prestar especial atención a las temáticas abordadas a pesar de la diferente relevancia y repercusión que puedan tener (por ejemplo, el conflicto catalán).

Los canales autonómicos de la FORTA están presentes y entienden la necesidad de formar parte de estas redes audiovisuales, pero no siguen patrones activos que generen contenidos relativos al debate político, 
así como no mueven a la participación ni las emplean como instrumento para conocer mejor a sus audiencias.

En definitiva, como televisiones de servicio público deben hacer un esfuerzo por adaptarse al nuevo panorama de los medios sociales, por lo que precisan desarrollar estrategias eficientes que consigan un posicionamiento óptimo de sus contenidos dando un impulso al debate y a asuntos que respondan a los intereses de la ciudadanía.

\section{Bibliografía}

Berrocal, S., Campos, E., y Redondo, M. (2012). "Comunicación Política en Internet: La tendencia al "infoentretenimiento" político en "YouTube". Estudio sobre el mensaje periodístico 18(2), 643-659

Calvo-Porral, C., Martínez-Fernández, V.A. y Juanatey-Boga, O. (2014). "La credibilidad de los medios de Comunicación de masas: una aproximación desde el Modelo de Marca Creíble”. Intercom-RBCC, 37(2), 21-49.

Castells, M. (2009). Comunicación y poder. Barcelona: Editorial UOC.

Dader, J. L., Campos-Domínguez, E. (Coords.) (2017). La búsqueda digital del voto. Cibercampañas electorales en España 2015-16. Valencia: Tirant lo Blanch.

Esteinou, J. (2017). "Los medios electrónicos". Anuario de Investigación de la Comunicación. CONEICC, 24, 31-52.

Fernández, M. M., Sánchez Amboage, E. y Toural, C. (2018). "Las radiotelevisiones públicas europeas en el entorno web”. Revista Latina de Comunicación Social, 73, 911-923.

Giansante, G. (2014). La comunicazione politica online. Come usare il web per costruire consenso e stimolare la partecipazione. Roma: Carocci.

Hendricks, J. A., y Denton, R. E. (2010). Communicator-In-Chief: How Barack Obama Used New Media and Technology to Win the White House. Lanham: Lexington Books.

Kreiss, Daniel (2014). "Seizing the moment: The presidential campaigns' use of Twitter during the 2012 electoral cycle". New media \& society, 18(8), 1473-1490. 
López-García, G. (2016). "News vs old'leaderships: the campaign of Spanish general elections 2015 on Twitter". Communication \& Society, 29(3).

López-Rabadán, P., López-Meri, A. y Doménech-Fabregat, H. (2016). "La imagen política en Twitter. Usos y estrategias de los partidos políticos españoles”. Índex Comunicación, 6, 165-195.

Lozano-Aguiar, L. y García-Orosa, B. (2017). “Análisis comparativo de los mensajes de Twitter durante los debates televisados en las elecciones generales en España en 2015 y 2016". Teknokultura, 209-239.

Mazzoleni, G. y Schulz, W. (1999). "Mediatization of politics: A challenge for democracy". Political communication, 16(3), 247-261.

McNair, B. (2006). Cultural Chaos: Journalism and Power in a Globalised World. New York: Routledge.

Quevedo-Redondo, R. y Portalés-Oliva, M. (2017). "Imagen y comunicación política en Instagram. Celebrificación de los candidatos a la presidencia del gobierno". El profesional de la información, 26(5), 916-927.

Rúas-Araujo, J., Fernández-Holgado, J. y Alén-Amil, J.A. (2018). “La regulación de los debates electorales en el servicio audiovisual público". En Debates sobre valores e indicadores del servicio audiovisual público en Europa. Cuadernos Artesanos de Comunicación, cac 142. La Laguna (Tenerife): Latina, 79-96.

Selva-Ruiz, D. y Caro-Castaño, L. (2017). "Uso de Instagram como medio de comunicación política por parte de los diputados españoles: la estrategia de humanización en la "vieja" y la "nueva" político. El profesional de la información, 26(5), 903-915.

Vaccari, C., Chadwick, A. O'Loughlin, B. (2015). "Dual Screening: the Political Media Events, Social Media and Citizen Engagement". Journal of Communication, 65, 1041-1061.

\subsection{Otros documentos}

IAB Spain. (2018). “Estudio Anual de Redes Sociales 2018”. Disponible en https://iabspain.es/estudio/estudio-anual-de-redes-sociales2018/ a 20 de enero de 2018. 
Statista. (2018). "Las redes sociales en España". Disponible en https:/ / es.statista.com/estudio/32641/las-redes-sociales-enespana-dossier-statista/ a 15 de febrero de 2019.

Teledetodos, (2015). Bustamante, E. (coord.). "Un nuevo modelo para un tiempo nuevo. España, 2015: diagnóstico del servicio público de radio, televisión y servicios interactivos. Propuestas para una ciudadanía democrática” Disponible en: http://teledetodos.es/index.php/dictamen-2015 a 12 de febrero de 2019.

\section{Reconocimiento de la investigación}

Este capítulo forma parte de los trabajos desarrollados en el marco del proyecto de I+D+I (Retos) "DEBATv, Debates Electorales Televisados en España: Modelos, Proceso, Diagnostico y Propuesta" (Ref. CSO2017-83159-R), financiado por el Ministerio de Economía, Industria y Competitividad (MINECO), la Agencia Estatal de Investigación (AEI) y el Fondo Europeo de Desarrollo Regional (FEDER) de la Unión Europea (UE). 


\title{
13 \\ Formato televisivo y proyección en Twitter de las elecciones en Andalucía
}

\author{
Concha Pérez-Curiel \\ Universidad de Sevilla \\ Mar García Gordillo \\ Universidad de Sevilla
}

\begin{abstract}
PARA CITAR: Pérez-Curiel, C. y García Gordillo, M. (2019). "Formato televisivo y proyección en Twitter de las elecciones en Andalucía". En Conde-Vázquez, E., Fontenla-Pedreira, J. y Rúas-Araújo, J. (Eds.), Debates electorales televisados: del antes al después (pp. 257-282). Cuadernos Artesanos de Comunicación, cac154. La Laguna (Tenerife): Latina. DOI: $10.4185 / \operatorname{cac} 154$
\end{abstract}

\section{Resumen}

Los resultados de las elecciones celebradas en Andalucía (2D) han sorprendido a vencedores y vencidos. Ni las encuestas, ni los debates ni las propias redes sociales vaticinaban el vuelco electoral provocado por la irrupción en el Parlamento de Vox, un partido definido como "ultraderecha" que ahora es "llave del cambio", tras casi cuarenta años de Gobierno Socialista. En este contexto, el "debate televisado", previo a las elecciones, se pone en entredicho. Políticos, medios y audiencias cuestionan un formato, sometido a un tiempo y a un espacio rígido, que limitan el proceso de información, comunicación y captación del interés público. Un modelo lento y distante, comparado con la velocidad e interacción de los mensajes en red. Investigar en qué medida los debates emitidos durante la campaña de las elecciones andaluzas (Canal Sur y TVE), suponen una fuente de información 
electoral relevante, analizar las estrategias de comunicación verbal de los candidatos y comprobar el seguimiento de usuarios en Twitter, son objetivos del estudio.

Sobre una muestra que recoge las fechas de ambos debates (19 y $26 \mathrm{~N}$ ) se aplica una metodología triangulada de análisis de contenido comparado (nivel cuantitativo, cualitativo y discursivo). Las variables diseñadas miden los temas tratados por los candidatos de los partidos con representación parlamentaria (PSOE, PP, Ciudadanos y Adelante Andalucía), así como la proyección que los debates televisados alcanzan en la red (métricas de usuarios en cada una de las cuentas personales de los políticos) y la posible relación de equivalencia con el número de votos en los comicios. Además, se analiza el perfil de Vox en Andalucía, un partido que, sin representación parlamentaria, alcanza protagonismo mediático -y sobre todo digital- con viralización máxima del mensaje del candidato, siendo foco de atención del debate televisado.

Los resultados invitan a reflexionar sobre un modelo desfasado, minutado, centrado en el "y tú más" y en visualizar las tendencias populistas e independentistas y el pacto electoral, como claves de confrontación del discurso. Frente a la capacidad de los nuevos formatos digitales para configurar, a golpe de tuit, el nuevo mapa político de la comunidad, los políticos han protagonizado un discurso más proyectado hacia las elecciones generales que a los temas de interés público para Andalucía, sin programa ni propuestas para los ciudadanos. Sólo un punto en común: el discurso de lo fake y la desinformación como emblema de una sociedad que se denomina "avanzada".

Palabras clave: debates televisados, comunicación política, elecciones andaluzas, twitter, análisis de contenido.

\section{Introducción. Redefinición del debate electoral televisado. Una cuestión de urgencia}

L debate, como estrategia electoral, sigue ocupando una parte
primordial de la agenda de políticos y medios. A pesar de no estar 
demostrados sus efectos en la decisión del voto ciudadano, se constituye como una herramienta clave del proceso previo a las elecciones (Galindo Arranz y Regueira Rey, 2018).

La televisión se ha postulado como el medio por excelencia para los debates, aunque hoy, las redes sociales marcan un nuevo escenario, que indiscutiblemente hay que tener en cuenta. El debate político en TV se mantiene como formato de información de campaña. Desde el "cara a cara" entre Nixon y Kennedy en 1960 se han visto numerosos debates televisados en campaña electoral en todo el mundo. En sus distintas modalidades (cara a cara, tertulia o "a cuatro", en relación al número de candidatos), se define como fórmula política que funciona, aunque con un futuro incierto.

Urge una reflexión sobre la efectividad de este instrumento político, especialmente en el marco de la televisión pública (sin descartar las cadenas privadas) y de las instituciones políticas gubernamentales.

La investigación propone como objetivos conocer el desarrollo de los dos debates organizados por televisiones públicas (Canal Sur y TVE) durante la campaña de las elecciones en Andalucía (2 D, 2018), analizar el contenido y el enfoque temático y la actitud de los candidatos y comprobar la reacción de los públicos en las redes sociales. El debate en primera ronda $(19 \mathrm{~N})$ y en segunda $(26 \mathrm{~N})$ reproduce de nuevo un producto que no justifica el coste añadido en el ámbito de lo público, se centra en la personalización del candidato, no aporta información de interés, propuestas de gestión o revisión crítica y argumentada de los incumplimientos, tanto de partidos del Gobierno como de la oposición y por tanto, no cumple con el objetivo primario en política: garantizar el éxito electoral.

Los debates políticos en televisión necesitan una reforma en sus estructuras, contenidos y formas de programación. Los nuevos retos de la comunicación y el periodismo audiovisual en televisión exigen renovar esquemas que se repiten periódicamente. Al no haber ninguna regulación ni una tradición establecida, el debate electoral en televisión queda en un gesto de posible buena voluntad entre los participantes y los organizadores (Casado Ruiz, 2012). 
Las audiencias mandan. Si la cuota de pantalla de estos debates ${ }^{50}$ no manifiesta el interés de la opinión pública, habrá que dilucidar sobre las múltiples razones (comportamiento del candidato, temática, organización del espacio, distribución de los tiempos, actitud del moderador, hora de emisión, proyección en paralelo en redes y seguimiento y difusión en días posteriores a la celebración, entre otros aspectos) que inducen a pensar en un modelo de comunicación política en crisis. No dejarlo morir significa diseñar un formato que se adapte a los nuevos tiempos, con unos contenidos que ofrezcan respuesta a las verdaderas preocupaciones ciudadanas.

\section{Confluencia de encuadres y contextos}

Independientemente de cuestiones relativas a los procesos de negociación, producción y emisión de los debates como género televisivo y político, la clave principal del estudio se relaciona con el poder de la comunicación política centrada en los representantes máximos de cada partido (sujeto), en el empoderamiento y la capacidad para la propaganda y la manipulación que concentra la televisión como medio (objeto) y la causalidad y consecuencias para los receptores off y online (opinión pública).

El background de la investigación requiere consultar literatura científica sobre:

- Teorías de la influencia de los media en la sociedad y la relación entre el poder mediático y el político. Los estudios revelan unos efectos limitados en función de múltiples factores (edad, sexo, formación y contexto político-económico, entre otros).

- Relación entre televisión y poder. Procede una revisión de los debates televisados en Estados Unidos y Europa, por

\footnotetext{
${ }^{50} \mathrm{El}$ debate emitido por Canal Sur $(19 \mathrm{~N})$ alcanza un $13 \%$ de cuota / 431.000 espectadores en Andalucía y 0,5\% de cuota / 13.000 espectadores en la emisión de La Otra, segunda cadena de Telemadrid. El debate emitido por TVE (26N) congregó a 395.000 espectadores y un 12,3 \% de cuota en su emisión simultánea en La 1 y Canal 24 Horas en Andalucía.
} 
considerarse como referentes para el caso español y andaluz. Un marco en el que se investigan factores como el rol de las instituciones organizadoras, el formato, la moderación, la puesta en escena, la programación, el calendario, las condiciones técnicas y, especialmente, el análisis de los actores políticos participantes en la contienda, --candidatos y equipos-- y qué temas tratan, cómo y por qué.

-Contexto político del debate. Las elecciones suponen un acontecimiento extraordinario, con una fase previa (campaña) y post (definición del gobierno, alianzas, pactos, presentación ante los medios de nuevos o viejos gestores).

-Contexto mediático, que englobe los antecedentes relativos a los primeros debates televisados, características tanto en cadenas públicas como privadas, proyección del formato audiovisual en Internet (plataformas de Televisión Digital Terrestre) y análisis de nuevos consumidores.

-Tipología del debate, con objeto de comprobar qué modalidad logra mayor éxito. Las condiciones políticas y mediáticas auguraban el regreso de los debates cara a cara entre candidatos a la presidencia, tras años de ausencia, pero la inmersión de los partidos emergentes en España (Ciudadanos y Podemos) ha alterado la radiografía del cara a cara, propia de un bipartidismo afianzado, y pondera la fuerza del debate a cuatro, en atriles, con limitación de movimientos y con la posibilidad de mirar directamente a cámara, que más que cercanía con el ciudadano, puede generar autoritarismo, manipulación y presión en los receptores. Ante los debates de 2008, se produjo a nivel nacional una intensa negociación entre las televisiones para su emisión. La solución pasaba por distribuir una señal única (Academia de la TV) para todos los medios interesados.

-Contexto digital, como dinamizador de un nuevo perfil de consumidor, que usa likes, retweets y comentarios, capaz de hacer viral y convertir en trending topic un tema, por acierto- pero también por error, que dada la velocidad del mensaje es difícil corregir antes de que produzca efectos nocivos. 
Las redes tienen un potencial extremo para la comunicación y el marketing político- pero a su vez, suponen un reto y un riesgo para gobiernos, partidos y medios. En el seno de lo digital el mal uso de los recursos (enlaces, hashtags, vídeos, fotos, emoticonos, memes...) y la ausencia de interacción con el usuario (unidireccionalidad frente a bidireccionalidad) pasan factura política; en el plano de los medios, y tras la evidencia del éxito de difusión de los mensajes en red, el peligro reside en copiar el modelo y proyectar los contenidos que decide el político y viraliza el usuario, sin respetar los códigos básicos de responsabilidad periodística (Pérez-Curiel y García-Gordillo, 2018).

Desde la aparición de la televisión, los debates electorales entre candidatos a la presidencia del Gobierno se han convertido en hitos de la historia de la comunicación política en aquellos países donde se celebran. Estos eventos han sido un indicador del grado de desarrollo de las democracias modernas. Hipótesis que se tambalea en el momento político actual, abanderado por lo digital, dominado por la incorporación de los partidos emergentes y cuestionados por una ciudadanía que representa el hartazgo al establishment. En el mundo, el triunfo de Trump en las elecciones americanas (PérezCuriel y Limón Naharro, 2019; Rúas Araujo, Mazaira y Rodríguez Vázquez, 2018), en Europa, el avance de los populismos, (AlonsoMuñoz y Casero-Ripollés 2019; Rodríguez Sáez, 2018), en España, la corrupción política y las diferencias Estado/Autonomías (Carrasco Polaino, Villar Cirujano y Tejedor Fuentes, 2018) y en Andalucía, la eternización en el poder de un gobierno socialista (Pérez-Curiel, 2019) son ejemplos que provocan una reacción social contra la política y sus líderes.

El debate en televisión, a diferencia de los resultados de audiencia de sus mejores años, ha aumentado la reacción de negatividad e indiferencia de una ciudadanía que impone nuevas formas de comunicación, de información y de opinión, al menos para los públicos más jóvenes. Los formatos tradicionales viven un momento delicado- aunque su supervivencia pasa por responder con más 
calidad a un perfil de generaciones adultas, fieles a la televisión, pero cada vez más poseídas por el innegable influjo de las redes.

\section{El debate en Andalucía. Preámbulos de cambio político}

El adelanto de elecciones en Andalucía, anunciado por la presidenta de la Junta, Susana Díaz (PSOE) en un contexto que los partidos de la oposición han vinculado al juicio ERE y a la ruptura del pacto con Ciudadanos -partido que posibilitó la gobernanza política socialistano parece haber provocado los resultados esperados. La intromisión de Vox, referente del populismo y la extrema derecha, ha supuesto una carta no contemplada inicialmente en el escenario electoral ${ }^{51}$. Un condicionante que dibuja una etapa de cambio, liderada por el pacto entre los partidos conservadores y apoyados por un frente populista. Según Xavier Coller, sociólogo, "el conflicto de la inmigración, los efectos devastadores de la crisis económica, el descontento con los partidos tradicionales, la corrupción y la radicalización de la política por bloques son posibles causas del triunfo del populismo de Vox"52.

Dos debates entre los candidatos a la Presidencia de la Junta de las cuatro formaciones con representación parlamentaria, Susana Díaz (PSOE), Juan Manuel Moreno (PP), Teresa Rodríguez (Adelante Andalucía) y Juan Marín (Ciudadanos), son los protagonistas de los previos electorales tal y como había avanzado el Consejo de Administración de la RTV A en la aprobación del plan de cobertura para las elecciones andaluzas. Emitidos por Canal Sur $(19 \mathrm{~N})$ y por TVE (26N), responden a cánones fijos, una estructura cerrada, con atriles y un crono regulado por árbitros deportivos, una cuestión que no convence porque limita la exposición, diálogo y análisis de los asuntos que preocupan al público.

\subsection{Los temas del debate off y on}

Cuatro serán los bloques establecidos: a) Empleo, Economía y Política Fiscal; b) Servicios públicos esenciales y Derechos básicos; c)

\footnotetext{
${ }^{51}$ http:/ / theconversation.com/vox-y-voto-shock-en-andalucia-109519

52 https://www.huffingtonpost.es/2018/10/07/la-extrema-derecha-ya-estaaqui-hasta-donde-puede-llegar-vox_a_23552333/
} 
Transparencia y confianza en la vida pública; y, d) Reto territorial y Andalucía en el estado de las autonomías.

Algunos de los nombres de los bloques pueden parecer abstractos, pero son los partidos quienes deciden conceptos amplios para que se puedan exponer varios asuntos dentro del mismo bloque. Se desglosan temas específicos como independentismo, populismo, política de pactos, corrupción, presupuesto, impuestos, pensiones, educación y sanidad y desempleo, entre otros.

\section{Imagen 1.}

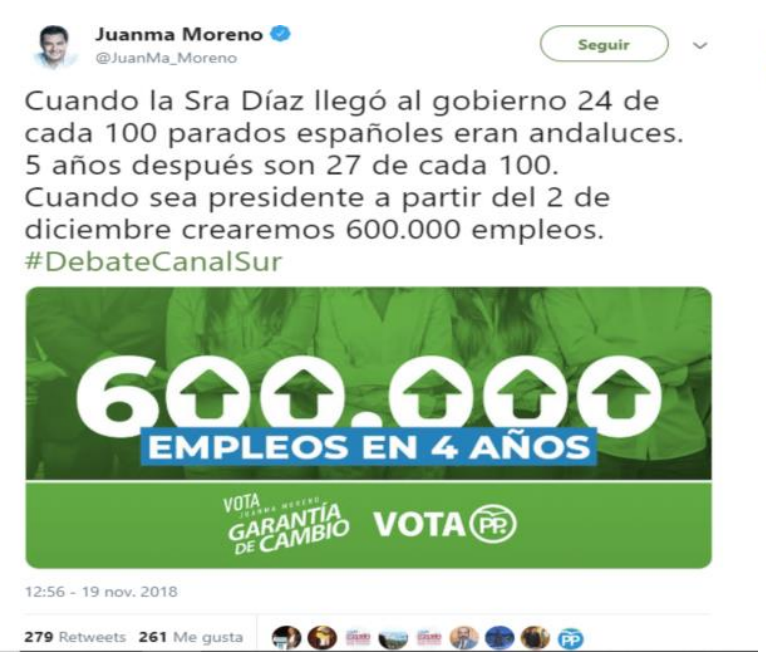

\section{Imagen 2.}

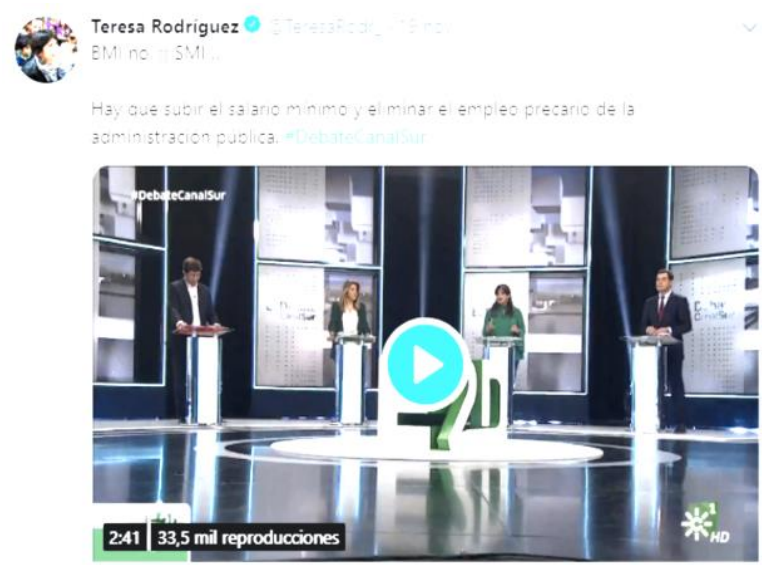

Mas salario mínimo

Fuente: Twitter

En Twitter se produce una proyección temática derivada del debate televisado. Partidos y candidatos usan esta plataforma como trampolín viral que reproduce el mensaje de manera instantánea, directa y persuasiva, con un objetivo común: conseguir el voto electoral.

\subsection{Datos de audiencia. Decide la Red}

Entre la comunidad científica existe consenso en la caracterización de los debates como una actividad que concentra la atención de los medios y eclipsa otras actividades de campaña, produciendo mucha información mediada (Canel, 2008). En esta línea, los ítems de audiencia son similares a los conseguidos por programas de entretenimiento de máxima expectación (Druckman, 2003) debido a su configuración como política-espectáculo al estilo estadounidense, y a que permiten observar a los candidatos en un enfrentamiento 
espontáneo y natural sin que cuenten con el respaldo mayoritario del público, como sucede en los mítines y actos de partido, en los que "la adhesión de los incondicionales hacia los líderes que intervienen se da por supuesta" (Salvador i Liern, 2008).

En Andalucía, los datos de audiencia del primer debate (13\% de cuota y 431.000 espectadores en Canal Sur) contrastan con los conseguidos en segunda ronda el $26 \mathrm{~N}$ (12,3\% de share y 395.000 espectadores) en su emisión simultánea para toda España en TVE, (Canal 24 Horas y Radio 5). En general, los públicos más fieles al debate muestran un desencanto hacia los políticos, critican la falta de propuestas de gobierno y el discurso fake, que favorece la televisión y aumenta la red.

La revolución digital marca hoy las pautas en el campo de las instituciones públicas y privadas y de los medios y determina el consumo de información. Ver el debate exclusivamente a través de la televisión responde a una actitud obsoleta. Los expertos califican al «prime time» televisivo como horario de consumo de información «de segunda pantalla» ya que, en paralelo, los espectadores consultan Internet, a través del móvil o de la tablet. Esto no es ningún secreto para los políticos y sus equipos. De hecho, las formaciones políticas diseñan una estrategia igual de trabajada para las redes sociales. Por tanto, el seguimiento del debate televisado va supeditado, incrementado y superado por las reacciones de un tripartito-político, medios y ciudadanos- con presencia digital asegurada.

El uso de Twitter es especialmente intenso en los períodos de campaña. Desde las elecciones norteamericanas de 2008, con Barack Obama, la influencia de esta plataforma sobre la comunicación política no ha parado de crecer (Bimber, 2014). Twitter se convierte en escenario para la difusión (Jackson; Lilleker, 2011), interacción (Engesser; Fawzi; Larsson, 2017), movilización (Gainous, 2014) y personalización del líder (Vergeer; Hermans; Sams, 2013). En Twitter, los candidatos aplican una doble estrategia: publican mensajes autopromocionales en un tono positivo, complementados con críticas al adversario. Y la red, además, ofrece la oportunidad de captar el voto joven, una audiencia habitual, experta en viralizar y multiplicar los efectos del mensaje. 


\section{Metodología}

A partir de un método de análisis de contenido comparado de doble enfoque (cuantificación y cualificación) se analizan los dos debates televisados, celebrados con anterioridad a las elecciones (2D) en Andalucía, su proyección en redes y su efecto en los ciudadanos. Dos cadenas públicas, Canal Sur $(19 \mathrm{~N})$ y TVE $(26 \mathrm{~N})$ retransmiten en directo y prime time $(21,30)$ el debate, una herramienta clave en campaña electoral, que hoy se vale de las redes sociales, plataformas virales que captan la máxima atención de los consumidores en Política.

Se diseña una ficha de medición de variables:

1.- Variables cuantitativas-numéricas

2.- Variables cualitativas-temáticas

Ambos grupos de variables, aplicadas a modelos off (TV) y on (Twitter) se analizan también desde la perspectiva del uso que los candidatos realizan de Twitter. El mensaje publicado en red cobra mayor intensidad cuando se apoya en links, vídeos, hashtags, memes o imágenes, pero fundamentalmente cuando se produce interactividad entre políticos y usuarios.

La muestra incluye los debates seleccionados (Canal Sur y TVE) y las métricas (Me gusta, RT y Comentarios) de las cuentas personales en Twitter de los candidatos de partidos con representación parlamentaria @ susanadiaz del PSOE, @JuanMa_moreno del PP, @JuanMarin_Cs de Ciudadanos y @TeresaRodr- de Adelante Andalucía). PP y PSOE representan a la política del bipartidismo más tradicional frente a Ciudadanos y Adelante Andalucía, considerados como partidos emergentes, que representan un modelo de hacer política y de captar votantes diferente al establecido y que han encontrado en las plataformas digitales un recurso para su consolidación, entre los grupos de población más jóvenes o entre los electores descontentos con la gestión política de sus propias formaciones (ya sea en modo "oposición" o en modo "gobierno"). 
Tabla 1. Ficha de variables generales

\begin{tabular}{|c|c|c|c|c|c|}
\hline TV & Partidos & Candidato & $\begin{array}{c}\text { Métricas } \\
\text { (me gusta, RT, } \\
\text { Twitter }\end{array}$ & $\begin{array}{c}\text { Temática } \\
\text { e }\end{array}$ & $\begin{array}{c}\text { Recursos } \\
\text { Online }\end{array}$ \\
\hline
\end{tabular}

Fuente: Elboración propia

Dado el impacto en el contexto de las elecciones andaluzas de un partido como Vox, sin representación parlamentaria, y dada la relevancia que los candidatos de otros partidos le brindan en los debates (especialmente en el emitido por TVE), se analizan también las métricas del líder de esta formación en Andalucía (@FSerranoCastro) en Twitter a fecha de muestreo.

Tabla 2. Ficha de Bloques Cuantitativos y Cualitativos

\begin{tabular}{|l|l|l|l|}
\hline $\begin{array}{l}\text { Variables } \\
\text { cuantitativas }\end{array}$ & $\begin{array}{l}\text { Variables temáticas } \\
\text { generales }\end{array}$ & $\begin{array}{l}\text { Variables temáticas } \\
\text { específicas }\end{array}$ & $\begin{array}{l}\text { Recursos } \\
\text { (Twitter) }\end{array}$ \\
\hline $\begin{array}{l}\text { Número de } \\
\text { Tweets }\end{array}$ & $\begin{array}{l}\text { Empleo, Economía y } \\
\text { Política fiscal }\end{array}$ & $\begin{array}{l}\text { Presupuestos } \\
\text { Desempleo } \\
\text { Recortes en Sanidad } \\
\text { y Educación } \\
\text { Pensiones }\end{array}$ & Vídeos \\
\hline $\begin{array}{l}\text { Número de } \\
\text { Me Gusta }\end{array}$ & Servicios públicos & $\begin{array}{l}\text { Infraestructuras } \\
\text { Dependencia } \\
\text { Violencia de Género } \\
\text { Autónomos } \\
\text { Taxi }\end{array}$ & Imágenes \\
\hline $\begin{array}{l}\text { Número de } \\
\text { Retweets }\end{array}$ & $\begin{array}{l}\text { Transparencia y } \\
\text { confianza en la vida } \\
\text { pública }\end{array}$ & $\begin{array}{l}\text { Corrupción } \\
\text { Seguridad } \\
\text { Bienestar Social } \\
\text { Sostenibilidad }\end{array}$ & Links \\
\hline $\begin{array}{l}\text { Número de } \\
\text { Comentarios }\end{array}$ & $\begin{array}{l}\text { Reto territorial y } \\
\text { Andalucía en el estado } \\
\text { de las autonomías. }\end{array}$ & $\begin{array}{l}\text { Unidad de España } \\
\text { 155 } \\
\text { Independentismo } \\
\text { Estado plurinacional } \\
\text { Autonomías } \\
\text { Unión Europea }\end{array}$ & Hashtags \\
\hline & $\begin{array}{l}\text { Asuntos de interés } \\
\text { electoral }\end{array}$ & $\begin{array}{l}\text { Política de Pactos } \\
\text { Populismos }\end{array}$ & Memes \\
\hline & & & \\
\hline
\end{tabular}


\begin{tabular}{|l|l|l|l|}
\hline & Vox & \\
\hline
\end{tabular}

Fuente: elaboración propia

Atendiendo al número de tweets publicados desde la cuenta personal de cada uno de los candidatos presentes (debates del 19 y el $26 \mathrm{~N}$ ), sumados a los tweets publicados por Vox, se van a analizar un total de 101 tweets, 37.255 me gusta, 25.518 retweets y 3.223 comentarios, respectivamente.

Tabla 3. Comparativa de Métricas en Twitter por candidato

DEBATES 19 Y 26 NOVIEMBREEN TWITER (Ud.)

\begin{tabular}{|c|c|c|c|c|c|c|c|c|}
\hline & TWEETS D/A 19 & ME GUSTA DLA 19 & RETWEETS DA 19 & COMENTARIOS DLA 19 & TWEETS Dla 28 & ME GUSTA DLA 28 & RETWEETS DLA 2B & COMENTARIOS DLA2B \\
\hline SUSANA DUZZ & 3 & 1281 & 795 & 240 & 3 & 1188 & 700 & 587 \\
\hline JUANMA MOAENO & 21 & 8520 & 4900 & 482 & 31 & 442 & 2052 & 110 \\
\hline JUAN MABilN & 2 & 30 & 271 & 15 & 6 & 2050 & 1328 & 224 \\
\hline TERESA ROORIGUEZ & 18 & 12716 & 8006 & 制 & 10 & sel1 & 4928 & 543 \\
\hline RAMON SERRANO & 3 & 456 & 272 & 12 & 7 & 2410 & 1240 & 133 \\
\hline TOTAL & 45 & 20308 & 15024 & 1028 & 86 & 15849 & 1044 & 1597 \\
\hline
\end{tabular}

Fuente: elaboración propia

Sobre los tweets y métricas se aplican las variables generales y específicas definidas en la metodología.

\section{Análisis de resultados}

Son múltiples las hipótesis que rodean la funcionalidad y sentido de los debates electoral televisados. Con la revolución digital, estas premisas se consolidan o por el contrario se debilitan. ¿ ¿Sigue siendo el debate una estrategia clave para determinar el voto en las elecciones? ¿Responde la estructura temática marcada al interés público? ¿Qué ha supuesto para las audiencias la posibilidad de seguir el debate a través de las redes? ¿En qué medida se cubren estos debates desde las cuentas de partidos y candidatos? ¿Las redes han contribuido a que se reduzca el interés por un formato televisivo que hasta el momento alcanzaba máxima expectación?

La tesis principal que emerge de los resultados de la investigación constata que el formato del debate en televisión no responde a las preocupaciones ciudadanas, no muestra las propuestas (programa) del 
partido, se somete a una temporalización y a un espacio restringido y se centra en el ataque y la confrontación entre líderes.

En paralelo, existe un incremento de la población (joven y adulta) que sigue los acontecimientos políticos a través de las redes y, en especial, Twitter, se convierte en una herramienta habitual para influir de manera directa en los e-usuarios. Las ventajas que encierra la red generan una reproducción instantánea y viral del mensaje, mediante likes, retweets y comentarios. El uso adecuado de los recursos que facilita la red (hashtags, links, imágenes, vídeos, memes, etc.) refuerza los contenidos e incrementa el poder del mensaje. Sin embargo, se detecta un modelo de comunicación unidireccional centrado en los líderes (sujetos) más que en los temas (objetos) y en la respuesta a los usuarios, en contraposición con la bidireccionalidad que se le supone a las redes.

El análisis de resultados se estructura en relación a tres niveles:

a) Nivel de cuantificación. Variables relacionadas con los tweets de candidatos y las métricas de los usuarios de Twitter.

b) Nivel de cualificación. Variables relacionadas con la temática de los debates televisados y proyectados en Twitter.

c) Nivel de bidireccionalidad. Variables relacionadas con el uso que los candidatos de cada partido realizan de Twitter y las estrategias y herramientas que potencian la interacción con las audiencias digitales.

El relato del análisis es por tanto trifásico y se construye a partir del posicionamiento en televisión y del seguimiento paralelo en Twitter de cada uno de los líderes políticos seleccionados para el estudio.

Es importante tener en cuenta el papel de los emisores del mensaje. Los debates se televisan en directo en distintos días y en cadenas diferentes; por tanto, los candidatos se encuentran presencialmente en la televisión, pero desde sus cuentas personales se publican tweets en tiempo real, lo que pone de relieve que son los equipos de comunicación y Dircom, los que gestionan en ese momento tanto la cuenta del partido como la cuenta del político. 


\section{a) Niveles de cuantificación}

El análisis del número de seguidores de las cuentas de los políticos y de sus partidos en Twitter, así como el número de tweets publicados por cada formación y sujeto, se constata en la siguiente tabla:

Tabla 4. Posicionamiento de partidos y candidatos en Twitter

\begin{tabular}{|c|c|c|c|c|c|c|c|c|c|c|c|}
\hline & PSOE & Díaz & PP & Moreno & Ciudadanos & Marín & AA & Rodríguez & Vox & Serrano & TOTAL \\
& & & & & & & & & & & \\
\hline SEGUIDORES & 46.000 & 174.000 & 34.700 & 57.900 & 24.900 & 1.810 & 11.300 & 309.000 & - & 22.500 & 698.400 \\
\hline TWEETS & 44.500 & 2.000 & 58.000 & 9.000 & 55.500 & 1.010 & 1.600 & 18.000 & - & 7.300 & $\mathbf{2 0 6 . 0 0 0}$ \\
\hline
\end{tabular}

Fuente: elaboración propia

De los grupos políticos con representación parlamentaria, el PSOE cuenta con mayor número de seguidores (46.000) frente a Adelante Andalucía que alcanza la cifra más baja (11.300). Estos datos se corresponden también con los resultados obtenidos en número de votos en las elecciones andaluzas (2D). Con referencia a los candidatos, se produce un vuelco, ya que Teresa Rodríguez (AA) supera con creces en número de fans (309.000) al resto de candidatos, ocupando la última posición el representante de Ciudadanos (1.810). Por número de tweets publicados por partidos, es el PP quien ocupa el primer puesto (58.000 tweets), aunque a nivel de candidatos es Teresa Rodríguez de Adelante Andalucía quien alcanza la mayoría (18.000 tweets).

Estudios previos (Pérez-Curiel y Lancharro, 2017) ponen de relieve el éxito en Twitter de las estrategias de comunicación de candidatos como Pablo Iglesias de Podemos o su homóloga en Andalucía (AA), una evidencia también en la investigación desarrollada.

El gráfico de barras indica el porcentaje de tweets publicados y de seguidores por partido y candidato. 
Gráfico 1. Presencia en Twitter (\%Partidos/\%Candidatos)

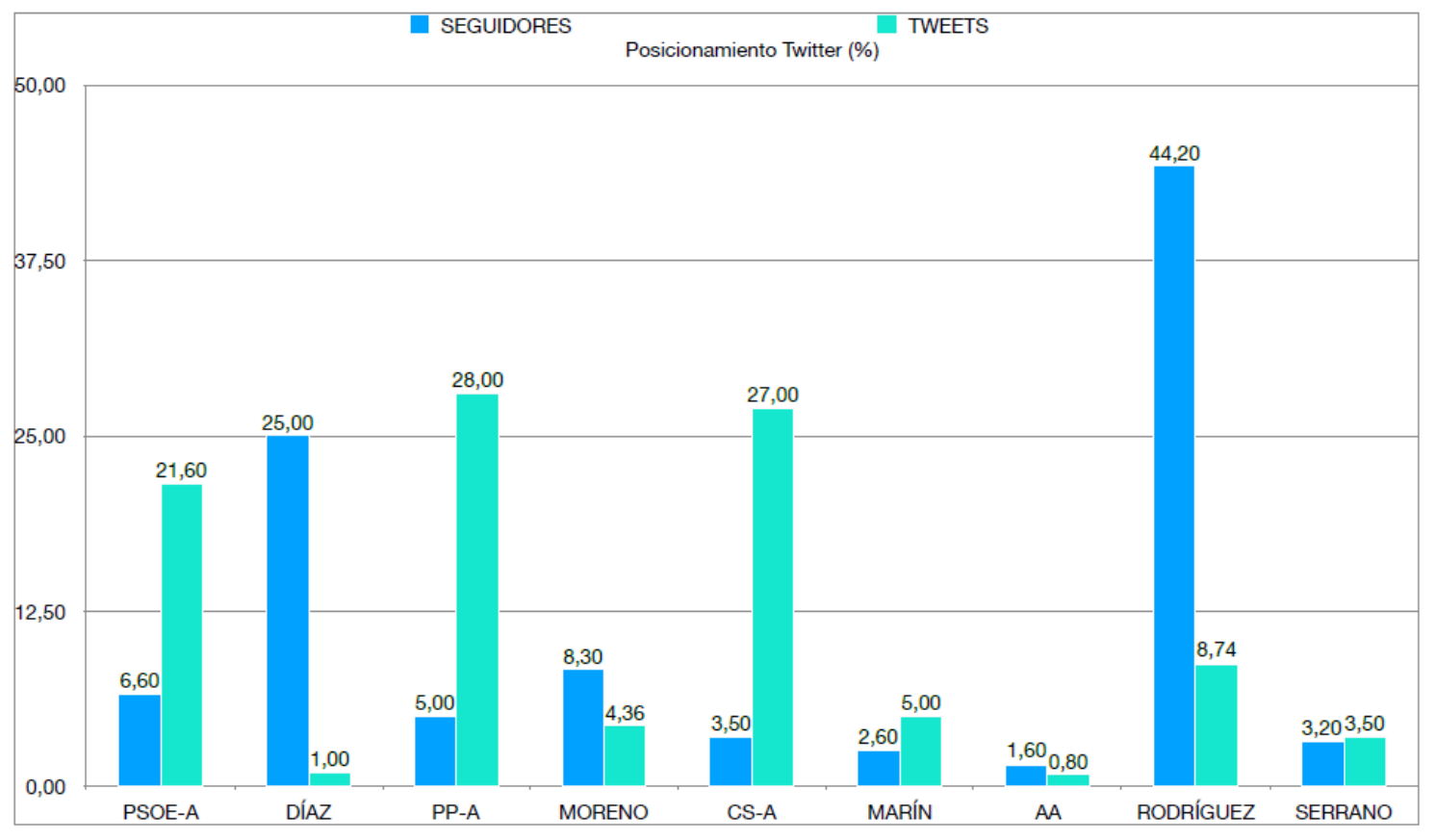

Fuente: elaboración propia

El objeto de incluir los datos de Vox-A, un partido que no contaba con representación en el Parlamento (posteriormente alcanza 12 escaños en las elecciones andaluzas), se explica por el protagonismo que como partido registra en los temas tratados durante los debates televisados. La candidata socialista lo refleja en el siguiente tweet:

En cualquier caso, el líder en Andalucía alcanza los resultados más bajos tanto en tweets publicados (7.300) como en número de seguidores (22.500), unas cifras que efectuarán un importante crecimiento en fechas próximas a la celebración de las elecciones y en el período postelectoral.

La política de pactos, propia de cualquier proceso electoral en el que ningún partido alcanza la mayoría absoluta, altera los resultados y revela la incoherencia del partido que finalmente gobierna con el partido que mayor número de seguidores alcanza en la red. En el caso concreto de Andalucía, el pacto PP/Ciudadanos, sumado al apoyo de Vox, los 
convierte en regidores del nuevo Gobierno andaluz, independientemente del posicionamiento y seguimiento de usuarios que registran por separado en Twitter.

\section{Imagen 3.}

Susana Díaz Pacheco (asusanadiaz $\cdot 26$ nov.

Salgo satisfecha de un debate en el que he planteado propuestas y respuestas para el futuro de \#Andalucía. PP y Ciudadanos no han querido contestarme, hasta en cuatro ocasiones, si se apoyarian en la ultraderecha de Vox para bloquear un gobierno socialista.

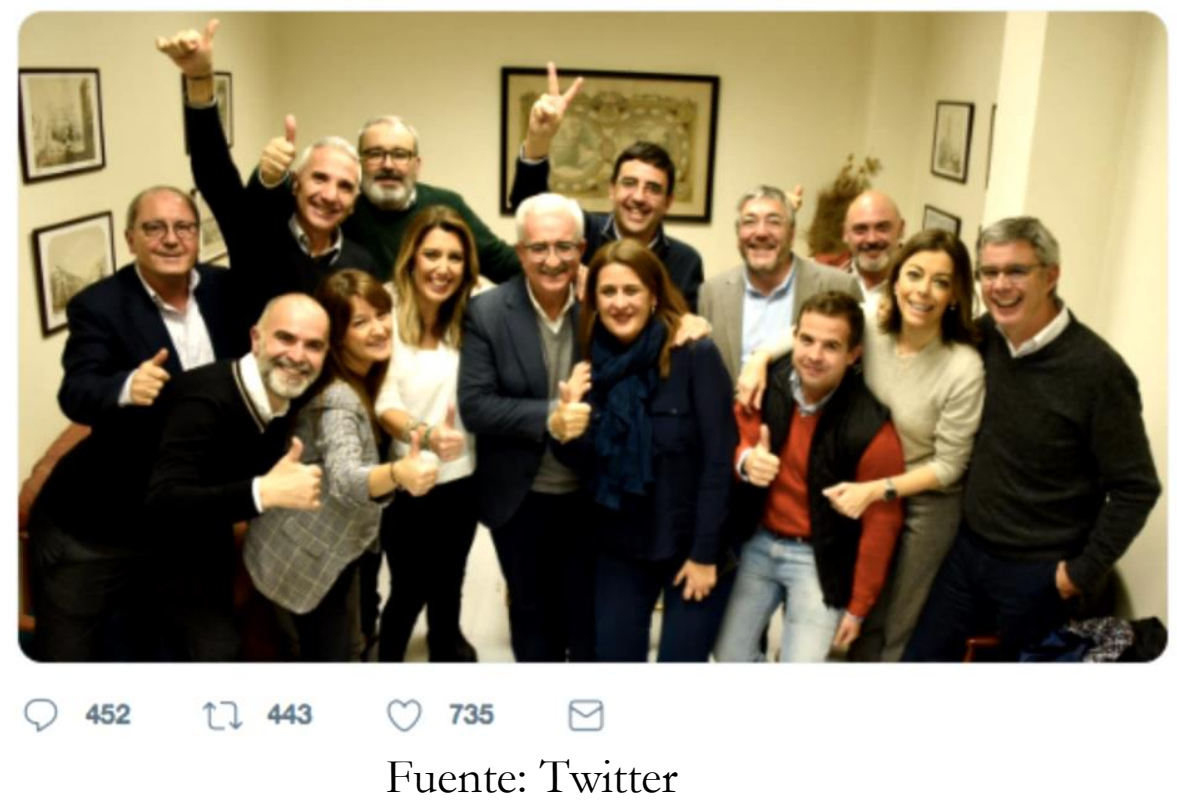

Las métricas (likes, RT y comentarios) constituyen variables de cuantificación. Se consideran factores que miden la difusión, interacción y respuesta de los públicos.

La medición se focaliza en los candidatos, como ejes motores de la red Twitter. Los datos revelan la actividad digital de cada candidato, vinculada a la emisión de los debates electorales. Relacionado con afirmaciones anteriores, en el primer debate $(19 \mathrm{~N})$ destaca el protagonismo en la red de la candidata de Adelante Andalucía (36\% de tweets) y métricas relevantes (62\% de MG, 68\% de RT y 53\% de Comentarios), seguida por Juanma Moreno del PP (46\% de tweets) y valores métricos (27\% de MG, 32\% de RT y 30\% de Comentarios), bastante diferenciados del resto de grupos 
Gráfico 2. Métricas de los debates electorales (Canal Sur y TVE)

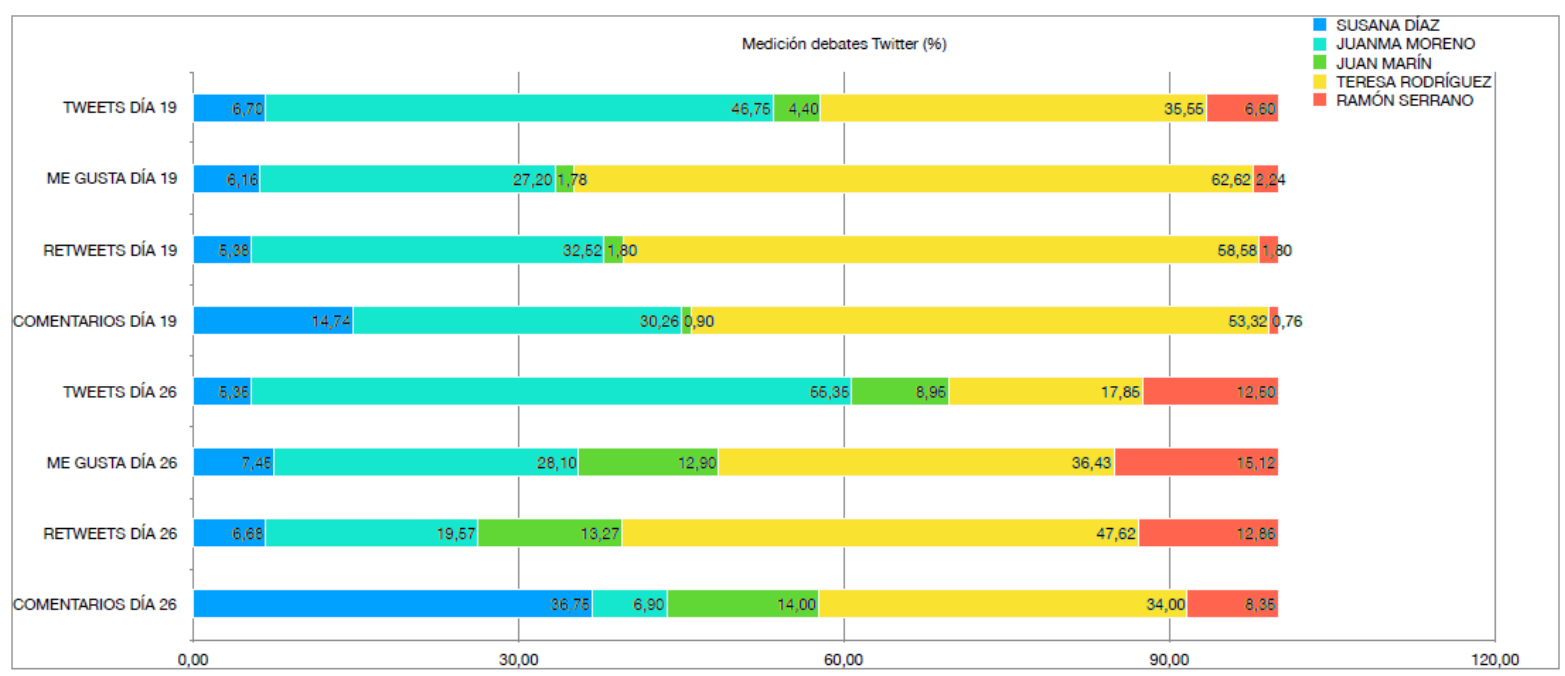

Fuente: elaboración propia

En cuanto al segundo debate $(26 \mathrm{~N})$, los porcentajes siguen siendo favorables a estos dos candidatos, incrementándose incluso el número de tweets publicados por el líder popular (66\%). Interesante observar el nivel porcentual de comentarios de los seguidores de Twitter sobre las publicaciones de los candidatos. Existe una respuesta proporcional a la actividad producida, con la excepción, en el segundo debate (26N) de los comentarios (36\%) hacia Susana Díaz, candidata del PSOE y hasta esa fecha presidenta de la Junta de Andalucía.

Se constata además que la respuesta del candidato a los usuarios es inversamente proporcional a los comentarios publicados. La falta de bidireccionalidad es una propiedad común a todos los candidatos.

\section{b) Niveles de cualificación}

El análisis de contenido aplicado al debate televisado y a las redes dibuja una radiografía temática en la que cada grupo y candidato priorizan y ponderan con valencia positiva o negativa, con el objetivo de que influyan en los resultados electorales. 
Independientemente de que el debate se estructure en bloques, se desglosa una batería de temas específicos, que toman mayor o menor relevancia en orden a la ideología y discurso de los líderes.

Gráfico 3. Líneas temáticas y focos centrales comunes a ambos debates

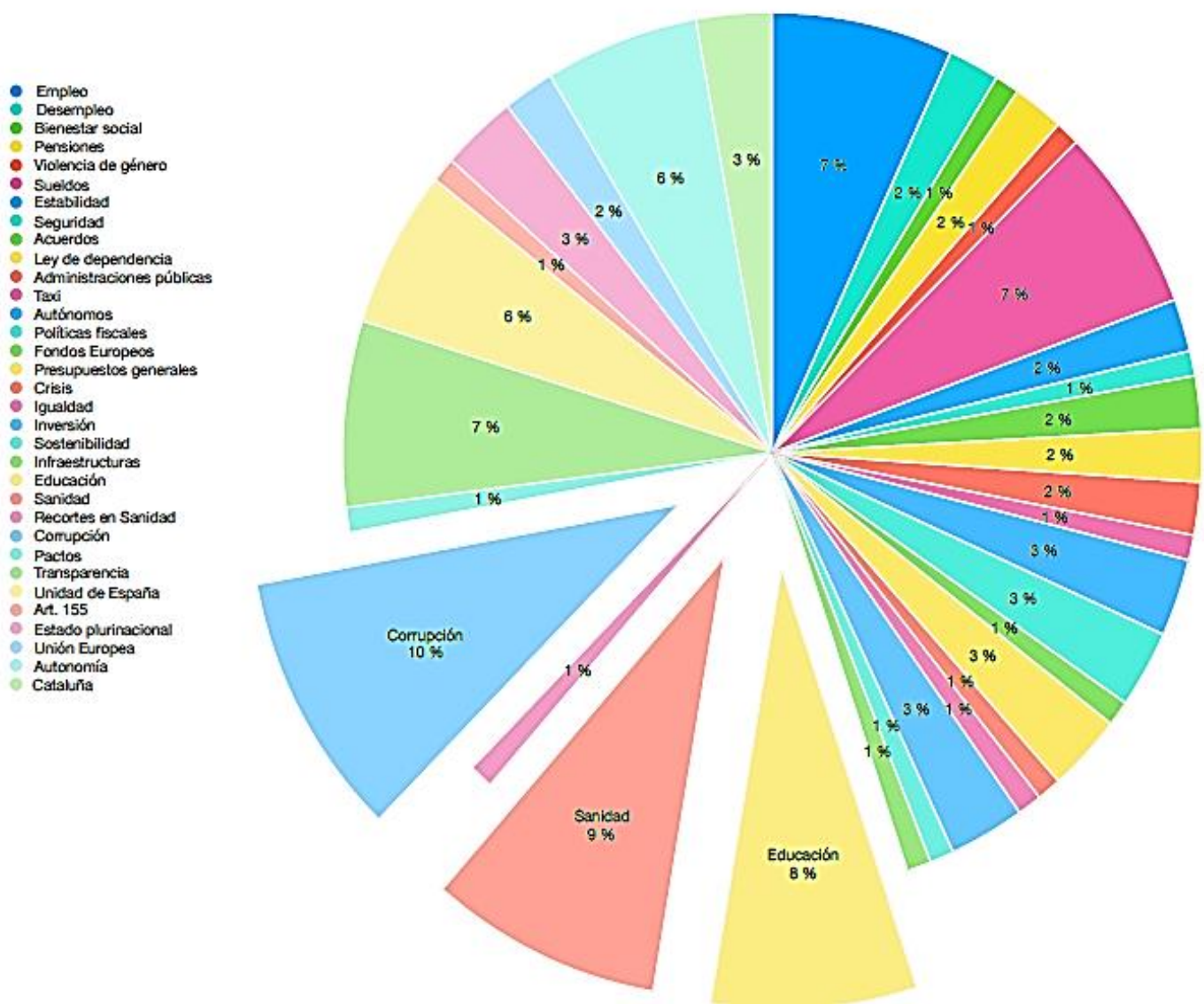

Fuente: elaboración propia

Tal y como muestra la gráfica, existe una diversificación de contenidos muy específica, que computa hasta 33 temas que afectan de forma directa o indirecta a los ciudadanos. Destacan tres núcleos que representan focos de preocupación ciudadana: la corrupción, las políticas de recorte en Sanidad y el pacto por la Educación, a los que se suma el Empleo, como tema de interés primario de la población.

Sin embargo y aunque la estructura de los debates es cerrada en cuanto al minutado de las intervenciones, los candidatos que han representado a la oposición (PP, Ciudadanos y Adelante Andalucía) marcan como destacados y dedican mayor atención a temas de actualidad que han generado conflicto y cuestionan la gestión gubernamental. 
Independencia en Cataluña, presupuestos generales, pensiones, violencia de género, políticas fiscales, autónomos o taxi, entre otros. Son, además, temas directamente relacionados con el Estado (y no con Andalucía), con importante repercusión mediática y efectos en todas las comunidades.

Los porcentajes indican también el interés por temas relacionados con el Estado (y no con Andalucía) dado que se trata de asuntos con repercusión mediática, que han calado entre los españoles y andaluces.

$\mathrm{Al}$ igual que en otros debates televisados anteriormente, se observa como cada partido --sobre todo de quienes han representado el bipartidismo-- se erige en adalid del bloque de Políticas Sociales (en el caso del PSOE) o de Políticas empresariales (en el caso del PP), utilizándolas en modo boomerang, como estrategia de campaña.

Las redes reproducen los temas debatidos con la diferencia de que no se someten a la presión del tiempo en el debate televisado; esto permite que desde las cuentas personales de cada candidato se publiquen aquellos tweets más relevantes para afianzar y viralizar el mensaje fuerza (con valencia positiva o negativa) de cara a las elecciones.

Las siguientes gráficas registran en porcentajes, los temas a los que los representantes políticos han dedicado mayor atención e interés en televisión y en Twitter.

Gráficas 4. Temas-Fuerza de Susana Díaz en TV y en Twitter
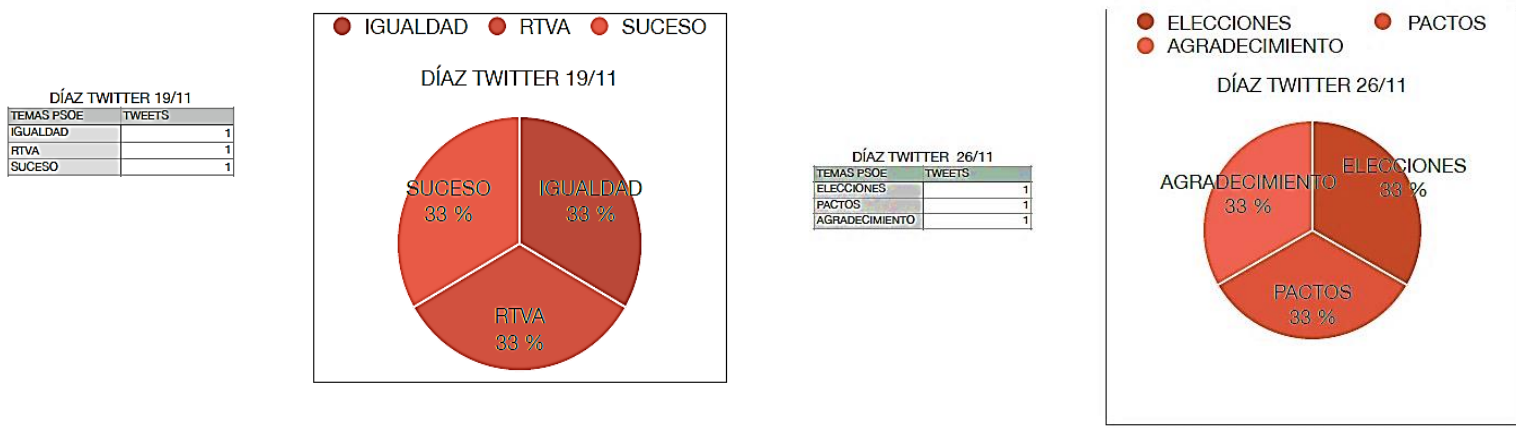

Fuente: elaboración propia 
Gráficas 5. Temas-Fuerza de Juanma Moreno en TV y en Twitter

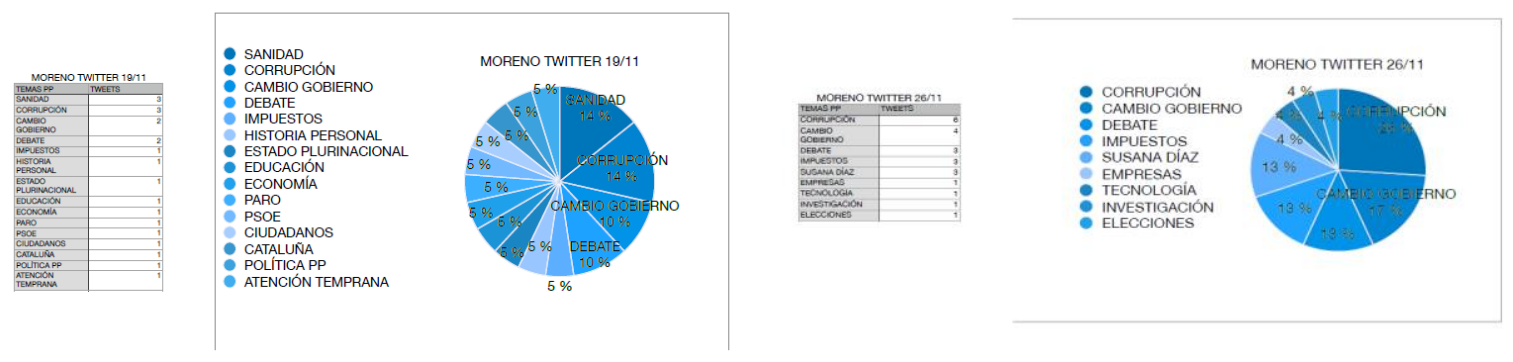

Fuente: elaboración propia

Gráficas 6. Temas- Fuerza de Juan Marín en TV y en Twitter

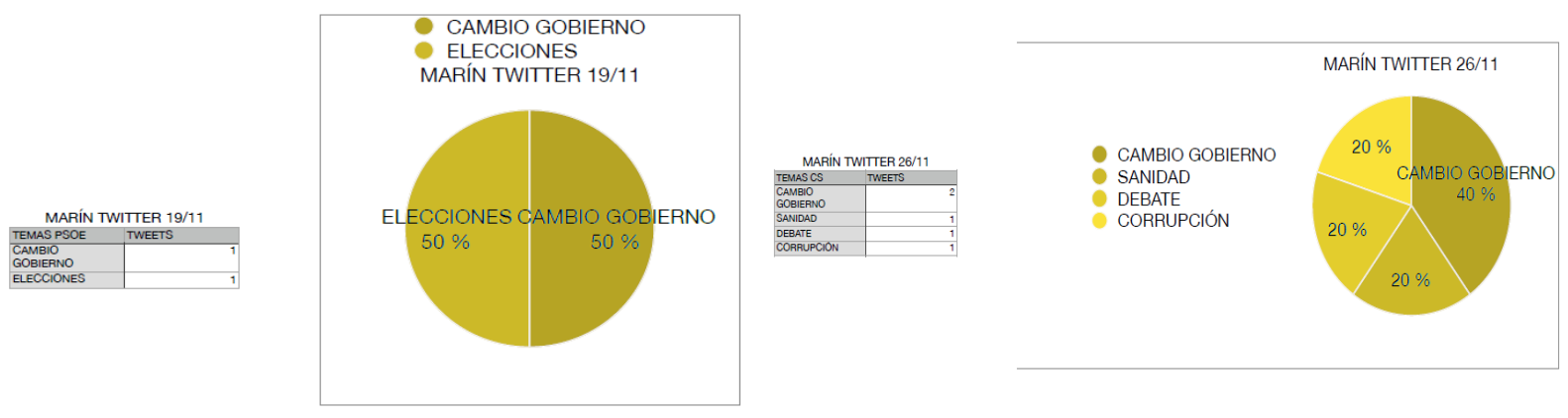

Fuente: elaboración propia

Gráficas 7. Temas- Fuerza de Teresa Rodríguez en TV y en Twitter

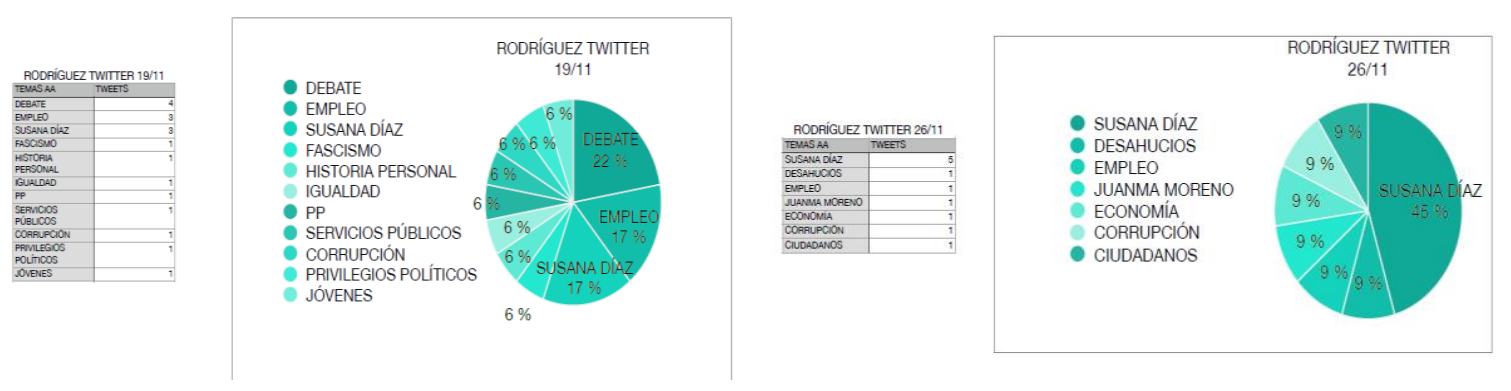

Fuente: elaboración propia 
La comparativa refleja cómo en el segundo debate (26N) adquieren relevancia los contenidos relacionados con empleo, corrupción, sanidad, educación, desahucios y otros conflictos relacionados con la gestión del Gobierno. De esta estrategia, derivan los temas estrella de esta segunda sesión: elecciones y pactos políticos.

En línea con los objetivos de la investigación, se incluyen también los temas que ha publicado Francisco Serrano, el candidato de Vox en Andalucía.

Gráfica 8. Temas-Fuerza de Vox en Twitter

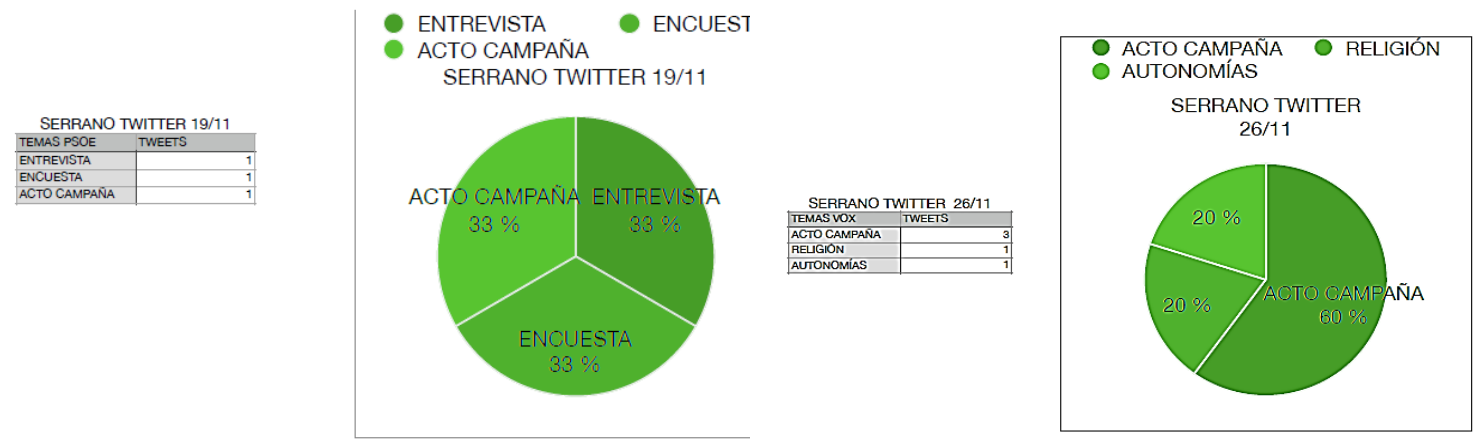

Fuente: elaboración propia

Se produce un paralelismo de los temas emitidos en TV con los difundidos en redes; los 101 tweets publicados entre debate 1 (45) y debate 2 (56) por los cinco candidatos analizados coinciden con los temas más subrayados también en el plató televisivo.

\section{c) Niveles de bidireccionalidad}

La bidireccionalidad de las redes se sustenta en la actitud y capacidad de los candidatos para usar aquellos recursos que la propia red incorpora para reforzar los caracteres mínimos con los que funcionan los mensajes digitales. Herramientas como los links (de medios de comunicación, de documentos, webs y otros), hashtags (para unificar y agrupar tweets sobre un tema común), las imágenes (fotos de los protagonistas y de su contacto con los ciudadanos), vídeos (stories propias de los candidatos, del partido, etc) y memes (para añadir el punto humano, irónico, crítico o cercano con los seguidores). La 
investigación revela que los candidatos con un seguimiento más representativo en Twitter son en este orden, Teresa Rodríguez y Juan Manuel Moreno. En concreto, la candidata de AA, realiza un uso constante, cercano, personalizado, humorístico o irónico, pero también con una elevada carga de propaganda:

Imágenes 4, 5 y 6.

Capturas de Tweets de Teresa Rodríguez (AA)
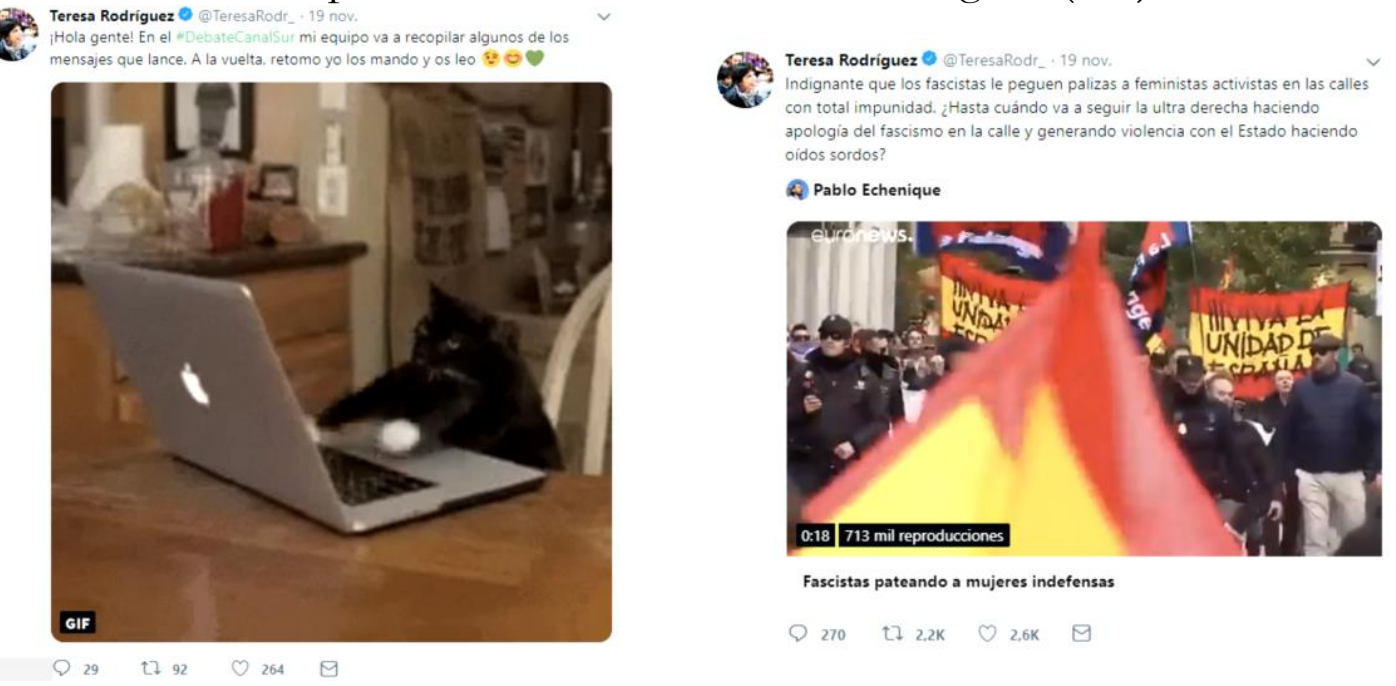

(4) Pablo Echenique

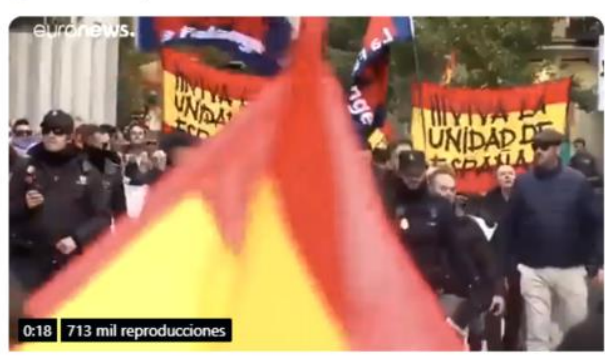

Fascistas pateando a mujeres indefensas

Q $270 \quad$ t] $2.2 \mathrm{~K} \quad \bigcirc \quad 2.6 \mathrm{~K} \quad \square$

Fuente: Twitter

Capturas de Tweets de Juanma Moreno (PP)

2. Juanma Moreno

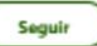

¿Por qué Marín hizo presidenta a la Sra. Díaz si representa al partido del despilfarro? ¿Por qué pidió la Sra. Díaz el archivo del caso ERE al considerar que no había delito? PSOE y Ciudadanos no han querido que los andaluces sepan la verdad.

\#DebateCanalSur

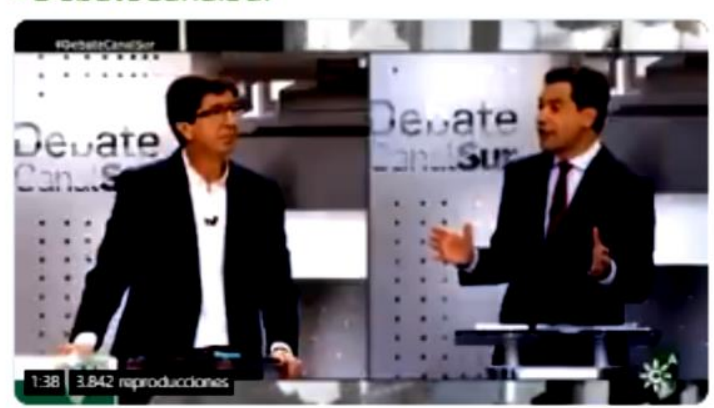

14:18 19 nov. 2018

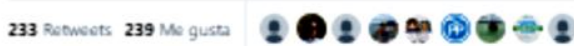

Fuente: Twitter 
Con respecto, al representante del PP, los tweets, al igual que los mensajes claves del debate se dirigen contra la gestión del PSOE en la Junta de Andalucía, presidida por Susana Díaz, pero también, contra Ciudadanos, por ser socio de gobierno. Una doble estrategia: proponer el cambio y detener en su partido la fuga de votos hacia Ciudadanos.

El resto de candidatos publica en menor proporción durante las dos sesiones de debates y alcanzan también métricas inferiores. La candidata del PSOE, sí alcanza porcentajes relevantes en comentarios y respuesta a usuarios (36\%) en Twitter durante la celebración del segundo debate.

\section{Imagen 6.}

Captura de Tweets de Susana Díaz (PSOE)

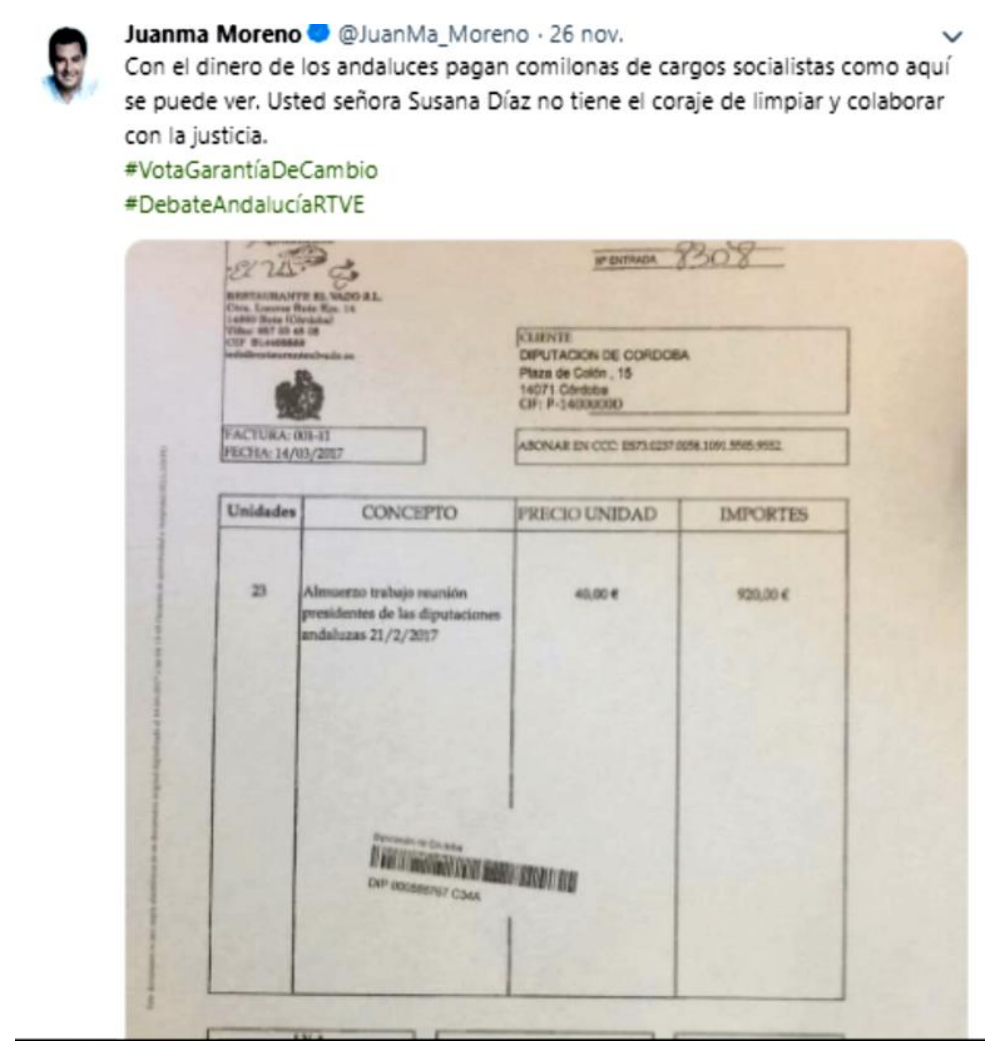

Fuente: Twitter

Las métricas totales revelan que Teresa Rodríguez, con un índice de comentarios del 63\% (19N) y del $34 \%(26 \mathrm{~N})$, en línea con el perfil del partido al que representa (Podemos), genera una relación bidireccional con los públicos de Twitter, se encarga personalmente de lanzar sus tweets, los refuerza con imágenes, vídeos, links, hashtags y memes y 
conecta con sus seguidores. Sin embargo, el resultado electoral (ocupan la cuarta posición, detrás de PSOE, PP y Ciudadanos) no es proporcional a su efectividad en redes.

\section{Conclusiones}

El sistema actual de debates políticos ha dejado de interesar a la opinión pública en general. Por tanto, se impone una reflexión por parte de los medios y del sistema político sobre la pertinencia del actual modelo que corre paralelo al debate que se produce en las redes sociales.

Por otra parte, la personalización que se ha producido en la política, alimentada en redes como Twitter, hacen que el candidato prevalezca sobre ideología y discurso, perjudicando al debate en general y el electoral en particular.

Además, es reseñable que, aunque las redes ya no son una herramienta novedosa, sigue sin hacerse un uso correcto de las mismas, alimentándose un discurso unidireccional que nada tiene que ver con la bidireccionalidad que permiten y que alentaría un debate entre candidatos y electores que rara vez se produce.

Por último, los candidatos en los "debates a cuatro" han hecho una campaña impagable al candidato del quinto partido en discordia, que no estando presente y no habiendo participado, ha sobrevolado los dos platós de televisión copando un protagonismo que no le pertenecía.

\section{Bibliografía}

Alonso-Muñoz, L. y Casero-Ripollés, A. (2019). “Communication of European populist leader on Twitter. Agenda setting and the more is less Effect.". EPI, 27 (6), 1193-1202.

Bimber, B. (2014). "Digital media in the Obama campaigns of 2008 and 2012: Adaptation to the personalized political 
communication environment". Journal of Information Technology \& Politics, 11 (2), 130-150.

Canel, M. (2008). "Debatir para ganar". Nueva Revista de Política, Culturay Arte, 115, 21-27.

Carrasco-Polaino, R., Villar-Cirujano, E., Tejedor-Fuentes, L. (2018.) "Twitter como herramienta de comunicación política en el contexto del referéndum independentista catalán: asociaciones ciudadanas frente a instituciones públicas". Icono 14, 16 (1), 64-85.

Casado Ruiz, A. (2012). Debates electorales en televisión: nuevos contenidos para nuevos formatos. Actas del III Congrés Internacional Associació Espanyola d'Investigació de la Comunicació.

Coller, X. (2019). "La extrema derecha ya está aquí: ¿Hasta dónde puede llegar Vox?”. Disponible en: https://www.huffingtonpost.es/2018/10/07/la-extremaderecha-ya-esta-aqui-hasta-donde-puede-llegarvox_a_23552333/

Druckman, J. (2003). "The Power of Television Images: The First Kennedy-Nixon Debate Revisited". The Journal of Politics, 65 (2), 559-571.

Engesser, S., Fawzi, N. y Larsson, A. (2017). "Populist online communication: Introduction to the special issue". Information, Communication \& Society, 20 (9), 1279-1292.

Gainous, J, y Wagner, K. M. (2014). Tweeting to power: The social media revolution in American politics. London: Oxford University Press.

Galindo Arranz, F. y Regueira Rey, J. C. (2018). “Cobertura informativa de procesos electorales: innovación y oportunidad de un servicio público esencial". En RodríguezCastro, M., Pérez-Seijo, S. y Campos-Freire, F. (eds.), La TV Pública en Europa: Innovación, Retos y Tendencias. Cuadernos Artesanos de Comunicación, 146, 89-109. La Laguna (Tenerife). Jackson, N. y Lilleker, D. (2011). "Microblogging, constituency service and impression management: UK MPs and the use of Twitter". The journal of legislative studies, 17 (1), 86-105.

López-Meri, A., Marcos-García, S. y Casero-Ripollés, A. (2017). "What do politicians do on Twitter? Functions and 
communication strategies in the Spanish electoral campaing of 2016”. EPI, 26 (5), 795-804.

Pérez-Curiel, C. y Lancharro, I. (2017). "Las estrategias de comunicación de Podemos y Ciudadanos en los debates electorales. Una aproximación mediante análisis de contenido: el debate de Atresmedia TV como estudio de caso". Razón y Palabra, 21 (4).

Pérez-Curiel, C. (2019). "Vox y voto: shock en Andalucía". Disponible en: http:// theconversation.com/vox-y-votoshock-en-andalucia-109519.

Pérez-Curiel, C. y Limón Naharro, P. (2019). Influencers de la Política. Estudio de la marca personal de Donald Trump en Twitter y efectos en medios y usuarios. Communication \& Society, 32(1), 57-76.

Pérez-Curiel, C. y García-Gordillo, M. (2018). "Política de influencia y tendencia fake en Twitter. Efectos postelectorales (21D) en el marco del Procés en Cataluña”. EPI, 27 (5), 1030-1040.

Rodríguez Sáez, A. (2018). "El populismo de intruso a problema relevante para la ciencia social". Revista Internacional de Sociología 76(4).

Rúas Araújo, X., Mazaira, A. y Rodríguez Vázquez, A. (2018). "Nuevos medios y medios tradicionales en la red. Espacios de opinión e interacción política en la era Trump". Icono 14, 16(1), 86-113.

Salvador i Liern, V. (2008). "Palabra y cultura del debate: reflexiones sobre el debate político español”. En María Luisa Villanueva Alfonso, (dir.), El Mediterráneo y la cultura del diálogo. Lugares de encuentro y de memoria de los europeos, Universidad Jaime I, Castellón de la Plana, 25-48.

Vergeer, M., Hermans, L. y Sams, S. (2013). “Online social networks and micro-blogging in political cam- paigning: The exploration of a new campaign tool and a new campaign style". Party politics, 19 (3), 477-501.

\section{Agradecimientos}

Grupo de Investigación Communication \& Social Sciences (SEJ-619). 
Equipo de Análisis Estadístico de Periodismo Político. Facultad de Comunicación, Universidad de Sevilla. Coordinador: Rubén González Caamaño. Miembros: Tania Casas, María Ángeles González, Miguel Rodríguez, Alejandro Rojas y Alejandro Romero. 


\section{I \\ Los autores y las autoras}

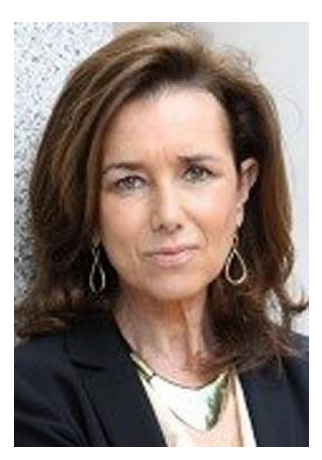

ANAYA-REVUELTA, INMACULADA

Universidade de Vigo

ianaya@,uvigo.es

Doctora en Filología y Premio Extraordinario de Doctorado por la Universidad Complutense de Madrid. Profesora Titular de Lengua Española en la Universidade de Vigo desde 1999. Participa en el proyecto "Debates electorales televisados en España: modelos, proceso, diagnóstico y respuesta", financiado por el Ministerio de Economía, Industria y Competitividad

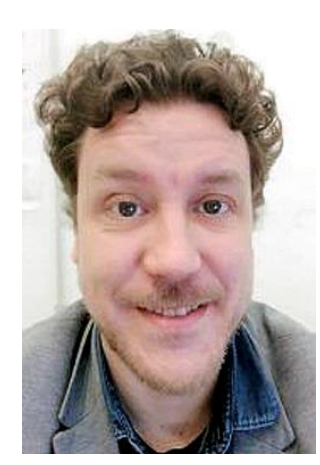

CASTROMIL, ANTÓN R.

Universidad Complutense de Madrid arcastromil@,ccinf.ucm.es

Es profesor de Opinión Pública y Sociología en el Departamento Sociología Aplicada de la Universidad Complutense de Madrid. Sus principales líneas de investigación se centran en el estudio de los efectos políticos de los medios de comunicación en el seno de las democracias representativas. 


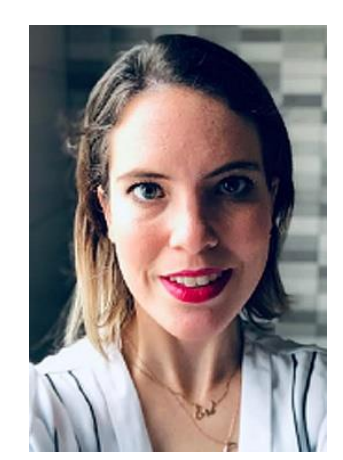

\section{CONDE-VÁZQUEZ, ERICA}

Universidade de Vigo

erikaconde@,uvigo.es

Graduada en Publicidad y Relaciones Públicas en la Universidade de Vigo, Máster en Marketing, Consultoría y comunicación política. Actualmente Doctoranda en la Universidade de Vigo en el proyecto de I+D+I (Retos) "DEBATv, Debates Electorales Televisados en España: Modelos, Proceso, Diagnostico y Propuesta" (Ref. CSO201783159-R), financiado por el Ministerio de Economía, Industria y Competitividad (MINECO), la Agencia Estatal de Investigación (AEI) y el Fondo Europeo de Desarrollo Regional (FEDER) de la Unión Europea (UE).

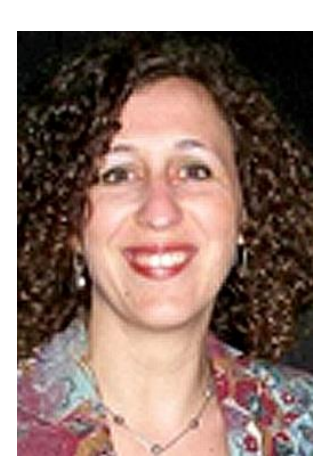

\section{FERNÁNDEZ-SOUTO, ANA B.}

Universidade de Vigo

abfsouto@uvigo.es

Profesora Titular de Universidad en el Departamento de Comunicación Audiovisual y Publicidad, Facultad de Ciencias Sociales y de la Comunicación, Universidade de Vigo (España). Profesora invitada en distintas universidades americanas y europeas, como la Universidad Dámaso Alonso Larrañaga (Montevideo, Uruguay), Universidade de Minas Gerais (Belo Horizonte, Brasil), Universidad Autónoma de Querétaro (Querétaro, México); Universidad Nacional Autónoma de México, UNAM (México); Universidad de Costa Rica (San José, Costa Rica);

Universidad del Norte de Chile (Antofagasta, Chile); Universidad de Dubrovnik, (Dubrovnik, Croacia); Universidade Fernando Pessoa (Porto, Portugal); Universidade de Minho (Braga, Portugal), la Lumsa Universita (Roma, Italia) o Universidade de Açores (Portugal). Sus líneas principales de investigación son la Comunicación Organizacional, Relaciones Públicas y Comunicación Política.ORCID: orcid.org/0000-0003-2685-0604 


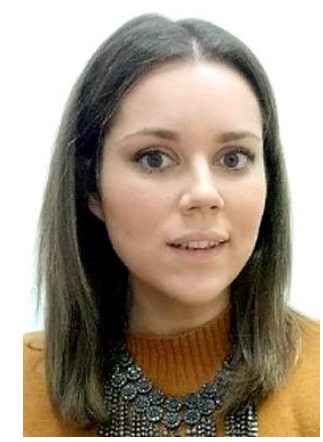

\section{FONTENLA-PEDREIRA, JULIA}

Universidade de Vigo

julia.fontenla.pedreira@,uvigo.es

Licenciada, en Periodismo por la Universidad de Santiago de Compostela, y Máster en Lengua y Comunicación en los Negocios por la Universidade de

Vigo. Especialista en las áreas de comunicación corporativa e institucional, actualmente es doctoranda en el programa Creatividad e Innovación Social, y docente en la Universidade de Vigo.

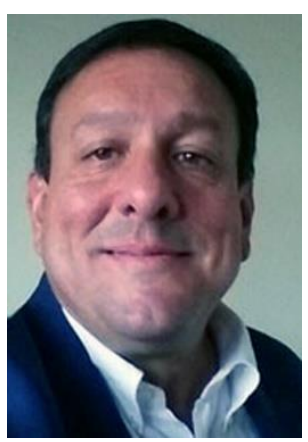

\section{GALINDO-ARRANZ, FERMÍN}

Universidad de Santiago de Compostela fermin.galindo@usc.es

Fermín Galindo es Doctor en Ciencias de la Información por la Universidad del País Vasco (1992) y Profesor Titular de Periodismo de la Universidad de Santiago de Compostela. Universidad en la que participa de forma estable en el Master en Marketing y Comunicación Política de la Facultad de Ciencias Políticas y de la Administración de la USC. Ha publicado numerosos libros y trabajos sobre el tema, entre ellos: Fundamentos de Comunicación Politica (1998), A Comunicación Politica Hoxe (1999), Ámbitos del Periodismo de Precisión (2004) y Las notas de la prensa (2010) y Siete Picas. Entre la Ciencia y el Periodismo (2016). En la actualidad imparte las materias Métodos de Investigación en Comunicación y Géneros Interpretativos y de Opinión.

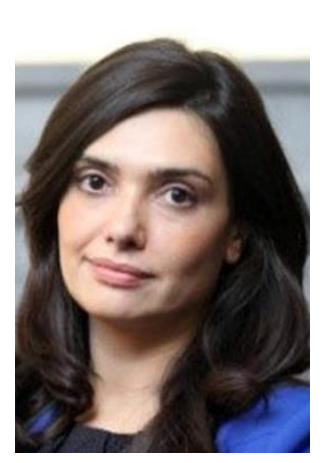

\section{GALLEGO-REGUERA, MARÍA}

Centro de Educación Superior Next- Universitat de Lleida

maria.gallego@,cesnext.com

Doctora en Ciencias de la Información y Licenciada en Periodismo. Experta en comunicación política e institucional. Ha publicado varios libros y artículos sobre debates electores y ha participado en la organización de los debates entre candidatos a la presidencia del Gobierno en España en 
las elecciones generales de 2008, 2011, 2015 y 2016 como miembro de la Academia de las Ciencias y las Artes de Televisión. Profesora de comunicación en Universidad Internacional Menéndez Pelayo, Universidad de Salamanca y Universitat de Lleida, entre otras. Además, ha ejercido profesionalmente en varios medios como periodista.

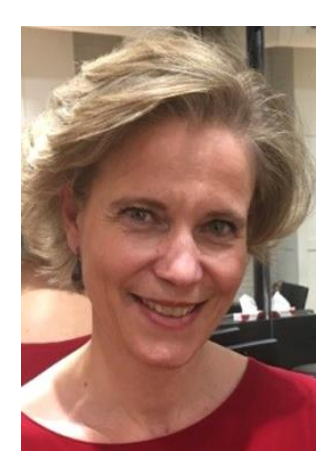

\section{GARCÍA-GORDILLO, MAR}

Universidad de Sevilla

marggordillo@,us.es

Profesora Titular del Departamento de Periodismo II de la Universidad de Sevilla. Miembro del Grupo de Investigación SEJ-619 Communication \& Social Sciences (COM \& SOC). Actualmente es Directora General de Comunicación de la Universidad de Sevilla y anteriormente ha ejercido como Vicedecana de Prácticas y Empresas de la Facultad de Comunicación y como Directora del Secretariado de Prácticas en Empresas y Empleo de la Universidad.

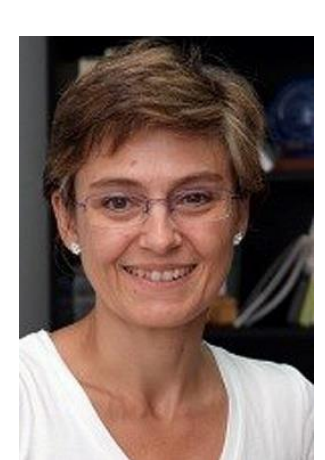

\section{LEGERÉN, BEATRIZ}

Universidade de Vigo

blegeren@uvigo.es

Profesora en la Facultad de Comunicación y Ciencias Sociales de la Universidade de Vigo, Investigadora especializada en el ámbito de los Games Studies. Autora de diferentes artículos y capítulos de libros centrados en el diseño de juegos entendiendo diseño como el momento de concepción de un producto que necesita para su construcción, reglas, mecánicas, tecnología y narración. http://orcid.org/0000-0001$\underline{6169-0875}$ 


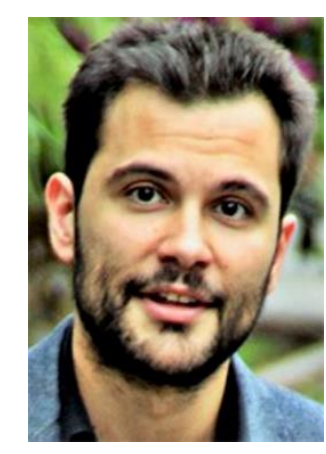

\section{LÓPEZ-LÓPEZ, PAULO CARLOS}

Pontificia Universidad Católica de Ecuador Sede Ibarra

pclopez@pucesi.edu.ec

Doctor en Comunicación e Industrias Creativas por la Universidad de Santiago de Compostela (2016) y docente-investigador en la Carrera de Comunicación en la Pontificia Universidad Católica del Ecuador Sede Ibarra (Ecuador), en asignaturas como Pensamiento Sociopolítico y Opinión Pública, Derecho de la Información o Información Periodística Especializada. Posee el Diploma de Estudios Avanzados en el Programa de Doctorado Comunicación y Periodismo de la USC (20072009).

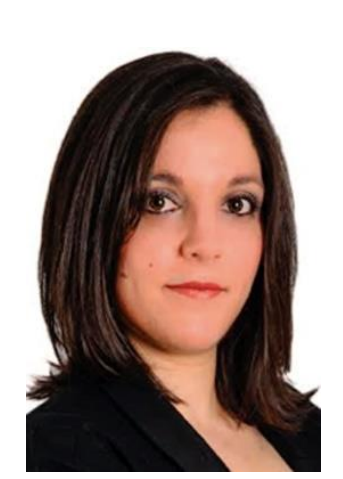

\section{LÓPEZ-MARCOS, CASANDRA}

CES Next- Universitat de Lleida

casandra.lm@gmail.com

Licenciada en Periodismo (2011), Máster de Investigación Aplicada a la Comunicación (2012) y doctora en Comunicación con mención europea, sobresaliente cum laude y premio extraordinario de doctorado (2016). Actualmente está trabajando en CES Next, centro adscrito a la Universitat de Lleida.

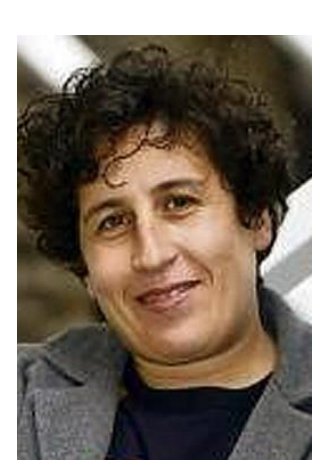

\section{MARTÍNEZ-MARTÍNEZ, ISABEL}

Universidade de Vigo

isabelmartinez@uvigo.es

Doctora en Comunicación Audiovisual y en Publicidad y Relaciones Públicas por la Universidade de Vigo. Productora del largometraje Arraianos (2012) de Eloy Enciso, estrenado en Locarno, y programado en más de veinte festivales internacionales, donde obtiene el reconocimiento del jurado en BAFICI, FICUNAM, Festival Europeo de Sevilla o Cinema D‘Autor de Barcelona. 


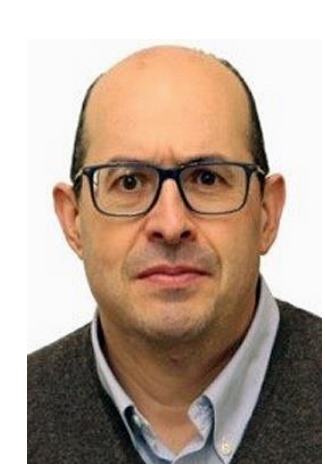

\section{MAZAIRA-CASTRO, ANDRÉS}

Universidade de Vigo

amazaira@,uvigo.es

Profesor contratado doctor del Departamento de Organización de Empresas y Marketing en la Universidade de Vigo y fue vicerrector de su campus de Ourense. Dedica la mayor parte de su trabajo profesional a explicar, analizar e investigar el uso intensivo y extensivo de internet y los cambios derivados de la transformación digital en los consumidores, los mercados, los modelos de negocio y la política.

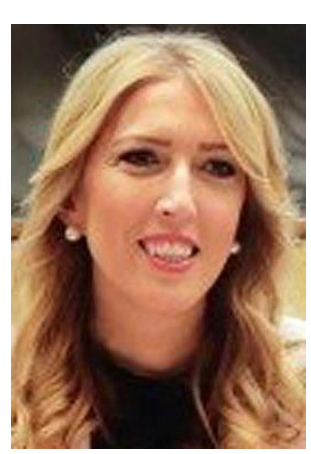

\section{MICOVIC, MILJANA \\ CES Next- Universitat de Lleida \\ miljanamic@gmail.com}

Es doctora en Comunicación Política y Lengua Española y Máster en Experto en Español Lengua Extranjera en Ámbitos Profesionales por la Universitat de Barcelona. Licenciada en Filología Hispánica por la Universidad de Belgrado (Serbia). Actualmente, es Coordinadora Académica de Next International.

Business School, profesora de debate, discurso político y público en el Máster en Comunicación Política Avanzada del Centro de Educación Superior Next, Posgrado en Comunicación Institucional y Posgrado en Reforma Organizacional de Next IBS.

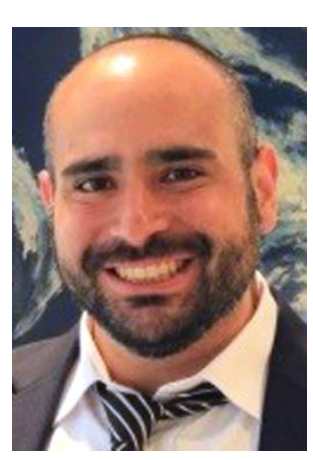

\section{NUÑEZ-MUSSA, ENRIQUE}

Pontificia Universidad Católica de Chile nunezmussa@gmail.com

Académico en la Facultad de Comunicaciones de la Pontificia Universidad Católica, donde enseña e investiga análisis de actualidad política, fact checking, escritura y edición en medios periodísticos. Magíster en

Periodismo, Medios y Globalización con una especialización en Culturas Periodísticas. 


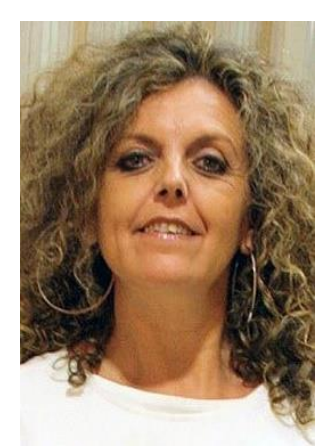

\section{PÉREZ-CURIEL, CONCHA}

Universidad de Sevilla

cperezl@,us.es

Profesora de la Universidad de Sevilla y miembro del grupo de investigación Communication \& Social Sciences (SEJ-619). Centra su línea investigadora en

Periodismo Político, Comunicación y Marketing Político, Análisis de Contenido e Investigación en Moda. Imparte docencia en el Máster en Comunicación Institucional y Política (US), en el Máster en Dirección de Marketing (Loyola) y es directora del Máster en Comunicación y Moda de la Universidad de Sevilla.

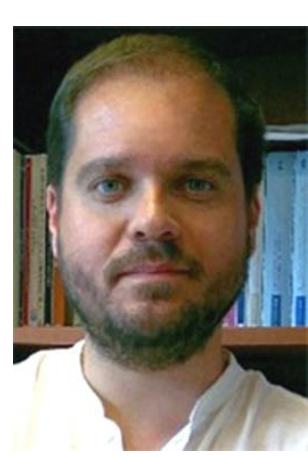

\section{PUENTES-RIVERA, IVÁN}

Universidad de A Coruña

i.puentes@udc.es

Profesor en el Departamento de Sociología y Ciencias de la Comunicación de la Universidad de A Coruña. Licenciado en Publicidad y Relaciones Públicas, Máster en investigación en Comunicación y Doctor en Comunicación por la Universidade de Vigo en la que es miembro del grupo de investigación CP2, además de investigador vinculado a la red Internacional de Investigación de la gestión de comunicación (XESCOM). Autor de diferentes artículos y trabajos sobre relaciones públicas, transparencia y comunicación política. Ha realizado estancias de docencia en diversas universidades portuguesas y ecuatorianas y posee una variada experiencia profesional en el ámbito de la gestión de la comunicación política y electoral.

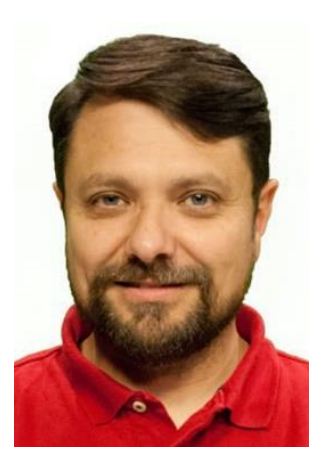

\section{REGUEIRA-REY, JUAN CARLOS}

CRTVG

carlos.regueira@gmail.com

Trabaja en la producción audiovisual desde 1988 en la Televisión de Galicia. Desde 2007, ha sido productor de los especiales emitidos por el canal autonómico con ocasión de los comicios locales, autonómicos, estatales 
y europeos. Licenciado en Comunicación Audiovisual por la Universidade de Vigo (2007), es co-autor del primer trabajo de investigación financiado por la AGADIC (Axencia Galega das Industrias Musicais) sobre las orquestas de verbena de Galicia. Ha sido profesor asociado de la USC y co-director del primer Master en Industria Musical de la USC. Su principal línea de investigación se sitúa en la intersección entre los media studies y la música popular, eje de su tesis doctoral.

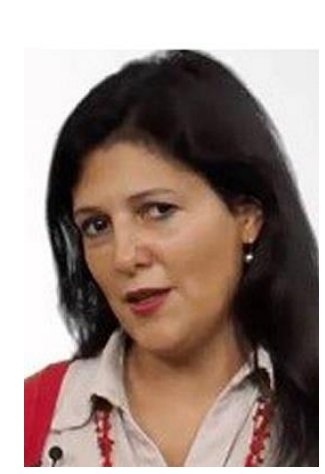

\section{RODRÍGUEZ-RODRÍGUEZ, RAQUEL}

Universidad Rey Juan Carlos

raquel.rodriguez@urjc.es

Es doctora y licenciada en Ciencias de la Información por la Universidad Complutense de Madrid con estudios de tercer ciclo en la Universidad degli Studi di Trento, Universidad of Texas at Austin y Harvard University. Ha trabajado en la Universidad Complutense, en la Universidad Nacional de Educación a Distancia (UNED) y actualmente es profesora en la Facultad de Ciencias de la Comunicación de la Universidad Rey Juan Carlos de Madrid.

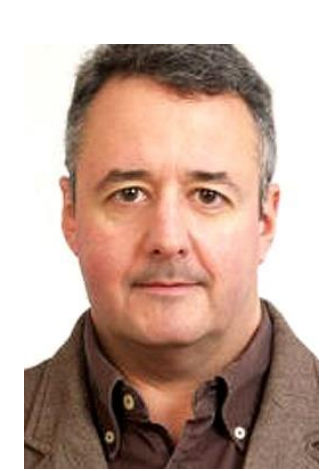

\section{RÚAS-ARAÚJO, JOSÉ}

Universidade de Vigo

xoseruas@uvigo.es

Profesor de Comunicación Política de la Facultad de Ciencias Sociales y de la Comunicación de la Universidade de Vigo y director de su Departamento de Comunicación Audiovisual y Publicidad. Es investigador principal del proyecto de I+D+I (Retos) "DEBATv, Debates Electorales Televisados en España: Modelos, Proceso, Diagnostico y Propuesta" (Ref. CSO2017-83159-R), financiado por el Ministerio de Economía, Industria y Competitividad (MINECO), la Agencia Estatal de Investigación (AEI) y el Fondo Europeo de Desarrollo Regional (FEDER) de la Unión Europea (UE). 


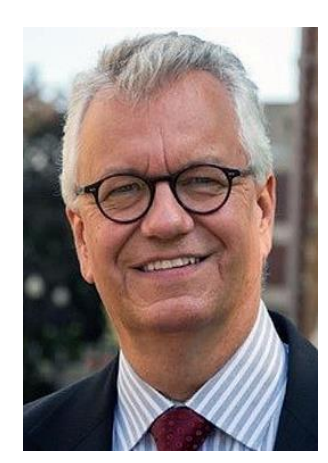

\section{SCHROEDER, ALAN}

Northeastern University of Boston

alandschroeder@,comcast.net

Profesor emérito en la Escuela de Periodismo de la Northeastern University (Boston, Massachusetts USA), con especialización en la relación entre la política y los medios de comunicación en Estados Unidos e internacionalmente. Schroeder es autor de los libros Presidential Debates: Risky Business on the Campaign Trail y Celebrity-in-Chief: How Show Business Took Over the White House. Los artículos de Schroeder se han publicado en el New York Times, Financial Times, $W$ ashington Post, Boston Globe, Politico, (U.K.) Guardian, y Huffington Post. Como comentarista, Schroeder ha dado entrevistas en muchas cadenas de televisión y radio, incluso CNN, ABC, BBC, CBS, C-SPAN, MSNBC, Fox News, National Public Radio, Sky News (Reino Unido), Canadian Broadcasting Company, Australian Broadcasting Company, y RTE (España).

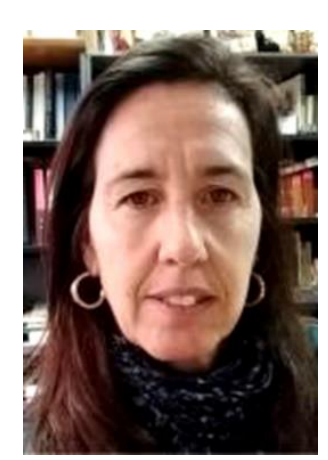

\section{VÁZQUEZ-GESTAL, MONTSE}

Universidade de Vigo

mvgestal@uvigo.es

Profesora invitada en diversas universidades internacionales: Universidad Autónoma de Querétaro y Universidad Nacional Autónoma de México (México, 2001); Universidad de Dubrovnik (Croacia, 2006), Universidade Fernando Pessoa (Portugal, 2008); Universidade do Minho (Portugal, 2009); LUMSA Universitá De Roma (Italia, 2006 - 2009); La Sapienza, Roma (Italia, 2011). Profesora Titular de Universidad en la Universidade de Vigo, docente de las materias Creatividad Publicitaria y Estrategias de la Comunicación Publicitaria. Investigadora Principal del grupo I+D de la Universidade de Vigo CP2: Comunicación Persuasiva. 